\title{
Diálogo entre as Artes Plásticas e a Publicidade no Brasil
}

Tese apresentada à Área de Concentração: Artes Plásticas da Escola de Comunicações e Artes da Universidade de São Paulo, como exigência parcial para obtenção do Título de Doutor em Artes, sob a orientação da Prof ${ }^{a}$ $D r^{a}$ Annateresa Fabris. 


\section{Diálogo entre as Artes Plásticas e a Publicidade no Brasil}

Tese apresentada à Área de Concentração: Artes Plásticas da Escola de Comunicações e Artes da Universidade de São Paulo, como exigência parcial para obtenção do Título de Doutor em Artes, sob a orientação da Prof ${ }^{a}$ $D r^{a}$ Annateresa Fabris. 
Tese defendida em de de , perante

a seguinte comissão julgadora:

Presidente 
AOS MEUS PAIS 


\section{AGRADECI MENTOS}

Um agradecimento especial à professora Annateresa Fabris, por ter me aproximado do assunto desta tese. Pela sua orientação neste e em outros projetos que ocorreram e nos quais sempre presenciei uma conduta ética e uma clareza mental pouco comum. E, aproveito para me desculpar por não ter conseguido ir mais longe.

As professoras Lisbeth Rebollo Gonçalves e Ana Paula Cavalcanti Simioni, pelas contribuições intelectuais decorrentes do exame de qualificação.

Ainda a Ana Paula e a Priscila Rossinetti Rufinoni manifesto minha gratidão por aquelas dicas mágicas e pelos apoios e incentivos fraternos, que sempre nos são necessários.

Aos meus irmãos Luiz e J osé Carlos, pelas ajudas experientes.

Um agradecimento particular à Beatriz, por mais uma vez ter esperado tanto... E, me desculpo pelas nossas conversas tão sérias, pelas muitas brincadeiras adiadas e risadas que não pudemos compartilhar.

Aos alunos, amigos e direção da Escola de Artes César Antonio Salvi, agradeço o modo tão generoso com que souberam compreender a necessidade do meu breve afastamento das aulas.

Ao Instituto Moreira Salles pela oportunidade em pesquisar e participar do projeto Os "reclames" de Fulvio Pennacchi: primórdios da propaganda brasileira.

Ao CAPES pela concessão de Bolsa de Estudo durante o período de março de 2003 a março de 2004.

São Paulo, junho de 2007. 


\section{Resumo: Diálogo entre as Artes Plásti Cas e a Publicidade no Brasil}

PALAVRAS-Chaves: publicidade, reclames, anúncios comerciais, arte moderna, arte brasileira, cartazes, artes gráficas, artistas plásticos, hierarquias artísticas, poetas.

A participação dos artistas plásticos e gráficos na publicidade brasileira, mais especificamente na comercial de produtos e empreendimentos, entre as décadas de 1920-1940 constitui o núcleo de investigação desta tese.

Se historicamente as artes plásticas e a publicidade internacionais sempre mantiveram relações estreitas e até mesmo conflituosas, indagou-se como teriam se comportado entre si esses dois campos profissionais no Brasil quando da passagem da nossa publicidade amadora para aquela moderna, impregnada, sobretudo, pelos métodos das agências norte-americanas atuantes no eixo RioSão Paulo.

A partir de um exame atento do mercado de trabalho dos diversos profissionais considerados, procurou-se entender as motivações que os levaram a produzir peças publicitárias, o que por sua vez direcionou o estudo ao questionamento das hierarquias artísticas, pois a relação entre a arte e a publicidade prolonga 0 consagrado debate em torno das artes mecânicas e liberais, e, por conseguinte as disputas entre arte maior e arte menor, entre arte pura, desinteressada e livre e arte comprometida, dentre outras tipologias usuais. Concomitantemente, averigou-se como a passagem e mesmo a convivência de um sistema acadêmico com um moderno, que se constituiu a partir dos anos 1920, alterou, ou melhor, conformou o campo artístico brasileiro.

Frente a esses impasses, recorreu-se a algumas proposições teóricas mais atuais, que ao transferirem o foco problemático do campo artístico para 0 estético, atenuaram os questionamentos como também permitiram maior flexibilidade de análises.

Nos exames formais das peças publicitárias, selecionadas em função de suas representatividades dentro do conjunto, defendeu-se a tese de que houve 
momentos em que a produção de cartazes e anúncios comerciais, este em maior número, aproximou-se de uma linguagem artística moderna, a exemplo dos projetos comerciais do artista Fulvio Pennacchi, que pertencem à coleção do Instituto Moreira Salles. E, na busca desses momentos estéticos modernos, procurou-se não enxertar e tão somente verificar correspondências com os moldes europeus, ao contrário, isso permitiu o conhecimento da nossa realidade, da modernidade artística que nos foi possível edificar, tendo em conta as variantes que o decorrer dos anos Ihe agregou. Este posicionamento, em contrapartida, de forma alguma pôde desprezar o fato da história da propaganda brasileira ter fortes e ricas ligações com os modelos estrangeiros, portanto, impôs-se às análises iconográficas a tarefa de também investigar o quanto a nossa produção foi ou não uma reelaboração particular dos exemplos da arte publicitária em circulação.

A interdisciplinaridade foi uma constante neste estudo pelo entrelaçamento de informações originárias de vários campos do conhecimento, sem a qual a pesquisa não teria êxito. 


\section{Abstract: Dialogue between the Plastic Arts and the Advertising in BRAZI L}

KEYWORDS: advertising, advertisement, ads, commercial advertisements, modern art, Brazilian art, posters, graphical arts, plastic artists, artistic hierarchies, poets.

The role of the plastic and graphical artists in the Brazilian commercial advertising of products and enterprises, between the decades of 1920 and 1940 , is the core of investigation of this thesis.

Historically, plastic arts and advertising always kept narrow and even tough relationships in the international panorama. Therefore, in this work we have inquired the behavior of these two professional fields in Brazil as we pass from an amateur to a modern advertising. The latter has been influenced by the North-American advertising agencies from Rio de J aneiro and São Paulo.

From a painstaking analysis of the labor market of several professionals in the plastic arts field, we have tried to understand the reasons that had taken them to produce advertisement materials. This has led us to investigate artistic hierarchies, since the relationship between art and advertising only emphasizes the old debate around mechanical and liberal arts, minor and major arts, pure and compromised arts, amongst other usual typologies. At the same time we investigated how the coexistence of an academic system and a modern one, established in the years of 1920, molded the Brazilian artistic field.

Due to these impasses it was necessary to use some modern theoretical propositions that shifted the subject from the artistic to the aesthetic field, reducing doubts and allowing for a more flexible analysis.

In the critical analysis of the selected advertisement materials, we looked for instances where the posters and commercial advertisements, the latter bigger in number, approached a more modern artistic language, such as the commercial projects of the artist Fulvio Pennacchi, that belong to the collection of the Instituto Moreira Salles. In pursuit of these modern aesthetic instances we have 
not tried only to find similarities with the European patterns but made an effort to understand our reality and the artistic modernity we were able to produce at that time. We did not deny the strong link between the Brazilian and the international advertising, therefore, in our iconographic analysis, we have investigated to what degree our advertisement productions were just reelaborations of the current advertisement art in circulation.

In this thesis the interdisciplinarity played a major role due to the crossing of information from many areas of knowledge and, without it, our research would not be possible. 


\section{Abrevi ações}

AIBA Academia Imperial de Belas Artes

ENBA/RJ Escola Nacional de Belas Artes do Rio de Janeiro

ESDI Escola Superior de Desenho Industrial

ESPM Escola Superior de Propaganda e Marketing

FAU/USP Faculdade de Arquitetura e Urbanismo da Universidade de São Paulo

LAO/RJ Liceu de Artes e Ofícios do Rio de Janeiro

LAO/SP Liceu de Artes e Ofícios de São Paulo

MARGS Museu de Arte do Rio Grande do Sul Ado Malagoli

MASP Museu de Arte de São Paulo Assis Chateaubriand

SEMTA Serviço Especial de Mobilização de Trabalhadores para a Amazônia

UFRGS Universidade Federal do Rio Grande do Sul

USP Universidade de São Paulo 
SUMÁRIO

PARTE I

INTRODUÇÃO

\section{CAPÍtUlo 1}

Do RECLAME À PUBLICIDADE

1.1 PROPAgANDA BRASILEIRA NOS ANOS 1920-40 3-18

$\begin{array}{lr}\text { 1.1.1 EVOLUÇÃO DOS ANÚNCIOS COMERCIAIS } & \text { 19-25 }\end{array}$

\section{CAPítulo 2}

Mercado de Trabalho

26-103

2.1 COMPOSIÇÕES ENTRE O LÁPIS E A PENA NA PROPAGANDA BRASILEIRA

$28-42$

2.2 ESTUDO DE CASO: REVISTA Do GLOBO

43-53

2.3 HiERARQUIAS ARTÍSTICAS: ARTES MAIORES X ARTES MENORES

$54-68$

2.4 IDEOLOGIAS ARTÍSTICAS

69-74

2.5 CONTRIBUIÇÃO DOS DIVERSOS PROFISSIONAIS DAS ARTES PLÁSTICAS NA PUBLICIDADE COMERCIAL BRASILEIRA

75-99

2.5.1 DAS PASSAGENS DOS ARTISTAS PLÁSTICOS

75-85

2.5.2 DOS ARTISTAS COMO EMPRESÁRIOS

86-87

2.5.3 DOS CARICATURISTAS E ILUSTRADORES QUE MARCARAM ÉPOCA

88-94

2.5.4 DOS ARTISTAS PUBLICITÁRIOS

95-99

2.6 CONSIDERAÇÕES FINAIS

100-103 


\section{CAPÍtUlo 3}

AnÁlise Crítica

104-162

3.1 DA CARICATURA À ILUSTRAÇÃO: A PRODUÇÃO DOS DESENHISTAS

DE IMPRENSA NOS RECLAMES

106-108

3.1.1 CARICATURISTAS E CARICATURAS COMERCIAIS

109-116

3.1.2 CARICATURISTAS NA ILUSTRAÇÃO COMERCIAL

$117-120$

3.1.3 HERDEIROS DO TRAÇO

121-126

3.2 INCURSÕES PELAS LETRAS E IMAGENS

127-135

3.3 DO RECLAME AO CARTAZ PUBLICITÁRIO MODERNO

136-138

3.3.1 CONTRIBUIÇÕES DOS ARTISTAS PLÁSTICOS NOS ANÚNCIOS COMERCIAIS

139-143

3.3.2 DO CARTAZ COMERCIAL ARTÍSTICO:

UMBERTO DELlA LATTA E ELISEU VISCONTI

144-147

3.3.3 CARTAZETES PUBLICITÁRIOS PENNACCHIANOS (1929-1932)

$148-157$

3.3.4 O MODERNO NOS ANÚNCIOS E CARTAZES COMERCIAIS PUBLICITÁRIOS:

BARÃO PUTTKAMER, ERICO E ORTHOF

158-162

CONCLUSÃo

$163-170$

BIBLIOGRAFIA

$171-191$

APÊNDICE

192-208

Anexos

$209-215$

\section{PARTE II}

\section{CATÁlogo DE IMAGENS}


I NTRODUÇÃO 
La publicité est la fleur de la vie contemporaine; [...]. C'est la plus chaleureuse manifestation de la vitalité des hommes d'aujourd'hui, de leur puissance, de leur puérilité, de leur don d'invention et d'imagination, et la plus belle réussite de leur volonté de moderniser le monde dans tous ses aspects et dans tous les domaines. [...] Oui, vraiment, la publicité est la plus belle expression de notre époque, la plus grande nouveauté du jour, un Art [...]. Paris, 26 février, $1927 .^{1}$ Blaise Cendrars

${ }^{1}$ Blaise Cendrars, Aujourd'hui 1917-1929 suivi d'essais et réflexions 1910-1916, Paris: Denoël, 1987, p. 117. O texto Publicité = poésie, dedicado a Cassandre, corresponde: “A publicidade é a flor da vida contemporânea; [...]. É a mais calorosa manifestação da vitalidade dos homens de hoje, de seu poder, de sua puerilidade, de seu dom de invenção e de imaginação, e o mais belo resultado de sua vontade de modernizar o mundo em todos os seus aspectos e em todos os campos. [...] Sim, verdadeiramente, a publicidade é a mais bela expressão de nossa época, a maior novidade do dia, uma Arte”. 
Para Blaise Cendrars a publicidade é uma arte e ocupa o sétimo lugar dentre as principais maravilhas do mundo moderno. As qualificações que o poeta atribui à publicidade, ora referida como uma arte ora como poesia, ou então como a mais bela expressão da época apontam para a complexidade do assunto desta tese - que apesar de ter por núcleo central o exame da contribuição do artista plástico de 1920 a 1940 à publicidade comercial brasileira, ${ }^{2}$ se desenvolve interdisciplinarmente devido às exigências que permeiam a relação entre arte e publicidade, sobretudo nos anos aqui considerados.

A delimitação cronológica imposta ao estudo, dos anos 20 aos anos 40, deve-se a três principais motivos:

- a década de 20, ampliou a discussão sobre os preceitos da arte moderna internacional, estimulando entre nós o debate em torno de uma produção artística nacional atualizada, a qual poderia ter sido incorporada à publicidade brasileira, visto esta dispor da atuação dos artistas plásticos, caricaturistas e ilustradores. Esses anos também constituíram um período dos mais importantes para a relação arte e publicidade internacional;

- o "surgimento" da profissão de designer na década de 50, considerada "um marco fundamental na formação dos grandes profissionais da comunicação visual no Brasil”. ${ }^{3}$ O designer gráfico e o artista gráfico, termos muitas vezes empregados indistintamente, ocupam cada vez mais postos no mercado de trabalho, enquanto o artista plástico desvia-se daquele profissional pioneiro da comunicação visual das décadas anteriores, que interessa mais de perto à nossa investigação. $^{4}$

\footnotetext{
2 Por publicidade comercial entendemos àquela que envolve produtos, serviços e empreendimentos comerciais de várias naturezas, tanto de iniciativa privada como pública.

3 Alexandre Wollner, "Comunicação visual”, in Walter Zanini, História geral da arte no Brasil, São Paulo: Instituto Walther Moreira Salles: Fundação Djalma Guimarães, 1983, v. II, pp. 953-971. Rafael Cardoso considera que no período 1951-1963 não surgiu "o design propriamente dito - ou seja, as atividades projetuais relacionadas à produção e ao consumo em escala industrial -, mas antes a consciência do design como conceito, profissão e ideologia”. O autor ainda menciona que "houve sim uma ruptura por volta de 1960 e que esta inaugurou um novo paradigma de ensino e exercício da profissão, o qual corresponde hoje àquilo que entendemos por design neste país”. Sobre o assunto consultar Rafael Cardoso (org.), O design brasileiro antes do design: aspectos da história gráfica, 1870-1960, São Paulo: Cosac Naify, 2005, pp.7 e 10.

${ }^{4}$ Esclarecemos que, ao utilizarmos a designação design gráfico e/ou seu correspondente profissional, assim procedemos pela existência de um consenso geral que considera o design
} 
- as novas ações e diretrizes adotadas nos anos 50 pelos então mentores da publicidade brasileira, a destacar o primeiro curso de arte publicitária instalado no Instituto de Arte Contemporânea do Museu de Arte Assis Chateaubriand, semente da futura Escola de Propaganda e Marketing, que foram determinantes para a profissionalização do publicitário.

Investigar os diálogos entre as artes plásticas e a publicidade comercial no Brasil, de imediato, nos coloca uma questão central: podemos falar em diálogo como um fluxo, com empréstimos, contaminações e circulação livre de imagens, tanto da arte maior para a arte menor como vice-versa? Nossas artes plásticas e publicidade realmente engendraram diálogos? De que natureza eles foram?

Se as contaminações da publicidade na arte maior que tanto enriqueceram a produção internacional, sobretudo se levarmos em conta o seu uso nas práticas cubistas, dadaístas, futuristas, surrealistas, construtivistas e outras, são bastante numerosas, no Brasil, este procedimento não ocorreu com tanto entusiasmo, pois o nosso ambiente artístico, bastante tímido em avanços vanguardistas, ainda estava se enamorando das formulações da arte moderna e dando seus primeiros passos rumo à constituição de uma arte moderna brasileira, a qual, no decorrer das décadas, foi mediada por distintos perfis. De modo que, no arco temporal selecionado, os exemplos seriam raros, ${ }^{5}$ basta lembrarmos os principais grupos e alianças artísticas que surgiram no período, quase todos ancorados num modernismo moderado, orientado muitas vezes pelo "retorno à ordem”, a exemplo do Grupo Santa Helena (São Paulo, c. 1935-1944), Núcleo Bernardelli - Movimento Livre de Artistas Plásticos (Rio de Janeiro, 1931-1942), Grupo Seibi (São Paulo, 1935-1972), Grupo Guignard (Rio de Janeiro, 1943-1944), Grupo Portinari (Rio de Janeiro, 1935-1937), Grupo 15 (São Paulo, 1948-1949) e Grupo Guanabara (São Paulo, déc. 50), e ainda, a Sociedade Pró-Arte Moderna - SPAM ${ }^{6}$ (São

gráfico como aquele relativo à publicidade e a indústria editorial em suas atividades e especificidades tipográficas.

${ }^{5}$ Uma evidente contaminação da publicidade na arte maior torna-se mais freqüente a partir das décadas de 70, a exemplo de alguns trabalhos da artista Ana Bella Geiger: BuROCRACIA (1975), SOBRE A ARTE (1976) e AUTO-RETRATO-BUROCRACIA (1980), os quais aludem ao anúncio comercial do medicamento Lugolina.

${ }^{6}$ Como curiosidade, a capa do catálogo da I Exposição de Arte Moderna da SPAM, 1933, menciona que se trata de uma mostra de pintura, escultura e arquitetura. Essa referência às tradicionais belas artes em anos modernistas, demonstra o quão nos mantínhamos na esfera da manutenção das hierarquias artísticas. 
Paulo, 1932-1934), o Clube dos Artistas Modernos - CAM (São Paulo, 1932-1933), os Salões de Maio e da Família Artística Paulista - FAP (São Paulo, 1937-1940).

Assim sendo, no decorrer de nossas pesquisas e exames optamos por não incluir as absorções e contaminações da publicidade nas obras artísticas, por ter em conta que, além de ser um acentuado desvio do nosso foco principal e que bem poderia constituir um outro estudo, diálogo é para nós antes uma contribuição do profissional das artes plásticas à publicidade brasileira do que um fluxo de contaminações entre as chamadas artes maiores e menores.

Necessariamente, uma outra discussão atrelada à anterior surge e precisa ser elucidada para afastar possíveis leituras equivocadas que possam sobrevir em função do emprego dos termos artes maiores e artes menores. Distantes de um juízo crítico por nós emitido, essas designações são de uso corrente tanto no plano internacional como no nacional. Lembramos que em 1963, Quirino Campofiorito se utilizava da expressão artes maiores ao abordar a vaidade que a Escola Nacional de Belas Artes do Rio de Janeiro nutria pelos seus ensinos, em função de serem uma “continuidade atualizada” da Academia Imperial de Belas Artes. ${ }^{7}$

Longe de tentar resolver teoricamente as diferenças entre arte e publicidade, mas não deixando de ter em conta pelo menos as suas principais, como a sua produção, função e recepção, reconhecemos a polêmica que envolve o assunto e que promoveu quase que concomitantemente duas importantes exposições nos anos iniciais da década de 1990, High and Low: Modern Art and Popular Culture no Museum of Modern Art de New York e Art \& Publicité 1890-1990 no Centre Georges Pompidou. A mostra americana examinou essa relação sob o ponto de vista de como a publicidade contribuiu, segundo os interesses dos próprios artistas, para a modernidade da arte maior, numa curadoria que reafirmou as hierarquias artísticas, enquanto a mostra francesa subverteu essa lógica conservadora para se deter na imagem, nos pontos comuns entre a imagem artística e a imagem publicitária.

Se um olhar ou outro são insuficientes para dar conta do assunto em suas especificidades, colocamos-nos ao lado de teóricos mais atuais, como Juan Acha, Dino Formaggio, Marc Le Bot, Mikel Dufrenne e Georges Roque, que procuram rever e alargar a visão que temos não só das hierarquias artísticas, mas também das técnicas

${ }^{7}$ Quirino Campofiorito, “Artes industriais e as tradições do ensino artístico no Brasil”, Arquivos da Escola Nacional de Belas-Artes, Rio de Janeiro, (9): 75-76, 12 ago. 1963. 
artísticas, sobretudo a das artes menores, procurando encontrar um locus para as mesmas, procedimento que dispôs de análises apoiadas não só no campo artístico, mas também no estético.

Em vista do exposto, empregamos o termo arte maior por seu uso secular dentro das hierarquias artísticas, que a situa dentre as consagradas belas artes - as artes nobres da pintura e da escultura. Já as artes menores, dirigem-se ao campo das artes aplicadas (por vezes artes decorativas) da qual fazem parte, entre outras modalidades, tanto a publicidade como o campo editorial. Enfatizamos que estes termos serão também empregados ou citados por nós consoante a utilização da época, daí as suas possíveis variações.

A propósito da oposição que os termos arte menor e arte maior carregam consigo, nós procuramos não enfatizar essa visão hierárquica e depreciativa, mas não podemos deixar de constatar a sua existência, mesmo porque, como pretendemos demonstrar, essa relação conflituosa está diretamente associada a uma hierarquia social, e consequentemente ao campo artístico. Nosso estudo também procurou reconhecer momentos, nas peças publicitárias dos artistas plásticos, que estavam próximos ou “contaminados” por suas produções pessoais ou mesmo por seus interesses estilísticos. Assim, a partir de uma investigação do campo estético, concluímos que a arte menor e a arte maior não são dois mundos separados e fechados, porém, não é fácil estabelecer uma linha demarcatória entre eles. Estas breves observações justificam os motivos que nos levaram a questionar essa específica hierarquia artística, a qual tão bem o modernismo colocou em xeque. E, por fim, ressaltamos, mais uma vez, que o emprego que fazemos dessas categorias não visa afiançar nenhuma hierarquia de valor, mas delas nos servimos para a análise crítica dos objetos em discussão.

Do mesmo modo alertamos sobre a difícil conceituação das palavras reclame, propaganda e publicidade. Uma tarefa nada simples, pois, de antemão é lícito afirmar que muitas vezes esses termos, a destacar propaganda e publicidade, foram e seguiram sendo utilizados sob o mesmo significado.

$\mathrm{Na}$ realidade, esse emprego indistinto dos termos reclame, propaganda e publicidade não é uma ocorrência somente nossa. Na França, ${ }^{8}$ apesar do vocábulo publicidade substituir progressivamente o de reclame, são termos que convivem desde

\footnotetext{
${ }^{8}$ No último quarto novecentista francês, o Dictionnaire de l'Academie française registrava que o termo publicidade era usado tanto para designar anúncios nos jornais, como também cartazes e prospectos. Consultar Marie-Emmanuelle Chessel, La publicité: naissance d'une profession 1900- 1940, Paris: Éditions CNRS, 1998, p. 11.
} 
meados do século XIX sendo empregados como sinônimos até a segunda metade do século XX. Entretanto, a partir de 1932, agrega-se à palavra reclame um sentido pejorativo, em função de ela estar associada ao período empírico da propaganda francesa. Com a profissionalização efetiva dos publicitários, o termo publicidade passa a ter mais prestígio por ancorar-se em procedimentos metódicos e organizados, afinando-se com os propósitos da classe.

No Brasil, encontramos algumas definições que se aproximam de:

- reclame (clamor, chamamento): todo tipo de propaganda comercial (anúncio, cartaz, prospecto, jingle, e outros). Ou "pequeno artigo incerto no corpo do jornal contendo elogio de uma obra artística ou literária ou das mercadorias que se anunciam”. Já anúncio seria “a mensagem que quem vende dirige a quem compra, oferecendo um benefício”. O anúncio pode ser impresso, falado, musicado e projetado, e, tecnicamente, é denominado peça publicitária”.9

- propaganda: propagação de princípios, teorias, conhecimentos e idéias com o objetivo de persuadir;

- publicidade: um produto da sociedade de consumo, portanto vinculado ao exercício decorrente de ações psicológicas sobre a opinião pública com fins comerciais. Ou, melhor, a adoção de um conjunto de estratégias destinadas a levar ao conhecimento do público, através dos meios de comunicação de massa, um bem, um produto ou um serviço, de modo a incitar-lhe à aquisição.

Dicionários especializados em comunicação e propaganda não resolvem o problema, e seus autores reconhecem essa dificuldade quando mencionam que no Brasil e em

alguns outros países de língua latina, as palavras propaganda e publicidade são geralmente usadas com o mesmo sentido, e esta tendência parece ser definitiva, independentemente das tentativas de definição que possamos elaborar em dicionários ou em livros acadêmicos. Em alguns aspectos, porém, é possível perceber algumas distinções no uso das duas palavras: em geral, não se fala em publicidade com relação à comunicação persuasiva de idéias (neste aspecto, propaganda é mais abrangente, pois inclui objetivos ideológicos, comerciais etc.); a publicidade mostra-se mais abrangente no sentido de

\footnotetext{
${ }^{9}$ Pedro Nunes, 35 anos de propaganda, Rio de Janeiro: Gernasa, s.d., pp. 21-22.
} 
divulgação (tornar público, informar, sem que isso implique necessariamente persuasão). ${ }^{10}$

Diante dessas terminologias cujos sentidos são permeáveis tomamos a decisão de também seguir a linguagem da época com a qual estamos trabalhando procurando padronizar, quando possível, os seus usos de uma forma mais próxima de nossas intenções. A exemplo, empregaremos a expressão agências de propaganda e não agências de publicidade, sendo que reclame, propaganda comercial ou anúncios comercias, serão utilizados quase que indistintamente.

\section{Metodologicamente DiÁLOGo ENTRE AS ARTES PLÁSTICAS E A PUBLICIDADE NO}

BRASIL reúne três abordagens: histórica ao tratar do desenvolvimento da publicidade comercial brasileira, da reconstituição biográfica dos artistas plásticos que se envolveram com a publicidade, do reconhecimento do campo artístico e mercado de trabalho, comparativa por verificar os diálogos da produção nacional com os modelos em circulação, sejam eles de matriz européia e/ou americana, e, por final, uma leitura

formal visando examinar os possíveis elementos plásticos modernos presentes nas peças publicitárias.

Observamos que nossa linha condutora às vezes se apresenta menos reflexiva e mais informativa para que assim se possa melhor visualizar a situação dos temas abordados, para depois, então, ser possível proceder às análises e às construções hipotéticas.

Como testemunha o primeiro capítulo, Do RECLAME À PUBLICIDADE, não foi nossa pretensão reescrever a história da propaganda brasileira, ${ }^{11}$ apesar dela ser inseparável e nutrir o nosso estudo. Uma história que se constituiu e centralizou-se, pelos menos até a década de 1950, em dois estados brasileiros, São Paulo e Rio de

${ }^{10}$ Carlos Alberto Rabaça; Gustavo Guimarães Barbosa, Dicionário de Comunicação, São Paulo: Editora Ática, 1987, p.481.

${ }^{11}$ O publicitário José Roberto Whitaker Penteado chama a atenção para a inexistência de um trabalho revisional sobre a evolução da publicidade comercial brasileira, constatação esta atribuída ao desinteresse dos pesquisadores das nossas universidades. Depoimento de José Roberto Whitaker Penteado à autora, São Paulo, abr. 2002. Essas observações são novamente citadas no ensaio "A crucial década de 30 na história da propaganda brasileira” publicado na catálogo Os "reclames” de Fulvio Pennacchi: primórdios da propaganda brasileira, São Paulo: Instituto Moreira Salles, maio 2005, p. 102. Nele, Whitaker comenta que a partir dos anos 40 do século passado "o registro das atividades profissionais nas áreas de propaganda e marketing tornou-se mais fácil de levantar, pois houve a presença importante da revista semanal Publicidade \& Negócios (PN) [...]. Mas, em termos de pesquisa, há ainda muito a se fazer, em especial cobrindo os períodos que incluem todo o século XIX e o século XX, do seu início até o fim da Segunda Guerra Mundial”. 
Janeiro. Assim sendo, optamos por dela extrair os seus principais fatos e características de modo a reunir informações que venham a contribuir para o estudo e exame dos diálogos entre as artes plásticas e a publicidade no Brasil; e, do mesmo modo procedemos em relação à propaganda internacional, que vez ou outra é citada para nos auxiliar no entendimento dos mecanismos publicitários do período. E, ambas, ao longo dos capítulos, servem de apoio para reflexões e exames, seja como suporte para discussões plásticas formais, seja para compor o mercado de trabalho, ou mesmo para acompanhar a passagem do profissional do desenho ao artista publicitário. Ainda, neste núcleo secundário, em relação à propaganda internacional, foi necessário verificar os contatos entre a americana e a européia, visto que a propaganda brasileira constitui-se, tanto pela presença das agências americanas no Brasil, como também pela presença dos artistas gráficos europeus no mercado de trabalho, ora chefiando equipes, ora compondo o quadro funcional do departamento de arte, e, por último, pela circulação de publicações internacionais. Complementa o primeiro capítulo uma evolução da imagem publicitária brasileira. Finalmente, não deixamos de considerar o “estilo brasileiro", expressão empregada e reconhecida pelos publicitários Caio A. Domingues e Ricardo Ramos, quando ainda não havíamos absorvido os modelos da propaganda norteamericana.

Ao compor esse quadro-panorama da nossa publicidade, deparamos com uma bibliografia quase toda ela ancorada em depoimentos daqueles pioneiros ${ }^{12}$ que praticamente estiveram à frente não só das principais agências de propaganda, como também das instituições representativas da classe profissional. Deve-se considerar que, se por um lado, esses atores dão o alicerce à construção da memória da nossa propaganda, por outro lado, reduzem as possíveis diversidades dessa história, por estarem demasiadamente comprometidos com ela.

Os estudos recentes, que abordam esses anos da nossa propaganda, acabam por gravitar em torno da mesma bibliografia e, portanto, dos mesmos depoimentos, visto que muitos deles não têm como foco acompanhar, como nós, minuciosamente a sua evolução, e sim dela emprestar argumentos para outras discussões e análises. ${ }^{13}$

\footnotetext{
${ }^{12}$ Seriam eles Aldo Xavier da Silva, Armando de Moraes Sarmento, Charles Ullman, Charles D. Dulley, Cícero Leuenroth, Jorge Mathias, Júlio Cosi, Renato Castelo Branco, Rodolfo Lima Martensen, Sylvio Behring, entre tantos outros.

${ }^{13}$ A exemplo das dissertações de mestrado de Paulo Sutti, O reclame: a transição da reprodutibilidade persuasiva, São Paulo: Pontíficia Universidade Católica de São Paulo, 1996; e João Anzanello Carrascoza, O algo mais na publicidade brasileira dos anos 90: um
} 
A referida interdisciplinaridade mencionada na página inicial desta introdução, pode ser observada em vários momentos da tese. Primeiramente, chamamos a atenção para a diversidade de títulos e assuntos que compõem a bibliografia na qual optamos por reunir somente o material citado ou estudado diretamente. Deixamos de lado algumas referências secundárias que ao longo da pesquisa serviram de guia e fontes para a localização de dados mais significativos, a exemplo de livros e revistas da área farmacêutica que dão indícios sobre os primórdios da prática publicitária brasileira, muitos deles mencionando a participação dos poetas na redação de reclames dos laboratórios nacionais.

Nossas dificuldades foram várias, a exemplo da ausência de assinaturas nos anúncios comerciais, mas a que prevaleceu e de certa forma nos fez remodelar o nosso projeto inicial foi a não localização dos cartazes de época. Fato, este, determinante que direcionou nossa atenção aos projetos $\operatorname{cartazísticos~}^{14}$ e aos reclames autorais, estes últimos veiculados, sobretudo em diversos periódicos, sejam eles de circulação ampla ou restrita. Devemos ter em conta que, muito provavelmente no Brasil, a preferência pela arte maior tenha sobrepujado o interesse pelo cartaz, sem contar que este sendo um veículo efêmero compromete a formação de uma coleção. Por conseguinte, não contamos com coleções de museus $^{15}$ e arriscamos a afirmar até mesmo de colecionadores, ficando distantes da riqueza e diversidade de uma coleção como a do Musée de la Publicité. ${ }^{16}$ Por outro lado, essa constatação nos remete a refletir se realmente houve, nos anos considerados, uma produção cartazística nacional, pois verificamos que nossos artistas foram formados antes para a ilustração de revistas e livros do que propriamente para a confecção de cartazes que tem características próprias que o distinguem de outros suportes.

estudo sobre a rede semântica no texto publicitário de mídia impressa, São Paulo: Escola de Comunicações e Artes da Universidade de São Paulo, 1998.

${ }^{14}$ Neste particular, os projetos cartazísticos do artista Fulvio Pennacchi subsidiam o núcleo mais denso de nossas análises formais.

15 Poderíamos citar o Museu do Cartaz de Curitiba (1981). Sua coleção é composta essencialmente de cartazes de peças e apresentações de grupos do teatro brasileiro, datados em sua maioria a partir da década de 1960. Cf. Adélia Maria Lopes, "Brasil já tem museu do cartaz. Em Curitiba”, O Estado de S. Paulo, 12 jul. 1981.

${ }^{16}$ Cerca de 40.000 cartazes que hoje pertencem à coleção do Musée de la Publicité (1982) Union Centrale des Arts Decoratifs, até 1978 constituíam um departamento da Biblioteca das Artes Decorativas. Na França, a valorização e o interesse crescente pelas artes gráficas aplicadas à publicidade manifestam-se a partir de 1955 com Raymond Cogniat. Sobre a história do Musée de la Publicité e de suas coleções consultar 150 ans de publicité: collections du Musée de la Publicité, Paris: Union Centrale des Arts Décoratifs, 2004, pp. 8-11. 
Investigar como se deu o contato da publicidade com as artes plásticas brasileiras dos anos 20-40 do século XX implica necessariamente em um exame das suas especificidades e das suas diferenças, o que, por sua vez, conduz a outros exames, aos quais nos dedicamos no segundo capítulo - MERCAdo DE TRABALHO. Indagações, sobre a composição das classes profissionais envolvidas, ou seja, quem eles eram e quais eram suas principais atividades, como nossos artistas se colocavam no mercado artístico no decorrer dos anos, que estratégias eles adotaram, ou não, para contornar a passagem de um sistema acadêmico para um moderno, constituem temas que certamente puxam outros para a discussão.

A fim de facilitar uma aproximação com o mercado de trabalho, elaboramos três tipos de tabelas a partir das atividades profissionais mais conhecidas ou relevantes de cada artista citado neste estudo: Artistas Plásticos e Arquitetos // Artistas Gráficos: Ilustradores e Caricaturistas // Publicitários e Cartazistas (vide APÊNDICE). Foi nossa preocupação reunir o máximo de informações sobre a participação dos artistas na propaganda brasileira, mesmo que não tenha sido possível localizar suas peças publicitárias, por julgarmos que não deixa de ser uma contribuição àqueles que porventura venham a estudar o assunto.

Na investigação biográfica dos artistas plásticos, sobretudo daqueles que pouco foram estudados ou ainda daqueles que não receberam uma biografia atualizada coerente ao enfoque defendido por Pierre Bourdieu em seu ensaio "L’illusion biographique”, ${ }^{17}$ constatamos duas vias, uma na qual a atuação do artista na publicidade brasileira era mencionada, mas de modo irrelevante diante da evolução da carreira do artista, muitas vezes um começo na profissão ou um modo de sobrevivência material; uma segunda, em que não era citada a sua participação, e dela só tomamos conhecimento pelo encontro da peça publicitária. Essas ocorrências não ficam só por conta dos biógrafos, encontramos auto-biografias, ou melhor, depoimentos, a exemplo de Danilo Di Prete, que diminuem o valor de suas experiências com as artes menores, em prol da afirmação de sua arte maior, geralmente, a pintura, reconhecidamente um caminho de sucesso.

Uma outra discussão que emerge deste estudo, também já mencionada anteriormente, é a hierarquia das artes que irá retomar temas consagrados, como a querela entre as artes liberais e as artes mecânicas, a polêmica entre artes maiores e

17 Ver Pierre Bourdieu, “L' illusion biographique”, Actes de la Recherche em Sciences Sociales, Paris, (62-63): 69-72, juin 1986. 
menores, entre arte pura e arte aplicada, o artista como gênio com criação única versus uma produção que lhe escapa das mãos, enfim vários enfoques serão pinçados e estudados conjuntamente para que possamos edificar um quadro teórico que permita uma reflexão fundamentada e mais adequada à questão. Nosso intento foi verificar se esta foi ou não uma questão importada em nosso meio artístico. Neste particular, compusemos uma análise comparativa com os escritores e poetas, como atesta o item COMPOSIÇÕES ENTRE O LÁPIS E A PENA NA PROPAGANDA BRASILEIRA. Complementando esse item julgamos pertinente apresentar como um estudo de caso a Revista do Globo, por acreditarmos que ela reúne procedimentos de época significativos e extensivos a outras revistas.

Será necessário, a exemplo da participação dos poetas na publicidade brasileira, ${ }^{18}$ romper com os limites temporais estabelecidos, ora retrocedendo aos primeiros anos do século XX e até mesmo ao século anterior, para tornar possível o entendimento do mercado de trabalho ora avançando para os anos 50, para verificar o processo de configuração daquele profissional específico da área, o publicitário.

Ainda, dentro desse tema, que é bastante diversificado pelas variáveis que o compõem foi necessário recuperar a reforma que Araújo Porto-Alegre propôs à Academia Imperial de Belas Artes como também as de Rui Barbosa voltadas para o ensino primário e secundário, pois elas permitiram acompanhar a visão de ensino da arte da época e averiguar se houve uma produção voltada para as artes aplicadas (incluindo as artes gráficas) reconhecida não só pelas instâncias culturais e artísticas, como também pela indústria nacional. Este item igualmente proporcionou uma confrontação com o panorama internacional e, principalmente com as medidas adotadas por países como a Inglaterra, França e Alemanha, que foram determinantes para o desenvolvimento do design gráfico, no qual a publicidade se insere.

Uma vez apresentados os artistas produtores de peças publicitárias e as motivações que os mobilizaram para essa produção, optamos por organizar tipologias que dessem conta do material iconográfico e obedecessem a determinados componentes estilísticos. A seleção de imagens foi realizada de modo a apresentar de cada artista toda a produção que nos foi possível localizar, mas quando de um grande número de

\footnotetext{
${ }^{18}$ Não foi nosso objetivo analisar os textos publicitários dos poetas. Dentre esse propósito encontra-se, entre outros, o estudo de Flora Süssekind, Cinematógrafo de letras: literatura, técnica e modernização no Brasil, São Paulo: Companhia das Letras, 1987.
} 
anúncios comerciais, a exemplo de Acqua e Seth, optamos por aqueles que não repetissem formulações estilísticas.

É no último capítulo que apresentamos o moderno artístico internacional e nacional, e neste considerando as transformações que o decurso das décadas engendraram, momento este em que também historiografamos brevemente a contribuição das artes à publicidade internacional.

Para definirmos qual era a nossa estética moderna, colocamos o código maior, o internacional, num plano crítico, para que este não se impusesse sobre a nossa produção, a qual deve ser analisada e compreendida em suas variantes. Por outro lado, torna-se indispensável definir o que é o moderno para a propaganda e para as artes plásticas. Enfatizamos que não tratamos de analisar o papel da publicidade na consolidação de um discurso da modernidade e nem a sua recepção. Assim, atribuímos o valor de moderno à propaganda, posição consensual na publicidade mundial, quando da sua ligação aos métodos racionais americanos, enquanto que no campo estético, tanto das artes plásticas quanto da arte publicitária, seguem nossas proposições, ou seja, os seus vínculos com as linguagens estéticas das vanguardas artísticas sem desrespeitar as suas adaptações e variantes locais.

O conjunto das peças publicitárias concebidas pelas diversas categorias de artistas visuais atuantes no Brasil e que foram mencionados ao longo deste estudo, no geral, aponta para três possíveis caminhos: o da caricatura à ilustração, o das incursões pelas letras e imagens, e o do reclame ao cartaz publicitário moderno. Dessa reunião, para as análises críticas, elegemos algumas imagens em função de suas representatividades formais que nos interessam mais de perto, por sua vez, as exclusões ocorreram devido às formulações artisticamente pouco expressivas e instigantes e/ou por serem iconografias publicitárias que se repetem no período. Apesar dessa última condição, elas figuram no catálogo de imagens por darem o testemunho da existência de uma produção de anúncios e cartazes comerciais dos nossos artistas plásticos, gráficos e publicitários.

Nossa leitura é, até certo ponto, diacrônica, verticalizando-se quando do reconhecimento de códigos modernos, o que foi determinante para enveredar entre dois eixos que se vêem associados principalmente aos artistas do Rio de Janeiro e São Paulo. De modo geral, defendemos a tese de que os últimos por estarem mais próximos da linguagem pictórica ou mesmo da cartazística, a exemplo de Pennacchi, vinculam-se a uma modernidade estética, enquanto os cariocas dão o testemunho de uma posição mais 
conservadora em termos de imagens publicitárias, muito mais próxima da disciplina do desenho, que é tido como uma atividade associada ao espaço profissional, ao passo que a pintura estaria voltada ao cultural, portanto de expressão mais livre. E, finalmente na produção publicitária brasileira selecionada verificamos se ela é ou não é uma reelaboração particular de modelos em circulação - europeu e/ou americanos - ou ela é descolada de referências.

Partindo do fato de que nenhum estudo sistemático tenha examinado a contribuição dos artistas plásticos à publicidade brasileira dos anos 1920-1940, acreditamos que esse trabalho, ao produzir um novo conhecimento, possa vir a preencher essa lacuna historiográfica tanto da área das artes visuais, como também da propaganda. Por sua vez o resgate dos anúncios publicitários em diversos suportes, que raramente são considerados, devido ao privilégio concedido à pintura, à escultura, à fotografia e à ilustração, enriquece e alarga o debate dos nossos campos estético e artístico. 
CAPítulo 1

Do RECLAME À PUBLI CI DADE 
- Mal podeis adivinhar o que me deu idéia da nova doutrina; foi nada menos que a pedra da lua, essa insigne pedra tão luminosa que, posta no cabeço de uma montanha ou no píncaro de uma torre, dá claridade a uma campina inteira, ainda a mais dilatada. Uma tal pedra, com tais quilates de luz, não existiu nunca, e ninguém jamais a viu; mas muita gente crê que existe e mais de um dirá que a viu com os seus próprio (sic.) olhos. Considerei o caso, e entendi que, se uma coisa pode existir na opinião, sem existir na realidade, e existir na realidade, sem existir na opinião, a conclusão é que das duas existências paralelas a única necessária é a da opinião, não a da realidade, que é apenas conveniente.

$[\ldots]$

- Não me parece, atalhei, que tenhais cumprido a doutrina em seu rigor e substância, pois não nos cabe inculcar aos outros uma opinião que não temos, e sim a opinião de uma qualidade que não possuímos; este é, ao certo, o essencial dela. ${ }^{1}$

Machado de Assis

1 Machado de Assis, "O segredo do bonzo. Capítulo inédito de Fernão Mendes Pinto", in Papéis avulsos, s.l.: Lombaerts \& C., 1882. A citação empregada se encontra disponível no site www.bibvirt.futuro.usp.br/textos/autores/machadodeassis/papeisavulsos/segredo.html (pp. 3-4/5)13/10/2005 14:51:06. 


\subsection{PROPAGANDA BRASILEIRA NOS ANOS 1920-40}

O mordaz, crítico e satírico, conto $\mathbf{O}$ segredo do bonzo ${ }^{2}$ desnuda a publicidade em seus exercícios manipuladores de persuasão que vão do segredo ao absurdo e do enganoso ao convencimento. Se no tempo da publicidade escrita, o que faz valer é a palavra, a “dona loureira e senhoril”, de ética questionável, usa da linguagem de posses objetivas e subjetivas que ela mesma trama e se constrói para mistificar, criar armadilhas. E a desconfiança que impregna o leitor machadiano que acompanha as suas estratégias, será também aquela intuída e partilhada pelos comerciantes de futuras décadas, como dão a ver os dizeres: "propaganda e esmola só aos sábados das 9:00 às 11:00 hs” ou “esta casa só dá esmolas aos sábados e não atende a gente de publicidade”. Estes avisos afixados em lojas comerciais dos anos 20 do século XX, nos levam a crer que a propaganda brasileira na época não era vista com bons olhos e, conseqüentemente, também “o homem de propaganda”. $\mathrm{Na}$ realidade, existem referências de que esses avisos já eram expostos nas casas comerciais desde o século anterior, prática que parece ter perdurado até a década de $1930{ }^{3}$

Se os principais motivos de tal desconfiança assentam-se na manipulação e mistificação da informação e conseqüentemente da realidade, outros fatores podem ser acrescidos a partir de um anúncio comercial localizado na revista Ariel: Revista de Cultura Musical, que reforça de um modo peculiar o menosprezo pelo uso de anúncios; nele além do desenho de um piano e o nome da empresa que o comercializa consta somente um simples e direto comentário: "Não precisa reclame" ${ }^{4} \mathrm{Na}$ ambiência da época, acreditamos que este tipo de mensagem traz implícito um questionamento sobre os verdadeiros "benefícios da publicidade”. Prefere, o anunciante, apostar diretamente na qualidade e na marca de seu produto, e na capacidade de persuasão dos vendedores da casa, amparada no conhecimento que estes têm dos produtos que vendem

\footnotetext{
${ }^{2}$ Na Nota C, ao final do seu conto, Machado de Assis, explica que "o bonzo do meu escrito chama-se Pomada, e pomadistas os seus sectários. Pomada e pomadista são locuções familiares da nossa terra: é o nome local do charlatão e do charlatanismo. Idem, s.p.

${ }^{3}$ Nos anos 30 ainda era freqüente encontrar na porta de entrada das indústrias e nos escritórios das casas comerciais tabuletas com dizeres semelhantes ao reproduzido no texto acima. Ver Armando de Moraes Sarmento, "As agências estrangeiras trouxeram modernidade, as nacionais aprenderam depressa”, in Renato Castelo Branco et alii, História da propaganda no Brasil, São Paulo: T. A. Queiroz, 1990, p. 20.

${ }^{4}$ Consultar Ariel: Revista de Cultura Musical, São Paulo, (5): s.p., fev. 1924.
} 
e na informação que prestam aos seus clientes. Esta possibilidade se confirma num anúncio da Empresa Moderna de Reclame* que propagava a vantagem do uso dos reclames, pois "os seus melhores vendedores podem deixar-vos e prestar a outros seus serviços”.

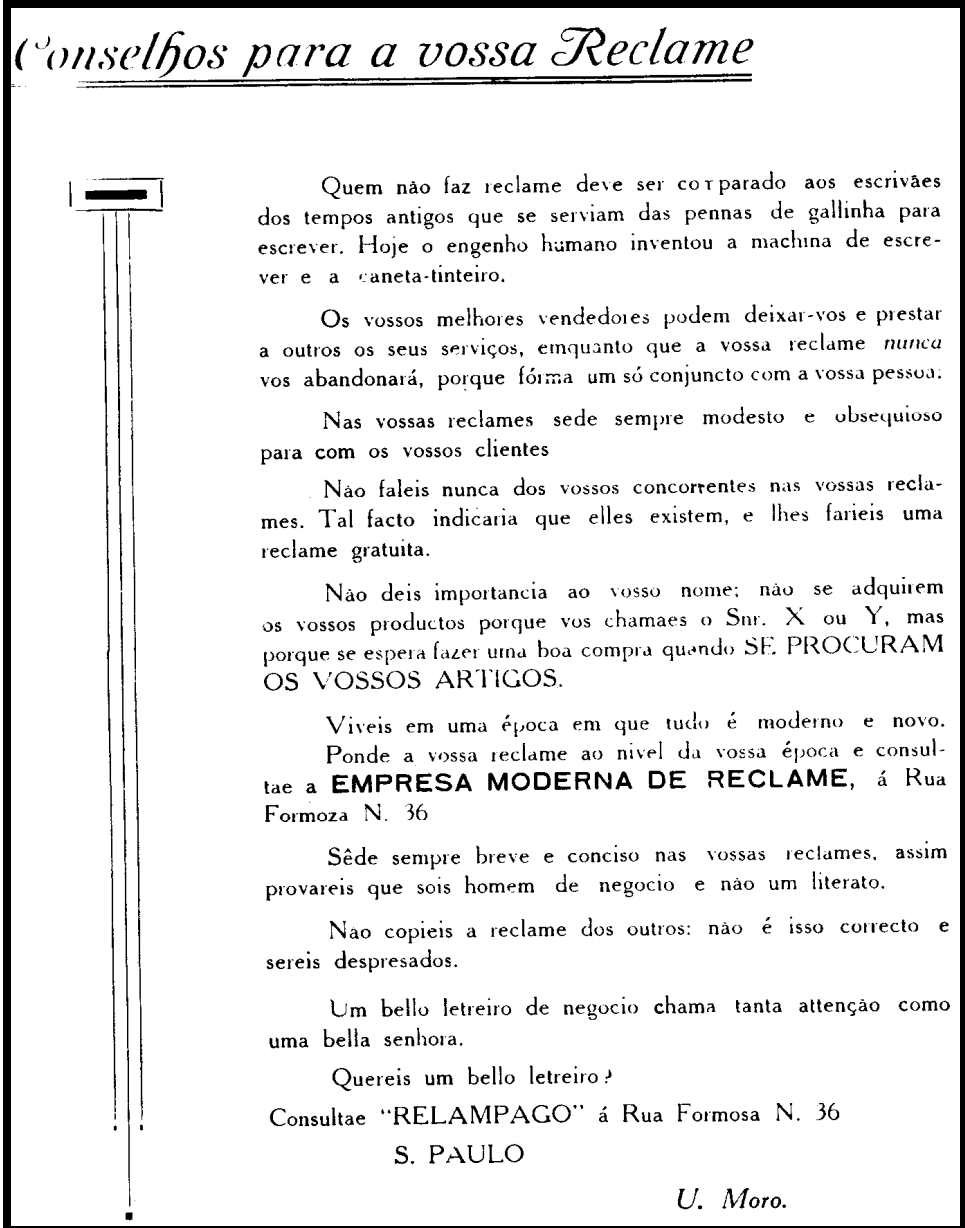

*A Cigarra, São Paulo, 20 abr. 1914.

Por sua vez, o conselho "Sêde sempre breve e conciso nas vossas reclames, assim provareis que sois homem de negócio e não um literato”, é um claro indício que a propaganda não era apenas construção literária, o que também não deixa de ser uma crítica dos "homens de propaganda" aos seus concorrentes redatores, os homens da pena.

“Copiar reclames dos outros”, também deveria ser comum e funcional para a época. Um testemunho próximo dessa ocorrência, são as declarações de profissionais ligados à imprensa, que confirmam o uso da tesoura e da cola na produção de anúncios 
e ilustrações, como veremos no capítulo seguinte. Um segundo exemplo, revelador de práticas no comércio foi a demonstração que Jean-Louis Fretin, concedeu-nos sobre o modo como o seu pai, Louis Fretin, elaborava os anúncios em vários idiomas da Casa Fretin, nas primeiras décadas do século XX; uma produção caseira, na qual simplesmente eram recortadas as figuras de um reclame da empresa já publicado e acrescidas de frases de um outro idioma, sendo depois o material enviado para a realização do clichê. ${ }^{5}$

Desses breves exemplos introdutórios, capitaliza-se a fala de três setores que dirigem à publicidade ações, interesses e críticas distintas, são eles, os anunciantes/comerciantes/empresários, os literatos/jornalistas e os "homens de propaganda”. De forma que o descrédito conferido à publicidade, que também ocorreu no plano internacional, sobretudo na França no entre-guerras, do primeiro grupo associa-se, como vimos, ao fato da casa comercial e seus produtos serem conhecidos mesmo sem tradição publicitária, neste caso a propaganda além de custosa seria inútil para a empresa ou ainda um "expediente pouco recommendavel” a uma firma ou mercadoria de certa classe, enquanto que para o segundo grupo, representado aqui por Machado de Assis, a crítica se dirige ao seu poder de manipulação e credibilidade. ${ }^{6}$ Por sua vez, os "homens de propaganda", procuram de todas as formas legitimar sua profissão. Em resposta, apóiam-se no papel educativo dos reclames, na concorrência livre, daí a necessidade da propaganda ser uma atividade regular e entregue às mãos de especialistas, e na modernidade - "Viveis em uma época em que tudo é moderno e novo” - menciona a Empresa Moderna de Reclame, colocando-se como aliada e promotora dessa modernidade, posicionamento semelhante que ocorreu com os publicitários ingleses, franceses e americanos. Devemos ter em conta que a arte moderna e a publicidade foram em suas origens contemporâneas, vivenciando as mesmas mudanças sociais e tecnológicas.

\footnotetext{
${ }^{5}$ Depoimento de Jean-Louis Fretin à autora, São Paulo, 24 maio de 2001. Na França, desde o século XIX o empresário/comerciante redigia ele mesmo o seu anúncio, ou solicitava a um desenhista um desenho. Para a construção de um projeto, ele se endereçava a um cartazista e/ou a um impressor. Para a difusão, para um pregador de cartazes, um jornal ou a um de seus representantes, os corretores. Consultar Marie-Emmanuelle Chessel, La publicité: naissance d'une profession 1900-1940, Paris: Éditions CNRS, 2002, p. 21.

${ }^{6}$ Observamos que foram muitos os escritos de intelectuais e jornalistas franceses que desde o final de 1920 à década seguinte combateram o poder de manipulação da publicidade, cometido pelo doutrinamento e pela intimidação, que culminou num anti-americanismo cultural. Idem, pp. 31-32.
} 
Esse amadorismo, fundamentado na atividade prática e que se identifica com o período dos reclames, conduz estudiosos e profissionais da área a não considerarem o que se produzia em nosso país, sobretudo nos vinte primeiros anos do século XX, como propaganda, ou seja, aquela implantada por uma sistematização de procedimentos e objetivos; por outro lado, os mesmos reconhecem a sua importância como fator determinante na constituição de um "modelo brasileiro". 7

Tal situação conflituosa nos estimula a indagar se a Empresa Moderna de Reclame e/ou a nossa propaganda estavam mesmo alinhadas, nos anos 20, às racionais técnicas publicitárias como se sugere nos Conselhos para vossa Reclame, definindo uma produção nacional de reclames modernos, não só enquanto emprego de ícones da modernidade, mas também em termos redacionais e gráficos. A propósito é oportuno observar que nesses anos as artes plásticas procuravam se configurar numa linguagem mais atualizada, “moderna”. Assim sendo, perguntamos se houve mesmo um diálogo entre estes distintos atores, ou seja, entre os publicitários e os artistas modernos.

De imediato, apresentamos o fato de não encontramos em nenhum momento da pesquisa, dentre as fontes da área publicitária consultadas, referências a nossa arte moderna e à participação de seus artistas na propaganda brasileira, sobretudo quando de debates e ações mais calorosas sobre o assunto, que circunscrevem-se nos anos de 1920 a 1930, e, tampouco menção a possíveis diálogos estéticos entre a arte publicitária e a arte moderna. Os nomes citados resumem-se àqueles artistas que se dedicam e se destacam na propaganda e não nas artes plásticas, com exceção dos caricaturistas. Só com a proximidade da década de 1950 é que detectamos uma abertura nesse sentido, proveniente principalmente do incentivo e acolhida que a propaganda recebeu do MASP. Somando-se a essa situação, as peças publicitárias dos artistas plásticos localizadas advêm, em sua maioria, de informações coletadas nos diversos meios informativos das artes plásticas e no encontro casual do manuseio de periódicos pesquisados e não na literatura da propaganda sobre e da época.

Para continuar respondendo às perguntas lançadas acima é necessário primeiramente configurarmos o campo publicitário desses anos, pois o exame da produção de reclames e das técnicas publicitárias por periódico, ultrapassa a nossa

\footnotetext{
${ }^{7}$ O termo "modelo brasileiro" refere-se aos tempos ingênuos do reclame. Sobre o assunto consultar Caio A. Domingues, "Modelo brasileiro de propaganda", Propaganda, São Paulo, XVII (208): 33-40, nov. 1973.
} 
proposta de estudo, visto a Empresa Moderna de Reclame $^{8}$ ser uma espécie de departamento de propaganda da revista A Cigarra que empregava fartamente a fotografia em suas páginas, até mesmo nos anúncios comerciais. Só esse fato a distingue de outras publicações do período. Além deste, devemos ter em conta que as revistas tinham seus diretores de arte e cada qual imprimia um perfil às suas edições, o que também poderia ocorrer com os anúncios, principalmente quando estes eram produzidos pelos profissionais da casa ou mesmo pelos seus diretores artísticos, a exemplo de Paim Vieira em Ariel. De modo geral, como veremos ao longo do estudo, essa situação, aparentemente mais flexível se mantém até a entrada no mercado das agências americanas, que irão impor progressivamente seus estilos à produção local.

No entanto, abrimos um parêntese, por julgar interessante mencionar a existência de alguns anúncios comerciais na revista A Cigarra que empregam a montagem fotográfica e são um diferencial na produção de reclames dos anos 1920 ELIXIR DE INHAME e sabão ARISTOLINO - ou tão somente a fotografia associada aos textos, como se verifica nos vários reclames testemunhais de produtos farmacêuticos, os quais desde a década anterior são bastante usuais. ${ }^{9}$ E, como contraponto ao descrédito conferido a publicidade, encontramos nas páginas desse mesmo periódico anúncios em forma de reportagens fotográficas, que ao invés de promoverem o produto, promovem a casa comercial e o seu proprietário. Trata-se de uma estratégia apoiada não diretamente, ou tão somente na eficácia da publicidade e sim na credibilidade da fotografia, que ao “documentar” o evento social, geralmente a inauguração ou reforma da loja, constrói e veicula uma imagem do comerciante associada ao ideário progressista que o mesmo ajuda a edificar, encobrindo o desejo deste por uma ascensão social.

Apesar de não confirmada, temos a informação de que teria sido a agência J. Walter Thompson (1929) a responsável pela introdução da fotografia nos anúncios, pois

\footnotetext{
${ }^{8}$ A Empresa Moderna de Reclames trabalhava articulada à revista A Cigarra, portanto não podemos confirmar se a empresa era ou não uma espécie de departamento de publicidade exclusivo do periódico. Informação encontrada em Heloísa de Faria Cruz, "A cidade do reclame: propaganda e periodismo em São Paulo - 1890/1915”, Projeto História, São Paulo, (13): 88, jun. 1996. Conforme consta na FIG. 2, a tabuleta A Cigarra informa que U. Moro seria um "concessionário da reclame”.

${ }_{9}^{9}$ Anúncios publicados respectivamente em A Cigarra, São Paulo, (193), 1922 e out. 1925. Quanto à produção de anúncios farmacêuticos tomamos a liberdade de remeter o leitor ao artigo de Silvana Brunelli Zimmermann, "Reclames testemunhais", Mimesis: ciências humanas, Bauru, 26 (2): 55-74, 2005.
} 
“até a sua chegada todas as ilustrações dos anúncios eram na base de desenhos". ${ }^{10} \mathrm{~A}$ fotografia publicitária limitava-se a fotos de objetos e produtos, porque os brasileiros se constrangiam em posar como modelos. Também, houve resistência dos fotógrafos, quase todos atuavam como retratistas, - à idéia de fotografar para a publicidade. E, mesmo quando a reprodução dos jornais tornou possível a utilização da fotografia, as agências se valiam de fotografias importadas, escolhidas em catálogos com modelos americanos.

Não obstante, a presença desses “departamentos de publicidade” na imprensa periódica, a principal figura publicitária da época era a do corretor/agenciador de anúncios, que desde os anos iniciais do século passado já existia entre nós, tal qual nos Estados Unidos, Alemanha, França e Inglaterra. ${ }^{11}$ Estes profissionais iniciaram-se com o interesse dos jornais em propaganda devido à necessidade de baratear o seu preço de venda em função do aumento do número de leitores. Prática que depois se estendeu às revistas, acompanhando, segundo Affonso A. de Freitas, o comércio da época

a princípio refratário a reclame de qualquer natureza, ao extremo de não se utilizar da vantagem oferecida pelas empresas jornalísticas, das clássicas vinte linhas de anúncio gratuitamente cedidas a cada um dos assinantes do jornal, acabou por adotar a propaganda pela publicidade periódica, fazendo inserir seus primeiros anúncios, mal redigidos e inestéticos, em linhas corridas, numa lastimável sovinice de espaço, na

\footnotetext{
${ }^{10}$ Renato Castelo Branco et alii, op. cit., p. 311. Essa informação nos causa um estranhamento, porém acreditamos que talvez ela faça referência ao uso da fotografia desvinculado da necessidade de transposição do desenho.

${ }^{11}$ Um breve explicação sobre o surgimento da corretagem, nos diz que "quase simultaneamente nos Estados Unidos e na França, apareceram as primeiras tentativas de separar dos meios de informação a atividade puramente informativa da atividade comercial que buscava os anúncios como forma de cobrir o déficit financeiro. No ano de 1841 Volney B. Palmer, nos Estados Unidos, e no ano de 1845 Charles Duveyrier, na França, se convertem em intermediários especializados em servir de ponte entre os periódicos diários e os empresários anunciantes, lançando assim as bases do que mais tarde será a agência de publicidade. A inovação de Palmer consiste em que ele não era um simples vendedor de espaços em periódicos (essa mediação já existia, os periódicos admitiam qualquer anúncio de qualquer procedência). O que ele conseguiu foi a exclusividade dos espaços publicitários de alguns periódicos, convertendo-se em agente ou corretor único deles e recebendo por cada anúncio que chegava as suas páginas uma comissão. O anunciante não pagava nada para Palmer, pois seus clientes eram os periódicos. Ele abriu caminho para o agente publicitário. Quanto a Duveyrier, a diferença é que este comprava em bloco os espaços publicitários dos periódicos, cobrando por conta dos anunciantes. Mas, com o aumento da concorrência foi necessário estipular exclusividade”. O passo definitivo para a conformação de uma agência de publicidade, se deu a partir de 1869, na Filadélfia, com a N. W. Ayer and Son, por esta exigir dos seus clientes tanto um contrato de prestação de serviços como também que a preparação dos textos publicitários fosse realizada pela própria agência. Consultar José Ramón Sánchez Guzmán, Breve historia de la publicidad, 2a ed, Madrid: Ediciones Forja, 1982, pp. 131-135.
} 
última coluna da página, e chegando a atualidade, a aparecer não raro, na primeira página nobre, numa caríssima ostentação e num luxo yankee de custosa reclame. ${ }^{12}$

Em depoimento, mas sem estabelecer datas, o publicitário Júlio Cosi comenta que:

o comerciante dava anúncios porque o corretor era um bom sujeito ou amigo de um político influente. Não havia o propósito de ampliar o negócio e promover vendas com propaganda. Consequentemente, os anúncios eram improvisados, paupérrimos e quase sempre em composição. $^{13}$

Esses pequenos escritórios de corretagem/distribuição de anúncios deram origem ao aparecimento entre 1913 e 1914 da primeira agência de propaganda, em São Paulo, a Castaldi \& Bennaton, tendo por fundadores João Castaldi \& Jocelyn Bennaton. A mesma entre 1918 e 1919 se transformaria em A Eclectica, tendo depois como sócios Eugênio Leuenroth e Júlio Cosi.

A Eclectica é considerada a primeira agência de propaganda brasileira organizada em moldes profissionais, ${ }^{14}$ como também a primeira a representar contas americanas, tais como a Ford Motor Co. e a Texaco. Entre seus principais anunciantes figuraram: sabonete Lux, Indústrias Matarazzo, guaraná Champagne do Zanota, Maizena Duryea, sabonete Eucalol, Loteria Paulista, Pirelli, Gillette Blades, entre muitos outros. Tida como uma espécie de “célula-mater” na propaganda brasileira, A Eclectica, propiciou a formação da primeira geração de profissionais qualificados não só

\footnotetext{
${ }^{12}$ Apud Maria Diva Vasconcelos Taddei, A imagem no anúncio de jornal 1850-1914, São Paulo: Faculdade de Arquitetura e Urbanismo da Universidade de São Paulo, 1977, p. 10. Dissertação de mestrado.

${ }^{13}$ Supomos que seja nos anos iniciais da década de 1920. Apud Genival Rabelo, Os tempos heróicos da propaganda: agências pioneiras, Rio de Janeiro: Empresa Jornalística PN S/A, 1956, p. 83.

${ }^{14}$ A Eclectica teve uma filial no Rio de Janeiro sob a responsabilidade de Leuenroth, enquanto a direção da matriz, em São Paulo, ficou com Cosi. Existe uma discussão em torno de qual teria sido a primeira agência de propaganda do país. Mas, pelos "registros existentes, a primeira, cronologicamente falando, terá sido a Empresa de Publicidade e Comércio, constituída em São Paulo, a 22 de abril de 1891 (mesmo ano da fundação do Jornal do Brasil), dirigida por Honório da Fonseca, antigo redator do Correio Paulistano”. De 1908, é a Edanee; de 1913 é a agência de Pedro Didier e Antonio Vaudagnoti; de 1915, a Sociedade Carioca de Propaganda e a agência de Valentim Harris. Entretanto, Júlio Cosi testemunha que Pedro Didier, Valentim Harris e também Bennaton e Castaldi seriam na realidade "agentes de publicidade”, ou seja, aqueles intermediários citados que levavam aos jornais anúncios e publicações. Ver Fernando Reis, “São Paulo e Rio: a longa caminhada”, in Renato Castelo Branco et alii, op. cit., pp. 302-303.
} 
por terem prestados serviços às agências americanas que se instalavam no país, sobretudo no eixo Rio-São Paulo, mas também por estes terem estabelecido suas próprias agências. ${ }^{15}$

A década de 20, apesar de contar com um número reduzido de agências de propaganda, como Agência Pettinati de Publicidade Ltda. (1920) e a A. D’ Almeida (1924), acompanhou as grandes empresas na formação de seus próprios departamentos de propaganda, que funcionavam como uma espécie de agência da casa: house organs, a exemplo da Mesbla, Casa Alemã, Mappin, Laboratório Daudt \& Lagunilla, Light, Laboratório Oliveira Jr., Sul América, General Electric, General Motors.

Quanto aos suportes, os jornais e revistas eram os veículos mais utilizados pela propaganda desse período. Mas, Cosi lembra que havia também

a publicidade "outdoor" que era feita de forma improvisada, quase beirando à picaretagem. Jornais em primeiro lugar; depois, painéis e cartazes, em bondes e na rua, panos de boca de teatros e de cinemas. $\mathrm{Na}$ parte dos anúncios luminosos, dominavam as caixas com vidros pintados e refletores internos. Havia os "slides" que naquela época também se projetavam nos teatros e nos cinemas, idênticos aos da televisão de hoje, com a diferença de que eram confeccionados com laminas de vidro e podiam ser coloridos. ${ }^{16}$

Reconhecendo as necessidades que a propaganda desses anos requeria para seu desenvolvimento, Cosi percebeu que não bastava ser intermediário de publicidade como agentes de jornais, era necessário vender serviços e não somente espaços, precisava “aparelhar e preparar uma organização publicitária: apresentar idéias, planos, esquemas, orçamentos, preparar textos, material tipográfico, clichês, matrizes e fotos”. ${ }^{17}$ Deveria caminhar pari passu com os veículos utilizados, pois, a bem da verdade, a publicidade não se limita tão somente às atividades do comércio, ela acompanha a evolução dos meios de comunicação.

\footnotetext{
${ }^{15}$ São eles, entre outros, Belmonte, Vicente Caruso, José Caruso, Peter H. Salms, Jairo Ortiz, Decelio Moura, Mario Guimarães, Romiti, Lanzara: Piacitelli, Pery Campos, Humberto Pace, Antonio Pinto, na arte; Origenes Lessa, Afonso Schmidt, Plinio Ribeiro da Silva, Dieno Castanho, Wilson Veloso, Oswaldo Moles, Edgard Leuenroth, Vicente Ancona Lopes, na redação; Otilio Polato, Salvador Cosi Pintaudi, José Soares Bairão, Waldomiro Freire de Castro, Rafael Azambuja, José Dias Ladeira, Voltaire Leuenroth, Antonio Herrera, Victor Hawkins, João Ferreira Fontes, e Cicero Leuenroth na produção e contato. Ver Genival Rabelo, op. cit., p. 85.

${ }^{16}$ Idem, p. 83. Nessas lâminas de vidro, as mensagens dos anunciantes eram veiculadas com letras escritas à mão.

${ }^{17}$ Fernando Reis, op. cit., p. 302.
} 
Em 1929, o jornal Fanfulla, traz em suas páginas um anúncio de A Eclectica, que elencava alguns requisitos a que a propaganda deveria corresponder para garantir sua eficácia, confirmando, assim, os novos rumos empreendidos por Cosi. Seriam eles: atrair a atenção do leitor, criar o desejo de possuir o artigo anunciado, convencer o leitor que o artigo possui determinada qualidade e induzí-lo a comprar a mercadoria. ${ }^{18}$ Esse corpo teórico, ainda que somente um esboço, deve crédito à emergente psicologia aplicada à produção e aos métodos comerciais, da qual a publicidade se serve para alavancar o reconhecimento público da profissão de publicitário. Amparando-se nesta ciência humana, a publicidade passa a ter sua imagem associada a uma prática séria, legitima e de especialistas, que, finalmente se consagra, nos anos 50, quando surge o primeiro curso de propaganda, responsável institucionalmente pela formação de um meio técnico.

No período de 1926-1930 instalou-se e permaneceu no Brasil a Divisão de Propaganda da General Motor, considerada “o verdadeiro berço da moderna propaganda comercial no Brasil”. ${ }^{19}$ Trata-se, portanto, de uma contribuição das mais importantes para o desenvolvimento da nossa publicidade, pois, foi, principalmente, por meio desse departamento que tomamos efetivamente contato com a técnica da propaganda comercial americana. Como escola prática, proporcionou aos seus profissionais o contato atualizado com manuais, catálogos, livros e revistas técnicas, bem como provas de anúncios, cartazes e folhetos oriundos da matriz em New York.

Outro acontecimento importante deu-se no ano de 1929, quando a agência J. Walter Thompson estabeleceu-se em São Paulo para atender à conta da General Motors, absorvendo, desta, quase todos os seus funcionários do departamento de propaganda. Rodolfo Lima Martensen considera-a como o maior núcleo formador de homens-de-

\footnotetext{
${ }^{18}$ Ver Fanfulla, San Paolo, 24 ottobre 1929, p. 5. "La propaganda efficace deve rispondere ai seguenti requisiti: attrarre l'attenzione del lettore, creare il desiderio di possedere l'articolo annunciato, convincere il lettore che questo articolo possiede determinate qualità, indurLo a comprare la merce. Para exemplificarmos a situação a nível internacional, a publicidade na França, até pelo menos os anos de 1930, apesar de dispor de vários órgãos representativos da classe, também enfrentava dificuldades em se legitimar perante o público geral, daí ter se amparado, entre outros, na psicologia, uma ciência que lhe emprestava uma metodologia racional para o seu reconhecimento.

${ }_{19}$ Apud Roberto Simões, "História da propaganda brasileira”, Propaganda, São Paulo, 26 (308): 74, fev. 1982. Esse depoimento de F. T. Orlandi deve ser examinado com cautela, pois o mesmo emprega a expressão "propaganda moderna" afirmando que assim o faz para distinguir o que aqui se fazia antes, sem planejamento e técnica. Como veremos adiante, Júlio Cosi não concorda plenamente com esse ponto de vista, pelo menos no que se refere ao jornal.
} 
propaganda, visto ter instituído o sistema de trainees em função da necessidade de formar e capacitar profissionais. ${ }^{20}$

Cosi nos fornece outra faceta dessa história, ao abordar a contribuição das agências americanas ao desenvolvimento do nosso mercado publicitário, pois

não se pode dizer até que ponto a chegada das agências americanas influiu no desenvolvimento da propaganda no Brasil, pois era já melhor compreendida a propaganda nessa época. Em primeiro lugar, porque quase todas elas foram formadas com elementos nossos, alguns já bastante experientes, publicitários esclarecidos, que acompanhavam todos os passos da publicidade em todo o mundo. O que essas agências trouxeram foi a estabilidade de um negócio, arquitetado sobre clientes certos, inspirando maior confiança aos próprios homens de propaganda, inclusive os artistas. Isso, sim, foi fruto da chegada das agências estrangeiras. Elas não estavam aqui nas horas angustiosas em que era um sacrifício heróico conseguir-se uma estereotipia. Não havia firmas: especializadas e tudo era feito "à moda da casa", por processos domésticos. Pode-se recordar que para recortar as estereotipias, a fim de adaptar os textos, evitando, dessa forma, novo cliché ou estéreo, sobretudo para os jornais de língua estrangeira, a Eclética mandou adaptar uma máquina de costura, transformando-a em uma serra tico-tico reforçada. Pode-se afirmar, sem receio de erro, que a chegada das agências americanas, apenas veio trazer novos elementos que vieram se juntar aos existentes. Um anúncio brasileiro de 1928, era tão bom quanto um anúncio americano da mesma data. Referimo-nos, é verdade, aos anúncios dos jornais, pois que os anúncios das revistas, na América, apresentavam um trabalho muitas vezes superior, como acontece até hoje, pois o campo é outro, e o número e o aparelhamento gráfico das revistas é como se sabe extraordinário, sendo certo, outrossim, que as mesmas se apóiam num grande número de anunciantes. ${ }^{21}$

Não obstante o nosso cenário publicitário ir se conformando por meio de uma americanização, existiu uma propaganda, batizada posteriormente como um "modelo brasileiro”, que coexistiu por algum tempo com esse exemplo importado. Caio A. Domingues nos explica que a nossa propaganda

somente seguiu um "modelo brasileiro" puro, ao tempo em que se dizia "reclame". Quando se começou a falar em media e copy, rough e layout, tal não se fez impunemente. Com esse jargão importamos também o modelo. Mas, nos tempos ingênuos do reclame é que a propaganda teve,

\footnotetext{
${ }^{20}$ Rodolfo Lima Martensen, “O ensino da propaganda no Brasil”, in Renato Castelo Branco et alii, op. cit., p. 33.

${ }^{21}$ Genival Rabelo, op. cit., pp. 88-89.
} 
talvez, o "seu modelo brasileiro". Tempos ingênuos e irreverentes dos quais sobraram exemplos de que muitos se lembram - outros não. ${ }^{22}$

Já o “estilo brasileiro de propaganda” referendado por Ricardo Ramos, fundamenta-se na freqüente utilização do verso e da rima, do humor popular mediado pela caricatura dirigida aos políticos e a política, pela irreverência à religião e ao sexo, características, que segundo o publicitário, souberam se manter na publicidade brasileira. $^{23}$

Um artigo de 1937, ao comentar sobre a presença de agências de propaganda internacionais no Brasil, nos aproxima da situação publicitária vigente, pois elas

dividiram o campo publicitário em praticamente dois campos: um, "amador", composto de "amadores" quase sempre ex-jornalistas fracassados, que entendiam de reclame, ou de comerciantes "experientes”, que continuavam a repetir, com pequenas variações de tom, a velha praxe do Elixir Nogueira - "Attesto que depois de vinte e um annos de horriveis soffrimentos fiquei completamente curado com meia dúzia de vidros do seu milagroso preparado" (firma reconhecida pelo tabelião, etc.) - e outro, technicamente educado, voltado ao estudo dos mercados, com uma experiente observação das reacções da sua reclame sobre o espírito publico, capaz de medir os indices economicos de sua influencia em todos os sectores do paiz.

A LU-GO-LI-NA continuou a ser anunciada com as quatro syllabas, o ELIXIR DE INHAME continuou a "depurar, fortalecer e engordar” ... o seu intelligente fabricante, [...]

Ás cousas continuam como estavam. Nem se poderia esperar que de um momento para outro, só porque alguns technicos começavam a fazer uma nova publicidade no Brasil, o caracter da nossa propaganda fosse alterado radicalmente na forma e no fundo. Mas a profunda differença entre a nova publicidade que surgia, e a outra, que ainda não tivera tempo material para sahir dos nossos jornaes e revistas, se revelou, com marcante distincção, na opinião do consumidor nacional, que dahi em deante passou, quase inconscientemente, a reservar ao annuncio scientificamente estudado uma attenção e uma consideração que as empresas souberam explorar vantajosamente, procurando distanciar-se cada vez mais do outro grupo, para mais directamente poderem conquistar a confiança do seu grande publico. ${ }^{24}$

\footnotetext{
${ }^{22}$ Caio A. Domingues, op. cit., p. 36.

${ }^{23}$ Sobre o assunto consultar Ricardo Ramos, Um estilo de propaganda, São Paulo: CBBA, 1983.

24 “A publicidade no Brasil”, O Observador: econômico e financeiro, Rio de Janeiro, 1 (12): 44-45, jan. 1937.
} 
Esse mesmo artigo demonstra a reação do público brasileiro diante da publicidade norte-americana

que invadiu nossos jornais e revistas talvez um pouco bruscamente, sem ligar por um período razoável de transição - e nem isso seria possível no caso! - as duas fases completamente diversas do processo da propaganda. O certo é que o nosso público não gostou daquela propaganda importada. E não a apreciou porque não a compreendia, porque não a percebia - tão diversos sem dúvida eram os dois ambientes para os quais se destinava, dominados por outros fatores psicológicos, outro critério social, uma diferente noção da vida e das coisas. A internacionalização do anúncio era impossível. Insistir na universalidade seria reduzir-lhe o prestígio, diminuir-lhe os efeitos e, consequentemente, os resultados práticos. O mesmo anúncio, o mesmo lay-out, com um perfeito slogan, capaz de produzir em Nova York ou em Chicago uma sensação invulgar (e o caso do It is Time To Re-Tire é bem característico) nem sempre conseguia atrair um distraído olhar do leitor brasileiro ou boliviano, que não podem perceber o sentido gráfico ou cultural daquele reclame.

Daí o motivo de ter a publicidade norte-americana, sobretudo no Brasil uma resistência passiva da maioria do povo que, não a entendendo, não lhe compreendendo a significação psicológica, não se identificava com os seus termos e, por conseguinte, não se deixava convencer pelo seu texto. $^{25}$

Frente a esses problemas “os main-offices de Nova York começaram a olhar com mais atenção os jornais brasileiros e acabaram, com raras exceções, a considerar que seus representantes do Rio e de S. Paulo estavam certos do seu critério e na sua concepção da publicidade, cuja maior garantia de êxito é um perfeito conhecimento psicológico do meio ambiente”. ${ }^{26}$

Fechando a década, é lançada a revista de circulação nacional O Cruzeiro (1928), que comportava inovações gráficas; fixa residência no Brasil o polonês Henrique Mirgalowski (Mirga) que irá criar inúmeros cartazes para anúncios em bondes, no ano seguinte funda-se a empresa Publix, especializada em outdoor. Na transição das décadas de 20-30, a propaganda também continuou se beneficiando dos aperfeiçoamentos dos serviços gráficos e da implantação do rádio como mídia de massa, que a partir de 1933 se populariza, aparecendo os spots, programas associados a marcas.

Em termos de agências, a N. W. Ayer \& Son (1931-1943) instala-se no Brasil para responder pela conta da Ford. É interessante notar que a Ayer possuía sua oficina

\footnotetext{
${ }^{25}$ Idem, pp. 42-43.

${ }^{26}$ Idem, p.45.
} 
tipográfica na Filadélfia, fazendo suas próprias composições com os melhores recursos da época. A propaganda da Ford vinha, muitas vezes, pronta dos Estados Unidos, já traduzida em português de Portugal. $^{27}$ Quando as campanhas eram feitas aqui, utilizavam-se de desenhistas free-lancers como Villin e Hartman. Outras agências se constituíram nesta década, mantendo-se quase sempre no Rio de Janeiro e em São Paulo, tais como: Empresa Nacional de Propaganda, de vida curta (1930), a Standard Propaganda S.A. (1933), a McCann-Erickson (1935), a Lever's International Advertising Service - Lintas, house agency da Lever (1931 e depois reaberta em 1937), a Grant Anúncios (1939), e a Empresa de Propaganda Época S. A. (1937) do austríaco Gerhard Orthof. ${ }^{28}$

Rio de Janeiro e São Paulo testemunham, respectivamente, em 1937, a formação das primeiras associações de classe: Associação Brasileira de Propaganda - (АВP) e a Associação Paulista de Propaganda (APP). Como incremento e suporte para os discursos da publicidade, surgem: a primeira coluna dedicada à propaganda (1930), assinada por Sylvio Behring nas páginas do jornal O Globo, as revistas especializadas Exitus (1932), Propaganda (1937-1939) e, em 1935, os livros Processos de propaganda de Lion de Araújo e Publicidade e Propaganda de Ernani Carvalho. Finalmente, em 1938, realiza-se no Rio de Janeiro o I Salão Brasileiro de Propaganda. Todos esses empreendimentos configuram um cenário publicitário que busca sua profissionalização e status.

Vale mencionar que se um profissionalismo publicitário no Brasil que adentra a década de 30 pode parecer tardio, mencionamos que na França, somente no ano de 1937 pela primeira vez a publicidade dispôs de um pavilhão autônomo numa exposição universal. Trata-se do Pavillon de la Publicité - Exposition Internationale des Arts et

\footnotetext{
${ }^{27}$ Gerhard Wilda menciona que a maioria dos clientes da Ayer "eram multinacionais que mandavam quase tudo pronto para nós. Às vezes até traduzido. Eles tinham um português trabalhando na agência”. Entrevista disponível no site http://www.dpto.com.br/historia/gerhard/entrev.htm. Aproveitamos para mencionar que não localizamos nenhuma crítica acentuada dos publicitários brasileiros a esse procedimento das agências americanas, já o meio publicitário francês, protestava pelo envio dos anúncios prontos, considerando uma tática americana de adestramento que nivelava os consumidores do planeta. Sobre a influência americana na publicidade francesa consultar 150 ans de publicité: collections du musée de la publicité, Paris: Union Centrale dés Arts Décoratifs, 2004, pp. 7273.

${ }^{28}$ Estima-se que, entre São Paulo e Rio de Janeiro, 56 agências estavam em funcionamento nessa década. Sobre o assunto consultar Fernando Reis, op. cit., p. 334.
} 
Techniques; a partir de então a publicidade francesa ganha fôlego e passa a impor o seu caráter racional. $^{29}$

No Brasil, a evolução das atividades publicitárias na década de 40 é considerada como conturbada e de difícil análise, pois conviveram um decréscimo significativo no movimento de anúncios com um empenho de ampliar os horizontes da propaganda, sobretudo no que se refere aos hábitos de consumo e da cultura norte-americana. ${ }^{30}$ Entretanto, em suas memórias, Rodolfo Lima Martensen menciona que o desenvolvimento da propaganda no Brasil nestes anos foi extraordinário com agências crescendo e se multiplicando o que gerou para a década seguinte uma deficiência de profissionais qualificados. Também, neste período, continuam as tentativas de disciplinar eticamente a propaganda, por meio de associações ou sindicatos. Em fevereiro de 1949, nasceu o convênio entre as principais agências de propaganda do país, fixando normas padrão para o seu funcionamento. Desse convênio sairia, tempos mais tarde, a Associação Brasileira de Agências de Propaganda (ABAP). No Rio de Janeiro, entre os anos de 1940-47 seria publicada a revista Publicidade. Definem-se nesse período os grandes nomes da ilustração, Mirga, Villin, Fritz Lessin e Jim Abercombie.

Novas diretrizes na década de 50 são tomadas para a profissionalização do publicitário, pois a

demanda de talento já afeito às técnicas de propagandas era bem superior à oferta de pessoal experimentado. Para continuarem assumindo sua função de convertedoras de problemas de marketing em soluções publicitárias, as grandes agências tiveram de montar um esquema de formação de novos profissionais. Foram recrutar candidatos entre os formandos das faculdades de economia, arquitetura, administração de empresas e outras, treinando-os depois no próprio exercício da profissão pelo processo de tentativa e erro. Eram os famosos trainees que estagiavam em todos os departamentos das agências e adquiriam, depois de um ou dois anos, uma boa noção panorâmica do negócio da propaganda.

$[\ldots]$

\footnotetext{
${ }^{29}$ Sobre o assunto consultar Marie-Emmanuelle Chessel, op. cit., pp. 183-210.

${ }^{30}$ Não podemos desconsiderar que na década de 40, a publicidade foi um campo fértil para a penetração das marcas norte-americanas como também para a integração pan-americana, o que pode ser sentido na publicação Seleções do Reader's Digest que contava com grande aceitação do público brasileiro. Para um aprofundamento sobre o assunto consultar Érica Gomes Daniel, "Nos intervalos da guerra: pan-americanismo e propaganda comercial no Brasil dos anos 40", Revista da ESPM, São Paulo, 10 (1): 44-55, jan. - fev. 2003.
} 
Entrou-se, então, na era do vedetismo, e os falsos valores começaram a aparecer, com sérios riscos para a eficiência e bom nome da propaganda brasileira. O mau gosto esparramou-se pelos jornais, pelas revistas, pelos pontos-de-venda, pelos cartazes de rua ..... ${ }^{31}$

Pietro Maria Bardi, considerando essa situação comprometedora da nossa arte publicitária, resolveu realizar um salão de propaganda com o objetivo de demonstrar “que já existia publicidade de bom nível no Brasil e que ela deveria servir de exemplo aos improvisadores de mau gosto”, 32 Esse gosto duvidoso e a disparidade de concepção visual - artística e gráfica - podem ser sentidos em dois anúncios ilustrados, um da COCA-COLA [Fig. 23, 1943] e outro da CASA LuTZ FERRANDO [FIG. 25, 1949], que são, se comparados, dois extremos conflitantes da década de 40, porém indicativos da convivência do modelo técnico americano e de uma propaganda com uma qualidade plástica menos elaborada. Colabora para essa presença de reclames “duvidosos” a interferência do cliente, quando este escolhe e aprova determinado projeto em detrimento de outro mais criativo.

Paralelamente ao reconhecimento da importância da técnica americana “experimentada, científica e organizada” - por ocasião do Salão Nacional de Propaganda notou-se uma preocupação em afirmar uma produção livre das influências norte-americanas, porém afinada às nossas exigências locais, que podem ser encontradas nos cartazes para a empresa Olivetti de Leopold Haar e nas peças publicitárias de profissionais como Gerhard Wilda, Géza Kaufmann e Jorge Rado. ${ }^{33}$

Em decorrência deste evento, Bardi propôs a Rodolfo Lima Martensen a organização de um curso de arte publicitária no Instituto de Arte Contemporânea do Museu, para melhorar o nível artístico da nossa publicidade. Apoiando-se na realidade brasileira daqueles anos, marcada pelo grande desenvolvimento industrial, e a carência de uma estrutura publicitária eficiente, Martensen concluiu que o que deveria ser realizado não era "um simples curso de arte publicitária e sim de uma completa Escola

\footnotetext{
${ }^{31}$ Rodolfo Lima Martensen, Desafio de quatro santos: memórias, São Paulo: LR Editores, 1983, p. 279.

${ }^{32}$ Idem, p. 280. A exposição ocorreu em dezembro de 1950 no saguão do Edifício dos Diários Associados, local onde funcionavam o Museu de Arte. Participaram do Salão, entre artistas e diretores de arte Rubens de Albuquerque Vaz, Hans Gunter Flieg, Fred Jordan, Hermelindo Fiaminghi, Milton Brescia, Geraldo F. Wilda, J. G. Villin, Jorge Rado, Henrique Mirgalowski, Fritz Lessen, Vicente Caruso, Dona Carlota, Géza Kaufmann e José Caruso. Encontramos controvérsias quanto ao nome do evento, pois a revista Habitat, São Paulo, (2): 45, jan. - mar. 1951, refere-se a ele como $1 .^{0}$ Salão de Propaganda.

${ }^{33}$ Esses trabalhos encontram-se reproduzidos no artigo supracitado da revista Habitat.
} 
de Propaganda” ${ }^{34}$ O primeiro curso foi lançado em março de 1952 e foi a semente da Escola Superior de Propaganda e Marketing (EsPM).

Pelo quadro exposto até agora, São Paulo e Rio de Janeiro foram os dois estados que saíram à frente no cenário publicitário do país. Nos demais, com poucas exceções, o processo de implantação de uma publicidade sistematizada e organizada nos moldes alcançados pelos dois exemplos citados, só ocorrerá na década de 1950 em diante. ${ }^{35}$

\footnotetext{
${ }^{34}$ Idem, p. 281.

${ }^{35}$ Sobre o desenvolvimento da propaganda nos demais estados brasileiros indicamos ao leitor os últimos capítulos do título História da propaganda no Brasil de Renato Castelo Branco et alii, em função de o assunto extrapolar os limites temporais propostos neste estudo.
} 


\subsubsection{EVOLUÇÃo DOS ANÚNCIOS COMERCIAIS}

Se de repente suprimíssemos todos os anúncios dos jornais, das revistas, estações de rádio, paredes velhas, bondes, ônibus, carros de estradas de ferro; se nossos olhos pudessem repousar à noite sem o pisca-pisca luminoso dos arranha-céus, forçando-nos a pensar em sabonetes, chapéus, vinhos, produtos farmacêuticos e tanta coisa mais, penso que todos nós sentiríamos no nosso íntimo uma espécie de desequilíbrio, sentiríamos a falta de qualquer coisa mais ou menos como a falta do cigarro para o fumante ou simplesmente a xícara de café habitual depois das refeições. ${ }^{36}$

Tarsila do Amaral

Consenso se fez e se manteve ao longo dos anos entre especialistas da área, tais como Ricardo Ramos, Roberto Simões e Ricardo Oberlaender, no reconhecimento de duas grandes linhas divisórias na propaganda brasileira, guiadas preponderantemente por dois distintos modelos, respectivamente estabelecidos em valores artístico e técnico:

- o europeu que de certo modo perdurou até a segunda década do século XX. Nele se destacam referências francesas, entre as mais significativas figuram: o sistema de anúncios classificados, instituído pelo francês Pierre Plancher $(1824)^{37}$ em duas publicações cariocas notadamente comerciais - Spectador Brasileiro e o Almanak dos Negociantes; a publicação de muitos anúncios em francês; e, o estilo Art Nouveau, presente nos reclames desde o século XIX.

\footnotetext{
${ }^{36}$ Trata-se do artigo "Anúncios” de 10 abr. 1941, apud Aracy Amaral, Tarsila cronista, São Paulo: Editora da Universidade de São Paulo, 2001, p. 162. Anúncios está muito próximo das frases empregadas por Blaise Cendrars em seu texto Publicité = poésie, dedicado a Cassandre. ${ }^{37}$ Exilado no Brasil, o editor e jornalista francês, Pierre René François Plancher de la Noé, foi o Impressor Real à época do Primeiro Reinado. E, responsável também pela publicação dos periódicos Diário Mercantil e Jornal do Commercio.
} 
- o americano que se segue ao modelo anterior, fortalecendo-se a partir da década de 1930, em função da instalação das agências americanas em São Paulo e no Rio de Janeiro. ${ }^{38}$

Essa divisão torna-se problemática quando pensada em termos iconográficos, pois na década de 30, o cenário publicitário brasileiro convivia não somente com a arte publicitária produzida pelas agências de propaganda norte-americanas instaladas em solo brasileiro, mas também com o estilo Art Déco e com aquela produzida pelos profissionais das artes gráficas formados em centros europeus, entre os mais conhecidos: o cartazista Mirga que esteve à frente da Cia. dos Anúncios em Bondes, Gerhard Orthof, Geza von Puttkamer (Barão Puttkamer), erico e Gerhard Wilda, um dos primeiros diretores de arte do Brasil.

De modo geral, os estudos históricos da publicidade brasileira que procuram acompanhar as transformações ocorridas em seus reclames, detêm-se principalmente na análise da mensagem comercial ancorada nas redações do título, do texto central e do slogan da propaganda, o que, por sua vez, conduz ao rememorar das marcas e dos lançamentos dos produtos no decurso das décadas. Esta conduta acaba por diluir o interesse pela evolução da imagem publicitária.

Nossa pesquisa verificou que nada mais incorreto e distante da realidade do que considerar que os anúncios comerciais evoluíram abandonando completamente as suas formas antigas de representação, pois o acompanhamento do desenvolvimento da propaganda de produtos e empreendimentos por décadas, demonstrou uma convivência de expressões estilísticas e uma extensão temporal de determinados produtos e, portanto de suas mais conhecidas propagandas. Assim, encontramos os mesmos anúncios, às vezes com poucas variações, dos primeiros anos do século passado em décadas seguintes, a exemplo dos medicamentos Lugolina e do Elixir de Mururé Caldas. Essa presença pode ser justificada como uma estratégia adotada pelos laboratórios farmacêuticos nacionais para reafirmar a qualidade de seus produtos que há anos se mantêm no mercado e também para não deixá-los caírem no esquecimento visto a concorrência com as empresas multinacionais. Por outro lado, notamos que um expressivo número de reclames da década de 1920 se mantém próximo ao estilo daquelas propagandas produzidas nos vinte anos anteriores. Essas ocorrências

\footnotetext{
${ }^{38}$ Igualmente, devemos ter em conta que a década de 40 foi fortemente marcada, por meio da propaganda, pela cultura e empresas norte-americanas.
} 
verificam-se mais facilmente nos conhecidos classificados, que desde meados dos oitocentos foram sofrendo modificações, seja no aumento de seu tamanho, nas vinhetas e ilustrações que receberam [FIGs. 5, 6, 7, 10], seja no uso freqüente dos versos rimados e elaborados, muitos deles, pelos poetas humoristas da Belle Époque carioca [FIG. 13]. Esses profissionais das letras, além de avalizarem os produtos e serviços anunciados, também os popularizaram pelo tom irreverente da mensagem que mais diretamente e eficazmente consegue atingir uma população dominada pelo analfabetismo, e que encontrava no exercício da repetição o auxílio para memorizar os reclames e consequentemente os produtos.

Em função do exposto, inviabiliza-se a elaboração de rígidas categorias de anúncios comerciais ilustrados que pudessem estar ao mesmo tempo em sintonia com um desenvolvimento cronológico e com os novos valores redacionais e gráficos que a publicidade inseria no mercado, sejam eles advindos das contribuições européias e/ou americanas. Um outro elemento que dificulta o nosso estudo iconográfico, mas que deve ser levado em conta é o fato de alguns anúncios virem prontos das matrizes das agências americanas ou então serem adaptações de propagandas estrangeiras, a exemplo da Emulsão de Scott.

Obedecendo ao arco temporal que nos interessa e sem pretender esgotar as possibilidades mesmo porque seria inviável frente não só a diversidade de anúncios, mas, também, pelo significativo número de periódicos existentes, optamos por eleger uma produção de anúncios comerciais ${ }^{39}$ que reunisse em si um número adequado de características formais que consideramos representativas da propaganda do período e oportunas ao nosso estudo por servirem de apoio e comparação quando do exame, no último capítulo, das peças publicitárias produzidas pelos diversos artistas plásticos e gráficos, ilustradores e caricaturistas; dentre elas constam: as mais usuais, as representativas de estilos artísticos europeus, as que podem ser consideradas como tipicamente locais e que também de algum modo dialogam com a nossa modernidade, e outras que permitem um reconhecimento e um cotejamento entre os modelos europeus e os americanos.

\footnotetext{
39 Propositadamente, não incluímos neste mapeamento a produção dos artistas plásticos selecionados no capítulo III, pois nem sempre as suas peças publicitárias se encontravam em revistas de grande circulação, o que as torna de pouca expressividade no conjunto, porém este fato não diminui seus valores artísticos. Nossa intenção é que elas sirvam como contraponto a essa produção de massa. Um outro motivo de não apresentá-las nesse momento é que muitas delas permaneceram na forma de projetos.
} 
Definida a nossa estratégia, têm-se que nos reclames do final do século XIX, prevalece o texto informativo, a exemplo dos anúncios que noticiam e/ou agregam virtudes ao produto e que vez ou outra incorporam uma ilustração [FIGS. 3, 8, 9], ou ainda aqueles que procuram convencer por meio de explicações de suas vantagens, empregando adjetivos, como admiravelmente, o melhor, o mais eficaz.

Na virada do século e nas suas duas primeiras décadas, encontram-se com mais freqüência os anúncios ilustrados, às vezes ocupando páginas inteiras, geralmente e dependendo da publicação, as segundas e quartas capas das revistas, muitos dos quais a duas cores e que da mesma forma podem ser encontrados, ainda que façam uso de longos textos, no formato cartaz [FIG. 4]. ${ }^{40}$ Também é nesse período que os anúncios fartamente aplicam o estilo Art Nouveau [FIGS. 170, 171]. Na linguagem caricaturesca, destaca-se o uso de políticos na propaganda [FIG. 137]. Irreverência e humor estão presentes na produção desses anos e mesmo em anos posteriores [FIGS. 11, 12, 14, 174].

A preocupação dos desenhistas, ilustradores e até mesmo dos caricaturistas estava voltada para o embelezamento da imagem e estes profissionais se restringiam a executar o essencialmente artístico, não incorporando em seus trabalhos estratégias visuais e psicológicas subliminares que induzissem o leitor a se interessar ou mesmo a comprar o produto anunciado, e quando não era a poesia que predominava, era a longa explicação. Este caráter utilitário da propaganda - que tanto pode ser o argumentativo quanto o persuasivo - só se adensa quando a publicidade passa a ser uma atividade organizada e metódica e, quando o talento do artista transpõe a confecção de um bom desenho e encaminha-se para a produção do layout, assumindo-se como um artista publicitário; momento este que pode ser mais bem compreendido quando Licurgo Costa, em 1940, explica as razões do desenhista, ou seja, do artista ser a orientação preponderante na publicidade moderna e não o escritor, pois é ele “que dá corpo à idéia central do anúncio e que, portanto lhe dá o interesse que atrai a atenção do leitor. E poderemos dizer, sem medo de errar, que nesta fase é que o desenho entrou na publicidade definitivamente”. ${ }^{41}$

\footnotetext{
${ }^{40}$ Geralmente as duas cores eram verde e azul, amarelo e vermelho, roxo e amarelo. O cartaz do Xarope São João encontra-se reproduzido em Ricardo Maranhão (coord.), Um retrato no jornal: a história de São Paulo na imprensa oficial (1891-1994), São Paulo: Imprensa Oficial do Estado, 1994, p. 58.

${ }^{41}$ Licurgo Costa, “O dezenho em função da publicidade na imprensa moderna”, Publicidade, Rio de Janeiro, (s.n.): 26, set. 1940.
} 
Se a passagem da propaganda empírica para a racional coincide com o nosso modernismo artístico, indagamos se houve empréstimo deste na produção dos anúncios comerciais, se a arte publicitária foi considerada pelos modernistas como uma nova expressão estética. Observamos que, diferentemente do que se sucedeu na Europa, na década de 1920 a propaganda brasileira que bem poderia ter empregado os artistas plásticos que despontavam na nossa arte moderna, não o fez com entusiasmo; são parcerias tênues que se estabeleceram individualmente, muito provavelmente em função de vínculos profissionais já existentes com a imprensa, a exemplo de Di Cavalcanti. Se essa parceria é rarefeita nas artes plásticas o mesmo não ocorre com os escritores modernistas, a exemplo dos anúncios zombeteiros publicados pelo grupo na revista Klaxon. $^{42}$

Nos anos 30, encontra-se uma grande variedade de gêneros de anúncios. De modo geral, diminui significativamente a presença do anúncio caricaturado, porém quando encontramos anúncios concebidos pelos caricaturistas, são eles ilustrações não ancoradas na linguagem caricaturesca, a exemplo dos muitos trabalhos publicitários de J. Carlos e de Seth. Numeroso é o desenho a traço, que procura representar não só a imagem do produto, mas igualmente a narrativa visual do anúncio; por outro lado se adensa a presença do Art Déco [FIGs. 15, 16] sobretudo nas figuras femininas ligadas à moda e seus artefatos e mantêm-se aqueles anúncios que marcaram época e que desde o século passado são empregados sob readaptações [FIGS. 17, 154, 169]; de fato, são propostas contrastantes para o período, mas que pelo humor teimam em permanecer como uma formulação de sucesso. Por final, verifica-se a presença dos anúncios de produtos americanos, tais como canetas e carros, que pela suas concepções visuais mais técnicas e padronizadas se diferenciam claramente de outras artes publicitárias [FIGs. $18,19,21,22,23,24]$.

Diferentemente da produção européia que é mais artística, por investir na abstração e na representação de objetos e símbolos [FIGS. 20, 208], no uso mesmo de alegorias, a iconografia publicitária dos anúncios americanos se assenta no realismo visual, daí a sua preferência pela fotografia que "mostra o produto”, e na argumentação em diversos planos. ${ }^{43}$ A nosso ver, estas constatações podem estar relacionadas ao fato

\footnotetext{
${ }^{42}$ Esse assunto será aprofundado no capítulo seguinte, quando também aproveitaremos para comentar dois anúncios da revista Klaxon, PANUOSOPHO, PATEROMNIUM \& CiA. e Aviso Á PraÇA.

${ }^{43}$ Esclarecemos que no decurso dos anos 20, na Alemanha, desenvolveu-se uma pesquisa sobre a utilização conjunta da fotografia "pura" e da tipografia direcionada à publicidade (typo-
} 
da primeira ter fortes vínculos com a cartazística, com a mensagem relâmpago que não tem por função argumentar e sim emitir uma idéia, associando um nome ou um personagem típico a uma imagem (marcas), enquanto a segunda vincula-se ao anúncio, ou seja, de eficácia direcionada ao argumento, portanto mais redacional, dizendo “unicamente aquilo que quer dizer”. Se os anúncios europeus do período que aplicam uma estética moderna emprestada das vanguardas artísticas são difíceis de serem compreendidos pela massa consumidora, os “quadros vivos” americanos possibilitam maior entendimento e transformam os indivíduos em consumidores perfeitos.

Na década seguinte o modelo americano e seus produtos se afirmam nas páginas de nossas revistas, e com este entra em cena um estilo novo de mulher, a pin-up, ${ }^{44}$ “estrela anônima inspirada no cinema americano. Alegre com um sorriso brilhante, sã, tônica, frequentemente esportiva, jamais sofisticada, acessível, atraente, esperta sem vulgaridade, ela desempenha perfeitamente seu papel de vetor do desejo”. ${ }^{45}$

Para responder àquela nossa inquietação inicial é necessário primeiramente mencionar, como vimos, que a publicidade moderna brasileira provém e está associada aos métodos racionais norte-americanos que foram sendo implantados em nosso meio, sobretudo, a partir da década de 30, o que não necessariamente corresponde, dentro do período selecionado, a uma arte publicitária - em termos iconográficos e tipográficos fundamentada em soluções formais das vanguardas históricas ou de outros movimentos artísticos modernos. Decorrente desse fato, não acreditamos que a Empresa Moderna de Reclame tenha se adiantado nessa dupla modernidade. Basta observar, por um lado, as características artísticas das tabuletas dos "homens-reclame”, e, por outro, as informações que elas veiculam sobre os serviços da empresa: a execução de letreiros, croquis e reclame [FIG. 2], o que denota um distanciamento das práticas publicitárias racionais.

Assim sendo e mesmo inseridos numa modernidade publicitária, nossos anúncios nem sempre foram imagens comprometidas com o vocabulário moderno, pelo menos é o que pudemos observar nas revistas de grande circulação. Por outro lado e em menor número destacam-se a produção dos artistas plásticos voltada para a publicidade

photo), a exemplos dos trabalhos de Max Burchartz, El Lissitzky e Mart Stam, que estão na base da Nova Tipografia (1925) enunciada por Laszlo Moholy-Nagy.

${ }^{44}$ As pin-ups foram criadas pelo peruano Alberto Vargas e sua primeira aparição foi na revista Esquire em 1940. Consultar Juan Carlos Pérez Gauli, El cuerpo em venta: relación entre arte y publicidad, Madrid: Cátedra, 2000, p. 168.

${ }^{45} 150$ ans de publicité: collections du musée de la publicité, op. cit., p. 72. 
nas revistas de circulação intelectual dos anos 20-30, que apesar de também não corresponderem em seu conjunto, exatamente a uma modernidade estética formal, são bons exemplares de anúncios artísticos e, sem camuflagem, revelam o que verdadeiramente circulava e se produzia iconograficamente no período. 
Capítulo 2

MERCADO de tRABALHO 
Um dia desta semana, farto de vendavais, naufrágios, boatos, mentiras, polêmicas, farto de ver como se decompõem os homens, acionistas e diretores, importadores e industriais, farto de mim, de ti, de todos, de um tumulto sem vida, de um silêncio sem quietação, peguei de uma página de anúncios e disse comigo:

- Eia, passemos em revista as procuras e ofertas, caixeiros desempregados, pianos, magnésias, sabonetes, oficiais de barbeiro, casas para alugar, amas de leite, cobradores, coqueluches, hipotecas, professores, tosses crônicas ... ${ }^{1}$

Machado de Assis

${ }^{1}$ Apud Roberto Simões, “História da propaganda brasileira”, Propaganda, São Paulo, 26 (308): 59, fev. 1982. 


\subsection{COMPOSIÇÕES ENTRE O LÁPIS E A PENA NA PROPAGANDA BRASILEIRA}

Olavo Bilac em uma de suas crônicas chegou a predizer que se aproximava

o dia em que soará para os escritores a hora do irreparável desastre e da derradeira desgraça. Nós, os rabiscadores de artigos e notícias, já sentimos que nos falta o solo debaixo dos pés ... Um exército rival vem solapando os alicerces em que até agora assentava a nossa supremacia: é o exército dos desenhistas, dos caricaturistas e dos ilustradores. O lápis destronará a pena: ceci tuera cela.

Já ninguém mais lê artigos. Todos os jornais abrem espaço às ilustrações copiosas, que $[* * *]$ pelos olhos da gente com uma insistência assombrosa. As legendas são curtas e incisivas: toda a explicação vem da gravura, que conta conflitos e mortes, casos alegres e casos tristes.

O poeta finaliza, concluindo que, no jornalismo do Rio de Janeiro,

já se iniciou a revolução, que vai ser a nossa morte e a opulência dos que sabem desenhar. Preparemo-nos para morrer, irmãos, sem lamentações ridículas, aceitando resignadamente a fatalidade das coisas, e consolando-nos uns aos outros com a cortesia de que, ao menos, não mais seremos obrigados a escrever barbaridades...

Saudemos a nova era da imprensa! A revolução tira-nos o pão da boca, mas deixa-nos aliviada a consciência. ${ }^{2}$

Trinta anos mais tarde a Revista do Globo publicaria em seu editorial:

\section{Elogio da Revista}

- E em matéria de literatura?

Eu prefiro a revista. A revista, meu caro, é o manual mais barato da criatura inteligente. É na revista que este mundo gira. Com hemisférios e tolices. É na revista que a sua mão folheia o previtismo universal.

Primeira página, os anúncios. E o poeta que mandou seu poema comovido, em lugar de revê-lo numa página inteira vinhetadíssima e

\footnotetext{
${ }^{2}$ Ver Olavo Bilac, Vossa insolência: crônicas, São Paulo: Companhia das Letras, 1996, pp. 165-166 e 170. Trata-se da crônica "Fotojornalismo" publicada originalmente no jornal Gazeta de Notícias, Rio de Janeiro, 13 jan. 1901.
} 
ilustrada, vai encontrá-lo ali na página de anúncio, entre o reclame de um guaraná e o cartaz enquadrado de um novo filme americano. ${ }^{3}$

Aparentemente, essas duas citações, indicam que os literatos estariam perdendo espaço na imprensa, ora para os desenhistas do lápis, ora até mesmo para os anúncios comerciais. Seria isso mesmo? E, também seria o caso dos desenhistas, dos caricaturistas e dos ilustradores terem seus espaços consagrados nas revistas ilustradas invadidos e/ou substituídos pela publicidade? Sim e não. Acreditar que esses homens teriam “cedidos” seus nichos de produção para possíveis concorrentes ou mesmo, como no caso dos literatos, para "um exército rival”, segundo a expressão de Bilac, seria tomar como ponto de partida uma visão se não no todo, em parte, inexata. Portanto, à parte de conclusões apressadas, esses dois testemunhos se revestem de importância por permitirem um exame sobre o campo de trabalho desses grupos de profissionais.

A citação de Bilac, por um lado, é um ligeiro e disfarçado apontamento sobre a crise intelectual e moral da imprensa, que assumia um caráter empresarial. E, por outro lado, o que dela o poeta procura colocar em evidência é o reclamo das mudanças que estavam ocorrendo no âmbito de atuação dos homens das letras nas décadas iniciais do século XX, estas decorrentes, significativamente, mas não unicamente, dos novos incrementos de impressão e de edição gráficas. Paralelamente a esse processo, as transformações sociais e culturais que o acompanham, passam a exigir do literato um novo modo de aproximação a esse público letrado: a burguesia urbana, ávida pelo consumo das revistas ilustradas e também pelo “novo jornalismo”.

Nicolau Sevcenko acredita que houve no período da Primeira República um processo de banalização e neutralização ou mesmo um achatamento da força cultural da literatura, e, por conseguinte uma perda progressiva do gosto literário. ${ }^{4}$ Portanto, o "novo jornalismo" que abarcou um grande número de intelectuais que se tornaram jornalistas assalariados, constituía-se dispensando as longas crônicas por apostar numa linguagem menos rebuscada, numa comunicação sucinta e padronizada, ao mesmo tempo em que explorava o uso da ilustração e da fotografia, como denuncia Bilac em

\footnotetext{
${ }^{3}$ Editorial assinado por Theodomiro Tostes. Consultar Revista do Globo, Porto Alegre, 50 (2): 10, 17 jan. 1931.

${ }^{4}$ Nicolau Sevcenko, Literatura como missão: tensões sociais e criação cultural na primeira república, $2^{a}$ ed., São Paulo: Companhia das Letras, 2003, pp. 123-124. Sugerimos também a leitura das páginas 117 a 137, para um aprofundamento sobre a crise da literatura ocorrida na Primeira República.
} 
sua crônica. ${ }^{5}$ Todavia, parece-nos que o poeta, neste particular, exagera ao projetar para o futuro o desaparecimento dos cronistas e noticiaristas, pois Bilac não se apercebe ou então desconsidera propositadamente, para dramatizar ainda mais a precária situação dos escritores, a estratégia comunicacional que se estabelece entre o discurso textual e a imagem, sendo que ambos se tornam, não só potencializadores um do outro, mas imprescindíveis um ao outro.

Analisando e cotejando a crônica de Bilac com o que foi produzido nas décadas subseqüentes, e afora as práticas tradicionais do jornalismo, verifica-se que o príncipe dos poetas no início do século passado não previu a relação profícua entre os desenhistas do lápis e os homens das letras, particularmente a atuação destes na caricatura e na propaganda. Se de um lado existia a concorrência, por outro existiam as parcerias, orientadas, sobretudo pela inexistência no mercado de profissionais específicos. $^{6}$

Se a crise da literatura e a fragmentação da intelectualidade são problemas que se configuraram nas primeiras décadas do século XX, Sevcenko também nota que a dessacralização do literato vai mais longe frente às novas demandas do mercado, chegando ao ponto da

mercantilização da própria literatura como matéria bruta em si, desprendida da originalidade de qualquer autor. É o caso, por exemplo, de A Agência Literária, que se dispunha a fornecer, mediante a devida encomenda, “discursos parlamentares, conferências literárias e artigos de crítica literária sobre qualquer obra”. Ou mais curiosamente ainda, o concurso do Chocolate Lacta, que oferecia 500 mil-réis pelo soneto

\footnotetext{
${ }^{5}$ A crônica "Fotojornalismo" é uma crítica ao uso crescente da fotogravura no jornalismo em detrimento do texto. Sem contar com o ganho em qualidade gráfica das revistas ilustradas, a introdução da fotografia na imprensa altera ou mesmo rompe com os modos de representações precedentes, não só por apostar numa informação e documentação mais fidedigna, mas também por "industrializar" a imagem. Deste modo, as queixas de Bilac procedem, visto que a imagem fotográfica, tida como testemunho e duplo da realidade, acaba por ocupar os espaços antes destinados aos exercícios e análises dos homens da pena, o que será determinante para o surgimento do repórter, diferenciando assim a literatura do jornalismo. É preciso acrescentar que, no período em questão, os desenhistas da imprensa além de realizarem ilustrações e caricaturas, muitas vezes, eram também os supervisores ou responsáveis pelo processo de transferência da imagem fotográfica para os clichês.

${ }^{6}$ As transformações ocorridas, sobretudo ao longo das primeiras décadas iniciais do século passado na imprensa brasileira, já foram estudas por vários autores, como: Nicolau Sevcenko, Elias Thomé Saliba, Sergio Miceli, Ana Luiza Martins, Monica Pimenta Velloso e Ana Paula Cavalcanti Simioni. Mesmo que sob enfoques distintos, eles são unânimes ao destacar a importância do convívio entre os artistas do lápis e os escritores, seja nas redações da imprensa ou mesmo fora dela, para a constituição de um "capital de relações sociais" que é fator determinante para as trocas e ajudas mútuas, principalmente, no campo profissional.
} 
decassílabo ou alexandrino "que, pela perfeição, apuro de forma, sugestão e pela maneira com que puser em evidência o sabor e as qualidade nutritivas do Lacta, for considerado o melhor”. 7

Apesar dessas últimas observações acerca do mercado de trabalho literário serem dirigidas às décadas iniciais do século passado, a participação dos escritores na confecção dos reclames iniciou-se muito antes com o poeta Casimiro de Abreu ${ }^{8}$ quando da redação de anúncios para o estabelecimento carioca À Fama do Café-com-Leite, cujos versos foram publicados numa coluna paga do jornal Correio Mercantil no carnaval de $1858 .{ }^{9}$ Do mesmo modo, um anúncio publicado na revista A Semana, em seu número de janeiro de 1885, dava a ver sobre as formas literárias que já eram usuais nos anos finais dos oitocentos:

\section{RECLAMES}

Publicam-se n'esta folha reclames comerciais sob a forma de contos, poesias, notícias, etc. Verdadeiras armadilhas, agradáveis e infalíveis à atenção do leitor. Preços variáveis, conforme a natureza e o tamanho do reclame e mediante prévio ajuste no escritório da folha - Travessa do Ouvidor, n. ${ }^{0} 36$, sobrado. ${ }^{10}$

Essas ocorrências nos conduzem a acreditar que já existia um canal aberto entre os escritores e os comerciantes ou mesmo entre aqueles e os agenciadores de anúncios, provavelmente devido às relações de amizade, à necessidade de ganhos suplementares e

\footnotetext{
${ }^{7}$ Nicolau Sevcenko, op. cit., pp. 128-129. O certame da Lacta foi divulgado nas páginas da revista Fon-Fon, em 24 de maio de 1919. Essas verdadeiras estratégias propagandísticas já vinham ocorrendo em anos bem anteriores, pois em 1909 e 1911 o Laboratório Daudt \& Lagunilla promoveu os primeiros concursos de cartazes no Rio, tendo os caricaturistas concorrido em número significativo, a exemplo de Luiz Peixoto, Julião Machado, Arthur Lucas, K. Lixto, Raul, Vasco Lima e outros. Em 1915, a Usina São Gonçalo, fabricante de doces e vinhos de frutas, também promoveu um concurso de cartazes do qual participaram Germano Neves, Amaro Amaral, Raul, Mario Tullio e outros. Sobre este último, consultar Orlando da Costa Ferreira, Imagem e letra: uma introdução à bibliologia brasileira: a imagem gravada, $2^{a}$ ed., São Paulo: Editora da Universidade de São Paulo, 1994, p. 443.

${ }^{8}$ Segundo Ricardo Ramos, Um estilo de propaganda, São Paulo: CBBA, 1983, s.p.

${ }^{9}$ O anúncio OFERECIDO E DEDICADO À FAMA DO CAFÉ-COM-LEITE, EM ATENÇÃO À DESPEDIDA DO CARnAVAl, encontra-se na íntegra em Raimundo Magalhães Jr., Poesia e vida de Casimiro de Abreu, $2^{\underline{a}}$ ed., São Paulo: Lisa; Rio de Janeiro: INL, 1972, pp. 85-87. Essa anterioridade também se confirma, em 1890, com a propagação de anúncios comerciais em forma de textos literários na revista paulista $\mathbf{O}$ Cenáculo, que foram concebidos por alguns acadêmicos da cidade, entre eles: César Franco, Alves de Faria, Affonso Guimarães, Luís Quirino, Américo de Campos Sobrinho e Pedro Moacyr. Ver Ana Luiza Martins, Revistas em revista: imprensa e práticas culturais em tempos de república, São Paulo (1890-1922), São Paulo: Editora da Universidade de São Paulo: Fapesp: Imprensa Oficial do Estado de São Paulo, 2001, p. 264.

${ }^{10}$ Ver Roberto Simões, op. cit., p. 58.
} 
pela demanda crescente do mercado, que recorria aos que dominavam a escrita, sobretudo em forma de versos, os quais eram mais facilmente memorizados.

Em dezembro de 1910, o próprio Olavo Bilac, talvez convencido pelo poeta Felipe de Oliveira, sobrinho do proprietário do laboratório farmacêutico Daudt \& Lagunilla, teria concedido sua imagem à propaganda do xarope Bromil, num reclame testemunhal ornamentado com motivos florais desenhados por Correia Dias. ${ }^{11} \mathrm{Na}$ realidade, tenha ou não sido convencido, o ganho em publicidade superava os valores pagos aos trabalhos da imprensa. Quando nos referimos à participação de Bilac na propaganda brasileira encontramos um material abundante, até mesmo o valor cobrado por suas rimas, que segundo Luiz Edmundo:

Diz-se que das folhas do tempo, exceção feita do "Correio da Manhã”, a “Gazeta” é a que paga melhor. Um seu repórter ganha de $160 \$$ a $200 \$$, um redator de $280 \$$ a $400 \$$, um secretário ou redator chefe de $500 \$$ a $700 \$ 00$.

O grande Bilac não ganha senão 50 \$ por crônica, porém, com a sua verve, tira três mais do que isso, por semana. A época é a da reclame em verso, mas do bom e espirituoso verso, como só ele sabe fazer. Paga-se por uma quadra, em geral, quando bem feita, 20 e 30 mil réis. Por algumas, porém chega Bilac a receber muito mais. Cem mil réis pagaram-lhe os industriais dos Phosphoros Brilhante, por esta:

Aviso a quem é fumante:

Tanto o príncipe de Galles, Como o dr. Campos Salles, Usam Phosphoros Brilhante.

e,

Certa vez, o fotógrafo Leterre pede-lhe uma quadra, mas, explica: para ser publicada com a própria assinatura do poeta. Bilac escreve a quadra, que outra não é senão esta:

Que em sagrado não se enterre

Quem não tiver, hoje em dia,

A sua photographia

Feita na Casa Leterre...

e manda, como conta, ao fotógrafo, isto:

${ }^{11}$ Daudt \& Lagunilla (posteriormente Daudt \& Oliveira) em suas campanhas para o xarope Bromil, também contou com versos redigidos, além de Olavo Bilac, por Basilio Viana, Bastos Tigre, Emilio de Menezes, Hermes Fontes e Álvaro Moreyra. Segundo Herman Lima, História da caricatura no Brasil, Rio de Janeiro: José Olympio Editora, v. 2, 1963, p. 708. Sobre o reclame testemunhal de Bilac, ver Nelson Varón Cadena, Brasil - 100 anos de propaganda, São Paulo: Edições Referência, 2001, p. 24. 
Por uma quadra reclame.

$.30 \$ 000$

Por uma assignatura do poeta

Olavo Bilac, na mesma quadra, a ser publicada

200:000\$000

200:030\$000

Leterre não aceita a fatura enviada. Manda cinqüenta mil réis e contentase com a quadra sem assinatura. ${ }^{12}$

Da comparação de valores e do prêmio pago pelo concurso do Chocolate Lacta mencionado por Sevcenko, pode-se concluir que redigir reclames era uma atividade para-literária vantajosa, bem mais rentável do que trabalhar para a imprensa como cronista, repórter ou redator. Tudo indica que esta prática no decorrer dos anos continuou a ter valores atraentes, visto que Guilherme de Almeida com seu slogan "La Fonte, a fechadura que fecha e dura”, "teria ganho 30 contos (!) por esse estalo de Vieira ... (Naquele tempo, um Chevrolet zero km custava 15 contos. Sem dúvida, foi um “free lance” regiamente pago!)”,13 ou ainda Manuel Bandeira que recebeu, segundo Nelson Varón Cadena, 50 mil réis pelo reclame das Pílulas Minorativas. ${ }^{14}$

A relação dos homens das letras com a publicidade era significativa, não só pelo caráter literário emprestado aos reclames, mas, também, pela atuação de um empreendimento como a Agência Americana da qual foram sócios Olavo Bilac e Martins Fontes. ${ }^{15}$ Relação ainda mais intensa, constante e criativa se verifica em Bastos

\footnotetext{
${ }^{12}$ Luiz Edmundo, O Rio de Janeiro do meu tempo, Rio de Janeiro: Imprensa Nacional, v. 3, 1938, pp. 944-946. Sobre o valor monetário da época consultar Marcelo Balaban, "Introdução”, in Bastos Tigre, Instantâneos do Rio antigo, Campinas: Mercado de Letras: Cecult; São Paulo: Fapesp, 2003, pp. 17-18. Balaban cita que um número avulso de revista era vendido por 200 ou 300 réis, um almoço completo para um grande grupo de pessoas saía por 10 mil réis e o preço de partituras variavam entre $1 \$ 000$ e $1 \$ 500$.

13 Caio A. Domingues, "Modelo brasileiro de propaganda", Propaganda, São Paulo, XVII (208): 37, nov. 1973.

${ }^{14}$ Nelson Varón Cadena, op. cit., p. 65. O anúncio comercial seria: Meu Deus que mulher durinha! // foi um buraco na minha vida // Mas eu mato ela na cabeça // vou mandar-lhe uma caixinha de Minorativas // Pastilhas Purgativas // impossível que não faça efeito!

${ }^{15}$ Raimundo de Menezes, Martins Fontes, São Paulo: Edições Melhoramentos, s.d., pp. 27-28. Segundo o autor, a Agência Americana era uma prestadora de "serviço de propaganda dos produtos do Brasil, com informações diárias sobre cotações dos mercados, principalmente com referência ao café". Em Paris, os poetas estabeleceram o escritório principal, mas também atuavam em Londres, Hamburgo, Havre e Nova York. Raimundo de Menezes também menciona que Martins Fontes teria retornado ao Brasil em 15 de agosto de 1918, e muito provavelmente a Agência Americana tenha finalizado suas atividades, sobretudo em função das dificuldades geradas pela Grande Guerra. Acrescenta-se, por fim, que Bilac teria sido sócio de uma agência de propaganda com escritório na avenida Rio Branco, por volta de 1908.
} 
Tigre que optou viver da publicidade, dispondo de um pequeno escritório, a Publicidade Bastos Tigre, ${ }^{16}$ em funcionamento a partir de 1913.

Dentre alguns nomes de escritores atuantes no Rio de Janeiro e em São Paulo pode-se mencionar a colaboração na publicidade brasileira dos da primeira geração: Casimiro de Abreu, Emílio de Menezes, Olavo Bilac, Hermes Fontes, Bastos Tigre, Guimarães Passos, Basílio Viana, Lopes Trovão, Felipe de Oliveira, Álvaro Moreyra; e, posteriormente, a significativa contribuição de Orígenes Lessa, ${ }^{17}$ Guilherme de Almeida, Menotti Del Picchia, Afonso Schmidt, Ribeiro Couto e Manuel Bandeira.

Além dos ganhos extras, existem motivações outras para a redação publicitária, aquelas que advêm das relações de amizade que fundamentam a sociabilidade e a identidade do grupo de literatos e que são determinantes para a eleição dos seus pares e a expansão dos contatos profissionais. Assim, verifica-se que a produção dos versos em rimas deu-se também por brincadeira em roda de amigos, a exemplo de Bilac e Leôncio Correia na bodega Taverna dos Bons Pães, ou então por amizade, como é o caso dos reclames para a Vela Brasileira de fabricação de Júlio Otoni, que foi assunto predileto de Bilac em vários de seus poemas e versos. ${ }^{18}$

Disponível no site www.jrwp.com.br/artigos/arquivo-artigos.asp?offset=120. José Roberto Whitaker Penteado, Ainda a mídia, Referência [Artigos- JRWP], 26 ago. 2004.

${ }^{16}$ Elias Thomé Saliba, Raízes do riso: a representação humorística na história brasileira: da Belle Époque aos primeiros tempos do rádio, São Paulo: Companhia das Letras, 2002, p. 85. O autor considera o ano de 1908 e não 1913. Entre os clientes de Bastos Tigre figuram: a Confeitaria Colombo, o magazine Notre Dame, a Drograria V. Silva, cigarros York, Bayer, Brahma e Daudt \& Oliveira. Para este último criou as "Bromilíadas", uma paródia à obra de Camões, semanalmente publicadas na última página da revista D. Quixote durante os anos de 1918-1922. Bastos Tigre foi considerado por Orígenes Lessa como "o mais brilhante e o único verdadeiramente profissional da primeira geração que escreveu propaganda no Brasil. Propaganda de fundo literário, mais de tipo gaulês que americano. Mais para lembrar que provar, mais para chamar a atenção que convencer. Uma propaganda irônica meio displicente, apelando mais para a inteligência que para o bolso do freguês. Para provocar um sorriso mais, que promover uma compra... Sem os imperativos ensinados pelos americanos: Compre! Exija! Tome! Beba! Fume! Coma! Era um luxo, permitido pela concorrência fraca e pela modesta produção". Apud Arnaldo Ferraz de Abreu, Bastos Tigre: eclética trajetória, Rio de Janeiro: Lado A Editores Associados, 1987, p. 79.

${ }^{17}$ O início da carreira de Orígenes Lessa na propaganda remonta aos anos de 1928, quando ingressou como tradutor no Departamento de Propaganda da General Motors, ali permanecendo até 1931. Em 1932, ingressa como redator na N. Y. Ayer \& Son, atividade que exerceu durante mais de 40 anos em várias agências de propaganda. Lessa, além de ser redator publicitário, também se dedicou à pesquisa e ao estudo da propaganda brasileira, a exemplo de seu artigo Retrato de uma cidade através dos anúncios de jornal, que traça uma fisionomia da cidade de São Paulo a partir do exame dos anúncios de jornais de 1868. Artigo publicado na Separata da revista Anhembi, São Paulo, X (28), mar. 1953.

${ }^{18}$ Consultar Eloy Pontes, A vida exuberante de Olavo Bilac, Rio de Janeiro: Livraria José Olympio Editora, 1944, p. 201. O autor relata vários casos curiosos em que o poeta Bilac se envolveu quando da produção de reclames. 
Como vimos até agora, a classe literária dialogou com as novas demandas do mercado. Portanto, longe de uma passividade e aceitação da perda de seus espaços produtivos, a participação de alguns de nossos escritores e poetas na propaganda não foi tão somente circunstancial, pois eles souberam se inserir nesse mercado nascente, sobretudo se considerarmos a inexistência de mão de obra qualificada. E, semelhante construção analítica pode ser aplicada aos artistas do lápis, como veremos no desenvolver do nosso estudo, destacando a Seção de Desenho da Livraria do Globo.

A citação do editorial da Revista do Globo também denota que os artistas do lápis estariam perdendo seus espaços de atuação nas revistas ilustradas, pois em lugar das vinhetas e das ilustrações que comumente acompanhavam os poemas, encontra-se, na primeira página, um anúncio comercial. ${ }^{19}$

Se poema e anúncio ocupando a primeira página ou mesmo páginas nobres podem ser indicativos de um amadorismo das revistas em suas práticas publicitárias, ${ }^{20}$ por ainda não definirem sistematicamente os espaços a serem ocupados pelos seus anunciantes, também são reveladores de mudanças de gostos e de interesses, basta recuperarmos a importância que os anúncios passam a ter na imprensa periódica. Em verdade, a publicidade torna-se uma âncora para atrair anunciantes, reduzindo a dependência dos assinantes, o que não só era sinônimo de aumento da tiragem e, por conseguinte redução de custos dos periódicos, como também de melhorias nas publicações tornando-as mais competitivas, fatores estes essenciais para a extensão de suas vidas úteis. $^{21}$

\footnotetext{
${ }^{19}$ Não foi somente nas revistas que ocorreu a parceria entre anúncios e literatura, como indica a capa que Arnaldo Barbosa criou para Cartazes, um livro publicado em 1928. Na sua introdução, o autor, Paulo Mendes de Almeida comenta: “[...] Anúncios na capa de um livro de versos! [...] Não é muito horrível, não. Versos publicados; o que são senão propaganda das emoções sentidas? Cartazes, cartazes...”. Apud Yone Soares de Lima, A ilustração na produção literária: São Paulo - década de vinte, São Paulo: Instituto de Estudos Brasileiros da Universidade de São Paulo, 1985, p. 153.

${ }^{20}$ Comumente, nas duas primeiras décadas do século XX, existia uma rígida divisão entre os espaços destinados aos reclames e às diversas matérias do periódico, o que estabelecia uma evidente distinção hierárquica. Lembramos que, ainda nos anos 1920, era possível encontrar algumas revistas que destinavam às propagandas as suas terceiras e quartas capas.

${ }^{21}$ Foi nos anos 30 do século XIX, que o francês Emile de Giradin propôs essa relação orgânica entre a imprensa e a publicidade (os anúncios pagam o periódico). Dessa conexão, a publicidade recebeu uma importante contribuição para o seu desenvolvimento. Para um aprofundamento do assunto, consultar José Ramón Sánchez Guzmán, Breve historia de la publicidad, 2ª ed, Madrid: Ediciones Forja, 1982, p. 40.
} 
Heloisa de Faria Cruz, em seu estudo sobre os periódicos paulistanos, menciona que na década de 1920 o reclame ocupava mais de 30\% dos conteúdos editados. ${ }^{22}$ Portanto, era fundamental renovar a linguagem publicitária em seu conjunto textoimagem. E, devido à inexistência no mercado de profissionais específicos, recorria-se aos artistas do lápis e aos poetas mais conhecidos, ou mesmo ainda, àqueles que já faziam parte do corpus editorial da revista e do jornal, que de certo modo avalizavam os produtos anunciados, principalmente quando dispunham da identificação da autoria, e, por conseguinte o próprio veículo. Exemplificando este último caso, encontramos referências, entre outras, de que Antonio Paim Vieira, ilustrador de Ariel (1923-1929) até seu número 12, foi o responsável também por algumas de suas matérias publicitárias, a exemplo dos anúncios xilogravados para a casa de Modas Elisa Giaccone Macelloni \& CA [FIGS. 34, 35, 36, 39, 1924] e para a CASA RAMOS ALFAIATARIA [FIG. 37, 1924] e muito provavelmente outros que não estão assinados, mas nos quais o traço de Paim é inconfundível, a exemplo do anúncio LYRA PAULISTANA [FIG. 30, 1924]. ${ }^{23}$

Os próprios diretores das revistas ilustradas encarregavam-se de vender assinaturas e conseguir anúncios. ${ }^{24}$ Este foi o caso de Cassiano Ricardo, diretor da revista Novíssima, que considera ter sido um

"período amargo" na vida, em que ele e Francisco Pati saíam para "cavar anúncios”, passando os maiores apuros, quase mendigando o auxílio dos

\footnotetext{
${ }^{22}$ Heloisa de Faria Cruz, São Paulo em papel e tinta: periodismo e vida urbana - 1890-1915, São Paulo: Educ: Fapesp: Arquivo do Estado de São Paulo: Imprensa Oficial do Estado de São Paulo, 2000, p.161.

${ }^{23}$ Consultar, respectivamente Ariel: Revista de Cultura Musical, São Paulo, (5): s.p., fev. 1924; (7): s.p., abr. 1924; e (4): s.p., jan. 1924.

${ }^{24}$ A título de curiosidade os preços dos anúncios e espaços publicitários variavam não só de revista para revista, mas também em função de sua localização na publicação, a exemplo de Bandeira Brazileira (1918): - capa externa $1^{\text {a }}$ vez $100 \$ 000$; capa externa outras: 70\$000; capa interna $1^{\text {a }}$ vez 80\$000; capa interna outras: 50\$000. Ilustração de São Paulo (1918-1924): - na capa externa: 1 página em 2 cores: $150 \$ 000$; 1/2 página em 2 cores 80\$000; capa interna: 1 página: $100 \$ 000 ; 1 \frac{1}{2}$ página $60 \$ 000$. O Parafuso Semanário Illustrado e Crítico (1915-1922): - capa (página externa): 250\$000; texto (1 página) 300\$000; capa (página interna): 200\$000, texto (1/2 página) $150 \$ 000$, texto (com quadrinhos) $20 \$ 000$ e texto (rodapé) $50 \$ 000$. Consultar Heloisa de Faria Cruz (org.), São Paulo em revista: catálogo de publicações da imprensa cultural e de variedades paulistana 1870-1930, São Paulo: Arquivo do Estado, 1997, pp. 66, 138 e 190. A Revista do Globo em 16 fev. 1929 apresentava a seguinte tabela de preços: 1 página 200\$000; $1 \frac{1}{2}$ página $120 \$ 000 ; 2^{\mathrm{a}}$ e $3^{\mathrm{a}}$ páginas da capa $300 \$ 000$ e $4^{\mathrm{a}}$ página da capa 400\$000; dados citados na dissertação de mestrado de Alice Dubina Trusz, A publicidade nas revistas ilustradas: o informativo cotidiano da modernidade. Porto Alegre - Anos 20, Porto Alegre: Instituto de Filosofia e Ciências Humanas da Universidade Federal do Rio Grande do Sul, 2002, p. 149.
} 
comerciantes. E lamenta, inclusive, os "expedientes inabituais e penosos” como classifica o trabalho de Francisco Pati que escrevia "versos-propaganda, por exigência dos anunciantes. Cita por exemplo o caso da pomada "Onken”, cujo anunciante exigia versos novos em cada anúncio. $^{25}$

Vender a revista. Empregar os traços dos artistas plásticos e gráficos para a execução de belas ilustrações para contos e capas com a finalidade de seduzir o leitor pela imagem, permitindo um prazeroso flanar pela revista, aponta que os anúncios deveriam seguir o mesmo caminho. E, em decorrência, a confecção das peças publicitárias, muito provavelmente, se enquadrava no perfil ideológico e estético da revista, o que para os anunciantes que investiam nas propagandas era sinônimo de segurança, pois de antemão já existia um público definido e afim aos produtos anunciados, porém, como veremos na seqüência, a revista Klaxon como porta-voz de seus patrocinadores foi uma exceção.

“Primeira página, os anúncios”. Retomando o editorial de Theodomiro Tostes, percebemos que as convivências sugeridas como modernas do poema com anúncios ou com o cartaz de um filme americano não só informam sobre as mudanças de distribuição das matérias nas páginas das revistas ilustradas que extrapolam as práticas tradicionais, mas, também, dão conta da necessidade de renovação estética das mesmas, visando, certamente, melhores vendas. E, é nesta direção, apesar de não ser a única como veremos oportunamente, que devemos entender a capa dupla (I e IV) [FIG. 130], do último fascículo do ano de 1935, da Revista do Globo executada por Nelson Boeira Faedrich. ${ }^{26}$ Trata-se de um colorido anúncio da CERVEJARIA CONTINENTAL, no qual somente a IV capa contém elementos gráficos que aludem aos produtos anunciados. Se, na época, era usual a IV capa ser destinada aos anúncios, esse exemplo passa a incluir a primeira página também, o que denota novas estratégias publicitárias. Um outro exemplo pode ser encontrado na capa que Paim Vieira concebeu para o primeiro número da revista, Novíssima (1923-1924), uma propaganda da própria revista.

No período em que a propaganda ainda estava em sua fase empírica e entregue, em parte, aos desenhistas do lápis das revistas ilustradas e dos jornais, era comum a associação dos caricaturistas aos poetas. Assim é que em 1918, o fabricante do xarope

\footnotetext{
${ }^{25}$ Maria Lúcia Fernandes Guelfi, Novíssima: estética e ideologia na década de vinte, São Paulo: Instituto de Estudos Brasileiros da Universidade de São Paulo, 1987, p. 23.

${ }^{26}$ Ver Revista do Globo, Porto Alegre, 7 (174): capas I e IV, 25 dez. 1935. Esse trabalho foi realizado inicialmente para um concurso e depois aproveitado como capa de final de ano.
} 
Bromil ainda se utilizava dos reclames testemunhais combinando, porém caricatura e versos, respectivamente de Romano e de Basílio Viana [FIG. 152, 1917]. Posteriormente, essa ação combinada entre sonetos rimados do produto com a caricatura ou desenho dará vez ao reclame desenhado pelo caricaturista sem as rimas, como se verifica pelo anúncio do GUARANÁ EsPUMANTE [FIG. 146] desenhado por Voltolino para divulgar nos primeiros anos da década de 1920 Narizinho, livro recém-lançado de Monteiro Lobato, ou os cigarros Castellões um dos patrocinadores do livro O SacyPererê (1918). Em outros momentos, vamos encontrar o caricaturista como redator de anúncios, a exemplo também de Voltolino, em seus anúncios para o chocolate Lacta e para o guaraná Espumante. ${ }^{27}$

Outros casos que ocorreram na história da nossa propaganda e que merecem ser citados, pelos intercâmbios entre o lápis e a pena envolvendo também os anúncios da Lacta, COMA LACTA [FIG. 26, 1922] e do GUARANÁ ESPUMANTE [FIG. 27, 1922] ${ }^{28}$, são de Guilherme de Almeida. ${ }^{29}$ Apesar dessas duas matérias publicitárias serem inovadoras para a época do reclame, seus anunciantes

não gostaram da inventiva Klaxiana. Não avaliaram os novos rumos que os anúncios abriam. Reagiram cortando a “conta”. Conseqüentemente, os agentes publicitários da revista, perderam a função.

A revista ficou irritada com essa atitude e, por isso, lançou o seu protesto na secção Luzes e Refrações - dedicada a comentários e breves notas sôbre o assunto. Protesto bem humorado, piadístico e brincalhão. ${ }^{30}$

Eis a resposta dos modernistas de Klaxon:

Os nossos leitores devem lembrar-se que lhes recomendámos como productos magnificos da nossa industria: o chocolate Lacta e a bebida Guaraná. Efectivamente tanto um como outra eram magnificos. Acontece porem que se tornaram detestáveis. Aconselhamos pois aos nossos

\footnotetext{
${ }^{27}$ Cf. Ana Maria de Moraes Belluzzo, Voltolino e as raízes do modernismo, São Paulo: Marco Zero, 1992, pp. 180-181. Os anúncios foram publicados, respectivamente em O Sacy, São Paulo, 8 jan. 1926 e Il Pasquino Coloniale, San Paolo, 9 apr. 1921.

${ }^{28}$ Reclames publicados, respectivamente, na revista Klaxon: Mensageiro de Arte Moderna, São Paulo, (1): IV capa, 15 maio 1922 e (2): IV capa, 15 jun. 1922. Eles também podem ser localizados na edição fac-símile Mário da Silva Brito (introd.), Klaxon: mensageiro de arte moderna, São Paulo: Livraria Martins Editora, 1972.

${ }^{29}$ Segundo Aracy Amaral e Mário da Silva Brito teria sido Guilherme de Almeida o autor dessas peças publicitárias. Apud idem, s.p. A afirmação do poeta "fui eu mesmo quem compôs, a tesoura e goma-arábica” foi localizada no jornal o Estado de S. Paulo, 10 fev. 1968.

${ }^{30}$ Consultar a introdução de Mário da Silva Brito, mais especificamente o item "Renovação da Arte Publicitária”, Idem, s.p.
} 
pacificos leitores o uso de outros productos magnificos da industria nacional. É possivel porem que o chocolate Lacta e a bebida Guaraná voltem outra vez à antiga excellencia que perderam. Nós, como únicos representantes do mais alto gôsto paulista, publicaremos então gostosamente annuncios novos desse refresco e desse chocolate. Mas enquanto a casa productora não nos der mais anuncios (ela que desperdiça gordos lucros em gritar sua fabrica pelas folhas diarias de muito menor circulação que nossa revista, como o Estado de S. Paulo e o Jornal do Commercio) é certo que Lacta como Guaraná são de pessimo sabor e fazem mal á saude. KLAXON que, em sua já longe e benéfica existencia, sempre corroborou para a milhoria da saude publica avisa os seus leitores: NÃO COMAM LACTA NEM BEBAM GUARANÁ, pois enquanto essas marcas não dos (sic.) derem anuncios. E publicaremos mesmo, prazeirosamente, qualquer comunicação de enfermidade de qualquer natureza, provocada por êsses ingratos ingredientes. ${ }^{31}$

Nas contracapas de Klaxon, encontram-se os anúncios do gênero redacional, PAnuosopho, PAteromnium \& CiA. e Aviso Á PraÇA, ${ }^{32}$ que não deixam de ser uma crítica bem humorada ao uso que a propaganda faz dos versos ou então, como já mencionado por Sevcenko, "uma mercantilização da própria literatura"; neles se oferecem serviços para fabricar sonetos, madrigais, baladas e quadrinhas, e a sua apresentação incorpora a forma dos reclames da época.

Afora trabalhos na propaganda pode-se notar que as composições entre o lápis e a pena, sobretudo para os que iniciavam em suas carreiras, eram bastante comuns, como mostra o caso de Erico Verissimo, ${ }^{33}$ que nos anos 30 ilustrava contos e criava vinhetas para a Revista do Globo, chegando a elaborar uma capa para o seu número 51 de 24 janeiro de 1931. Um depoimento do escritor gaúcho ao considerar seu início de carreira nos dá conta de suas diversas atividades e dos entrelaçamentos de seus metiês:

Durante o dia eu trabalhava intensamente na redação da Revista do Globo. O processo era mais ou menos o mesmo de outras revistas brasileiras da época. Nossos colaboradores eram a tesoura e o pote de cola. Como nunca havia verba para comprar matéria inédita, o remédio era recorrer à pirataria. Eu traduzia os contos e artigos de revistas americanas, francesas, inglesas, italianas e argentinas, mandando também reproduzir em preto e branco suas ilustrações.

\footnotetext{
${ }^{31}$ Ver edição fac-símile de Klaxon: mensageiro de arte moderna, São Paulo, (4): 17, 15 ago. 1922.

${ }^{32}$ Idem, respectivamente, (7): contracapa, 30 nov. 1922 e (8-9): contracapa, dez. 1922 - jan. 1923.

${ }^{33}$ Em abril de 1931, Erico Verissimo inicia seu trabalho na Revista do Globo, como secretário, e posteriormente torna-se seu diretor. Não temos conhecimento que o escritor tenha realizado trabalhos publicitários para a revista gaúcha, somente capas, vinhetas e ilustrações.
} 


\section{[...]}

Tudo na redação tinha de ser feito às pressas. Às vezes, folheando revistas americanas, eu descobria nelas ilustrações que me agradavam. Mandava então transforma-las em clichês. Prontos estes, invertendo o processo habitual, eu improvisava um conto que se adaptasse às estampas e firmava-os com um nome suposto. ${ }^{34}$

Salientamos que essas parcerias se mantiveram durante muitos anos, mas se atenuaram em função da própria evolução da publicidade e de suas adaptações às exigências do mercado, da formação dos diversos profissionais que a enfeixam, bem como do emprego das novas mídias.

Certo é que alguns escritores abraçaram a publicidade como atividade regular, mas existem aqueles que ocasionalmente dela se utilizaram para ganhos extras, como é o caso de Emílio de Menezes. Essas incursões podem ser indicativas de certa resistência em ceder seus talentos à propaganda, uma atividade considerada marginal, ${ }^{35}$ e que proporcionava incomodas agulhadas aos seus participantes, a exemplo da crônica Anúncios... anúncios... de Lima Barreto que na fala de seus personagens, comenta:

-Que diabo tu lês aí, que não me dás nenhuma atenção?

-Anúncios, meu caro; anúncios...

-É o recurso dos humoristas à cata de assuntos, ler anúncios.

-Não sou humorista e, se leio os anúncios, é para estudar a vida e a sociedade. Os anúncios são uma manifestação delas [.... ${ }^{36}$

Posicionamentos como estes nos induzem a refletir sobre a auto-imagem e o status de intelectuais desses profissionais das letras.

Bilac, ao testemunhar sobre a atuação do escritor no jornalismo, reconheceria ser este campo um "grande bem" e "o único meio do escritor se fazer ler" e, portanto de se fazer conhecer. Porém,

se um moço escritor viesse, nesse dia triste, pedir um conselho à minha tristeza e ao meu desconsolado outono, eu lhe diria apenas: Ama tua arte

\footnotetext{
${ }^{34}$ Carla Fernanda Fontana, O ateliê de desenho da Livraria do Globo, São Paulo: Escola de Comunicações e Artes da Universidade de São Paulo, 2004, p. 24. TCC - Departamento de Jornalismo e Editoração.

${ }^{35}$ Devemos considerar que além das atividades literárias, muitos escritores e poetas estavam vinculados ao funcionalismo público ou exerciam outras ocupações.

${ }^{36}$ A crônica Anúncios... Anúncios..., s.d., está disponível no site www.dominiopublico.org.br.
} 
sobre todas as coisas e tem coragem, que eu não tive, de morrer de fome para não prostituir o teu talento! ${ }^{37}$

Marcelo Balaban comenta que Bastos Tigre encontrou dificuldades em ser aceito pelos seus pares, quando, em 1936, foi recusado como membro da Academia Brasileira de Letras, muito provavelmente por ter sido considerado por Luiz Edmundo "um mercantilista das letras". ${ }^{38}$

As exigências formais feitas pelo concurso da Lacta, apresentadas anteriormente, nos auxiliam a entender as estratégias que os poetas adotavam em seus versos rimados para atender e satisfazer a demanda do mercado publicitário nascente. Eles não se desprendiam da norma culta e operavam obedecendo a seus estilos, tal qual Bastos Tigre vai dispensar em suas já mencionadas Bromilíadas [FIG. 13, s.d.].

Acreditamos que a relação dos homens das letras com a propaganda é mesmo ambígua, no momento em que a imprensa procurava se afirmar como um negócio rentável. Neste período de mudanças e transições, esses profissionais tentavam se colocar em espaços por vezes distintos, o do livro de circulação mais lenta que privilegia a elite culta, e o das revistas ilustradas, que se dirige a um público burguês, por sua vez mais amplo, diversificado e interessado na cultura do entretenimento que se edificava.

Portanto, ao lado dos profissionais da pena, encontramos os desenhistas, ilustradores, caricaturistas, pintores, litógrafos e fotógrafos, todos indispensáveis nas revistas ilustradas do período analisado. Em relação a esses profissionais, Ana Luiza Martins considera

tal sua importância nesse periodismo técnico-industrial, que acabou por ascender no expediente da revista, com seu nome estampado no cabeçalho, ao lado do proprietário, do gerente, do redator-chefe, por vezes acima dos habituais redatores, no qual comparecia sob a denominação de “diretor artístico". Inserção que se caracterizou pela mesma resistência em aderir ao periodismo, percebida ao homem de letras ao experimentar o jornal. O artista do pincel e da tela, algumas vezes laureado pensionista do Estado, com passagem pela Academia Julien de Paris, não se enxergava no campo pragmático das oficinas de impressão gráfica. As exigências de mercado, contudo, o encaminharam para aquelas instalações. Em princípio com ressalvas, apenas um

\footnotetext{
${ }^{37}$ Ver Bastos Tigre, op. cit., pp. 44-45.

${ }^{38}$ Idem, p. 24. Segundo Elias Thomé Saliba, op. cit., p. 183, os poetas humoristas do Rio de Janeiro foram muito solicitados para produzir reclames e anúncios publicitários em geral, se comparados aos paulistas.
} 
complemento de sua atividade regular, mas acabando por profissionalizar-se, através da colaboração imprescindível e de grande visibilidade na imprensa da época. Como para o homem de letras, também para o artista plástico, o periodismo resultou no espaço possível de colocação fosse para o reconhecimento público ou pela remuneração complementar. ${ }^{39}$

Ao longo do texto procuramos delinear as transformações ocorridas no status quo da classe dominante da "cultura letrada" e ao mesmo tempo testemunhamos a agregação de novos atores e grupos sociais que tomam para si a responsabilidade de abrir não só novos espaços de atuação na imprensa, mas também de gerir novas demandas culturais, descoladas do oficialismo tradicional que se ampara fortemente na importação cultural. Essas frentes configuram um mercado de trabalho com novas possibilidades seja para os artistas do lápis quanto para os da pena. Portanto, o reconhecimento e a filiação desses profissionais às novas formulações que se apresentam, mesmo sendo consideradas de menor valor, são aceitos com mais desprendimento.

Neste momento de nosso estudo e considerando a observação supracitada, nos dedicamos a analisar a Revista do Globo por acreditamos que ela concilia procedimentos operacionais de época que podem se estender as outras revistas e nos auxilia no exame do mercado de trabalho dos artistas plásticos. Evidente, que a revista gaúcha tem contornos que lhe são próprios, sobretudo, pela distância cultural que a separa do eixo artístico e cultural Rio-São Paulo, mas revela práticas comuns da imprensa. Assim sendo, tal publicação deve ser considerada não só como integrante da história das nossas revistas ilustradas, mas, também, como veremos, da história da propaganda e das artes plásticas do Rio Grande do Sul.

\footnotetext{
${ }^{39}$ Ana Luiza Martins, op. cit., p. 252. Exemplificando, segue-se uma pequena lista do nome de alguns diretores artísticos paulistas: J. Prado: A Garoa (1921-1922); Mick Carnicelli: Papel e Tinta (1920-1921); Alfredo Norfini: Illustração Paulista (1910-1912); Di Cavalcanti: Panoplia (1917-1919); Antonio Paim Vieira: Pallas (1920-1921) e Belmonte: Juca Pato (1927) figurando como diretor honorário, e Sótero Cósme na revista gaúcha Madrugada (set.dez. 1926). Ver Heloisa de Faria Cruz (org.), São Paulo em revista: catálogo de publicações da imprensa cultural e de variedades paulistana 1870-1930, op. cit., pp. 128, 140, 185, 153 e 186-187 e Carlos Scarinci, A gravura no Rio Grande do Sul 1900-1980, Porto Alegre: Mercado Aberto, 1982, p. 37.
} 
Nos últimos anos a Revista do Globo $^{40}$ vem sendo submetida a interessantes e diversos estudos, dos quais destacamos os de Paula Viviane Ramos e Carla Fernanda Fontana. Apesar do primeiro se ater à análise da produção das capas (1929-1939) do periódico gaúcho e o segundo tratar das obras dos artistas gráficos publicadas nos títulos ilustrados da Seção Editora entre o início dos anos 30 e o final dos anos 40, ambos informam sobre a Seção de Desenho da Livraria do Globo (1929), que nos interessa mais de perto. Acrescenta-se a eles o livro de Maria Helena Steffens de Castro que aborda a publicidade textual veiculada na revista nos anos compreendidos entre 1929 e 1949. ${ }^{41}$

Segundo Sonia Maria de Amorin, a Seção de Desenho talvez tenha sido a única na época nas editoras brasileiras ${ }^{42}$ e ela foi constituída para suprir as necessidades da área iconográfica da Livraria do Globo em seu todo, bem como a prestação de serviços para terceiros. A Seção de Desenho é estimada como um dos fatores responsáveis pela formação de uma nova mentalidade e de um meio artístico mais "atualizado", sobrepujando muitas vezes o ensino e as práticas culturais mais conservadoras da cidade de Porto Alegre, ainda que não exercesse uma declarada oposição ao Instituto de Belas Artes (1908).

Sob a orientação profissional de Carl Ernst Zeuner, ${ }^{43}$ a Seção de Desenho desde seu início amealhou para si dois perfis de artistas, os artistas plásticos já conhecidos na década de 30, tais como João Fahrion, Edgar Koetz, Nelson Boeira Faedrich, João Faria

\footnotetext{
${ }^{40}$ Editada pela Livraria do Globo, a Revista do Globo, entre os anos de 1929 e 1967, foi tida como a principal revista que circulou no sul do país. Segundo Paula Viviane Ramos, ganhou projeção nacional tornando-se a segunda em circulação, depois de O Cruzeiro. Consultar a dissertação de mestrado de Paula Viviane Ramos, A experiência da modernidade na Seç̧ão de Desenho da Editora Globo. Revista do Globo (1929-1939), Porto Alegre: Instituto de Artes da Universidade Federal do Rio Grande do Sul, 2002, p. 18.

${ }^{41}$ Respectivamente, Idem, ibidem ; Carla Fernanda Fontana, op. cit. e Maria Helena Steffens de Castro, O literário como sedução: a publicidade na Revista do Globo, Porto Alegre: EDIPUCRS, 2004.

${ }^{42}$ Consultar Sônia Maria de Amorim, Em busca de um tempo perdido: edição de literatura traduzida pela Editora Globo (1930-1950), São Paulo: Editora da Universidade de São Paulo: Com-Arte; Porto Alegre: Editora da Universidade - UFRGS, 1999, p. 50. Para um aprofundamento sobre a Seção de Desenho da Livraria e Editora do Globo, remetemos, sobretudo, aos títulos anteriormente citados. Não será o nosso objetivo nos atermos em detalhes da sua história, mas dela pinçaremos fatos e dados que sejam relevantes ao estudo.

${ }^{43}$ Ernst Zeuner, artista gráfico alemão, foi contratado pela Livraria do Globo em outubro de 1922.
} 
Vianna e Sotéro Cósme, e aqueles jovens aprendizes que no decorrer dos anos vieram a ser reconhecidos como artistas plásticos ou mesmo como profissionais publicitários, dentre esses últimos citamos, Vitório Gheno, João Mottini e Armando Arnildo Kuwer. ${ }^{44}$

A Seção de Desenho da Globo foi uma oportunidade profissional não só para os jovens aprendizes das artes gráficas, mas também para os das artes plásticas, a exemplo de João Mottini, que aos quinze anos (1938) começou a trabalhar com Zeuner e Fahrion como alternativa à sua impossibilidade financeira de estudar na Escola de Belas-Artes local. $^{45}$

Foi fundamental para o aprendizado do grupo de profissionais da Seção de Desenho o contato que tiveram com algumas publicações internacionais das artes gráficas, algumas assinadas pela própria Globo, como a francesa Les arts et les techniques graphiques e a alemã Gebrauchsgraphik. Em relação a esta, Zeuner incentivava sua equipe a se exercitar na cópia do desenho de figuras e de letras. Também circulava Publisher's Weelky, revista americana que informava sobre os novos títulos a serem lançados no mercado. ${ }^{46}$

Como mencionamos anteriormente era prática habitual das revistas disporem de um elenco próprio de artistas do lápis, como prestadores de serviços ou funcionários da casa. O mesmo teria ocorrido na Seção de Desenho, mas ela, ao nosso entender, expandiu-se para fora desses confins, muito provavelmente pela escassez de profissionais qualificados, e acabou tomando para si não só a responsabilidade de ensinar e qualificar jovens para o trabalho gráfico, como também os artistas plásticos gaúchos já consagrados, mas, do mesmo modo criar novos espaços de aprendizado

\footnotetext{
${ }^{44}$ Nelson Boeira Faedrich menciona que "a equipe estável do ateliê era composta por Ernest Zeuner, João Fahrion, Edgar Koetz e eu, Nelson Boeira Faedrich. Além de nós, vários desenhistas trabalharam em diversos períodos: Gastão Hofstetter, Vitório Gheno, Honório Nardin, João Mottini, Edla Silva, Kraemer, Edgar Klettner, João Faria Viana e mais alguns nomes, de passageira estada”. Faedrich também específica algumas atribuições desses artistas, mas não se refere a anúncios comerciais, somente a produção de cartazes, os quais ficariam a cargo dele e de Edgar Koetz. Apud Carla Fernanda Fontana, op. cit., p. 70.

${ }^{45}$ Idem, p. 64. Para Mottini a convivência com Fahrion na Seção de Desenho pode ser entendida como uma extensão ao seu desejo de estudar na Escola de Belas Artes, visto que Fahrion já ministrava aulas de desenho e pintura nessa instituição de ensino. E, ainda foi na própria Livraria da Globo que Mottini, Vitório Gheno e Honório Nardin receberam as primeiras noções de aquarela com João Faria Vianna.

${ }^{46}$ Idem, pp. 65-66. Na época outras revistas estrangeiras circulavam em Porto Alegre, pois Nelson Boeira Faedrich menciona que também teve contato desde jovem, através de seu tio, com as revistas européias The Studio (inglesa) e L'Illustration (francesa) que o ajudaram a se interessar pelo desenho e pelas artes gráficas. Idem, p. 168.
} 
lançando no mercado profissionais da área, como a Escola de Artes Gráficas ${ }^{47}$ (19441957) que nesse período conviveu no mesmo espaço físico da gráfica da Globo. Portanto, a Seção de Desenho é tida como um núcleo fomentador da formação de artistas gráficos e plásticos, e derivando dessa atuação uma contribuição das mais significativas para o circuito artístico gaúcho, “uma precursora da modernidade artística do Rio Grande do Sul” como salienta Paula Viviane Ramos ao se referir a determinadas capas do quinzenário, especificamente por apresentarem, a partir da década de 1930, "uma visualidade mais arrojada” e um tratamento gráfico diferenciado, um "protodesign gráfico" que se aproxima da linguagem do cartaz. ${ }^{48}$

Decorrente dessa formação diversificada, que mescla concomitantemente aprendizagem e trabalho, é a capacitação desses profissionais para atuar no ensino das artes e também nas agências de propaganda, ${ }^{49}$ que, a partir da década de 40 , surgiram em Porto Alegre, pagando salários bem mais atraentes aos desenhistas que aos poucos foram deixando a Livraria do Globo.

Um outro viés que merece nossa atenção é o tratamento que a Revista do Globo dispensava em suas páginas às artes plásticas e mais especificamente aos seus profissionais. Publicavam-se matérias sobre as exposições de artes e os concursos de artes gráficas (cartazes, selos e outros), que contavam com a participação de seus funcionários. Procedimento que se estendia aos lançamentos dos livros da Editora Globo que obviamente procurava destacar o trabalho artístico de seus ilustradores. Prática não ingênua. Em verdade, uma dupla via que se complementa, pois se de um lado havia a valorização e a divulgação dos artistas da Livraria do Globo, por outro lado, a revista e a editora também se prestigiavam e se autopromoviam como um centro aglutinador e irradiador de talentos, por suas páginas poderem contar com trabalhos de artistas consagrados pela crítica de arte, muitos dos quais aprendizes que iniciaram suas carreiras na Seção de Desenho.

Seguindo nesta direção, a revista igualmente age como mediadora, seja criando demanda ao consumo dos livros da própria Editora Globo, como também de obras de arte, por injetar no mercado modelos artísticos ao se assumir, seja como um espaço expositivo, pois muitas vezes as capas da Revista do Globo eram reproduções das telas

\footnotetext{
47 Também denominada de Escola de Tipografia. Ela foi mantida em parceria com o Senai Serviço Nacional de Aprendizagem Industrial e dirigida por Frederico Porta.

${ }^{48}$ Paula Viviane Ramos, op. cit., p. 250.

${ }^{49}$ Armando A. Kuwer, João Mottini, Honório Nardin, Julio Costa, Dorival de Azevedo e Rui Nogueira, são alguns nomes de artistas gráficos que se dedicaram aos trabalhos publicitários.
} 
de seus artistas-funcionários, a exemplo de Fahrion, seja como um espaço crítico de divulgação do próprio artista da casa. ${ }^{50}$

Levando-se em conta o modesto ambiente artístico gaúcho, torna-se presumível que o sucesso para os artistas estivesse ligado aos mesmos preceitos de sucesso do sistema acadêmico vigente, ou seja, ao reconhecimento, às encomendas, às oportunidades de trabalho e consequentemente ao ganho financeiro. Portanto, a revista ilustrada, uma instituição não oficial, acaba fazendo parte do sistema das artes, tomando emprestado o lugar do profissional de mediação junto a um público mais amplo, legitimando o talento do artista, proporcionando-lhe abertura de mercado e remuneração.

Nesse circuito que se auto-alimenta, é interessante notar as novas alternativas de trabalho e atuação no meio artístico de Porto Alegre que surgiam para esses profissionais, a exemplo

- da coluna social desenhada de João Fahrion (1937) nas páginas da Revista do Globo que lhe possibilitou trabalhos como retratista junto à elite portoalegrense. E, neste mesmo ano o artista passa a ensinar pintura no Instituto de Artes de Porto Alegre;

- da formação no final dos anos 30 da Associação de Artes Plásticas Francisco Lisboa pelos desenhistas da Livraria, entre eles: João Faria Viana, Edgar Koetz, Gastão Hofstetter e Edla Silva, sendo que a própria empresa patrocinava as exposições do grupo.

Desse encaminhamento, concluímos que a Revista do Globo incentivou a vida artística de Porto Alegre, possibilitando trabalho aos artistas locais, mobilizando o meio artístico ainda incipiente, carente de um circuito artístico, como salões de arte, galerias e museus.

A esse núcleo de profissionais da Seção de Desenho atribui-se não só as ilustrações de livros da Seção Editora, capas e contos, e as caricaturas (em número reduzido, diferenciando-se assim das revistas e dos jornais paulistas e cariocas) da Revista do Globo, mas também seus anúncios comerciais.

\footnotetext{
${ }^{50}$ Fahrion e Francis Pelicheck tiveram seus auto-retratos publicados na Revista do Globo, respectivamente na capa da edição número 5 de 1931 e em página inteira no número 4 da revista do ano de 1930. Complementando esse quadro, profissionais da Globo e colaboradores eventuais da revista, a exemplo do escultor Fernando Corona, também eram agraciados com reportagens.
} 
Desde o seu início a Seção de Desenho assumiu a produção de anúncios publicitários, herança ou continuidade dos ateliês tipográficos e litográficos das oficinas da Globo que imprimiam apólices de seguros, papéis bancários, bilhetes de loteria, rótulos, diplomas, cartazes, entre outras peças. Diante da experiência desse grupo de desenhistas e ilustradores acrescido da equipe de redação da revista, constitui-se a Clarim Empresa de Publicidade Ltda. (1947- 1960), que de uma agência da casa, house agency, expandiu-se de modo a prestar serviços ao empresariado gaúcho.

A Clarim é considerada a primeira agência de propaganda do Rio Grande do Sul. Observamos que ela foi engendrada ao longo dos anos dentro da própria Livraria do Globo, vivenciando a passagem da propaganda amadora e empírica para aquela racional e, portanto, mais próxima da técnica norte-americana, sobretudo a partir do momento em que a Revista do Globo passou a ter entre seus clientes empresas multinacionais. Segundo Maria Helena Steffens de Castro, nessa

agência formou-se um departamento de arte integrado pelo melhor grupo de artistas do país, formulando uma linha de serviços que compreendia o logotipo, a embalagem, o desenho industrial, o rótulo, o cartaz, a vitrina e o anúncio. O trabalho de artistas como Edgar Koetz, Vitório Gheno, os irmãos Haas, Nelson Boeira Faedrich e outros definiu a Clarim como formadora de talentos e uma das melhores em criatividade publicitária. ${ }^{51}$

Do mesmo modo que os poetas que produziram peças publicitárias devido à inexistência de profissionais específicos no período amador da nossa propaganda, situação esta muitas vezes associada a uma necessidade de complementar a renda, o mesmo ocorreu na Livraria do Globo, mais especificamente com o grupo da Seção de Desenho. Em termos de mercado de trabalho, deve-se considerar que na falta de profissional especializado na produção de peças comerciais, assumia aquele que soubesse ilustrar, desenhar letras ou mesmo redigir um texto publicitário.

Vitório Gheno justifica as suas atividades multidisciplinares (trabalhos ligados à moda, decoração de ambientes, artes gráficas e ilustrações de peças publicitárias) que bem pode ser aplicada a outros profissionais, como decorrentes não só do amadorismo de muitas profissões, mas também porque “a Escola de Arquitetura fazia parte da Escola

\footnotetext{
${ }^{51}$ Maria Helena Steffens de Castro, op. cit., p. 31.
} 
de Belas Artes e o aluno formava-se arquiteto, mas com vocação de artista, realizando obras em diferentes áreas”. 52

Não obstante a Revista do Globo dispor para a realização das suas ilustrações e anúncios comerciais da mesma equipe de ilustradores, desenhistas publicitários, litógrafos e caligrafistas, não se tem um estudo iconográfico comparativo entre essas produções. Mas, de antemão, é possível identificar a existência de limites mais rígidos quanto se trata da criação de matéria publicitária, muito provavelmente como meio de preservar a legibilidade e informação do produto anunciado, o que vem a ser somado às exigências dos anunciantes, a exemplo dos anúncios a bico-de-pena que Julio Costa criou para os produtos da Casa Masson e que foram "reproduzidos com tanta fidelidade” [FIG. 131, 1945]. ${ }^{53}$

Alguns desenhistas da Globo escolheram dar continuidade em suas carreiras orientando-se ao desenho publicitário, destacando-se nas agências publicitárias de Porto Alegre e realizando trabalhos em outras cidades brasileiras e até mesmo em outros países.

Acompanhando a produção de anúncios publicados na Revista do Globo, constata-se que um grande número deles não eram assinados, portanto desconhecemos seus autores, outros foram produzidos por diversas agências de propaganda localizadas em outras cidades brasileiras, e outros pela própria Clarim. Em particular, sabe-se que é possível encontrar alguns anúncios assinados e referências aos trabalhos de clientes, como:

Ernst Zeuner, que realizou trabalhos para Fogões Geral, Varig, Elixir Biiodado Santo Expedito; Nelson Boeira Faedrich, ilustrou anúncios da Casa Victor, Varejo Bromberg, Cerveja Continental, Refrigerador Kelvinator; Pelichek assinou peças da Livraria do Globo; Gastão Hofstetter, desenhou para a Casa Victor, a Formamint e a Wallau entre outros clientes; Vitório Gheno fazia as ilustrações e "montava” os textos dos anúncios das Lojas Renner, desenhando figuras femininas e artigos de vestuário, muito valorizados pela empresa. ${ }^{54}$

Acrescenta-se à lista acima o nome de Júlio Costa, considerado um dos primeiros publicitários do Rio Grande do Sul e que também trabalhou na Livraria do Globo, criando anúncios comerciais para a Casa Masson, medicamento Saphrol, Banco

\footnotetext{
${ }^{52}$ Apud idem, p. 20.

${ }^{53}$ Idem, ibidem.

${ }^{54}$ Idem, p. 32.
} 
Agrícola Mercantil, Loteria do Estado, Chocolates Neugebauer, Drogaria Kelin, Alfaiataria Alfano, entre outros. ${ }^{55}$

No que se refere às revistas ilustradas parece existir certa hierarquia entre os produtos das artes gráficas: destacavam-se as capas, seguidas das ilustrações para contos e livros, sendo os anúncios publicitários praticamente desconsiderados. Ao nosso entender, a omissão dos créditos e das autorias nas propagandas esbarra na dificuldade que o artista gráfico tinha em aceitar esta produção, considerada uma arte menor, como esclarece a citação que se segue:

os homens que faziam publicidade passaram de corretores de classificados em jornais, para redatores do anúncio, preparando o texto, ilustrando-o e distribuindo-o dentro do espaço da página. Não possuíam grandes conhecimentos técnicos, pois a publicidade ainda era feita por escritores e jornalistas, cujos textos eram ilustrados por artistas plásticos, que recortavam figuras de outras revistas, colavam e retocavam a ilustração até a arte final. Realizavam muitas vezes esse trabalho em casa, para preservar a "aura” de artistas plásticos, evitando identificaremse com criadores de anúncios. ${ }^{56}$

Não existem regras, mas de modo geral se percebe que os artistas que decididamente viviam da produção de anúncios comerciais e que tinham ateliês prestadores deste tipo de serviço ${ }^{57}$ assinavam seus trabalhos, mesmo porque este era 0 melhor meio de se fazerem conhecidos como profissionais da área. Já no caso da Revista do Globo, os artistas eram funcionários da casa, portanto assalariados, sendo que a Livraria do Globo acabava intermediando esse processo, incorporando ou não aos seus anúncios publicitários a assinatura do desenhista, ou então, o nome da sua agência, a Clarim.

Nos depoimentos dos artistas da Seção de Desenho e de seus familiares é possível verificar que a relação entre trabalhar para uma empresa, que implica em um trabalho comprometido com a encomenda, com a eficiência e os prazos, e desenvolver trabalhos artísticos pessoais, era conflituosa, tal qual para os poetas. O artista gaúcho

\footnotetext{
${ }^{55}$ Idem, p. 31.

${ }^{56}$ Idem, pp. 26-27.

${ }^{57}$ Citamos como exemplos o Ateliê Seth de Álvaro Marins e de J. Carlos, ambos no Rio de Janeiro. Na década de 30 verifica-se que os artistas plásticos abriam seus próprios ateliês de desenho de publicidade, trabalhando de modo independente.
} 
Edgar Koetz comenta que "raramente podia trabalhar para mim, pois precisava ganhar a vida”. 58

Algumas apreciações sobre o pintor Danilo Di Prete, atuante em São Paulo a partir dos anos finais da década de 40, também expõem o dilema que acompanhava o artista quando a necessidade financeira o obrigava a deixar de lado suas produções artísticas:

Seu objetivo aqui [no Brasil] era a pintura. Mas precisou de dinheiro para viver e o caminho foi o cartaz, em cuja técnica se fez com facilidade, obtendo vários prêmios. Cobra 3.000 cruzeiros por cada trabalho e seu principal cliente é a Standard Propaganda. Está bastante contente com suas experiências em propaganda, mas seu grande desejo é continuar pintando. Ele mesmo afirma: "Quero fazer dois cartazes por mês e pintar para mim". ${ }^{59}$

Essa colidente relação, que conduz à discussão entre as hierarquias das artes e a dignidade do artista, pode, no caso da Revista do Globo, melhor ser sentida no depoimento do sobrinho de Fahrion:

Por outro lado, se queixava [João Fahrion] com freqüência da falta de cuidado que o pessoal em geral tinha com os desenhos produzidos. Muitas vezes ele encontrava pedras litográficas com desenhos seus servindo de soleira em portas. Em outras situações, ele contava que as pedras litográficas eram colocadas no chão das oficinas gráficas, para diminuir a umidade. ${ }^{60}$

O depoimento de Carlos Raul Fahrion nos informa ainda que os artistas gráficos/plásticos, a exemplo de seu tio Fahrion, eram vistos como artesãos que trabalhavam a pedra litográfica para a produção de clichês. Importância maior era conferida aos escritores, talvez devido à revista ser um subsídio para os produtos da Editora Globo. ${ }^{61}$

A falta de cuidado e o desprezo pelas pedras litográficas de que Fahrion reclama, devem ser entendidas como o desabafo de um artista que se utilizava da técnica da litogravura para criar suas obras. Portanto era natural que ele, considerando o aspecto

\footnotetext{
${ }^{58}$ Carla Fernanda Fontana, op. cit., p. 140.

59 “Biografia Danilo Di Prete”, s.l., s.d., p. 22. Recorte de revista localizado na Divisão de Pesquisa do Arquivo Multimeios da SMC-PMSP do Centro Cultural São Paulo.

${ }^{60}$ Consultar o volume Anexos da dissertação de mestrado de Paula Viviane Ramos, op. cit., p. 25.

${ }^{61}$ Idem, ibidem.
} 
criativo e não o meramente técnico valorizasse seus trabalhos, fossem eles futuros clichês ou não, como também valorizasse os suportes e os materiais artísticos empregados.

Um outro depoimento, desta vez de Joaquim da Fonseca, expõe claramente os motivos preconceituosos que transitavam ao redor do artista gráfico:

Assim, eu fazia aulas no Instituto pela manhã e, à tarde, ia para a redação. Depois, fui trabalhar na MPM, agência de propaganda. Nesta época eu senti bem o que era o preconceito contra o artista gráfico. A pessoa do Instituto que se dedicava às artes gráficas era vista como um "prostituto". Eu mesmo fui visto assim. Afinal, eu trabalhava para o mercado, eu ganhava um dinheirinho pelas minhas imagens, eu produzia imagens de cunho comercial. Então, havia muito preconceito, e também muita inveja, porque o ilustrador ganhava um salário bem razoável, enquanto os meus colegas não tinham trabalho fixo remunerado. Mas, esse preconceito, infelizmente, existe até hoje.

Dentro do Instituto havia também um preconceito em relação ao Fahrion. Ele era visto como um cara que havia se vendido. Todos tinham um certo respeito por ele, mas os professores mais acadêmicos, digamos assim, o tratavam com indiferença e meio que incitavam isso nos alunos, porque ele era um cara que tinha produzido ilustrações para vender revistas e livros. E isso, lá dentro, não era visto com bons olhos. Assim o Locatelli era olhado com vistas grossas. Então, existia isso lá dentro. Mas esse tipo de preconceito não existe só aqui: em São Paulo é assim, em Nova Iorque é assim. Quando eu fui morar nos Estados Unidos eu percebi bem essa relação: lá, os profissionais são muito corporativistas e preconceituosos. Então, eu digo que isso é uma coisa do próprio sistema. Não sei se algum dia vai mudar. ${ }^{62}$

Se o ilustrador era tido como um artista menor, mesmo convivendo no mesmo espaço que o escritor, o qual de certo modo dignifica e legitima aquele que ilustra, elevando o seu status, podemos imaginar a desvantagem que o artista do lápis levava ao realizar anúncios comerciais soltos nas páginas das revistas ilustradas e que, de modo geral, subjugavam o aspecto criativo ao técnico, apresentando-se como uma linguagem mais distante ainda das belas artes. Por outro lado, não estavam nítidos os vínculos e a integridade do exercício das atividades gráficas entre a publicidade e o universo editorial, ${ }^{63}$ sem contar que:

\footnotetext{
${ }^{62}$ Idem, pp. 35-36.

${ }^{63}$ Esses vínculos só seriam mais claramente reconhecidos quando da conformação do design gráfico.
} 
Os discípulos de Zeuner, que já haviam brilhado nas capas e ilustrações de contos e livros, como autodidatas, agora executavam trabalhos pragmáticos dentro da difícil técnica de vender produtos através de imagens objetivas e diretas, atividade não valorizada por eles, por não ter o status de profissão reconhecida. ${ }^{64}$

A criação de anúncios comerciais não depende diretamente do reconhecimento público do artista. Liga-se antes à eficácia da mensagem visual e textual, ao predomínio da informação visual e não da expressão visual, mas não negamos que essa atribuição possa vir a ser uma estratégia adotada para valorizar o produto anunciado. Enfatizamos que essa nossa hipótese dirige-se aos anúncios divulgados nos periódicos, e não aos cartazes, pois além da sua visibilidade ser outra e mesmo sendo um veículo efêmero, ele não se dilui e se confunde nas páginas de uma publicação, sem contar que os cartazes, sobretudo no período estudado, eram agraciados com valores de arte por sua proximidade à pintura, como se pode verificar numa crônica de Guilherme de Almeida dirigida a um cartaz de Di Prete:

\section{Um cartaz}

Para-se na rua para ver uma vitrina, um incêndio, uma prisão, um desastre, ou então uma linda mulher (que é tudo isso ao desastre) ... Pela primeira, vez na minha vida, eu parei e vi gente parar na rua, anteontem, para ver ... o que? -- A coisa feita expressamente para ser vista e que, de tão feia e inexpressiva sempre, jamais consegue o que pretende: um cartaz.

Como o táxi, que me levava, corresse ao longo de um tapume para tomar, à direita um viaduto, vi, sobre o pinho pintado de alcatrão, uma pequena, deliciosa, raríssima obra de arte. Um quadro - um pastel - de linhas seguras e novas, tons de doce harmonia, composição sugestiva. Dei ordem ao "chauffeur" que parasse: e fiquei uns instantes (aqueles poucos que me permitiu o "grilo") olhando a adorável coisa, como se olha, numa galeria de arte a tela que seduz. E vi, adiante, à frente de outros tapumes, grupos parados, olhando o mesmo cartaz, o cartaz "certo": isto é, fascinante e, pois, eficiente. Não sei o nome do desenhista; ignoro se foi, ou não, o resultado de um concurso entre artistas especializados. Tudo o que sei, tudo o que não ignoro é que esse é o primeiro cartaz nacional, que conheço, digno de ser visto; o primeiro que, em vez de emporcalhar, enfeita a cidade; o primeiro que dá a essa feição da publicidade fôros de Arte; o primeiro que a gente até gostaria de levar para casa e ter enquadrado no canto predileto do seu "studio", numa lógica convivência com o óleo a aquarela (sic.); a gravura que põem um sonho nos olhos abertos... É o prestigioso convite para o Grande Prêmio "São Paulo", a ser corrido depois de amanhã no

\footnotetext{
${ }^{64}$ Maria Helena Steffens de Castro, op. cit., p. 29.
} 
Hipódromo de Pinheiros;- um rosto de mulher moderna, esmaecido num mistério calmo, traçado por quem entende, mesmo de mulher, de beleza, de moda, de elegância e de "arte do cartaz", formando o primeiro plano, sobre um fundo vago de "landscape" turfista com vivo e feliz movimento e jogo sábio de tons.

Isso é um Cartaz (a maíuscula impõe-se). Ao lado dele, por aí, esses horrores degradantes que ... Mas nem é bom falar.

Temos uma Prefeitura, temos uma Associação Paulista de Propaganda. Esta ou aquela, ou aquela e esta, entrosadas, bem poderiam estabelecer um prêmio anual ao melhor cartaz que dignificasse o nosso renome de cidade civilizada. Seria, pelo menos, uma oportunidade para ... “fazermos o nosso cartaz"... ${ }^{65}$

Como vimos, os artistas jovens e inexperientes da Seção de Desenho primeiro se consagraram como ilustradores e só depois se afirmaram como pintores ou artistas plásticos. Essa visão é hierárquica e assinala uma evolução desejável no desenvolvimento artístico, pelo menos esperada no período em questão e no circuito artístico existente do Rio Grande do Sul.

O próprio João Fahrion dá o seu parecer sobre as hierarquias artísticas quando menciona que o:

ensino artístico sobretudo concorre para criar um núcleo sempre crescente de difusão artística pelos que se exercitam no apuro das suas aptidões artísticas. Mesmo quando a maioria dos assim iniciados não pretende ou não pode praticamente se admitir em dedicar-se às Artes, como artistas executantes e livres, ficarão ainda o ensino e as atividades múltiplas que exigem o preparo técnico-artístico, seja na indústria, na imprensa (jornalística e editorial), ou então acomodar-se em setores oficiais especializados. $^{66}$

A Revista do Globo como também outras revistas de variedades do período nos permitem lançar a hipótese de que os artistas foram formados propriamente para a execução de capas e ilustrações, ficando o cartaz e o anúncio para um segundo plano, de modo que, diferentemente do que se passou na Europa, nós não tivemos uma cultura voltada especificamente para o cartaz.

\footnotetext{
${ }^{65}$ Guilherme de Almeida, “Um cartaz”, Rio de Janeiro, 30 abr. 1948, p. 3. Recorte de jornal localizado na Divisão de Pesquisa do Arquivo Multimeios da SMC-PMSP do Centro Cultural São Paulo. Trata-se de um copyright do Diário de S. Paulo.

${ }^{66}$ Carla Fernanda Fontana, op. cit., p. 135.
} 


\subsection{HIERARQUIAS ARTÍSTICAS: ARTES MAIORES X ARTES MENORES}

Caricaturista, pintor, artista gráfico, desenhista e ilustrador, nos anos aqui tratados, eram categorias artísticas que se confundiam e eram exercidas concomitantemente, sendo assim não é possível estabelecermos divisões precisas para as mesmas. Ademais, nossa preocupação não é a construção de um esquema que classifique com exatidão a atuação desses artistas, ${ }^{67}$ mesmo porque é factual essa pluralidade, decorrente principalmente de um mercado em formação e que, portanto, se encontra desprovido de profissionais habilitados para o exercício de suas novas demandas, a exemplo das atividades que gravitam em torno das artes gráficas. Ao contrário, nossa intenção caminha no sentido de compreender os porquês dessa situação, sem, contudo, desviarmos por demais do nosso objetivo principal, ou seja, a averiguação da participação dos artistas plásticos na propaganda comercial brasileira.

Se a multiplicidade de atuações desses artistas, e como vimos também dos homens das letras, dificulta um agrupamento acertado em torno das atividades por eles executadas, por outro lado, enriquece o exame do mercado de trabalho desses profissionais, principalmente por recuperar momentos da formação de "novos metiês" artísticos, que surgiram, neste estudo em particular, em função da transformação da imprensa periódica e de uma industrialização nascente que carregava consigo novos meios de divulgação comercial que apostavam na relação direta entre oferta e procura, ainda que distante das programadas operações de marketing. ${ }^{68}$

A existência de atuações diversas, incluindo a produção de anúncios publicitários, nos faz pressupor que ocorreram posicionamentos e motivações diferentes para executá-las, o que para alguns artistas pode ter sido um terreno de experimentação e, portanto de predileção, foi para outros uma atividade marginal e de curta duração, possivelmente por estar associada a prementes necessidades financeiras.

\footnotetext{
${ }^{67}$ No apêndice deste trabalho, encontram-se formalizadas três categorias de tabelas, que reúnem informações acerca das várias atividades que os artistas por nós estudados exerceram. Observamos que nem sempre foi possível "encerrar" o artista em uma principal atividade profissional, pois no decorrer do tempo ocorreram alterações de interesses e de percursos. Explicando melhor, são freqüentes os casos em que o artista inicialmente se dedica à caricatura e/ou à ilustração ou mesmo aos desenhos publicitários, mas com o passar dos anos se define por outras modalidades artísticas, geralmente a pintura. Deste modo, sempre considerando a delimitação temporal proposta no estudo (1920-40), optamos por eleger para esta análise, a atuação mais constante do artista conjuntamente à sua formação artística.

${ }^{68} \mathrm{O}$ nascimento oficial do marketing enquanto disciplina ocorreu em 1950 nos EUA.
} 
Como veremos, as variáveis que se interpõem na análise desse mercado de trabalho são muitas vezes de naturezas e objetivos distintos gerando uma intrincada rede de informações, que inclui os âmbitos sociológico, histórico, artístico e estético. Essas mesmas variáveis não se originam e se circunscrevem tão somente no espaço temporal estabelecido, 1920-1940. Ao extrapolarmos esses limites, optamos por melhor entender e acompanhar o cenário artístico brasileiro, centralizado em sua maior parte no eixo Rio-São Paulo, para assim efetivar um aprofundamento do assunto.

O artista Eliseu Visconti, que por volta de 1920 criou um cartaz para a CoMP ${ }^{\underline{I A}}$ ANTARCTICA [FIG. 29, c. 1920] entre outros, parece ser um caso emblemático para iniciarmos nossa análise. Em 1901,

recém chegado de sua bolsa de estudos em Paris, Visconti não hesitou em fazer uma exposição de quadros a óleo onde colocava em igualdade de destaque com as telas, vários estudos para vitrais, estamparias de tecidos e papel de parede, pratos de cerâmica e até projetos para luminárias. Arte decorativa, demonstrava o artista, não é uma arte menor. “A arte decorativa é a procura do belo nos objetos usuais”, ensinava ele. Em vão. A exposição foi um fracasso de crítica e de público, acostumados que estavam a separar as chamadas "Belas Artes" das coisas ditas contaminadas pelo comércio. ${ }^{69}$

Sobre essa mesma exposição, se manifestaria Gonzaga Duque na revista

\section{Kosmos:}

Chamar-se-ia indiferença o quase silêncio que assediou a admirável exposição desse belo artista, se outro fosse o nosso meio social. Com melhor cabimento dir-se-á - incompreensão - esse menosprezo em que foi tida uma das mais completas, das mais importantes exposições de arte aqui franqueadas ao público.

Incompreensão e inoportunidade. Inoportunidade porque a hora é das piores, o dinheiro escasseia às bolsas mais volumosas, a existência tornou-se penosa aos melhores aquinhoados da sorte, e incompreensão porque Eliseu Visconti é um artista sincero e honesto, enobrecido por um ideal a que a vulgaridade não atinge.

Visão de idealista e espírito refletido de analisador, sensibilidade requintada e ponderação desenvolvida, lhe deram um equilíbrio que,

\footnotetext{
${ }^{69}$ Angélica de Moraes, "Visconti, um artista até nos rótulos de propaganda", Zero Hora, Porto
} Alegre, 19 dez. 1983. 
raras vezes, se observa, tornando-o um profissional de incontestável valor.

\section{$[\ldots]$}

Agora, que ele alcançou sua maneira definitiva, porque hoje em dia o artista não se limita a um determinado processo pictural como entre os antigos, esses motivos, de dificílima reprodução, constituem a acentuada característica do seu individualismo que se destaca, em conjunto, pela pureza duma arte desviada das perturbações eróticas da contemporaneidade, arte serena e humana - que fala ao espírito, que alivia o coração com uma doçura só facultada aos que têm os olhos postos na claridade dum futuro próximo.

E foi por este ideal enobrecedor que ele chegou à arte decorativa, conquistando seus segredos n'aprendizagem do famoso atelier Grasset.

É necessário atenuar os violentos efeitos da nossa civilização, adelgaçar a rudeza do utilitarismo com a mão macia e branda da graça. É necessário trazer ao delírio industrial destes tempos, que foi o espectro de Ruskin, as miragens do engano e da compensação, domando a ferocidade humana com o deslumbramento da forma e da cor, para que se não perca de todo o resto de generosos sentimentos ainda existentes na espécie soberana sobre a Terra...

É de lamentar, no entanto, que as indústrias no Brasil vivam, mesquinhas e foscas, na servilidade dos maus modelos vindos do estrangeiro, porque, se assim não fosse, encontrariam em Eliseu Visconti o espírito animador de seus produtos, o criador de sua originalidade, de seu mérito artístico, desde que o governo, distraído dos seus deveres, encharcado de politicagem, não saiba aproveitar numa utilíssima Escola ou, pelo menos, numa aula de arte decorativa para honra e proveito nosso. ${ }^{70}$

Se o assunto como apresentado por Gonzaga Duque parece ser uma questão emergente do início do século passado, na realidade não é e tampouco se resolveu naqueles idos, pois em 1926 os depoimentos de Henrique Cavalleiro, Marques Júnior e do próprio Eliseu Visconti, reunidos no livro Inquietação das Abelhas, continuam reforçando a necessidade dos estudos de arte decorativa, das artes aplicadas direcionadas aos produtos da indústria nacional. ${ }^{71}$ Mas, mais ainda, Visconti, somente viria a realizar parcialmente esse seu desejo em 1934, quando criou a disciplina de

70 O artigo também se encontra em Gonzaga Duque, Contemporâneos (pintores e esculptores), Rio de Janeiro: Typ. Benedicto de Souza, 1929, pp. 19 e 26.

${ }^{71}$ Ver Angyone Costa, Inquietação das abelhas, Rio de Janeiro: Pimenta de Mello \& Cia, 1927, pp. 79-80, 125-126, e 172-173. 
Composição Decorativa para o Curso de Arte Decorativa - Extensão da Universidade do Rio de Janeiro, anexo à Escola Politécnica, onde lecionou até 1943.

A possível polêmica em torno das artes aplicadas e sua colaboração às indústrias brasileiras, o que também deveria incluir as artes gráficas, não se iniciou com Visconti, e excluindo os artífices que chegaram ao Brasil com a Missão Francesa com o objetivo de instaurar uma educação artística voltada antes à formação artesanal e industrial do que propriamente às belas artes, podemos mencionar a Reforma de Araújo Porto Alegre (1854), ${ }^{72}$ diretor da Academia Imperial de Belas Artes (AIBA), que propôs uma “retomada” da colaboração das artes à produção industrial, por meio do ensino técnico, amparado nas “artes do desenho”, isto é, no desenho geométrico e no de ornatos, afora as aulas de matemáticas aplicadas e de escultura de ornatos. Todavia, para a época e mesmo para Porto Alegre o termo indústria estava muito mais próximo das atividades manufatureiras do que propriamente das industriais.

Segundo Leticia Squeff o projeto de Porto Alegre foi inovador por permitir que a Academia abrisse duas frentes de formação - uma dedicada ao ensino técnico e outra ao artístico, porém o projeto de reforma não se realizou plenamente e a procura pelo ensino técnico foi tímida, ${ }^{73}$ a qual pode ter sido agravada pelo fato de, em 1857, o Liceu de Artes e Ofícios do Rio de Janeiro (LAO/RJ) iniciar suas atividades oferecendo um curso completo de desenho aplicável a todos os ofícios industriais com a finalidade de formar artífices e operários para a indústria nacional. ${ }^{74}$

No plano internacional, esperava-se que o aprendizado da arte, mais especificamente das noções do desenho, direcionado aos cursos profissionalizantes proporcionasse o aperfeiçoamento e a capacitação dos operários para desenhar e executar os projetos fornecidos pelos artistas; no entanto, devemos considerar que no Brasil do período três fatores dificultariam o sucesso desse empreendimento:

- o reduzido número de indústrias;

\footnotetext{
${ }^{72}$ Autores questionam se a reforma da AIBA foi mesmo do ministro do Império, Luiz Pedreira do Couto Ferraz ou de Porto Alegre, diretor da instituição.

${ }^{73}$ Leticia Squeff, O Brasil nas letras de um pintor: Manuel de Araújo Porto Alegre (18061879), Campinas: Editora da UNICAMP, 2004, p. 197.

${ }^{74}$ Consultar Frederico Morais, Cronologia das artes plásticas no Rio de Janeiro 1816 - 1994, Rio de Janeiro: Topbooks, 1995, p. 82. O LAO/RJ deveria proporcionar a "todos os indivíduos, nacionais e estrangeiros, o estudo de belas-artes e sua aplicação necessária aos ofícios e às indústrias”, mas na prática ele se voltou ao ensino das artes por não dispor de oficinas. Ver Luiz Antônio Cunha, "O ensino industrial-manufatureiro no Brasil", Revista Brasileira de Educação, São Paulo, (14): 92, maio - ago. 2000.
} 
- o baixo nível artístico e cultural dos freqüentadores da AIBA, pois nossa academia era composta de "professores de saber e cultura desiguais, alunos de origem humilde e instrução deficitária, um curso pulverizado por brigas internas e pela falta geral de um método de ensino”. ${ }^{75}$ Essa situação só viria a melhorar a partir de 1860 com a atuação de artistas como Vítor Meireles, Pedro Américo e Agostinho José da Mota;

- o preconceito vigente na época contra o trabalho manual, que era uma atividade executada principalmente pelos escravos e por aqueles homens livres em estado de mendicância, jovens órfãos ou abandonados. ${ }^{76}$

Além disso, Porto Alegre ia de certo modo à contramão da atuação das academias européias, que excluíam de seu ensino as atividades técnicas ou manuais, a exemplo e, sobretudo da francesa da qual éramos seguidores. Portanto, pensar que nesses anos a parceria entre arte e indústria teria gerado um debate profícuo entre a AIBA e a sociedade não nos parece correto. Por melhores intenções que Porto Alegre tenha tido - apoiadas ou mesmo "sugeridas" pelo ministro Pedreira -, em verdade o que se passou foi uma tentativa de adequação das artes ao meio forjada pelo clima eufórico do progresso. O que fica claro no discurso de sua posse:

vossa missão será bem mais modesta, porém mais útil e necessária à atualidade: pertence à organização dos estudos, a preparar solidamente essa mocidade que deve servir ao país; antes do artista se deve preparar o bom artífice, assim como antes deste já deve existir o necessário artesão. $^{77}$

\footnotetext{
${ }^{75}$ Ver Letícia Squeff, op. cit., pp. 79 e 187-188. Para ampliar esse quadro deficitário da AIBA, a autora menciona que até 1837 somente dois professores sabiam ler e escrever corretamente e que só um dos professores sabia geometria, porém o mesmo não sabia perspectiva. Acrescentase que os professores da AIBA ganhavam salários baixos, um pouco acima dos trabalhadores rurais, o que os obrigava a realizarem outros trabalhos, até mesmo ligados ao comércio.

${ }^{76}$ Os escravos trabalhavam como carpinteiros, pedreiros, calceteiros, impressores, litógrafos, pintores de cartazes e ornatos, fabricantes de carruagens e escrivaninhas. No caso dos homens livres citamos as instituições Colégio das Fábricas (1809) e o Asilo dos Meninos Desvalidos (1875) que proporcionavam a aprendizagem dos ofícios e o trabalho como artífice. No asilo "recebiam a instrução primária, seguida de disciplinas especiais (álgebra elementar, geometria plana e mecânica aplicada às artes; escultura e desenho; música vocal e instrumental) e aprendiam um dos seguintes ofícios: tipografia, encadernação, alfaiataria, carpintaria, marcenaria, tornearia, entalhe, funilaria, ferraria, serralheria, courearia ou sapataria”. Sobre o assunto consultar Luiz Antônio Cunha, op. cit., p. 91.

${ }^{77}$ Apud Letícia Squeff, op. cit., pp. 187-188.
} 
Essas palavras também explicitam a confusão conceitual da época em torno dos termos industrial e manufatureiro, reafirmando que na prática os objetivos de Porto Alegre estariam voltados às atividades manufatureiras e, portanto sua proposta de ensino técnico para a academia estaria distante das necessidades que envolvem os processos técnicos de fabricação industrial e que exigem um outro perfil profissional, o do desenhista industrial. Mas, essa falta de clareza também ocorreu no plano internacional, ou seja, uma indefinição quanto à distinção entre a formação em um ofício e a formação em artes aplicadas. ${ }^{78}$

Se o insucesso da exposição de Visconti revela um meio despreparado para acolher as artes aplicadas, que se mantém na subserviência de modelos importados, ${ }^{79}$ efetivamente, indica uma sociedade que ainda não conseguiu ou não soube criar mecanismos para inserir adequadamente a arte a serviço das suas indústrias e, tampouco exercitou-se no aprimoramento e na difusão do bom gosto. Neste caso é fundamental um projeto educacional amplo que inclua encomendas de obras de arte, publicações de menor custo, construção de edifícios e monumentos públicos, museus, entre outros investimentos de mesma natureza. ${ }^{80}$

Uma comparação com o quadro internacional, que, inicialmente, também enfrentou dificuldades em conferir qualidades artísticas aos seus objetos industrializados, de imediato aponta que o problema maior advinha da ausência do ensino do desenho nas escolas primárias e secundárias.

Considerando este fator, as reformas do ensino brasileiro que foram propostas no período, sobretudo as de Rui Barbosa, ${ }^{81}$ guardam uma proximidade com as discussões que ocorriam no plano internacional. Porém as reformas, que poderiam proporcionar

\footnotetext{
${ }^{78}$ Nikolaus Pevsner, Academias de arte: passado e presente, São Paulo: Companhia das Letras, 2005, p. 288.

${ }^{79}$ Apesar do pioneirismo de Visconti na área das artes decorativas aplicadas à indústria, Frederico Barata lamenta sua forte ligação com a tradição européia, que distanciou o artista dos motivos brasileiros. Sobre essa questão, ver o catálogo da exposição Eliseu Visconti e a arte decorativa, Rio de Janeiro: PUC/FUNARTE, 1983, p. 112.

${ }^{80}$ Cabe notar, que até então, esse descomprometimento não era somente com as ditas artes menores, pois Araújo Porto Alegre já chamava a atenção para o fato de não existirem mecanismos de absorção na sociedade do trabalho dos artistas vinculados a uma arte maior, a exemplo das encomendas de obras públicas.

${ }^{81}$ Os modelos de implantação do ensino da arte, que se resumiam ao ensino do desenho, nas escolas primárias e secundárias estavam baseados nas idéias de Rui Barbosa expressas em seus Pareceres sobre a Reforma do Ensino Secundário e Superior (1882) e sobre a Reforma do Ensino Primário (1883) de Leôncio de Carvalho. Sobre o assunto consultar Ana Mae T. B. Barbosa, Arte-educação no Brasil: das origens ao modernismo, São Paulo: Perspectiva, 1978, pp. 43-63.
} 
mudanças de consciência e de atuação artística de nossos profissionais, nunca saíram do projeto e do papel, e o ensino do desenho -“linguagem da técnica e da ciência”-, que em outros países abriu espaços e proporcionou alterações no panorama das artes aplicadas originando o design, no Brasil, foi encaminhado de um modo que nos distanciou naqueles idos de uma arte verdadeiramente aplicada às nossas indústrias, como explica Ana Mae Barbosa ao comentar as propostas de Rui Barbosa. Estas, apesar de não apresentarem

nenhuma originalidade, foram resultado de uma longa pesquisa: "usando de uma cultura especializada e técnica até então desconhecida entre nós” - e vasta fundamentação bibliográfica, articulava exemplarmente os modelos estrangeiros no sentido de sua adaptação ao Brasil. Seus planos, exeqüíveis e de grande validade se aplicados, teriam retirado de imediato escolas secundárias e primárias da influência asfixiante da Academia de Belas-Artes, colocando-as sob a orientação das Escolas Normais de Arte Aplicada. Possivelmente, isto teria criado condições para acelerar o processo de dicotomia entre Arte e Técnica, já delineado àquele tempo e que estava implícito no pensamento de Rui quando afirmava a necessidade da existência de uma Academia de BelasArtes para o cultivo superior da Pintura e Desenho, de uma Escola Normal de Arte Aplicada para o cultivo das formas de arte aplicadas à indústria. Isto apesar de sempre colocar em destaque a importância do Desenho geométrico e industrial como meio não só de educar para o trabalho como também de desenvolver valores estéticos e espirituais, como se pode depreender de um discurso proferido no Liceu de Artes e Ofícios em 1822 [sic.]. A Teoria da Expressão, baseada nas “Artes Menores” de William Morris que, como Rui Barbosa, demonstrava enorme entusiasmo pela atuação do Museu de South Kensington, é a que mais se aproxima do seu processo de entender Arte e Indústria - uma espécie de utopia sentimental. ${ }^{82}$

O lento processo de reformulação do nosso ensino das escolas primárias e secundárias, que se estendeu até meados dos anos vinte foi influenciado ora pelos políticos liberais ora pelos positivistas, proporcionando duas frentes de ensino das artes que se fundamentavam no desenho técnico (desenho geométrico, escola americana) e no desenho decorativo (desenho de ornatos, escola francesa). Nesse decurso, no ensino da arte, sobretudo nas escolas secundárias, predominou a aprendizagem do desenho geométrico que recebeu fortes influxos matemáticos. Por sua vez, a herdeira da AIBA, a Escola Nacional de Belas Artes do Rio de Janeiro (ENBA/RJ) mantinha-se num ensino

\footnotetext{
${ }^{82}$ Idem, pp. 62-63.
} 
acadêmico e burocratizado e numa posição de inércia por formar unicamente pintores de cavalete, escultores de estátuas e de bustos e gravadores de medalha, como observa, em 1915, o professor Modesto Brocos, defensor de um ensino profissional que incluísse a arte decorativa, que a seu ver seria “o primeiro degrau que deve galgar todo o moço que se destina às Belas Artes”. Logo, desenvolvia-se a idéia que a formação de todo e qualquer artista deveria ocorrer inicialmente pelo viés artesanal, com o objetivo de tornar o aprendizado na escola prático e útil, o que por sua vez contribuiria para a indústria nacional. ${ }^{83}$ No entanto, para a ENBA/RJ a arte decorativa confundia-se com o ornato, como um elemento meramente “adicional” à obra e não como uma qualidade da superfície da pintura.

No contexto europeu a reflexão crítica, a valorização do desenho como disciplina, ainda que entendido como cópia, e sua aplicação na comercialização dos produtos $^{84}$ têm suas origens na Inglaterra do século XVIII como resposta aos procedimentos industriais e às técnicas de produção em série, conseqüências estas da Revolução Industrial. ${ }^{85} \mathrm{E}$ são esses mesmos interesses comerciais que estimulam a partir de 1750 a proliferação de academias e escolas de arte.

As reorganizações das academias de Viena, Dresden e Berlim expuseram claramente que as intenções comerciais deveriam ser acompanhadas de motivações artísticas, como se pode verificar no regulamento de 1790 da Academia de Berlim que

define como sua missão contribuir para o bem-estar das artes em geral, incentivar e promover as indústrias nacionais e, por sua influência na manufatura e no comércio, contribuir para aperfeiçoá-las a tal ponto que o gosto dos artistas prussianos deixe de ser inferior ao dos estrangeiros. ${ }^{86}$

Na França, ao contrário, desde o século XVIII foram as escolas privadas que ficaram encarregadas do ensino do desenho e das artes de um modo geral direcionada

${ }^{83}$ Quirino Campofiorito, “Artes industriais e as tradições do ensino artístico no Brasil”, Arquivos da Escola Nacional de Belas-Artes, Rio de Janeiro, (9): 75-76, 12 ago. 1963.

${ }^{84}$ Segundo Pevsner, em 1800, as exigências industriais para com os artistas eram antes de tudo uma questão de transposição dos desenhos para diversos materiais com o auxílio de diferentes ferramentas e não, como hoje entendemos, ou seja, o conhecimento íntimo dos materiais empregados e do processo de trabalho, que conduzem ao metiê do desenhista industrial. Consultar Nikolaus Pevsner, op. cit., pp. 218-219.

${ }^{85} \mathrm{Na}$ Inglaterra, Josiah Wedgwood (1730-1795) foi precursor das técnicas de produção em série e um dos primeiros a ter consciência da importância do desenho para a fabricação de bens de consumo, tanto que empregou artistas como o escultor John Flaxman, o pintor George Stubbs e muitos ceramistas italianos.

${ }^{86}$ Nikolaus Pevsner, op. cit., p. 203. 
aos artesãos ou fabricantes/operários, pois as academias se dedicavam exclusivamente às belas artes. Assim a formação em artes aplicadas nos anos iniciais do século XX deve-se principalmente à atuação da École Nationale des Arts Décoratifs ${ }^{87}$ com cursos de desenho, modelagem e decoração. Como atesta Pevsner:

é importante ressaltar que, no país, continuava a imperar uma poderosa academia, que mantinha filiais provinciais e não se importava com as exigências específica dos ofícios; já na maior parte dos outros países da Europa, especialmente na Alemanha, ou as instituições acadêmicas assumiram o ensino das novas profissões, ou criaram-se novos estabelecimentos com o objetivo de atender ao mesmo tempo a finalidades artísticas ou comerciais. ${ }^{88}$

Por sua vez, o ideal romântico do século XIX questionou o fato das academias estarem vinculadas a objetivos comerciais, de modo que

os rudimentos do desenho passaram a ser ensinados nas escolas primárias e secundárias, deslocando-se o desenho industrial para as escolas técnicas, os cursos profissionalizantes ou as escolas municipais de arte. Em cerca de meados do século XIX, outra separação se fez necessária: entre os estudantes de arte e aqueles dos cursos técnicos em todos os ramos. Em virtude do desenvolvimento sem precedentes da indústria e da técnica, alguns países criaram departamentos de ensino técnico especializado nas universidades, outros abriram Technische Hochschulen. Isso desobrigou até certo ponto as escolas profissionalizantes de prover tal tipo de ensino, sem que se definisse uma distinção entre a formação de um ofício e a formação em artes aplicadas. $^{89}$

O encaminhamento conferido a esse assunto por parte dos países que vivenciaram de modo direto ou mais de perto a Revolução Industrial, decorreu de necessidades prementes de suas indústrias que ao, reconhecerem o gosto duvidoso de seus produtos, pesquisaram e efetivamente programaram soluções para os problemas identificados. Todavia, nós nos mantivemos praticamente à parte dessas necessidades, entre outras causas, devido a uma incipiência industrial que nos empurrou à importação de produtos, modelos e idéias, mas por outro lado, a essa discussão nos agarramos pela

\footnotetext{
${ }^{87}$ A École Nationale des Arts Décoratifs é descendente da escola de Bachelier fundada no século XVIII. Sobre o assunto consultar Idem, p. 210.

${ }^{88}$ Idem, pp. 211-212.

${ }^{89}$ Idem, p. 288.
} 
possibilidade de estarmos "filiados" a uma mentalidade progressista que circulava internacionalmente.

Em 1909, com Nilo Peçanha na presidência, foram criadas as escolas de aprendizes e artífices, situadas uma em cada estado. Segundo Luiz Antônio Cunha essa iniciativa visava:

a formação de operários e contramestres, através de ensino prático e conhecimentos técnicos necessários aos menores que pretendessem aprender um ofício em "oficinas de trabalho manual ou mecânico que forem mais convenientes e necessários ao estado em que funcionar a escola, consultadas, quando possível, as especialidades das indústrias locais”. Como parte integrante de cada escola de aprendizes artífices, foram criados cursos noturnos obrigatórios, um primário (para os analfabetos) e outro de desenho (para alunos que dele precisassem). ${ }^{90}$

Porém, essas escolas centralizavam o ensino dos ofícios nas modalidades de marcenaria, alfaiataria e sapataria ficando bem distantes dos propósitos industrialistas, e muito mais próximos dos artesanais, sem contar que poucas delas dispunham de instalações apropriadas ao ensino de ofícios industriais. Em São Paulo, decorrente do crescimento da produção industrial, as escolas de aprendizes e artífices ofereciam cursos de tornearia, de mecânica e de eletricidade, e os voltados para o artesanato como o de carpintaria e o das artes decorativas, mas não ensinavam os ofícios de sapateiro e de alfaiate. $^{91}$

Foi na Alemanha que as artes aplicadas às indústrias obtiveram melhor resultado a partir da Bauhaus (1918), pois esta entendeu que não era somente uma questão do ensino do desenho nas escolas primárias, secundárias e de ofícios. Foi levando mais à frente as teorias de William Morris - “a relação orgânica entre material, processo, objetivo e forma estética” - que a Bauhaus soube fazer a passagem do artesão de arte para a do desenhista industrial, bem como a unificação das belas artes, do artesanato e da arte industrial, possibilitando um novo conceito de educação artística. ${ }^{92}$

Pelo exposto até agora, a discussão em torno das artes aplicadas no Brasil, em seu todo, parece ser uma questão importada, não só pelo seu alcance reduzido, mas também por sua inexeqüibilidade nos anos mencionados, visto que as nossas poucas

\footnotetext{
${ }^{90}$ Luiz Antônio Cunha, op. cit., p. 95. O autor menciona que em 1911 o ensino do desenho se tornou obrigatório a todos os alunos do curso.

${ }^{91}$ Idem, p. 96.

${ }^{92}$ Nikolaus Pevsner, op. cit., pp. 301, 313 e 328.
} 
instituições de ensino das artes não tiveram condições reais de se engajaram nesse complexo debate. Depreende-se também que as artes gráficas ocupavam um espaço menor nesse contexto teórico, porém, não podemos excluir a diversidade e o importante papel “assumido” pelas revistas ilustradas desde meados do século XIX na constituição de núcleos profissionais que têm por característica a combinação simultânea do aprendizado e do trabalho. Essas publicações se tornaram oportunidades reais de formação para os nossos artistas, que também puderam contar com a experiência dos profissionais estrangeiros e com a circulação de publicações internacionais.

Um breve mapeamento dos principais acontecimentos em torno das artes aplicadas que ocorreram no eixo Rio-São Paulo revela um longo processo de implantação da questão que culminaria no design (visual e industrial). Verificamos que a partir da década de 1930 as tentativas se adensam, mas somente a partir da década de 1950 é que ganhará contornos profissionais. Assim, elencamos:

- 1857: Liceu de Artes e Ofícios do Rio de Janeiro

- 1882: Liceu de Artes e Ofícios de São Paulo; ${ }^{93}$

- 1887: I Exposição Industrial e Artística, Palácio Cristal, Petrópolis;

- 1901: Mostra de Eliseu Visconti, RJ;

- 1917: Exposição de desenhos para reclame de Umberto Della Latta, SP;

- 1929: Exposição de Arte Decorativa Alemã, organizada pela Deustcher Werkbund, RJ e SP;

- 1930: Exposição Alemã de Livros e Artes Gráficas, RJ e SP;

- 1933: Lançamento da revista base: revista de arte, técnica e pensamento; ${ }^{94}$

- 1934: Eliseu Visconti ministra a disciplina de Composição Decorativa para o Curso de Arte Decorativa - Extensão da Universidade do Rio de Janeiro, anexo à Escola Politécnica, onde lecionou até 1943.

- 1935: Criado o Instituto de Artes da Universidade do Distrito Federal; ${ }^{95}$

\footnotetext{
${ }^{93} \mathrm{O}$ LAO/SP tinha por objetivo "formar artesãos e trabalhadores para as oficinas, o comércio e a lavoura" e faziam parte de seu currículo o ensino de "aritmética, álgebra, geometria descritiva, zoologia, física e suas aplicações; mecânica e suas aplicações; agrimensura, desenho linear, desenho de figura, desenho geométrico, desenho de ornato, de flores e de paisagens, desenho de máquinas, desenho de arquitetura, caligrafia, gravura, escultura de ornatos e arte, pintura, estatuária, música, modelação e fotografia”. Disponível no site www.liceuescola.com.br. Observa-se que de modo geral não se pensava especificamente no ensino das artes gráficas.

${ }^{94}$ Alexandre Altberg, redator-chefe da revista base, introduz no Brasil os princípios da Bauhaus. O terceiro número da revista é dedicado à propaganda. Ver Frederico Morais, op. cit., p. 149.
} 
- 1940: Exposição O desenho na imprensa moderna, Casa do Estudante do Brasil, $\mathrm{RJ}{ }^{96}$

- 1946: Curso de Arte Decorativa na ENBA/RJ;

- 1946-1947: Curso de Desenho de Propaganda e Artes Gráficas na Fundação Getúlio Vargas, RJ; ${ }^{97}$

- 1950: $1 .^{0}$ Salão Nacional de Propaganda, MASP, SP;

- 1950: A Lei nº 899 de 28.11. 1957 cria definitivamente o Instituto Municipal de Belas Artes, RJ, “destinado 'a ministrar, divulgar e incrementar o ensino das artes plásticas e suas aplicações técnicas e industriais com a finalidade de desenvolver a capacidade do artífice e aprimorar vocações artísticas’. Foram previstos cursos regulares de pintura, escultura, gravura de medalhas e pedras preciosas, artes de prensa, história da arte, elementos de arquitetura, artes decorativas"; 98

- 1951-1952: Curso de arte publicitária no Instituto de Arte Contemporânea do MASP, SP. Iniciativa que impulsionou a criação da Escola de Propaganda de São Paulo (1955), que em 1970 adotou o seu nome atual - Escola Superior de Propaganda e Marketing (ESPM);

- 1953: Alexandre Wollner freqüenta a Escola Superior de Criação de Ulm, e mais tarde será um dos responsáveis pela implantação da profissão de designer no Brasil;

- 1962: A Faculdade de Arquitetura e Urbanismo da Universidade de São Paulo (FAU/USP) cria as disciplinas de Comunicação Visual e Desenho Industrial, substituindo a de Composição Decorativa;

\footnotetext{
${ }^{95}$ Seu diretor, Celso Kelly, "lembrava, em 1961, que dentre as inovações fundamentais do Instituto constavam duas coisas profundamente significativas: uma delas era a unidade de ensino artístico enveredando pelas artes industriais, inclusive e especialmente as artes gráficas e a decoração de interiores”. Idem, p. 154.

${ }^{96}$ Mostra que reuniu charges, caricaturas, publicidade, figurinos e ilustrações, e debateu sobre a especialização e profissionalização dos artistas que trabalhavam na imprensa, bem como a concorrência estrangeira nas revistas infantis. Críticos apontam o declínio da colaboração dos nossos desenhistas no jornalismo e também a fraca seção da publicidade. Idem, pp. 168-169.

${ }^{97}$ Curso que foi "previsto para durar seis meses, com três áreas: desenho aplicado às artes gráficas, elementos de história da arte e artes gráficas e técnica de publicidade. A direção e orientação geral são de Santa Rosa, que se ocupa também das aulas de composição decorativa e publicidade; Carlos Oswald ensina água-forte; Axel Leskoschek, xilogravura; e Hannah Levy, história da arte”. Idem, p. 194.

${ }^{98}$ Idem, p. 210.
} 
- 1963: A ENBA/RJ, propõe a criação de dois cursos: o Curso de Artes Industriais em substituição e atualização ao Curso de Arte Decorativa vigente e o Curso de Projeto Industrial (“Industrial Design”);

- 1963: Início do Funcionamento da Escola Superior de Desenho Industrial (ESDI), RJ.

O descompasso entre a implementação industrial e a formação do profissional brasileiro das artes gráficas, que também se ocuparia da publicidade, abriu brechas no início do século XX, para os caricaturistas, ilustradores, desenhistas e litógrafos das revistas que acabaram por conformar um meio autônomo e marginal ao ensino oficial. Esses artistas se defrontaram com a difícil tarefa de contornar as deficiências desse setor, que só a partir da década de 50 pode contar com o designer gráfico, profissional que na Europa já se esboçava desde as atividades da Bauhaus. Mas, se essa situação nos faz pressupor a existência de um espaço vazio, nada mais equivocado, pois continuamos a caminhar segundo os modelos europeus e americanos, sobretudo se levarmos em conta a contribuição também na década de 30, das agências americanas e dos profissionais estrangeiros que se transferiram para o Brasil e que imprimiram um novo padrão às peças publicitárias de naturezas diversas. Ao mesmo tempo se testemunha a gradativa organização da nova profissão - a de publicitário, que deixa menos espaço ao artista que passa doravante a fazer parte de uma equipe.

A procura de novas oportunidades de trabalho para os artistas plásticos de um modo geral vai se conformando com outras questões que circulavam no decorrer dos anos, tais como a polêmica "arte pela arte” e arte a serviço da sociedade. Se nas décadas iniciais era a adequação das artes aos produtos industrializados ou a forte demanda da imprensa que se expandia, nos anos 1930 a relação arte e propaganda se vê associada a uma função social, como notamos nas palavras de A. Xavier da Silva:

a arte procurando formas de ser útil encontra na propaganda o seu veículo natural, e compreendendo a finalidade da propaganda não vê desdouro - se não motivo de orgulho em acompanhá-la.

a propaganda é a grande construtora do conforto do povo, pois graças à disseminação do uso, o automóvel, o rádio, o livro, o jornal, tornaram-se acessíveis aos bolsos modestos. e educando o homem para um melhor "standard" de existência, a propaganda faz desejadas, apreciadas e compreendidas as belas coisas da vida.

uma revista que nos cai nas mãos é uma bíblia de ensinamentos úteis. a capa desta revista é a obra de um artista, de um artista é o texto e a parte 
tipográfica é de artista e de artista ainda é a fotografia ilustrativa dos artigos ... os anúncios mantêm esta publicação. e a arte assim casada à propaganda sente-se satisfeita por poder ser apreciada e ter uma função social, pois através dos anúncios que ela ilustra vai se fazer o conforto de mais um lar, a saúde de mais uma criança, a cessação de mais uma dor e a alfabetização de mais um cidadão.

a propaganda entre nós acha-se ainda envolta em véus de mistério, como se fosse privilégio de inspirados o criá-la e o desenvolve-la. mas a propaganda - como em tudo - não se improvisam técnicos, mas estes podem fazer-se com estudo.

por ser o melhor propagandista ninguém será capaz de desenhar as ilustrações de uma campanha de propaganda e a recíproca também é verdadeira: unicamente por ser excelente artista, ninguém está qualificado para dirigir a propaganda de qualquer produto.

os artistas e os propagandistas se completam. dêm-se, pois as mãos para o engrandecimento da arte e a elevação da vida. ${ }^{99}$

Em continuidade, indagamos se no Brasil, ou mais especificamente no Rio de Janeiro e em São Paulo, nas décadas de 1920-40, tiveram as artes aplicadas um auge ou uma participação significativa nos circuitos artístico e industrial. O quanto elas aderiram ou não às belas artes? Era uma questão já independente dos valores da ENBA/RJ?

Como vimos não dispúnhamos de um ensino e circuito artístico que realmente estivessem comprometidos com as artes aplicadas. Tentativas institucionais e individuais esporádicas que nem sempre tiveram condições e respaldo para efetivarem transformações necessárias, foram essas as incursões que constituíram a nossa história das artes aplicadas de meados do século XIX às décadas iniciais do século passado. E, mesmo o Curso de Extensão Universitária de Visconti encontrava-se defasado por ser uma adequação do ensino da arte decorativa embasado nas artes ornamentais, ou melhor, no ornato das linhas Art Nouveau, e não nas artes projetuais compromissadas com a indústria; o que bem poderia constituir um risco para a arte decorativa, por transformá-la em um produto artesanal de luxo, distanciando-se dos objetivos iniciais do movimento francês.

Nosso levantamento dos principais acontecimentos em torno das artes plásticas no Brasil, mais especificamente em São Paulo e no Rio de Janeiro, nos fornece respostas negativas; basta citarmos que somente em 1946 a ENBA/RJ criou um curso voltado às artes decorativas e, apenas em 1963, se cogitou a sua substituição por um de

\footnotetext{
${ }^{99}$ A. Xavier da Silva, “A arte e a propaganda”, base: revista de arte, técnica e pensamento, Rio de Janeiro, (3): 51, out. 1933. Número especial sobre propaganda. As letras minúsculas estão em consonância com os princípios tipográficos e racionais da Bauhaus implantados no ano de 1925.
} 
artes industriais, bem como a criação do Curso de Projeto Industrial ("Industrial Design”).

Mesmo dispondo de poucos incentivos, arriscamos a formular a hipótese de que no conjunto das aplicadas, as artes gráficas tiveram um alcance maior, em virtude de sua posição marginal no sistema de ensino institucionalizado, sem contar que o seu desenvolvimento foi forjado na imprensa livre na qual as exigências técnica e prática do trabalho obrigam-na a atualizações e a respostas rápidas. Assim, ocorreu de antemão uma absorção das conquistas européias e americanas do setor, pois conforme já mencionado a contribuição estrangeira de diversos profissionais acrescida da circulação das publicações internacionais, acabaram por “apressar” o seu progresso.

No caso específico da publicidade ainda temos que considerar que essa atualização foi forçada pelos anúncios comerciais que vinham prontos das agências matrizes. E, vale relembrarmos os comentários de EricoVerissimo sobre a prática de copiar as ilustrações das revistas estrangeiras. ${ }^{100}$

${ }^{100}$ Consultar as páginas 39-40 e a nota 34 deste capítulo. 


\subsection{IDEOLOGIAS ARTÍSTICAS}

Ao propor a convivência nas aulas do curso técnico da AIBA de dois tipos de alunos: “os artistas e os artífices, os que se dedicam às belas artes e os que professam as artes mecânicas”, ${ }^{101}$ a Reforma Porto Alegre, no seu artigo 79, determina que a formação dos alunos-artífices

ficava circunscrita somente àquelas disciplinas: matemáticas aplicadas, desenho geométrico, além dos cursos de desenho de ornatos e escultura de ornatos. Todas as outras matérias da academia eram voltadas para a formação do artista. Não se aventava a possibilidade de o aluno-artífice freqüentar os cursos destinados às belas-artes. ${ }^{102}$

As diretrizes mencionadas deixam transparecer a manutenção das hierarquias entre as artes que vigoravam no país pelo menos por parte da direção da AIBA, como também procuram reforçar o status de seus alunos-artistas pela evidente distinção de classes sociais. $^{103}$

Ainda que na época a AIBA não fosse tão bem vista pela sociedade e tampouco uma instituição importante, temos que atentar para o fato de sermos herdeiros das práticas das academias de artes francesas, nas quais a posição social do artista é fundamental na relação hierárquica entre a arte maior e a arte menor, o que equivale a dizer que o artista que faz parte da academia teria uma posição social mais elevada, afastando-se das artes aplicadas. À medida que a nossa academia de arte passa a ser respeitada e se impor no meio artístico e cultural, as questões hierárquicas ganham força, permanecendo no decurso do tempo mesmo sob a vigência da ENBA/RJ. E nesse caso, novamente Visconti se torna exemplar, pois segundo Campofiorito:

O artista projeta belos e variados objetos no gosto da época, para serem fabricados. A indiferença do ambiente e o combate que lhe movem os responsáveis pelo ensino oficial por demais academisado, levam-no a desinteressar-se pelo projeto industrial para só se aplicar à pintura e à

\footnotetext{
${ }^{101}$ Quirino Campofiorito, op. cit., p. 74.

${ }^{102}$ Leticia Squeff, op. cit., pp. 193-194.

103 Como mencionamos anteriormente, o trabalho manual estava associado aos escravos e aos brancos órfãos, abandonados e aos miseráveis.
} 
decoração mural, únicas oportunidades que lhe eram oferecidas e então consideradas dignas para um artista. ${ }^{104}$

Se a grosso modo os nossos industriais não incentivavam a participação dos artistas em seus produtos, existiam as exceções, a exemplo das Manufaturas Ludolf \& Ludolf, para a qual Visconti executou vários desenhos para peças de cerâmica. Apesar de o artista ter recebido propostas para associar-se ao industrial, recusou-as para não ter sua liberdade de pintor prejudicada. Em 1905, uma carta do sr. Americo Ludolf a Visconti comenta:

Leio que tomou um atelier e que está trabalhando ativamente, pelo que dou-lhe minhas felicitações. Espero, entretanto, que não se deixe absorver inteiramente pela arte pura, e dispense algum tempo à nossa cerâmica. [...] O que me pertuba é justamente a falta de um auxílio de artista decorador que ajude a promover o desenvolvimento da nova indústria... ${ }^{105}$

A fidelidade de Visconti à sua formação de pintor, parece ter predominado em suas escolhas artísticas, como demonstra o depoimento de Leonardo Visconti Cavalleiro:

Não podemos classificá-lo como um autêntico designer tentando levar a denominação deste profissional para a época, visto que sua predominância pela arte impedia-o de transpor todo o seu estilo de artista puro, subjetivo e romântico, para um tipo objetivo, racional e acentuadamente lógico. Essa denominação é incompatível com Visconti, que se ocupava de uma investigação estética experimentando todas as possibilidades dos instrumentos de sua época, em busca de meios e recursos através da arte, para transmitir um pensamento atual de modo mais completo, mais claro e universal possível.

Seu meio de expressão não era dirigido aos setores comerciais, não visava lucro, tanto que recusou diversas propostas de industrializar seus motivos, adornos e imagens, voltando-se apenas para a pesquisa, pois seu objetivo íntimo era a pintura. ${ }^{106}$

A citação última de Campofiorito e a de Gonzaga Duque quando da exposição de Visconti em 1901 demonstram que apesar do grande interesse do artista pelas artes

\footnotetext{
${ }^{104}$ Quirino Campofiorito, op. cit., p. 75.

105 Irma Arestizabal, "Eliseu Visconti e a arte decorativa", in Eliseu Visconti e a arte decorativa, op. cit., p. 41.

${ }^{106}$ Leonardo Visconti Cavalleiro, “Desenho \& Industrial”, in idem, p. 14.
} 
aplicadas, a opção pela pintura acabou por prevalecer, muito provavelmente em função do nosso acanhado meio artístico tratar com distinção e méritos os artistas praticantes das belas artes. Mas, mesmo assim Visconti realizou esporadicamente alguns outros estudos e trabalhos de arte decorativa.

No contexto artístico da época, se Visconti tivesse realmente optado pelas consideradas artes menores, como "represália” a Academia acabaria por marginalizá-lo, afastando-o das benesses, prêmios e encomendas, que o autoritário e centralizador sistema acadêmico proporciona aos seus membros. A “renúncia” de Visconti pode ser entendida como uma medida cautelosa frente a um sistema que toma para si a incumbência de gerir a carreira do artista. Dirigir, orientar e reconhecer o artista e a sua obra, são mecanismos de garantia que tornam o artista dependente, fato este agravado pelas poucas oportunidades de trabalho.

Por outro lado, a dedicação a uma arte menor, era tida na época e de certa forma até hoje o é, como impedimento à produção pessoal do artista, o que neste caso pode ser atribuído a dois motivos: primeiro, a questão da tomada do tempo e disponibilidade, segundo, o exercício constante em outras linguagens e materiais acabam afastando o artista de seu campo de experimentação e produção, a exemplo da querela pintor ou cartazista - "o cartazista não pode ser mais do que um pintor de ocasião e o pintor um cartazista por acidente” ${ }^{107}$

Finalmente, tendo em conta os valores servil e mercantil que envolvem a arte menor e que sustentam o preconceito que lhe dirige a arte maior, indagamos o quanto a arte pura é realmente uma arte desinteressada e livre, mesmo que distante de preocupações materiais? As pinturas acadêmicas, sobretudo as históricas, não colocam a arte a serviço de uma propaganda estatal? E a encomenda de retratos não obriga o artista a fazer concessões para corresponder ao gosto de seu encomendante como também a verossimilhança com o retratado? E a arte ela mesma, tal qual a propaganda, também não comunica uma mensagem?

Tudo levaria a crer que nos idos do modernismo a situação poderia ter assumido outros contornos. No entanto, Paim Vieira foi considerado pelo grupo dos modernistas

\footnotetext{
${ }^{107}$ Esta discussão encobre os conflitos vivenciados entre as belas artes e a publicidade. Sobre o assunto consultar Alain Weill, "Peintres ou affichistes" , in Centre Georges Pompidou, Art \& Pub: art et publicité 1890-1990, Paris: Éditions du Centre Georges Pompidou, 1990, pp. 100111.
} 
um "desenhista comercial”, devido aos seus trabalhos decorativos comerciais, como monogramas, marcas, cartazes e propaganda. ${ }^{108}$

Dois casos se configuram, Visconti e Paim Vieira, o primeiro que não envolveu sua arte com os setores comerciais como gostaria talvez de tê-lo feito, pois aparentemente "não visava lucro" e as artes decorativas lhe eram propriamente um terreno de investigação estética, preferindo, assim, se dedicar à arte pura e, o segundo, considerado pelos modernistas um “desenhista comercial”. Diante disso como entender que os dois sistemas artísticos envolvidos, o sistema acadêmico e o moderno, que por naturezas distintas os tornam opositores, segregam seus artistas utilizando-se do mesmo argumento?

Essa ocorrência sinaliza que mesmo dentro de instâncias não oficiais, como é o caso dos modernistas, permanecia o apego aos mesmos valores de êxito do sistema coexistente acadêmico, ou seja, o reconhecimento e a confirmação do talento do artista que findam por lhe proporcionar ganhos financeiros. Esses valores absorvidos pelo sistema artístico moderno impedem que seus agentes aceitem a produção de Paim por seu sucesso não estar naquele momento ligado às belas artes, mas, quase que exclusivamente, às artes menores, tomada de posição que mantém o vínculo com a manutenção das hierarquias artísticas.

A maioria de nossos pintores e escultores não se engajou em profundidade com as linguagens modernas, como ocorreu com os artistas das vanguardas históricas. Essa constatação nos permite afirmar que os artistas brasileiros não conseguiram ou não souberam fazer das artes aplicadas, o que inclui a publicidade, um mote para questionar as hierarquias artísticas. Basta recuperarmos os estímulos que a "flor da vida contemporânea” imprimiu nos poetas e/ou artistas plásticos internacionais, ${ }^{109}$ não

108 Ver Ruth Sprung Tarasantchi, "Paim um artista nacionalista”, Revista do Instituto de Estudos Brasileiros, São Paulo, (29): 103, 1988.

${ }^{109}$ Citamos alguns nomes de artistas plásticos que trabalharam diretamente para a publicidade: René Magritte, Edward Hopper, Salvador Dali, Fortunato Depero e Kurt Schwitters. Analisando essa cooperação por outro viés temos, no século XX, os artistas vinculados aos programas estéticos das vanguardas históricas que também deram sua contribuição à propaganda, a exemplo dos cubistas Robert e Sonia Delaunay, dos futuristas de primeira geração Umberto Boccioni que se dedicou no início de sua carreira à gráfica publicitária, bem como Giacomo Balla, e dos de segunda geração como Fortunato Depero, que em 1931 lançou o manifesto "Il futurismo e l'arte pubblicitaria”, Ivo Pannaggi, Bruno Munari, Ugo Pozzo, e do construtivismo russo El Lissitsky e Alexandr Rodchenko. Por outro lado, é possível encontrar na produção de alguns artistas vanguardistas contaminações da linguagem publicitária ou da publicidade mesmo enquanto materialidade, a exemplo de Pablo Picasso, Georges Braque, Juan Gris, Gino Severini, Marcel Duchamp, Francis Picabia, Raoul Hausmann, Kurt Schwitters, Theo van Doesburg, René Magritte, entre outros. 
somente como formas ou novos temas a serem explorados, mas como procedimentos e estratégias que lhe possibilitaram mudanças poéticas.

Decorrente desse fato, no período modernista (até pelo menos os anos 40) vigorava significativamente na arte brasileira a preponderância das artes puras sobre as artes aplicadas, alimentando um sistema binário excludente - arte maior/arte menor, arte/não arte, belo/não belo, comercial/não comercial - verificável não só nas instituições oficiais de ensino, como também em seus aparatos modernos, como os críticos e os marchands. Se, não podemos excluir dessa lógica dual o próprio artista, pois a mola propulsora dessa disposição é a visão romântica que desde o século XIX ele nutre de si e da arte, tampouco podemos desprezar o público que tem seus juízos de valores sedimentados também em dispositivos românticos, ou seja, na imagem do artista marginal, genial e sofrido que não cede seu talento ao gosto burguês, portanto não há identificação com o artista que trabalha para o mercado, que comercializa seu talento e se enriquece e sim com aquele que se dedica à arte livre.

A visão romântica se "institucionalizou”, promoveu uma auto-elitização do artista e este elevou sua obra ao patamar de uma "exclusiva propriedade intelectual”. Acreditando em sua vocação e na sua predestinação o artista passou a dispensar uma educação profissional formal e a negar que as atividades artísticas possam fazer parte da divisão técnica do trabalho, essas ocorrências implicam um acento devocional às artes maiores em detrimento das artes aplicadas. ${ }^{110}$

Dificilmente um artista que crê na sua vocação artística e que perpetua valores da escola romântica, individualistas e de expressão autobiográfica, que tem sua arte como obra única, original e irreprodutível, portadora de verdades sagradas e inspiradas, aceitará participar do circuito das artes menores, no qual deverá abrir mão muitas vezes, a exemplo dos anúncios publicitários, da sua autoria e mesmo de sua obra, sem contar com as interferências e exigências dos clientes anunciantes. Esclarecedores desta situação são os comentários que Gilles Lipovetsky tece acerca das diferenças entre a arte e a publicidade, sendo que esta tem

um objetivo de venda e de eficácia imediata que, evidentemente a arte não tem, a qual é guiada por uma busca não de mercado, mas autônoma, "livre". É por isso que a obra de arte se apresenta como uma assinatura, um estilo reconhecível. O anúncio publicitário é anônimo e de início está a serviço do produto. A arte é um objetivo em si, a publicidade não é

\footnotetext{
${ }^{110}$ Juan Acha, Introducción a la teoria de los diseños, México: Editorial Trillas, 1988, p. 70.
} 
mais do que um meio de comunicação entre o produto e o público. Enquanto que a arte é aberta, de difícil acesso, polissêmica, a publicidade é simples, unívoca. As condições de produção são incomparáveis: o artista é o único responsável por sua obra, o creatif deve traduzir o mais possível o pedido do anunciante. ${ }^{111}$

As questões que tratam da arte a serviço do povo, mais especificamente do papel da arte na propaganda veiculado na revista base, dificilmente encontrariam a repercussão esperada, pois nossos artistas mantiveram-se apegados ao individualismo estético não desejando ver-se submetidos às regras de criação, tais como demanda à propaganda comercial, o que pode ter contribuído para reduzir a participação dos artistas plásticos, principalmente os pintores de primeira linha, na publicidade brasileira, pois se estabelecermos uma comparação com os desenhistas do lápis, a contribuição destes é mais significativa pelo menos até os anos 30.

Se para o artista plástico os levantamentos teóricos aqui tratados lhe tocam mais de perto, os artistas do lápis de modo geral se comportam com mais flexibilidade no mercado de trabalho, pelo fato de suas contribuições à publicidade comercial guardarem proximidade com os desenhos, ilustrações e caricaturas que eles realizavam na imprensa periódica. Como bem sabemos o desenho além de ser uma forma de expressão autônoma, sempre esteve vinculado ao espaço profissional sendo subjugado tecnicamente a outras atividades criadoras. Por outro viés, os desenhistas, ilustradores e caricaturistas formaram grupos de profissionais independentes das consagradas instituições artísticas e estavam muito mais próximos do público e do seu gosto e da produção de uma arte “útil”, do que os pintores, que se dedicavam à criação da arte pela arte.

\footnotetext{
${ }^{111}$ Françoise Serre; Philippe Arbaizar, "Art et publicité: vers l' accessoirisation de la vie?
} Entretien avec Gilles Lipovetsky”, in Centre Georges Pompidou, op. cit., p. 508. 


\subsection{CONTRIBUIÇÃO DOS DIVERSOS PROFISSIONAIS DAS ARTES PLÁSTICAS NA PUBLICIDADE COMERCIAL BRASILEIRA}

\subsubsection{DAS PASSAGENS DOS ARTISTAS PLÁSTICOS}

Le peintre qui veut la liberté de l'esprit est en butte à l'hostilité générale, le peintre officiel est un grand personnage, le peintre industriel est un salarié à qui l'on s’adresse pour décorer les bordels, les églises, les étalages des grands magasins, les affiches de publicité et les autres moyens de propagande moderne. ${ }^{112}$

René Magritte

Na década de 1920, ao compararmos as colaborações na publicidade brasileira dos artistas plásticos com os caricaturistas e os ilustradores, confirma-se no âmbito das autorias reconhecidas que essas duas últimas classes profissionais eram as mais requisitadas e aquelas que mais produziam, muito provavelmente, conforme já vínhamos comentando, em função de fazerem parte do sistema empresarial dos jornais e revistas que apostavam na diversidade de atividades. Porém, a participação do artista plástico na propaganda comercial brasileira não passa em branco e pode ser sentida nos estudos não datados de Henrique Bernardelli para os projetos Companhia de Fiação e Tecidos Confiança Industrial Vila Isabel e Cia. Progresso Industrial de Bangú, entre outros, ${ }^{113}$ no anúncio Restaurant Madrid de Belmiro de Almeida ${ }^{114}$ e no já citado cartaz

${ }^{112}$ Apud Georges Roque, Ceci n’est pas um Magritte: essai sur Magritte et la publicité, Paris: Flammarion, 1983, p. 151. A tradução do trecho corresponde: "O pintor que deseja a liberdade de espírito é alvo de hostilidade geral, o pintor oficial é um grande personagem, o pintor industrial é um assalariado a quem se dirigem para decorar os bordéis, as igrejas, a disposição de mercadorias dos grandes magazines, os cartazes de publicidade e os outros meios de propaganda moderna”.

${ }^{113}$ Ver Pinacoteca do Estado, Catálogo Geral de Obras, São Paulo: Secretaria do Estado da Cultura: minC: IMESP: DEMA: Pinacoteca do Estado, 1988, pp. 147-148 e 185.

${ }^{114}$ Belmiro de Almeida, Julião Machado, Bambino, Raul e K. Lixto foram colaboradores do jornal de propaganda comercial O Mercúrio (1898). Informação citada em 100 anos de propaganda, São Paulo: Abril Cultural, 1980, p. 3 e em Roberto Simões, op. cit., p. 58. E, 
de propaganda da COMP ${ }^{\mathrm{IA}}$ ANTARCTICA [FIG. 29] de Eliseu Visconti. ${ }^{115}$ Nos anos finais dessa década, Di Cavalcanti, artista bastante atuante e influente não só nos meios artísticos, mas também no da imprensa escrita, produziu em 1928 um anúncio para o dentifrício OdOL [FIG. 41, 1928] que naqueles anos foi um diferencial dentre outros elaborados no Brasil; e, por final, encontramos referências que entre os anos de 1929 a 1930 Quirino Campofiorito trabalhou como desenhista publicitário para a Metro Goldwyn-Mayer, e desse período é o seu cartaz do filme OuRo [FIG. 56, 1929].

Fulvio Pennacchi, de 1929 a 1932, mobilizado por necessidade financeira, muito provavelmente tal qual Lívio Abramo e Danilo Di Prete, ${ }^{116}$ produziu vários pequenos projetos de cartazes comerciais alguns para empresas reais e outros para fictícias [FIGS. 61-107, 214, 215, 216]. ${ }^{117}$ Segundo consta do diário de Pennacchi, em meados de janeiro de 1932, ele e o escultor Antelo Del Debbio montaram um ateliê de reclames. Em 7 de março desse mesmo ano, o artista comentaria que

o ateliê Clamor não rendeu mais nada. Realizei muitíssimos projetos, nesses últimos dias, até dois desenhos para uma casa de moda, mas a dona, ao ouvir o preço de 120 mil réis, só faltou bater na gente. Continuo desenhando, mas só para me exercitar.

foram esses mesmos caricaturistas, os responsáveis pelos primeiros anúncios ilustrados, em 1875, publicados em Mequetrefe e O Mosquito.

${ }^{115}$ Cartaz exposto na exposição Aquarela brasileira, Rio de Janeiro: Centro Cultural Light, 22 maio - 15 jul. 2001, p. 8.

${ }^{116}$ Em 1930, Lívio Abramo teria realizado desenhos de modas, cartazes de propaganda, além de pintar anúncios, cortinas de teatro e de cinema. Consultar a Enciclopédia de Artes Visuais do site www.itaucultural.org.br. E, por volta de 1948-1950, trabalhou três ou quatro meses na Empresa Interamericana de Publicidade como desenhista-chefe. Ver Frederico Morais, op. cit., p. 211. Sobre Danilo Di Prete retomar a citação da página 50, nota 59, que consta do item 2.2 ESTUDO DE CASO: REVISTA DO GLOBO deste capítulo.

117 Entre 1929 e 1935, Pennacchi para ganhar dinheiro realizou vários trabalhos decorativos como pinturas de almofadas, de frisos e vasos, e também desenhos para bordados. Cf. Mariarosaria Fabris (trad.), "Diário de Fulvio Pennacchi”, in Pennacchi 100 anos, São Paulo: Pinacoteca do Estado de São Paulo, maio - jun. 2006, pp. 108-110, 112 e 115. Sobre os trabalhos desenvolvidos na área das artes aplicadas têxteis, Ana Paula Cavalcanti Simioni, ao tratar da artista Regina Gomide Graz, comenta que devemos relativizar este tipo de envolvimento artístico para suprir necessidades financeiras, pois no mercado brasileiro do período não existiam artista-decoradores qualificados. E, segundo a autora "pode-se mesmo supor que não foi a ausência de demanda que criou novos tipos de oferta, mas bem ao contrário, que a oferta trouxe novas e desconhecidas demandas.” Consultar Ana Paula Cavalcanti Simioni, Das belas-artes às artes aplicadas: a experiência suíça de Regina Gomide Graz (1913-1920), São Paulo: XXVI Colóquio do Comitê Brasileiro de História da Arte, 2006, p. 2. Acrescentaríamos a essa discussão, como um terceiro fator que impeliria ao sucesso dessas investidas, o circuito social em que o artista se insere e circula no momento mesmo de sua produção, pois a nosso entender o de Pennacchi, nos primeiros anos de sua permanência no Brasil e o Regina Gomide Graz são bastante díspares. 
E em 27 abril de 1932, ainda menciona ter realizado um cartaz publicitário para o medicamento APOGASTRINA por 250 mil réis e outros projetos para cartazes. ${ }^{118}$

Complementando as informações anteriores, sabemos que Pennacchi em outubro de 1929 executou estudos decorativos para trabalhos comerciais, ${ }^{119}$ em novembro realizou "exercícios de cartazetes publicitários com o objetivo de encontrar trabalho junto ao decorador Martinelli”, de junho a agosto de 1930 estudou "reclames com poesia”, ${ }^{120}$ produziu "alguns reclames de péssimo gosto e em péssimas condições para um amigo de Lucca, Sartini” e também “outro desenho por 50 mil réis para Remedi (barco a motor)” e em 1931, com Antelo, participou de um concurso de cartazes publicitários para os “Leprosos”. 121

Se as dificuldades financeiras vivenciadas por Di Prete nos anos iniciais de sua imigração (final da década de 1940) foram supridas pela produção de anúncios e cartazes publicitários e outros trabalhos considerados decorativos, as razões do seu contínuo exercício estão afins com as de um outro pintor, Aldo Bonadei, que por meio dos conselhos de seu pai - "Não queira ser pintor. Pintura, não dá roupa e nem comida a ninguém” - vivifica a necessidade do aprendizado de um ofício para o sustento próprio, o que por sua vez liberta o artista de uma submissão artística. Assim é que Bonadei, como desenhista de modas pôde afirmar: "Minha vida tem sido uma continua reação à dependência da pintura, como base de subsistência”. ${ }^{122}$ Deduzimos que conjugar dinheiro com a arte pura é conflitante para os artistas plásticos impondo-lhes, para suas

\footnotetext{
${ }^{118}$ Idem, pp. 114-115. Clamor nunca chegou a existir, conforme pesquisa por nós realizada na Junta Comercial do Estado de São Paulo.

${ }^{119}$ Desconhecemos a natureza desses trabalhos. Ao contrário do que julgávamos o desenhista publicitário, não necessariamente criava os anúncios sob encomenda de algum cliente, como nos esclarece a citação localizada em Cia. dos Anúncios em Bondes - em alguma parte (March 26, 2002, p.2): "Uma coisa engraçada, vocês sabem que primeiro eles faziam um rought, e o corretor saia vendendo para quem foi feito sem pedido prévio do cliente, e o corretor corresponderia mais ou menos o que seria o atendimento hoje em dia”. Disponível em http://katia.cabaretvoltaire.com/blog/archives/2002_03.html (2 of 18).

${ }^{120}$ Entre 22 de maio a 10 de junho, Pennacchi escreveu em seu diário: "Recebo, no último dia do mês passado, dez números da [revista] Fiera Letteraria. E, em seguida emendaria o comentário “Atualmente, estou estudando reclames com poesias". Consultar Mariarosaria Fabris (trad.), op. cit., pp. 112. Estes comentários demonstram que Pennacchi estava atualizado e mantinha contato com as publicações italianas. Lembramos que, somente em 1933, o poeta Giovanni Gerbino escreveu o manifesto, no qual ele lança a teoria de uma "poesia publicitária”. ${ }^{121}$ Idem, pp. 109, 112 e 114. Os artistas participaram com quatro cartazes, mas não foram contemplados.

${ }^{122}$ Hideo Onaga, “O pintor sustentado pelo desenhista de modas”, s.l, s.d. Recorte de jornal localizado na Divisão de Pesquisa do Arquivo Multimeios da SMC-PMSP do Centro Cultural São Paulo.
} 
sobrevivências materiais, escolhas de outras naturezas não pertencentes ao campo da produção pura, e sim, muitas vezes, aquelas alojadas na esfera do campo artístico comercializável, a exemplo da publicidade e das artes decorativas.

Esse posicionamento por parte dos artistas, exclui a possibilidade da arte menor, aquela comercializável, interferir, ou melhor, permitir empréstimos visuais e plásticos às suas produções pessoais, ou mesmo funcionarem como possíveis suportes para as suas linguagens poéticas. Assim, os comentários de Di Prete e Bonadei ao encobrirem o credo na arte maior desvinculada das artes menores, enfatizam a supremacia das belas artes, de modo a não se cogitar e tampouco reconhecer as trocas possíveis entre as produções da arte maior e menor, por tê-las como dois campos de produções artísticas separados e descontínuos, e com objetivos distintos, um, o da criação "livre” e o outro, da criação comprometida com a encomenda e com o suporte financeiro. Aparentemente, nem mesmo fazer concessões dentro da arte pura era aceitável, o que nas artes aplicadas poderia ser praticável, como de certo modo declarou Pennacchi: “detestava adaptar a minha arte a qualquer ambiente. Preferia viver humildemente de outra atividade que submeter a minha sensibilidade aos gostos burgueses”. ${ }^{123}$

Nos anos 30 o artista plástico começa a estender seus interesses à propaganda e já é possível localizarmos mais informações dos enleios dessas duas atividades. Neste contexto a revista base: arte, técnica e pensamento em seu número de outubro de $1933^{124}$ alinhada aos ideais da época, incorpora, apoiando-se na propaganda, o desejo da arte exercer uma função social ou então como sugere o seu subtítulo, arte e técnicas modernas a serviço da sociedade informando sobre os progressos da ciência, da indústria, do comércio entre outros. Contudo, o pano de fundo nos parece ser a acessibilidade a esse campo de atividades o qual se edifica com mais oportunidades de trabalho devido à atuação das agências de propaganda norte-americanas nas cidades de São Paulo e no Rio de Janeiro. Mas, em verdade, a revista não faz referência aos artistas plásticos, ao contrário seus exemplos de anúncios e cartazes advêm somente do outro pólo, o dos desenhistas publicitários estrangeiros que se fixaram no Brasil, entre eles: Americo Rosenberg (erico), Gerhard Orthof, Franz Kohout, Hans Reyersbach, nomes

${ }^{123}$ Cf. Carta manuscrita de Pennacchi, s.l., s.d. Documento localizado junto à Biblioteca e Centro de Documentação do MASP. O texto original apresenta-se: "L'arrivo in Brasile 5 luglio 1929, fu per me duro difficilissimo, per natura detestavo adattare la mia arte a qualsiasi ambiente. Preferivo vivere umilmente di altra attività che sottomettere la mia sensibilità a gusti borghesi [...].

${ }^{124}$ Consultar o artigo de A. Xavier da Silva, op. cit., incluindo as páginas 54 a 61 que apresentam trabalhos publicitários dos profissionais mencionados. 
que se destacam em várias campanhas publicitárias do período e que geralmente trazem consigo o aprendizado em artes gráficas em outros centros internacionais. De modo não tão explícito o que se configura neste caso é uma reivindicação não só do espaço do profissional das artes publicitárias, mas também o reconhecimento e a valorização de seus trabalhos dentro do campo das artes maiores.

Nota-se também nesta década um interesse crescente pelo cartaz. A Pro-Arte (Sociedade de Artistas e Amigos de Belas Artes - RJ) e o Club dos Artistas Modernos SP promoveriam algumas exposições de cartazes no ano de 1933. E, neste mesmo ano, J. L., comentando sobre a Feira de Amostras do então Distrito Federal, aponta para o que considerou uma falha da comissão organizadora do evento - a ausência de cartaz ou mesmo a promoção de um concurso de cartazes para promover a feira ${ }^{125}$ o que faz deduzir que o cartaz era visto como um meio eficiente de propaganda. Complementando esse quadro de valorização do cartaz, observa-se que em dezembro de 1932, a revista $\mathbf{O}$ Malho veiculou uma nota informando sobre a exposição de cartazes da Loteria Federal que ocorreu no LAO/RJ e contou com a participação de cerca de 160 artistas. ${ }^{126} \mathrm{E}$, em 1936 Tarsila do Amaral publica um artigo no qual, afora se revelar conhecedora da linguagem moderna e das exigências técnicas e criativas que asseguram a eficácia do cartaz, constata que no Brasil

os cartazes ainda andam adormecidos. Sem o senso da estética, sem o sentido da cor, do movimento, da síntese, do interesse, formam, com raríssimas exceções, uma paisagem amorfa de papéis pintados, por onde passeia distraidamente o olhar vadio. ${ }^{127}$

$\mathrm{Na}$ década seguinte muitos foram os concursos promovidos por órgãos governamentais para a criação de cartazes não comerciais, a exemplo da Campanha do Censo (1940), Campanha Contra a Quinta Coluna (1942), Jornada de Reservista (1943), o das Américas Unidas (1942). Vários artistas se dedicaram ao cartaz como o pintor suíço Jean Pierre Chabloz $^{128}$ que em 1943 foi convidado a fazer publicidade da

125 J. L., "a feira de amostras", base: revista de arte, técnica e pensamento, Rio de Janeiro, (3): 69, out. 1933.

${ }^{126}$ Ver O Malho, Rio de Janeiro, 10 dez. 1932, s.p.

127 Trata-se do artigo “Os cartazes”, apud Aracy Amaral, Tarsila cronista, São Paulo: Editora da Universidade de São Paulo, 2001, pp. 95-96.

128 Jean Pierre Chabloz (1910-1984) chegou ao Brasil em 1940 com experiência em artes gráficas e decoração adquiridas na Escola de Belas Artes de Genebra. Residindo no bairro carioca de Santa Teresa teve contato com os artistas Emeric Marcier, Arpad Szenes, Maria Helena Vieira da Silva e Tadashi Kaminagai. A partir de 1943 se transfere para a cidade de 
Campanha da Borracha e depois foi contratado para chefiar o Serviço de Desenho do Serviço Especial de Mobilização de Trabalhadores para a Amazônia (SEMTA); Portinari, em 1942, realizou alguns projetos para cartazes também não comerciais COMBATE AO INIMIgO, duas versões de PlANTE PELA VITÓRIA e GuERRA e algumas ilustrações para cartazes, dentre elas ATAQUE AÉREO, CUIDADO!, EXTINÇÃO DE BOMBA INCENDIÁRIA.

Apesar dessas incursões na cartazística, em 1951, por ocasião do 1 . $^{0}$ Salão de Propaganda, no Masp, a revista Habitat afirmaria que "a arte do cartaz no Brasil não está muito desenvolvida”. O articulista reconhece que “o comitente precisa tornar-se mais experimentado. Lembramos planos para campanhas não realizadas, porque 'não aprovadas' pelos industriais e comerciantes pelos quais foram projetadas”. ${ }^{129}$

Se buscarmos as raízes que envolvem as associações entre cartaz, arte social e propaganda, constatamos que essa problemática é importada, sobretudo do cenário da arte moderna francesa dos anos finais da década de 20, e que possibilitou dois encaminhamentos para a cartazística. ${ }^{130} \mathrm{O}$ primeiro deles, de certo modo já comentado, vê na arte publicitária do cartaz, na arte da rua, uma possibilidade de ruptura com uma prática solitária da arte e, portanto com o romantismo estético, o que elevaria a arte ao verdadeiramente social, uma arte compreensível e direcionada a todos e não a um restrito circuito de pessoas. O segundo, deposita na publicidade não só a educação artística das massas, mas também a possibilidade de nela o artista plástico/cartazista trabalhar para qualitativamente corresponder às exigências estéticas do público, proporcionando melhorias no nível da arte publicitária. Essas orientações dialogam com dois sistemas artísticos: primeiro, com o Art Nouveau, enquanto este não fôra um estilo institucionalizado pelas belas artes, ou seja, quando ainda não havia se voltado exclusivamente para uma estética da ornamentação e para o produto decorativo artesanal de luxo, características que distanciam o movimento francês dos seus objetivos iniciais (eliminar a distinção entre arte maior e arte menor e aproximar arte e técnica); um segundo, que se configura após a I Guerra Mundial, por meio dos partidários da arte

Fortaleza incentivando a vida artística local. Dos anos 30, portanto do período anterior a sua estadia no Brasil, são seus cartazes publicitários para SCHAEFER, IL FIOR DELLA SALUTE,

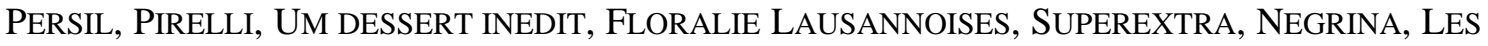
PHARES LUCIDUS. Sobre essa sua produção publicitária consultar o catálogo Jean Pierre Chabloz 1910-1984: pinturas e desenhos, Fortaleza: Galeria Multiarte, 7 maio - 27 jun. 2003, pp. 44-49.

${ }^{129}$ Habitat, São Paulo, (2): 44, jan. - mar. 1951.

${ }^{130}$ No cenário artístico publicitário francês, a Union des Artistes Modernes - U.A.M. (1929), cisão da Société des Artistes Décorateurs, foi a responsável por essas discussões. 
moderna, defensores da sociedade de consumo e de uma estética influenciada pela forma dos objetos industriais.

No Brasil, Mário de Andrade, em sua crônica O culto das estátuas (1929), resvala nas questões - educação das massas, cartaz comercial como suporte para os discursos da modernidade, arte da rua - ao abordar os monumentos públicos:

Só vejo um jeito do monumento ser educativo: é pela grandiosidade obstruente e incomodatícia. O monumento, pra chamar a atenção de verdade, o monumento que obriga a gente a parar, não pode fazer parte da rua. O monumento tem que atrapalhar. Uma dona em tualete de baile é muito mais monumental na rua Quinze, mesmo sendo catatauzinha, do que o monumento a Olavo Bilac ou a própria escadaria de Carlos Gomes. A gente pára e pensa "quem será". Isso os comerciantes perceberam muito bem, principalmente depois da chegada dos Estados Unidos e da eletricidade. É incontestável que o anúncio erguido à memória dos cigarros Castelões ou do automóvel Marmon no Anhangabaú são monumentos como jamais Carlos Gomes ou Olavo Bilac não tiveram. ${ }^{131}$

Conjeturamos a impossibilidade de transferir esses encaminhamentos para o Brasil, pois, como afirmamos em vários momentos desse estudo, nossa produção de cartazes e o nosso envolvimento com as artes aplicadas foram acanhados.

Teremos que esperar até a década de 50 com a progressiva constituição do profissional do design brasileiro, seja ele o designer industrial ou o programador visual, para que os artistas gráficos e ilustradores comerciais e mesmo os artistas plásticos revejam ou mesmo ultrapassem os posicionamentos dualistas e conflitantes que encerram seus trabalhos publicitários tão somente na atividade artística ou na comercial, pois de agora em diante essas suas produções passam a ser consideradas como o resultado de um metiê técnico e racional, um metiê de parcerias, de entrecruzamentos e hierarquias profissionais.

À parte dessa discussão, nesses anos podemos citar a produção de anúncios comerciais dos mineiros Del Pino para o sabonete ARAXÁ [FIG. 58, 1936] e Monsã para a LOTERIA DO ESTADO DE MINAS GERAIS [FIG. 57, 1939], ${ }^{132}$ respectivamente em 1936 e 1939, e do arquiteto Maurice Nozières que em 1932 realizou para a fábrica de móveis

\footnotetext{
${ }^{131}$ Telê Porto Ancona Lopez, Mário de Andrade, táxi e crônicas no Diário Nacional, São Paulo: Duas Cidades: Secretaria da Cultura, Ciência e Tecnologia, 1976, p. 148.

132 O prof. Aníbal Matos ao comentar sobre as impressões "da paupérrima secção de cartazes” do III Salão de Bellas Artes de Belo Horizonte menciona a colocação de Monsã, primeiro prêmio com "Loteria" afirmando ser um magnífico desenhista no gênero. Consultar Bellas Artes: Jornal dos Artistas Plásticos, Rio de Janeiro, (53-54): 3-4, out. 1939.
} 
LAUBISCH-HIRTH um anúncio interessante pelo emprego de um código visual moderno [FIG. 54, s.d.].

Especialmente na década de 40 vislumbramos um comprometimento declarado e mais intenso dos artistas plásticos com a publicidade e que pode ser agrupado em dois núcleos, o primeiro que corresponde ao “movimento” dos gravadores e ilustradores atuantes no Rio de Janeiro que agora parecem entrever com mais clareza uma possível relação das atividades gráficas que envolvem a publicidade e o campo editorial, e um segundo que advém do trabalho direto dos artistas nas agências de propaganda, a exemplo de Hermelindo Fiaminghi.

No primeiro caso tem-se o artista Santa Rosa testemunhando o frutificar da relação artes plásticas-propaganda quando em 1946 é nomeado professor do Curso de Desenho de Propaganda e Artes Gráficas da Fundação Getúlio Vargas*, "uma velha idéia do artista, desde os tempos em que Portinari dirigiu o Curso de Pintura da Universidade do Distrito Federal e o convidara precisamente para ministrar a parte de Desenho de Propaganda. Mas a Universidade foi fechada”. ${ }^{133}$ Segundo o seu folheto de divulgação, o curso destinava-se a

profissionais em atividade em empresas gráficas particulares e em institutos oficiais ou paraestatais que mantêm serviços nesse ramo do desenho técnico. Nele se permitirá ainda ingresso a estudantes de desenho e pintura cujo nível de conhecimento se revele satisfatório, à vista de provas vestibulares.

Além disso,

visava dar a conhecedores do desenho básico, o domínio seguro do desenho de propaganda e artes gráficas, especialização que, dia a dia, se torna mais necessária, em face do avanço da técnica de publicidade e da expansão que, mesmo no nosso meio, estão tendo os livros, as revistas e os jornais. ${ }^{134}$

133 “Santa Rosa Professor de Desenho de Propaganda”, Publicidade: Revista de Propaganda e Negócios, Rio de Janeiro, (61): 6, maio 1946.

${ }^{134}$ Apud Frederico Morais, op. cit., p. 194. 


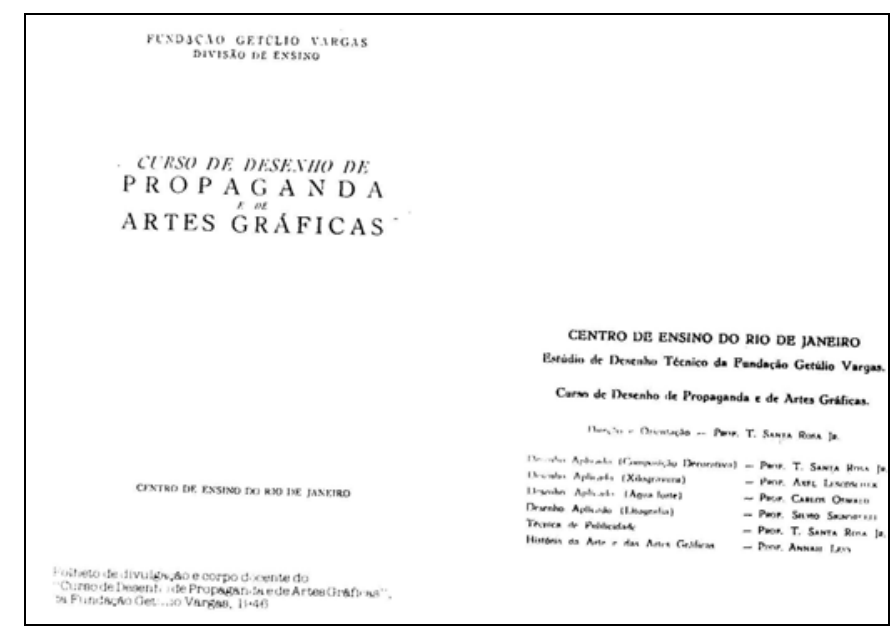

*Axl Leskoscheck e seus alunos Brasil / 1940-1948. Rio de Janeiro: Museu de Arte Moderna do Rio de Janeiro, s.d.

Considerado o primeiro curso livre em artes gráficas, foi previsto para durar seis meses, com três áreas disciplinares: desenho aplicado às artes gráficas, elementos de história da arte e das artes gráficas e técnica de publicidade. Dentre seus professores figuram o austríaco Axl Leskoschek, Carlos Oswald e Hannah Levy que respectivamente ensinavam xilogravura, água-forte e história da arte. A direção e orientação ficaram a cargo de Santa Rosa que se ocupava também das aulas de composição decorativa e técnica de publicidade.

Em relação ao "desenho aplicado às artes gráficas", Frederico Morais nos informa que dentre os tópicos ensinados estavam, entre outros: “conceito do desenho, forma, linha, arabesco, espaço, relações entre natureza, arte e realidade, figura humana, composição, instrumentos de trabalho, modos de impressão, ilustração (livro, revista, caricatura, prosa e poesia), tipografia, alfabeto”. 135

Para o crítico Mário Pedrosa o campo de ensino do curso é o das artes decorativas, isto é, “da arte com um fim utilitário, prático, bem definido”. Como resultado dessa iniciativa, diz “poderemos ter uma geração de gravadores autênticos que antes de pensar em fabulosas criações artísticas, terão a alegria modesta de um metier, serão bons artesãos antes de ser artistas”. Já para Michel Kamenha “A escola de Botafogo tem mais uma vantagem: a sua despretensiosidade. Assemelha-se de um certo

${ }^{135}$ Idem, pp. 194-195. 
modo a uma oficina medieval ou do tempo da Renascença, quando o metier e a arte se confundiam, eram uma só coisa”. ${ }^{136}$

Apesar de essa iniciativa endereçar-se igualmente ao desenho publicitário, verificamos que o curso acabou por priorizar o resgate da gravura, ${ }^{137}$ primeiramente por equipará-la em importância às outras artes, e em segundo lugar como uma tentativa de sua prática ser inserida no mercado de trabalho, mais especificamente no campo da indústria do livro ou do jornalismo, pois para Santa Rosa o desenho a nanquim oferecia poucos recursos ao desenhista. Sem contar que ele era um defensor da ponta-seca, da água-forte e da água-tinta como também da xilogravura e da litogravura, que considerava técnicas não praticadas e tampouco estimuladas. ${ }^{138}$ Assim não é por acaso que Carlos Oswald fazia parte do corpo docente, pois realizou um trabalho pioneiro não só no ensino como também na divulgação das técnicas tradicionais da gravura em metal no Rio de Janeiro. Essa nossa hipótese pode ser confirmada pelo fato deste curso ter iniciado uma geração de gravadores, a exemplo de Fayga Ostrower, Renina Katz, Ramiro Martins, Danúbio Gonçalves, Bartolomeu de Andrade, Anísio Medeiros, entre outros. Finalmente, confirma-se que as aulas de desenho de propaganda não foram adiante, pois o

material encontrado nos arquivos da Fundação sobre o mesmo restringese unicamente ao folheto de lançamento, já comentado, e a duas páginas datilografadas, provavelmente dirigidas à diretoria, como relatório. Nelas se informa que "durante o período de maio-novembro de 1946, deixou de funcionar a seção de gravura em pedra (a cargo de Sílvio Signorelli), à falta de aparelhagem, bem como a de desenho de propaganda, em face do nível técnico dos alunos”. Ao mesmo tempo se pedia a criação de uma pequena oficina tipográfica. ${ }^{139}$

Retomando o segundo grupo, aquele em que os artistas plásticos efetivamente trabalhavam para as agências de propaganda, temos informações que Walter Levy (anos

\footnotetext{
${ }^{136}$ Apud Axl Leskoscheck e seus alunos Brasil / 1940-1948, Rio de Janeiro: Museu de Arte Moderna do Rio de Janeiro, s.d., s.p. Originalmente, as citações se referem ao artigo de Mário Pedrosa, "Curso de desenho e artes gráficas”, Correio da Manhã, Rio de Janeiro, 15 fev. 1947 e ao de Michel Kamenha, "A propósito de uma exposição", Jornal do Commercio, Rio de Janeiro, 18 mar. 1947.

${ }^{137}$ A gravura durante anos foi considerada uma arte menor pelo seu caráter artesanal, mecânico e multiplicador da obra artística.

${ }^{138}$ Sobre o assunto consultar Cássio Emmanuel Barsante, Santa Rosa em cena, Rio de Janeiro: Instituto Nacional de Artes Cênicas, 1982, pp. 94 e 136-139. Trata-se do texto "Sobre a arte da ilustração", escrito por Santa Rosa.

${ }^{139}$ Ver Axl Leskoscheck e seus alunos Brasil / 1940-1948, op. cit., s.p.
} 
30) estava na Lintas, Livio Abramo, teria sido por um breve tempo desenhista-chefe da Empresa Interamericana de Publicidade (final da déc. 40) e Hermelindo Fiaminghi, um caso particular, pois possui uma vasta experiência nas áreas das artes gráficas como também na publicitária, a exemplo do período em que foi diretor de arte da Lintas International Advertising (1948-1952), produzindo cartazes para a Lever. Suas atividades publicitárias se estenderam aos anos 60, seja como free-lancer, funcionário ou como empresário.

Um exemplo significativo do estreitamento dos caminhos entre a arte e a publicidade, reafirmando a ligação histórica entre elas, uma história repleta de imbricações, facetas e empréstimos pode ser verificado quando Pietro Maria Bardi, possibilitou o nascimento de uma escola de propaganda a partir do espaço mental e físico de um museu de arte, o MASP. 


\subsubsection{DOS ARTISTAS COMO EMPRESÁRIOS}

A criação de peças publicitárias não se limita somente a ser uma atividade que possibilita ganhos extras aos artistas, mas também um modo destes fazerem publicidade de seus empreendimentos comerciais: empresas ou produtos, ou mesmo de suas atividades profissionais. Com este objetivo e, por conseguinte, movidos por interesses próprios ou familiares, encontramos alguns poucos exemplos de artistas plásticos que se dedicaram à produção de cartazes, folhetos, rótulos e anúncios, dentre eles Flávio de Carvalho, Fulvio Pennacchi, Mick Carnicelli e Vicente do Rego Monteiro.

Fulvio Pennacchi concebeu alguns folhetos de divulgação do seu AçOUGUE BoI DE OURO [FIG. 64, 1933]. Os cartazes que Mick Carnicelli criou para a alfaiataria da família não foram localizados e muito provavelmente se perderam, ${ }^{140}$ mas sabemos de suas existências por meio de um artigo de Quirino da Silva:

Na sala, ou melhor, na ante-sala da "Alfaiataria Carnicelli”, alguns cartazes denunciavam que um artista freqüentava aquela casa. Todos anunciavam a última moda masculina, e eram muito bem feitos. Envolvido por uma deliciosa humildade, Mick confessou-me que os cartazes de moda eram de sua autoria, que lhe perdoasse. Tinha de fazêlos a fim de chamar um pouco a freguesia. ${ }^{141}$

No entanto, foi possível localizar dois anúncios, CASA CARNICELLI [FIG. 59, 1920] e Irmãos CARniCelli [FIG. 60, 1921] na revista Papel e Tinta. ${ }^{142}$

Nos anos trinta, Vicente do Rego Monteiro elaborou anúncio para a aguardente GRAVATÁ [FIG. 50, 1936] e rótulo para a CANINHA-CRISTAL [FIG. 51, c. 1933] ${ }^{143}$ do

\footnotetext{
${ }^{140}$ Conversa telefônica com o sobrinho do artista Vicente Augustus Carnicelli, São Paulo, 20 abr. 2001.

${ }^{141}$ Quirino da Silva, “Mick Carnicelli”, Diário de S. Paulo, 2 set. 1962.

${ }^{142}$ Anúncios publicados, respectivamente em Papel e Tinta: Illustração Quinzenal Brazileira, S. Paulo e Rio, (4): s.p., ago. - set. 1920 e (6): s.p., jan. - fev. 1921. Apesar de não estarem assinados, foi confirmada a autoria de Mick Carnicelli, por Vicente Augustus Carnicelli, op. cit. Esta atribuição realmente procede se considerarmos que o artista era o diretor artístico da revista. Finalmente, Yone Soares de Lima comenta que os "anúncios comerciais saíram publicados nas páginas de Papel e Tinta e de A Cigarra. A respeito nos informou Paulo Duarte que, na época, Carnicelli 'fazia desenhos que decoravam as vitrines da alfaiataria de seu pai', à Rua Direita $\left\{\mathrm{n}^{\circ} .1\right.$, sobrado $\}$ conforme constava nos anúncios”. Consultar Yone Soares de Lima, op. cit., p. 191.

${ }^{143}$ Walter Zanini, Vicente do Rego Monteiro: artista e poeta 1899-1970, São Paulo: Empresa das Artes: Marigo Ed., 1997, pp. 32 e 280.
} 
engenho Várzea Grande, interior de Pernambuco. Nestes, observamos que apesar de constar o nome do artista como proprietário das marcas, as peças publicitárias não foram assinadas. E, considerando que o anúncio para a aguardente GravATÁ foi publicado em Fronteiras, 1936, revista que o artista ilustrava e da qual era co-diretor, é interessante observar que somente as suas ilustrações eram assinadas. A ausência de autoria também se verifica nos anúncios para a goiabada Peixe [FIGS. 49, 52], que o artista divulgou nas páginas das revistas Renovação (1939) e Fronteiras (1937).

Flávio de Carvalho apresentou o seu escritório nas páginas do Programa Oficial do Teatro Municipal [FIG. 43, 1930], no livrete da Sociedade Symphonica de São Paulo [FIG. 47, 1930], e nas páginas da revista Rumo [FIG. 48, 1933]. E, ainda elaborou anúncios das cortinas metálicas de sua própria fabricação (1939) [FIG. 45, 1939] e do cartão do estabelecimento comercial A VACA [FIG. 46, 1945], local no qual vendia produtos da Fazenda de Capuava de sua propriedade. ${ }^{144}$ Um cartão pessoal do artista [FIG. 44, s.d.] indicava que o mesmo aceitava encomendas para anúncios.

\footnotetext{
${ }^{144}$ Consultar, respectivamente: Programa Oficial do Teatro Municipal, São Paulo, 29. set. 1930; Sociedade Symphonica de São Paulo, São Paulo, (5): s.p., 28 jun. 1930; e a Seção Indicador Profissional da revista Rumo, Rio de Janeiro, (5, 6): 31, set.- out. 1933; e apud Exposição de Flávio de Carvalho, São Paulo: $17^{\mathrm{a}}$ Bienal de São Paulo, out.- dez. 1983, pp. 66 e 122.
} 


\subsubsection{DOS CARICATURISTAS E ILUSTRADORES QUE MARCARAM ÉPOCA}

Segundo Herman Lima, o anúncio ilustrado pelos caricaturistas proliferou entre os anos de 1900-1950; ${ }^{145}$ no entanto, o autor somente nos fornece exemplos até 1918. Nossa pesquisa verificou que ainda é possível encontrar anúncios comerciais elaborados por caricaturistas até os anos finais da década 40, sobretudo se considerarmos os trabalhos de J. Carlos, mas eles se diferenciam sobremaneira da alentada produção dos vinte primeiros anos do século passado por assumir outros modos de representação distantes do universo crítico da caricatura e do uso das imagens dos políticos.

Como afirmamos em vários momentos deste estudo, a participação dos caricaturistas e ilustradores nas matérias publicitárias teria sido uma via normal e bem aceita em função de seus vínculos com a imprensa escrita e consequentemente também pela comunicação e receptividade do leitor já conquistadas. Cabe observar que a presença desses nas diversas revistas ilustradas era significativa, a exemplo do Departamento de Arte de $\mathbf{O}$ Malho que contava com treze desenhistas. ${ }^{146}$ Por outro lado, nota-se que esses artistas já com uma carreira alicerçada, ao emprestarem suas assinaturas aos produtos anunciados, contribuiriam para a popularização destes, daí uma possível preferência por parte dos anunciantes.

O fato de as autorias dos anúncios serem em sua maioria formalmente expressas nos faz pressupor que os artistas do lápis, mesmo tendo alguns deles uma formação artística tradicional, não pretendiam ser reconhecidos exclusivamente como artistas plásticos que se dedicam à arte maior, pois a caricatura já era um gênero de sucesso mesmo que marginal à arte e ao ensino acadêmico institucionalizados e a ilustração como informação gráfica um meio imprescindível e de crescente valorização. ${ }^{147}$ Assim

\footnotetext{
${ }^{145}$ Herman Lima, op. cit., p. 700.

${ }^{146}$ Dentre eles J. Carlos, Raul, K. Lixto, Crispim do Amaral, Ramos Lobão, Leo, Gil, Seth, Yantok, Storni, Vasco Lima, Alfredo Cândido e Augusto Rocha. Ver Cássio Loredano, O Bonde e a linha: um perfil de J. Carlos, São Paulo: Capivara, 2002, p. 33.

147 Complementando nossas observações, Mônica Pimenta Velloso menciona que "Desde o início do século os caricaturistas começaram a satirizar a posição marginal que alegavam ocupar no universo artístico carioca. Na época, só participavam das exposições da Escola Nacional de Belas-Artes aqueles pintores consagrados pelo mundo oficial da cultura. A partir de 1907, a revista Fon-Fon começou a parodiar as exposições oficiais, [...]. [...]

Por meio desse humor ferino, os intelectuais expressavam seu desacordo quanto aos padrões estéticos da vida cultural. Apropriando-se dos parâmetros artísticos dominantes, parodiavam o
} 
sendo, essas colaborações eram assumidas sem constrangimentos, e tal qual o poeta Bastos Tigre que tinha seu escritório de publicidade, J. Carlos, Francisco Acquarone e Álvaro Marins (Atelier Seth) mantiveram durante anos ateliês de prestação de serviços publicitários. ${ }^{* 148}$ Um outro testemunho desse interesse pode ser verificado na exposição de desenhos para reclames que Umberto Della Latta apresentou em janeiro de 1917 na cidade de São Paulo.

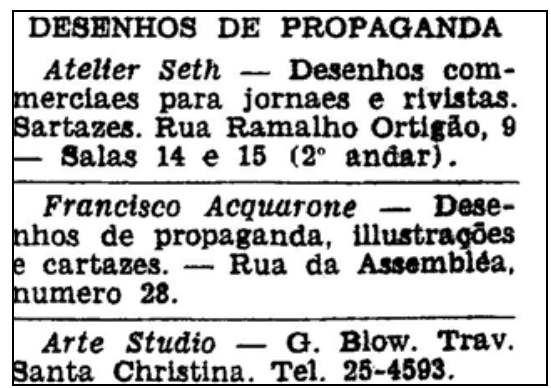

*Bellas Artes, Rio de Janeiro, I, (3): 2, mar. 1935.

Devemos ter em conta que basicamente dois fatores afastaram os caricaturistas e ilustradores da confecção de anúncios comerciais, um deles, que julgamos ser o mais importante, foi o uso crescente da fotografia ${ }^{149}$ que pela sua riqueza de informação e

seu linguajar. Fazendo a crônica humorística das exposições, o grupo já anunciava simbolicamente a idéia de promover o seu próprio salão.

Este projeto viria a se concretizar em 14 de novembro de 1916, dia em que foi inaugurado, no Liceu de Artes e Ofícios, o Salão Nacional dos Humoristas”. Consultar Mônica Pimenta Velloso, Modernismo no Rio de Janeiro: turunas e quixotes, Rio de Janeiro: Editora Fundação Getulio Vargas, 1996, p. 72. Também em 1916, Voltolino expôs e vendeu toda uma série inédita de desenhos aquarelados. Este evento, que ocorreu em duas salas da revista $\mathbf{A}$ Cigarra, é indicativo da aceitação e do reconhecimento público que este gênero artístico dispunha na época.

${ }^{148}$ Na década de 1930 no contexto internacional também foi usual os artistas, sobretudo os gráficos, abrirem seus próprios estúdios de desenho de publicidade, trabalhando de modo independente e diretamente com o cliente. Já o interesse dos nossos artistas do lápis pela propaganda pode ser sentido através da seção "Indicador Profissional” do jornal Bellas Artes, órgão oficial da Sociedade Brasileira de Belas Artes. Este periódico traz, em diversos números, anúncios de alguns ateliês prestadores de serviços à propaganda, bem como de profissionais autônomos. É o caso do Atelier Seth de Álvaro Marins, do Arte Studio de George Blow e de Francisco Acquarone. Consultar Bellas Artes, Rio de Janeiro, I, (3): 2, mar. 1935.

${ }^{149}$ Para o publicitário Fernando Reis, a agência J. Walter Thompson teria sido a responsável, no Brasil, pela introdução da fotografia nos anúncios comerciais. Entretanto, devemos analisar essa afirmação com cautela e sempre levando em conta os processos técnicos que envolvem o seu emprego, pois como já mencionamos a revista A Cigarra explorou significativamente a fotografia em seus reclames desde a década de 1910. Sobre o assunto consultar Fernando Reis, São Paulo e Rio: a longa caminhada, in Renato Castelo Branco et alii, História da propaganda no Brasil, São Paulo: T. A. Queiroz, 1990, p. 311. Nota-se que o advento da fotografia promoveu a extinção do monopólio dos artistas na produção de imagens, principalmente dos 
sedução acabou dominando os espaços dos periódicos; e um segundo, ainda quando o desenho era amplamente utilizado, o fato de a nossa propaganda ter se desenvolvido segundo os métodos e exigências das agências de propaganda norte-americanas que investiam no "bom desenho informativo", ou seja, na ilustração técnica fiel à representação do produto, a qual nem sempre podia ser obtida pelos nossos artistas das revistas e jornais, mais especificamente, os caricaturistas periodistas, pois os mesmos não estavam familiarizados com tal produção.

Do levantamento de material iconográfico observamos não só um mercado centrado no eixo Rio-São Paulo, mas também confirmamos um predomínio na produção de anúncios comerciais dos ilustradores e caricaturistas, se comparado aos artistas plásticos. No período em que esses profissionais atuaram de modo efetivo, destacaramse por um longo tempo caricaturistas como:

- Álvaro Contrim (Alvarus) produzindo para a LIGHT [FIG. 150, 1933];

- Seth com uma quantidade significativa de anúncios, a exemplo do cartãopostal para o produto KRAEMINA [FIG. 160, s.d.], anúncios para o ELIXIR DE Inhame [Fig. 161, 1929], LoÇÃo Phenomeno [Fig. 154, 1939], SABONETE DE BARRY [FIG. 162, 1933];

- J. Carlos com diversas peças comerciais, entre outras, para a Caixa Economia [FIGS. 139, 140, 143, 144] e os CORANTES INDANTHREN [FIG. 141, 1941];

- K.Lixto com seus anúncios para a Loteria Federal [Figs. 176, 177, déc. 40], para os medicamentos Lugolina [FIG. 169, s.d.] e SANAGRYPPE;

- Romano para o xarope Bromil [FIG. 152, 1917] e para a Societé Anonyme du Gaz [FIG. 151, 1936];

- Umberto Della Latta, que em 1935, ainda produzia “reclames” para os chocolates Falchi [FIGS. 163, 167, 168, 210], e para outros produtos como os caramelos Fruna e os perfumes e cosméticos Adoração [FIG. 164, 1936];

desenhistas e gravadores da imprensa, ao mesmo tempo em que promoveu novas técnicas de impressão.

${ }^{150}$ Respectivamente: Programa Oficial do Teatro Municipal, São Paulo, 14 set. 1935; Eu Sei Tudo, Rio de Janeiro, $8^{0}$ do $18^{0}$ (112): 103, jan. 1935; Eu Sei Tudo, Rio de Janeiro, $8^{0}$ do $19^{0}$, (224): 4, jan. 1936. 
- Voltolino com sua produção para o guaraná Espumante e o chocolate Lacta [FIGS. 145, 146, 147] e para a CASA MiCHEL [FIG. 148, s.d.].

Dentre os ilustradores mais conhecidos elencamos:

- Correia Dias que assinou o anúncio da casa CASTRo Leite [FIG. 127, 1928];

- Francisco Acquarone (Acqua) anúncios para a pasta e SABONETE NANCY [FIG. 116, 1933], IndANTHREN [FIG. 117, 1932], KaOl, TALCOLin, A EQÜITATIVA, CAIXA ECONOMICA [FIG. 118, 1935];

- Lanza que executou para a revista Ariel, anúncios para a LoÇão ANTICASPA, POMADA ONKEN [FIG. 108, 1924], e alguns outros para a casa de modas Elisa Giaccone Macelloni \& CA [FIG. 110, 1924] e CASA GAGLIANO \& CA [FIG. 109, 1924];

- Orestes Acquarone (O. Acquarone, OAcq e O. A. Salaberry) autor do conhecido anúncio do xarope Tosse? BROMIL [FIG. 121, 1924/1929?] e NUTRION [FIG. 123, 1929];

- Orestes Acquarone Filho (Orestes Acquarone, Acquarone Filho) anúncios para o xarope Bromil [FIG. 119, 1930] e para a Loteria Federal do Brasil [FIG. 120, 1933];

- Paim Vieira com sua contribuição também para Ariel, já citada anteriormente [FIGS. 24, 32-37, 39].

Afora uma produção de anúncios vinculados às revistas ilustradas Paim Vieira. Alvarus e Belmonte exemplificam outros modos possíveis de atuação desses profissionais junto à publicidade, pois o primeiro foi funcionário em São Paulo da empresa Rhodia executando sua "propaganda visual que ia desde os anúncios às ilustrações e montagem de stands”, ${ }^{151}$ já Alvarus durante trinta e dois anos trabalhou na Caixa Econômica Federal, organizando em 1934 o seu Departamento de Publicidade ${ }^{152}$ e Belmonte que, em meados da década de 1920, foi chefe do Departamento de Publicidade do escritório da Metro Goldwyn-Mayer, em São Paulo. Finalmente,

${ }^{151}$ Ver Yone Soares de Lima, op. cit., p. 195.

152 “CEF expõe o melhor sobre a vida e obra de Alvarus”, O Fluminense, Niterói, 24 abr. 1988. 
acrescentamos Orestes Acquarone Filho que em 1922 foi convidado a colaborar no setor de publicidade do laboratório farmacêutico nacional Daudt \& Oliveira.

No período estudado, o que se verifica é uma multiplicidade de oferta de trabalho aos artistas do lápis mesmo que sob uma grande concorrência, visto que muitos deles trabalhavam para as mesmas publicações. Para melhor avaliarmos o campo de atuação desses profissionais, além da propaganda comercial, localizamos publicidades de outras naturezas veiculadas em cartões postais, como o de Monsã para a $1^{\text {a }}$ ExPOSIÇÃo FilatÉLICA JUVENIL DE MinAs GERAIS (1939) e o de Alberto Lima para a 1a SEMAna FilatélicA JuVEnil do Rio DE JANEIRO (1948), em cartazes para a SeCretaria da SAÚdE E AssistênCia de K. Lixto (1938 ou 1948), ou para a SAÚdE Pública, Indústria, Comércio E Agricultura, a exemplo de Pelas Vias RESPIRATÓRIAs de Monsã, ${ }^{153}$ e em folhetos para o SERVIÇO NACIONAL DE EDUCAÇÃo SANITÁRIA como é o caso de Luiz Sá (1946).

Um testemunho de como a caricatura estava associada à propaganda e a outras formas gráficas, pode ser conferida na revista Ritmo $^{154}$ por meio do seguinte anúncio:

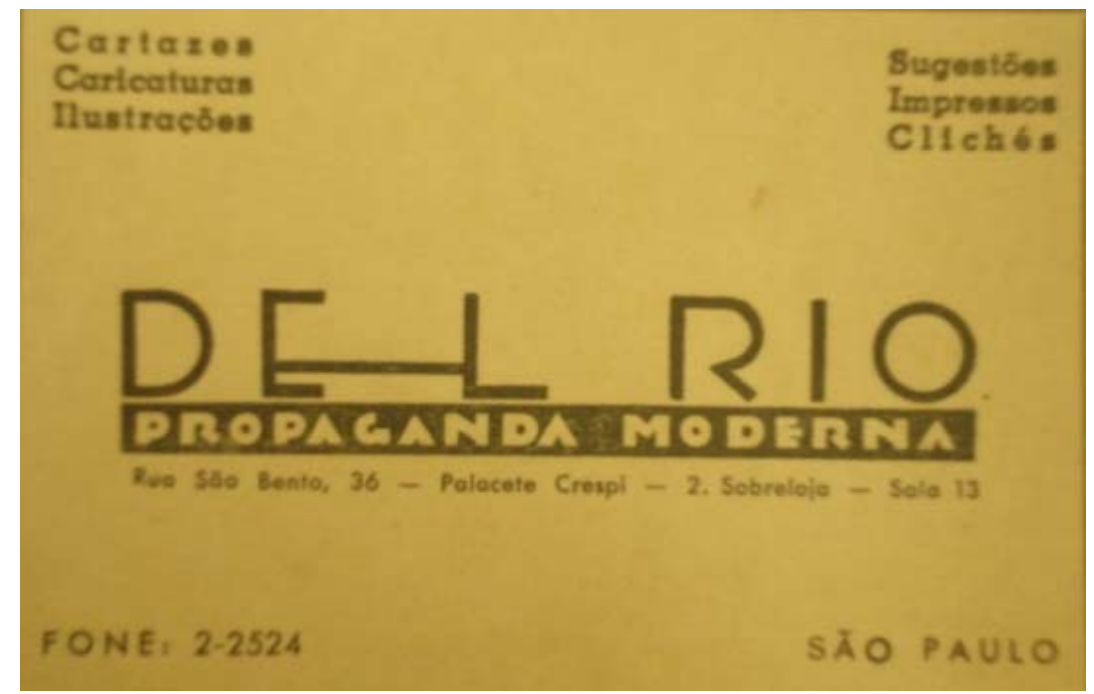

*Ritmo, São Paulo, (1): III capa, nov. 1935.

\footnotetext{
${ }^{153}$ Os mineiros Monsã e Érico de Paula fundaram a primeira agência de propaganda de Belo Horizonte.

${ }^{154}$ Ver Ritmo, São Paulo, (1): III capa, nov. 1935. Dentre o corpo de profissionais do periódico, Del Rio era o responsável pela “Téchnica”, sendo que a capa deste número é de sua autoria.
} 
Complementando a informação última, Aline Haluch ao recuperar dois anúncios de 1922 do estúdio de Ivan*, ilustrador da revista A Maçã, nos torna possível verificar a diversidade de serviços profissionais que um mesmo artista se dispunha a executar, no caso, o desenho artístico, o comercial, o industrial, os desenhos de construções em geral, os desenhos de máquinas e a decoração. ${ }^{155}$
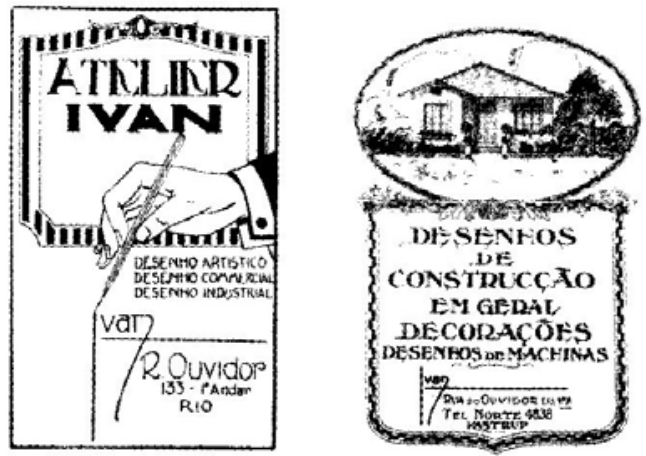

* Rafael Cardoso (org.), $\mathbf{O}$ design brasileiro antes do design: aspectos da história gráfica, 1870-1960, São Paulo: Cosac Naify, 2005, p. 120.

Se nos anos de 1910 a nossa propaganda ainda não tinha se impregnado e sido submetida aos valores norte-americanos e ainda dispúnhamos de "um estilo brasileiro" como defende Caio Domingues, ${ }^{156}$ nada mais próximo do público do que a propaganda empregar os traços dos caricaturistas para veicular suas mensagens. Assim é que Ana Maria Belluzzo identificou, em seu estudo sobre Voltolino, uma ponte aceitável entre a publicidade e a caricatura que perpassa pela manutenção de uma comunicação direta entre arte e vida. Assim, infere a autora

Voltolino é já o artista profissional de certa modalidade de veículo de comunicação. È fato significativo ter sido procurado para a realização de reclames do guaraná Zanotta e do chocolate Lacta, dos cigarros Sudan Extra, dos pianos Bechstein que eram vendidos na Casa Beethoven. É provável que seja também de sua autoria o logotipo da Casa Fausto, como supôs o professor Flávio Motta, O artista era convidado para

\footnotetext{
155 Aline Haluch, “A Maçã e a renovação do design editorial na década de 1920”, in Rafael Cardoso (org.), $O$ design brasileiro antes do design: aspectos da história gráfica, 1870-1960, São Paulo: Cosac Naify, 2005, pp. 120-121. Ivan é o nome adotado pelo ilustrador Manlius Mello.

${ }^{156}$ Sobre o “estilo brasileiro” na propaganda consultar Caio A Domingues, op. cit., pp. 33-40.
} 
colaborar com o comércio elegante porque dominava a sinuosidade e a linha orgânica que caracterizou o art-nouveau e porque, no geral, detinha o know-how da comunicação social e desencumbia-se das tarefas com recursos da linguagem direta, que desprendia da forma caricatural, quando não o fazia com a própria caricatura. O mesmo ocorria com as ilustrações de livros. ${ }^{157}$

${ }^{157}$ Ana Maria de Moraes Belluzzo, op. cit., p. 266. 


\subsubsection{DOS ARTISTAS PUBLICITÁRIOS}

Eu sou um Diretor de Arte.

Eu não fui contratado para fazer bonitos quadros, para exibir minha técnica pessoal ou para impressionar as pessoas com meus desenhos.

Eu fui contratado para vender produtos.

Eu sou responsável pela criação de anúncios que vendam produtos.

$\mathrm{Eu}$ faço parte de uma equipe.

Eu devo conhecer tudo a respeito do produto.

Eu nunca sacrifico uma boa idéia de venda por outra mais bonita. ${ }^{158}$

Em 1968, a revista GAM publicou uma entrevista com alguns diretores de arte de importantes agências de propaganda do país, os quais foram submetidos a duas únicas perguntas:

1. Será a arte publicitária tão válida como a arte livre?

2. O artista publicitário ficará na História da Arte como Gauguin, Van Gogh, Picasso, etc.? ${ }^{159}$

De modo geral, as respostas às duas perguntas foram negativas e circularam em torno do "código de conduta” citado logo acima. Para os participantes foi consensual que a arte publicitária é

- arte condicionada a objetivos, às exigências dos anunciantes e a exigüidade do espaço em que a mensagem tem que ser contida;

- técnica de aplicação dos meios e recursos das artes plásticas à moderna técnica da comunicação de massas;

\footnotetext{
${ }^{158}$ Apud J. Loponte, “Os muitos conflitos da criação”, GAM: Galeria de Arte Moderna, Rio de Janeiro, (12): 33, 1968. Georg Olden, Diretor de Arte da McCann-Erickson de Nova York, apresentou numa conferência, da qual desconhecemos a sua data, esse "drástico código de conduta” para os artistas publicitários.

${ }^{159}$ Heitor Humberto de Andrade, “A arte que eles não fazem (I)”, GAM: Galeria de Arte Moderna, Rio de Janeiro, (11): 31, 1968. Participaram da enquête os profissionais Renata Griese (Norton), Oscar Gosso (McCann), Rodrigo Otavio (JMM), Fernando Silva (Benson), Lielsio de Azambuja (Standard), José Sadi Almada (Interamericana), Darcy Gonçalves (MPM), Fernando Arturo Gerardo (CIN), Sami Mattar (Grant) e Newton Rezende (Thompson).
} 
- produto de um grupo de criação, distante das manifestações individuais, de estilos próprios e inconfundíveis, portanto sem autoria;

- efêmera e circuntancial, perdurando somente enquanto veiculada.

Quanto à segunda resposta, ela seria afirmativa somente no caso da existência de uma carreira de pintor paralela à de artista publicitário.

As entrevistas vinham acompanhadas dos currículos dos profissionais pesquisados, que, com exceção de dois que não informaram sobre as suas formações e escolhas e outros dois que se interessavam por outras atividades artísticas (cinema, televisão e moda) demonstraram expressivo interesse pela pintura, seja pelos seus estudos iniciais na área das artes plásticas ou participação em exposições individuais e coletivas, seja como hobby ou ainda como projeto a se dedicar no futuro.

Observarmos que o desejo de pintar e de ser pintor, mesmo para aqueles que abraçaram inicialmente em suas carreiras as artes gráficas direcionadas à publicidade e à ilustração, mais cedo ou mais tarde se manifesta. Os artistas publicitários inquietam-se e desejam estar no pólo da "arte livre”, ${ }^{160}$ alinhando-se a uma visão romantizada da arte. E nessa relação de interessados acrescentamos Hermelindo Fiaminghi, Charlotta Adlerová, Gerhard Orthof e Vitório Gheno.

Uma outra aproximação ao assunto pode ser obtida, ao analisarmos a natureza das perguntas e de certo modo também as suas respostas, auxiliando-nos na compreensão e no esboço da profissão do artista publicitário brasileiro consoante à época, isto se estende a própria visão que o profissional tecia de seu trabalho na publicidade. Notamos que a matéria veiculada na publicação GAM é dos anos finais da década de 1960, portanto um período que dispunha do reconhecimento público da profissão publicitária, de um bom número de agências de propaganda, de um ensino institucionalizado, de órgãos representativos da classe e de algumas publicações especializadas na área. Perfil, este, que se afasta daquele dos anos de 1920-1940, quando a publicidade no Brasil iniciava seus passos rumo a uma propaganda moderna amparada pelo modelo americano.

\footnotetext{
${ }^{160}$ As aspas se devem à discordância de Lyotard. Este não considera a arte livre, pois reconhece a existência de "liberdade dentro de coerções de qualquer nível, conscientes e inconscientes", a exemplo da arte gráfica. Consultar Jean-François Lyotard, "Paradoxo sobre o artista gráfico", in Moralidades pós-modernas, Campinas: Papirus, 1996, p. 39.
} 
Feitas essas observações, que poderiam conduzir na época a uma reflexão mais aberta e copiosa do campo artístico tanto em relação à arte livre quanto à arte publicitária, temos que, em suas formulações Heitor Humberto de Andrade impõe de imediato uma problemática comparação entre essas duas artes e, entre o artista livre e o artista publicitário. Parece-nos evidente que arte livre para o entrevistador corresponde às artes maiores, as tradicionais belas artes. Por sua vez, o questionamento - se a arte publicitária é tão válida como a arte livre ou então se o artista publicitário ficará na História da Arte $^{161}$ - de antemão, posiciona hierarquicamente a arte livre num patamar superior ao da arte publicitária. É como se esta não tivesse seu próprio campo de legitimação precisando se submeter a outra esfera artística para o seu reconhecimento. Prevalece, sobretudo no enfoque do entrevistador uma relação entre arte e publicidade assentada na imagem, desconsiderando suas distintas naturezas, diferenças de produção, função e recepção. Subentende-se que tanto as perguntas quanto as respostas gravitam e investem na manutenção da tradição, isto é nas hierarquias artísticas, e de certa maneira no monopólio da pintura.

Um parêntese. Para confirmar a especificidade da arte publicitária, as análises dos conteúdos dos cursos do Anteprojeto da Escola de Propaganda do Museu de Arte de São Paulo (1951), entre eles: Técnica de Esboço (layout), Arte Final e Produção e Artes Gráficas, ${ }^{162}$ permitiu verificar que os seus ensinos centralizavam e se desenvolviam significativamente no âmbito técnico e teórico das artes gráficas e tipográficas, distanciando-se da grade curricular das escolas superiores de arte, o que reforça as diferenças de produção e recepção entre a arte publicitária e a arte pura.

Loponte encontra uma saída para essa querela, ao transferir essa discussão do campo artístico para o estético:

A propaganda não constitui um capítulo específico das artes plásticas. Ela é um processo assimilador de técnicas, as mais variadas; uma aglutinadora de todas as formas de expressão artística e de ilimitadas gamas do conhecimento humano. Para ela confluem todas as manifestações da inteligência e todos os recursos da moderna tecnologia. Podemos considerá-la a ponte lançada entre as grandes massas

\footnotetext{
${ }^{161}$ Grifos nossos.

162 Rodolfo Lima Martensen, Desafio de quatro santos: memórias, São Paulo: LR Editores, 1983, p. 282. No item Anexos da tese, encontra-se reproduzido o conteúdo do curso Arte Final, o qual nos permite confirmar que o ensino da arte publicitária estava direcionado as artes gráficas e tipográficas.
} 
consumidoras de produtos, serviços e ideologias e os laboratórios experimentais de comunicação. O artista chamado para fazer parte do sistema, não perde substância. Continua o mesmo artista na plenitude da sua capacidade criadora mesmo que não a possa manifestar tal como o desejaria. As limitações que lhe são impostas em nada afetam o seu talento, a sua sensibilidade. Dele a propaganda retira o essencial para o seu uso. Ao esboçar o anúncio, o artista aplica as regras de composição que melhor convenham ao tema proposto. Nesse momento, a sua liberdade criadora é integral. Mas o anúncio não, em si mesmo, uma obra de arte.

[...]

Não há fronteiras entre a chamada "arte publicitária” e a "arte livre”. O artista é uno e indivisível quer coloque no quadro uma lavadora automática ou uma forma abstrata. ${ }^{163}$

Essa visão mais atualizada, também partilhada ou então próxima dos princípios de outros teóricos como Juan Acha, Marc Le Bot, Dino Formaggio e Mikel Dufrenne, associada ao reconhecimento das limitações do artista publicitário, que podem ser identificadas com aquelas coerções apresentadas por Lyotard $^{164}$ e que envolvem os artistas gráficos e suas produções, tornam esses profissionais intérpretes e ao mesmo tempo artistas. Artistas sim, mas

promotores. Têm de propor sua obra e outra coisa além de sua obra, a coisa. Sua obra é um objeto que deve induzir a outra coisa além do prazer de sua beleza. É uma arte “aplicada”, como se diz. Exige do artista gráfico uma humildade de servidor, talvez uma humilhação. O artista gráfico assina um contrato, pode então (em princípio) escolher a coisa que o seu objeto vai promover. Mas o contrato estipula que o objeto deve promover a coisa. Ele interpreta, portanto, mas aqui no sentido de um comediante, que também é um servidor. Como o do comediante, existe um paradoxo do artista gráfico. Quanto mais fizer o vazio dentro de si, para deixar-se habitar pela coisa, mais o objeto será fiel à coisa que promove. Fidelidade que não é de mimetismo, mas de invenção. ${ }^{165}$

Nessa direção que valoriza a dimensão estética e não unicamente a artística e que se afasta das tradicionais instâncias de legitimação, podemos também citar o autor Mikel Dufrenne que propõe "introduzir na arte a diversidade como unidade” tal qual a ciência que encerra várias especialidades, e transferir a importância da arte não para o

\footnotetext{
163 J. Loponte, op. cit., p. 33.

${ }^{164}$ As coerções que Lyotard propõe e que agem sobre o artista gráfico se resumem a: ser agradável, persuasivo, correto, intrigante e intérprete, e ainda deve-se ter em conta a efemeridade do objeto e as sensibilidades temporárias do público. Jean-François Lyotard. op. cit., pp. 37-49.

${ }^{165}$ Idem, p. 48.
} 
seu produto final, mas sim para a experiência estética. Em busca da ampliação do campo da arte, o autor se pergunta se existem princípios em grau de classificar a pluralidade das artes? Mas, "neste caso não é mais uma classificação autoritária a distinguir a arte da não arte, e a caracterizar as diversas artes; são as diversas práticas a reivindicar seu direito a arte”. 166

Nesse mesmo caminho Acha se posiciona:

Talvez o mais importante da diferenciação entre o estético e o artístico seja que nos permite situarmos na realidade da correlação dialética sujeito-objeto, para centrar o estético no sujeito, produto social e executor da produção e do consumo; e identificar o artístico com o objeto, os sistemas produtivos e a cultura que isto pressupõe como produto humano [...]. ${ }^{167}$

Se o artista gráfico, o designer ou o artista publicitário, reúnem em si o artista e o técnico, porque não pensá-los de outra forma, fora das fronteiras prefixadas, pois se as artes maiores foram e de certa maneira ainda estão circunscritas institucionalmente, as artes menores que mapeiam a sua periferia não encontram definição e classificação em um sistema tal qual.

A vontade de pintar do artista publicitário também pode ser analisada tendo em conta que o designer gráfico, denominação mais precisa, tem entre suas atividades ligadas à produção a concepção de projetos de uma ou mais configurações de um produto, lançando mão dos recursos estéticos convenientes aos objetivos prédeterminados. Portanto, diferentemente da arte, esses profissionais não se envolvem diretamente com a execução manual e esta exclusão pode gerar nestes a necessidade de processar um fazer artístico enquanto manipulação de uma materialidade. Acrescentamos que o designer gráfico, enquanto produtor estético, além da renúncia a expressividade individualista e autobiográfica, pode ter suas idéias e criações descartadas em função de uma inadequação aos fins, de modo a ficarem suspensas, mas passíveis de serem emprestadas, no caso em particular, à pintura.

Dentre os profissionais gráficos na publicidade brasileira, figuram como os mais importantes Jean Gabriel Villin, Mirga, Barão Puttkamer, Franz Kohout, Gerhard Orthof, Carlota, erico e Ary Fagundes.

\footnotetext{
${ }^{166}$ Mikel Dufrenne, “L'arte e le arti”, in Idem; Dino Formaggio, Trattato di estetica, Milano: Mondadori, v.2, 1981, pp. 151-153.

${ }^{167}$ Juan Acha, op. cit., p. 23.
} 


\subsection{CONSIDERAÇÕES FINAIS}

O sucesso das revistas ilustradas junto ao público foi de fundamental importância para a conformação de um circuito extra-artístico oficial, pelo menos nas três primeiras décadas do século XX, agregando e empregando caricaturistas, desenhistas, ilustradores e literatos. Se por um lado este fato propiciou o desenvolvimento da nossa arte gráfica mesmo que a princípio ditado pelos modelos estrangeiros, por outro lado gerou novos espaços produtivos e consequentemente novas demandas de profissionais; e é nesse conjunto de circunstâncias que concorre o envolvimento dos artistas do lápis e os da pena na publicidade brasileira no período estudado.

Sem tradição na publicidade, essas participações de certo modo determinou, inicialmente, o rumo da nossa arte publicitária que na ausência de profissionais especializados, mesmo porque a publicidade ainda não havia se constituído como uma profissão, estabeleceu de antemão um compromisso com o humor, tanto no plano redacional quanto no gráfico, definindo um acervo típico de nossa propaganda, que é reconhecido como um “estilo brasileiro”. Por outro viés, os profissionais do lápis, em suas diversas atuações, mantiveram suas produções na área da propaganda próximas das suas formas usuais de expressão, com algumas adaptações que o decorrer dos anos impôs em função de modismos ou de desgaste das velhas formas empregadas, a exemplo do uso dos políticos na mensagem publicitária. Contudo, desde o final dos anos 30 à década seguinte, prevalece a ilustração e não mais a caricatura, mesmo quando o anúncio comercial era elaborado por um caricaturista.

Como era de se esperar, mesmo porque já dispunha de certo status, despreendendo-se da sua servilidade de cópia e tradução de obras de arte, o desenho foi a ferramenta criativa dos profissionais do lápis e a linguagem substancial da arte publicitária veiculada no formato de anúncios comerciais e, que ao se sobrepor na prática à linguagem pictórica, determinou um distanciamento da nossa publicidade dos pintores e do cartaz. Uma comparação com o quadro europeu indica que a complexa relação entre arte/artistas e publicidade se desenvolveu atrelada à cartazística, e este fato teve influência na disposição do mercado de trabalho.

No Brasil, somente em anos bem posteriores, o cartaz comercial ganha força, com a participação dos profissionais das agências de propaganda americanas e por 
intermédio dos europeus com interesses e formações na área das artes gráficas, e aproveitamos para ressaltar que a pesquisa não localizou uma produção cartazística comercial dos nossos artistas plásticos de primeira linha.

Lançamos a hipótese de que os artistas do lápis, por suas distâncias do meio acadêmico e das normas produtivas cultas e, por não encontrarem resistência e dificuldades de aceitação do público e de seus pares, tenham se exercitado nas novas demandas profissionais que surgiam no mercado cultural com mais flexibilidade. E, do mesmo modo que os poetas da Belle Époque, os artistas do lápis, souberam arregimentar o grupo criando não só um corporativismo, mas igualmente um campo artístico particular, que lhes possibilitou o exercício de suas próprias ideologias e interesses, aplicáveis não só nas ilustrações e nas caricaturas, mas também nos anúncios comerciais, por estes serem considerados uma extensão e não uma ruptura ou um desvio de produção e/ou de trajetória artística. Se compararmos a expressividade e a "força" dos profissionais do lápis em seu conjunto, podemos entender o insucesso de Visconti, uma voz quase que isolada no contexto da época, e que se dirigia a um público inexistente ou em formação, a um meio artístico que não dispunha de agrupamentos de artistas defensores das artes aplicadas, tal como propugnava o Art Nouveau em seus anos iniciais e que arregimentou em torno de si a Société des Artistes Décorateurs.

O estudo da Revista do Globo apontou para o reconhecimento da sua atuação como um sistema não oficial que ganhou importância dentro de um tímido circuito artístico, como escola ao formar artistas gráficos em seus constantes exercícios profissionais, e como agente empregador de artistas plásticos, que estavam vinculados ao sistema acadêmico local. Procuramos demonstrar não somente práticas de época extensivas a outros periódicos, mas também os conflitos e a situação de inferioridade a que eram submetidos os artistas que trabalhavam com a arte comercial, revelando o sistema de pensamento e as estruturas artísticas do momento. Verificamos como a imprensa editorial estabelece, em função de suas prioridades, as hierarquias dos produtos gráficos e a confirmação do envolvimento do profissional das artes gráficas numa pluralidade de atividades. E, com clareza percebemos que auto-imagem do desenhista oscila entre uma identificação artística e uma técnica, devido a uma necessidade de entender e participar de métodos e sistemas de produção, a exemplo das cópias e criação de letras, da obtenção das cores em função dos processos de impressão, entre outros. 
Concluímos do que precedeu ao desenvolvimento dos temas, que o nosso debate em torno das artes aplicadas foi importado do plano internacional e foi de fraca repercussão, devido, entre outros, ao despreparo do nosso meio artístico. A AIBA e a sua sucessora distanciaram-se na prática das artes menores, a reformulação do ensino primário e secundário do desenho demandou um longo e lento processo de reformulação e institucionalização; o pouco interesse e incentivo das indústrias nacionais pelo assunto e um público distante dos valores das artes aplicadas, todos esses fatores caracterizam um mercado que não estabelecia parcerias com os artistas, mas sim com os artesãos, sobretudo os estrangeiros.

No outro pólo, o dos artistas, prevalece a visão romântica da arte, a lógica dual excludente, dedicação à arte maior ou à arte menor, mesmo sob a vigência dos nossos artistas plásticos modernistas, que, de modo geral, não viram na publicidade uma nova forma de expressão estética.

O envolvimento dos artistas plásticos nas atividades publicitárias deu-se na maioria das vezes esporadicamente em função de interesses particulares ou como suprimento financeiro em momentos difíceis; já para os artistas do lápis, por terem uma acentuada presença nos periódicos, sua participação foi uma via contínua por falta de profissionais especializados na área e não nos faltam exemplos. Dificilmente, afirmaríamos que a atividade publicitária transversalizou uma carreira pictórica de algum artista, talvez Fiaminghi seja um exemplo mais próximo deste caso.

No que concerne à criação artística e à criação publicitária, frequentemente encontramos a manutenção do peso dos esquemas tradicionais da arte, que não consideram as especificidades e que usam da assertiva "a arte cria e as arte aplicadas seguem”, porém, em posicionamento divergente, se posiciona Décio Pignatari ao comentar que a

arte e os meios de comunicação de massa mantêm relações bastante estranhas. Quando você pensa que esses meios devem tornar-se mais "artísticos" quando manipulados por um artista, aí é que se engana: raramente um pintor, por exemplo, produz boa obra gráfica (ToulouseLautrec é a primeira grande exceção). E quando você pensa que uma obra chamada comercial deve ser inferior, como arte, a uma obra desinteressada, aí você também se engana e a sua crença não é valida pelos fatos. O maior exemplo está no cinema: as grandes obras cinematográficas são realizações comerciais e não obras marginais ou udigrude. 
Uma outra diferença é a seguinte: enquanto os movimentos artísticos (impressionismo, cubismo, surrealismo, etc.) sucedem-se uns aos outros na moda e na preferência do público intelectual, os diferentes meios de massa é que se sucedem na preferência do grande público: a ópera e o teatro são suplantados pelo cinema, que, por sua vez, é suplantado pela televisão. Outra curiosidade é que o meio antigo tende a se transformar em arte, enquanto o meio novo passa a sofrer todos os ataques dos intelectuais (vulgar, alienante, etc.). ${ }^{168}$

Partindo do pressuposto que a arte publicitária, além do seu aspecto técnico e científico, é também é uma atividade artística, no decorrer do capítulo constatamos três lugares que lhe são possíveis e que se apresentam consoante a discussões teóricas datadas: uma arte aplicada que guarda grande proximidade com as artes nobres, mostrando uma continuidade e assimilação das principais tendências artísticas; num segundo momento, a arte menor deseja se fundir na vida, seguindo um projeto de arte social, arte útil e para todos; finalmente, e em associação à especificidade produtiva, a visão do conceber como um projeto de comunicação, que envolve a divisão de trabalho, a pesquisa e a solução dos problemas.

${ }^{168}$ Décio Pignatari, Signagem da televisão, São Paulo: Brasiliense, 1984, p. 9. 
Capítulo 3

ANÁLISE CRÍTICA 
As três mulheres do sabonete Araxá me invocam, me bouleversam, me hipnotizam. Oh, as três mulheres do sabonete Araxá às 4 horas da tarde! O meu reino pelas três mulheres do sabonete Araxá!

Que outros, não eu, a pedra cortem Para brutais vos adorarem, Ó brancaranas azedas, Mulatas cor da lua vêm saindo cor de prata Ou celestes africanas:

Que eu vivo, padeço e morro só pelas três mulheres do sabonete Araxá! São amigas, são irmãs, são amantes as três mulheres do sabonete Araxá? São prostitutas, são declamadoras, são acrobatas? São as três Marias?

Meu Deus, serão as três Marias?

A mais nua e doirada borboleta. Se a segunda casasse, eu ficava safado da vida, dava pra beber e nunca mais telefonava. Mas se a terceira morresse... Oh, então, nunca mais a minha vida outrora teria sido um festim!

Se me perguntassem: Queres ser estrela? queres ser rei? queres uma ilha no Pacifico? um bangalô em Copacabana? Eu responderia: Não quero nada disso, tetrarca. Eu só quero as três mulheres do sabonete Araxá: O meu reino pelas três mulheres do sabonete Araxá! ${ }^{1}$

Manuel Bandeira

\footnotetext{
${ }^{1}$ Manuel Bandeira, Estrela da vida inteira, São Paulo: Círculo do Livro, s.d., pp. 150-151.
} 


\subsection{DA CARICATURA À ILUSTRAÇÃO: A PRODUÇÃO DOS DESENHISTAS DE IMPRENSA} NOS RECLAMES

Fazer um anúncio ilustrado e colorido na Mercúrio é tê-lo em todas as paredes em todas as coleções, em todas as casas. ${ }^{2}$

No Brasil, o apelo à associação da imprensa ilustrada à propaganda nascente remonta aos tempos de A Lanterna Mágica de Manuel de Araújo Porto-Alegre. Rafael Mendes de Carvalho, sob supervisão de seu mestre, se ocupa dos desenhos de tal folhetim ou jornal ilustrado, promovendo uma adjunção dos anúncios e cartazes à caricatura (a exemplo de LAVERNA E BELCHIOR PROJETANDO, LAVERNA E BELCHIOR DIANTE DA TIPOGRAFIA, LAVERNA E BELCHIOR PRÓXIMOS AO CHAFARIZ DE MESTRE VALENTIM), que servem de pano de fundo tanto para as observações críticas e irônicas de Porto-Alegre a respeito da industrialização da imagem e do texto, como também e com mais propriedade à sátira dirigida à sociedade urbana do Rio de Janeiro. ${ }^{3}$ Se a incorporação da publicidade nesse gênero artístico ainda não visa diretamente a divulgação de produtos e serviços, como virá a ocorrer em anos bem posteriores, mas é “discretamente”, pelo viés visual, uma das causas e pretexto para se questionar os valores da modernidade que transformam e ocupam o espaço urbano - que na forma de cartazes-anúncios afixados em muros e fachadas configuraram na França o estado de affichomanie. Por sua vez, as legendas são uma forte investida na função e no uso que se faz da publicidade e de seus suportes, como observa Heliana Angotti Salgueiro:

\footnotetext{
${ }^{2}$ Publicado originalmente na revista Mercúrio, 21 jul. 1898 e citado em Monica Pimenta Velloso, Modernismo no Rio de Janeiro: turunas e quixotes, Rio de Janeiro: Editora Fundação Getulio Vargas, 1996, p. 60.

${ }^{3}$ A Lanterna Mágica (Rio de Janeiro, 1844-45) tem seu texto atribuído a Manuel de Araújo de Porto-Alegre e as 19 caricaturas ao seu discípulo Rafael Mendes de Carvalho. Para um aprofundamento do assunto e consulta às imagens mencionadas, remetemos o leitor ao catálogo da exposição: A comédia urbana: de Daumier a Porto-Alegre, São Paulo: Museu de Arte Brasileira - Fundação Armando Alvares Penteado, 26 abr. - 22 jun. 2003, pp. 92, 103 e 105. Curadoria de Heliana Angotti Salgueiro.
} 
Na mesma linha Laverno, O Macaire de Porto-Alegre, evoca ironicamente, logo nos primeiros episódios de A Lanterna Mágica, a necessidade da propaganda pessoal, seja em anúncios de jornais, seja por meio de "cartazes monstros, à maneira de Paris, e de alguns artigos fosforescentes, todos cheios de campanudas [sic] e indefiníveis frases”. E pergunta a Belchior, seu servidor:

[...] concebeste até onde pode chegar a força de um anúncio?

[...] o anúncio em país de pensamento e palavra livre onde todas as verdades e todas as mentiras se dizem, se escrevem e se propagam, tira, restitui e suspende o crédito do abalizado capitalista, como do mais escoimado pelintra...

Em vários episódios, como nas litografias de Honoré Daumier, a publicidade do negócio é ironizada. Tramando novos golpes, Laverno ainda observa: "um anúncio nos dará a capacidade intelectual, a instrução, a moralidade necessárias para o bom desempenho da nossa empresa”. E completa: "por meio de uma polêmica cotidiana nos jornais [...] nos faremos conhecidos de todo o mundo; uma polêmica escandalosa vale um tesouro para qualquer especulador". 4

Portanto, se em meados dos oitocentos a nossa caricatura já se voltava à publicidade, mesmo que sob motivação dos modelos e experiências de Porto-Alegre tomadas de um cenário tão distinto do nosso como o parisiense daquela época, essa relação irá se alterar profundamente a partir da passagem do século, quando os caricaturistas-periodistas servem-se dela diretamente, agregando-lhe valores estéticos, como fonte de recursos financeiros, como suporte para as experiências artísticas descompromissadas das regras das belas artes e como veículo alternativo de divulgação de seus nomes e talentos; por outro lado, a propaganda deles se serve para alavancar seus produtos e marcas.

Aceita e assumida essa relação, podemos melhor compreender a epígrafe que abre este item e que dá conta desse novo encaminhamento de valorização da publicidade e da sua aproximação à arte. Isso ocorre não só devido à publicidade ser assunto e matéria constitutiva da modernidade, mas também ao fato dos artistas do lápis em seu conjunto a ela se dedicarem numa época em que a ilustração é tida como um grande e rendoso atrativo para financiar as revistas; participando, assim, dos distintos filamentos artísticos, essa colaboração bem pode se estender à publicidade. Daí a estreita relação dos caricaturistas e ilustradores com as matérias publicitárias, que passam a ser aceitas, por estes, como um meio artístico em circulação e também como uma forma de comunicação entre o anunciante e o leitor.

\footnotetext{
${ }^{4}$ Idem, pp. 57-58.
} 
Essa simbiose é captada por Voltolino em As NOVAS DECORAÇÕES DO CAFÉ GUARANY [FIG. 149, 1911], que ao compor seu trabalho caricato com as frases dos cartazes de rua não só demonstra dominar a comunicação entre arte e vida, como também “contaminar” seu espaço particular, o da arte, com elementos estéticos modernos: as palavras impressas que mobíliam o espaço urbano. ${ }^{5}$

5 Paula Ester Janovitch, Preso por trocadilho: a imprensa de narrativa irreverente paulistana 1900-1911, São Paulo: Alameda, 2006, p. 315. AS NOVAS DECORAÇÕES DO CAFÉ GUARANY foi publicada em O Pirralho, São Paulo, 19 ago. 1911. 


\subsubsection{CARICATURISTAS E CARICATURAS COMERCIAIS}

É isso que marca o verdadeiro artista, sempre durável e vivaz, inclusive nessas obras fugazes, por assim dizer suspensas nos acontecimentos, denominadas caricaturas. Baudelaire $^{6}$

Não foi nossa preocupação inventariar os modos e os temas empregados pelos caricaturistas nas peças de cunho publicitário comercial, e se às vezes assim procedemos é tão somente para apresentar as possíveis formas de comunicação social que a caricatura propõe ao público ao mesmo tempo em que o seu esboço nos favorece na reconstituição de tendências de época. Não obstante, de modo geral, encontramo-las na divulgação de diversos gêneros, entre eles bebidas, alimentos, saúde (medicamentos), beleza, vestuário, acessórios e tabaco.

Da fase dos reclames e ainda quando o discurso publicitário estava associado ao literário encontramos dentre as estruturas de informação, textos publicitários tanto em prosa quanto em verso, são exemplos de

- versificados e humorísticos: A SAÚDE DA MULHER de J. Carlos [FIG. 138, s.d], BROMIL [FIG. 152, 1917] de Romano, e os do cigarro York - Os Aliados de Sib e No SALON de Oyrk [FIGS. 173, 175, 1918];

- dialogado: Os PAPÁveis de J. Carlos [FIG. 136, 1917] e LACTA [FIG. 147, 1919] de Voltolino;

- informativos: de J. Carlos, As ÁGUAS MAGNESIANA E GAZOSA DE S. LOURENÇO [FIG. 137, 1911].

Dentre os anúncios comerciais que se ligam à caricatura, pela imagem figurativa em si associada ou não a um discurso literário, exemplificamos as linhas

\footnotetext{
${ }^{6}$ Apud Monica Pimenta Velloso, op. cit., p. 108.
} 
- do testemunhal: o portrait-charge de Pinheiro Machado, As ÁGUAS MAGNESIANA E GAZOSA DE S. LOURENÇO [FIG. 137];

- da caricatura acompanhada de versos: A SAÚDE DA MUlHer [FIG. 138], BROMIL [FIG. 152], NO SALON [FIG. 175];

- dos acontecimentos políticos: o cigarro York - Os Aliados [FIG. 173];

- das imagens de políticos: OS PAPÁVEIS [FIG. 136] e LACTA [FIG. 147].

Reafirmamos que não temos o propósito de enquadrar nossas análises nas listadas tipologias, mas delas lançaremos mão quando julgarmos oportuno ao estudo. Alertamos sobre a dificuldade que às vezes encontrarmos no reconhecimento das fronteiras da caricatura, ou melhor, aquela faixa de transição ocupada tanto pela caricatura como pelo desenho gráfico de humor ou ilustração.

Nossa pesquisa revelou que devemos precisar o emprego que fazemos do termo caricatura, mesmo quando nos dirigimos aos seus específicos profissionais, pois as peças publicitárias não mais correspondem àquela conceituação que é dependente de um discurso literário para sua apreensão e que conjuntamente emprega a deformação formal, o exagero, a distorção, o grotesco, e o humor mais ácido e agressivo.

Adotamos por caricatura a sua versão mais atualizada, aquela que permeia a produção brasileira dos finais dos anos 10 e que adentra os anos 20, e que tem por suas principais características: o rompimento com a mimese e o desprezo pelas regras de proporção dos corpos humanos, o tratamento irônico de seus modelos acompanhado do emprego de um humor leve e divertido, o começo de um investimento na economia de traços e no livre uso da cor, e a incorporação de temas inusitados e atuais. Porém, aceitamos o fato de nossos exemplos ainda dependerem dos versos e dos longos textos. Talvez, as nossas caricaturas com fins comerciais não sejam os melhores exemplares quanto à redução do uso de traços, pois eles são do final da década de 1910, mas em Voltolino e J. Carlos já se detecta uma reorientação para a síntese formal.

Se os recursos acima apontam para um distanciamento da arte acadêmica, a relação entre as belas artes e a caricatura pode melhor ser sentida em No SALON de Oyrk [FIG. 175], um dos pseudônimos de K. Lixto. Neste caso, como em outros é necessário que o leitor se apóie na mensagem textual para entender a visual. Dificilmente, poderíamos dizer que se trata de uma caricatura e, talvez este caso, seja um dos exemplos-limite entre a caricatura e a ilustração. K. Lixto compõe a sua peça dispensando os traços agressivos e deformantes, esmera-se numa meticulosidade 
delicada e descritiva para representar uma cena bucólica, na qual o pintor paisagista Batista da Costa se exercita com os pincéis. A cena desenhada nos causa um estranhamento por sua imobilidade, tudo no seu devido lugar, talvez uma alusão de como deveria ser uma boa e bem feita pintura. O título No SALON desfere o golpe final do caricaturista, que com um humor irônico e educado opera um sutil ataque à instituição oficial artística vigente, através de um dos seus membros. Uma crítica a um sistema que acolhe as exposições e os salões de arte, mas que por sua vez, exclui os humoristas do traço. Longe de uma passividade, os profissionais do humor se organizam e promovem suas próprias exposições e salões, por vezes contando com os espaços físicos das revistas com as quais mantêm vínculos.

Por sua vez, São Paulo representado pelo sintético e ágil traço de Voltolino renova e atualiza a forma tradicional de representação da baiana, ao incorporar em seu tabuleiro de doces marcas industrializadas do mercado, num híbrido reclame, por servir a duas marcas: LACTA e GUARANÁ-ESPUMANTE [FIG. 145, 1926].

A figura típica da baiana também constitui o mote de outra peça publicitária desse caricaturista que conta com um texto âncora em forma de diálogo. Na cena, Rui Barbosa tem sua cabeça deformada pelo agigantamento, alusão à sua capacidade intelectual e à Biblioteca Nacional, ${ }^{7}$ em contraponto ao seu diminuto corpo e ao próprio corpo de forte presença física da mulher trabalhadora que vende os chocolates LACTA [FIG. 147]. E, é no texto que se desprende a ironia, na referência à oratória do político, que por si só não o leva a presidência, já que em 1919 estaria em sua quarta candidatura à presidência. Sobre esses anúncios e os tipos freqüentadores da rua, a exemplo dos ambulantes, comenta Ana Maria Beluzzo:

Certa vez, Voltolino substituiu os quitutes caseiros da bandeja da bahiana pelo chocolate da Lacta e pelo Guaraná Espumante da Zanotta. Era mais uma daquelas propagandas em série da Lacta Zanotta, que o tornaram famoso. E o chocolate e o guaraná também. Ele os colocou na mão de todas as personagens, e elas apresentavam, também, São Paulo inteiro com o chocolate e a guaraná na mão. Nesta época, a propaganda se servia dos recursos do caricaturista, que enriquecia seus desenhos com versos. A propaganda usava a sátira política. ${ }^{8}$

\footnotetext{
${ }^{7}$ Em verdade, trata-se de uma charge desenhada por Alfredo Cândido, publicada em Larva (18 set. 1903), na qual a Biblioteca Nacional ocupa o interior da cabeça de Rui Barbosa. Ver Herman Lima, História da caricatura no Brasil, Rio de Janeiro: José Olympio Editora, v.1, 1963, p. 279.

${ }^{8}$ Ana Maria de Moraes Belluzzo, Voltolino e as raízes do modernismo, São Paulo: Marco Zero, 1992, p. 177.
} 
Ainda na década de 20, Voltolino publica outras matérias publicitárias para o chocolate Lacta e o Guaraná Espumante, sendo que para este último o artista empresta às suas figuras femininas, responsáveis visualmente pela divulgação da bebida, atributos da indumentária indígena, referência nacional que se confirma no texto do reclame FALLA A SANCHEZ... pelo emprego da palavra Tupinambá. Voltolino, provavelmente se serve destes procedimentos para enfatizar a nacionalidade brasileira do guaraná, tornando-o de qualidade incomparável às bebidas estrangeiras. ${ }^{9}$

Outro anúncio de Voltolino para o GUARANÁ EsPUMANTE, uma forma autopromocional do livro Narizinho de Monteiro Lobato [FIG. 146, déc. 20] que apesar de se utilizar de uma construção caricaturesca zoomorfica, não investe no grotesco e sim numa comicidade descompromissada, afim com os personagens do livro. E, em seu texto Monteiro Lobato, "na libélula, comenta com o aeronauta Edu Chaves: 'Vês? Eu andava com a cabeça vazia. Tomei Guaraná Espumante e todo esse mundinho maravilhoso saiu dentro da cachola!..., „10

O cômico solto também se encontra presente no anúncio a cores da CASA MiCHEL [FIG. 148, s.d.], que é ao mesmo tempo intrigante pelo ponto de interrogação que nos impõe nos gestos e as expressões que envolvem o grupo masculino do primeiro plano e aqueles advindos do menino sentado na linha vermelha da cercadura à esquerda. A multidão, a massa humana em perspectiva, que se orienta para o plano de fundo estabelece relação com a agigantada alegoria feminina, que, por suas cores, alude à França e, conseqüentemente, à origem da casa comercial. A presença de grossas linhas sinuosas e orgânicas do Art Nouveau se faz presente na moldura da cena e constitui, no caso de seus anúncios comerciais, um provável exemplo ímpar, se não considerarmos como sendo de sua autoria o logotipo da Casa Fausto. ${ }^{11}$

Na linha testemunhal, o portrait-charge de Pinheiro Machado, o “pente fino” como era conhecido o político na época, em As ÁGUAS MAGNESIANA E GAZOSA DE S. LOURENÇO [FIG. 137] distancia-se da conhecida produção de J. Carlos de traço gracioso,

\footnotetext{
${ }^{9}$ Idem, p. 181. Esses anúncios provavelmente são os mesmos que a pesquisadora de Voltolino mencionou na citação última. Pelo que pudemos verificar trata-se de reclames que se utilizam das várias etnias que viviam em São Paulo, a exemplo de FALLA A SANCHEZ..., uma referência à colônia espanhola. Estes reclames caricaturados foram publicados em Il Pasquino Coloniale, San Paolo, 9 apr. 1921 e em 22 ott. 1921.

${ }^{10}$ Apud Carmem Lucia de Azevedo, Monteiro Lobato: furacão na Botocúndia, São Paulo: Ed. SENAC São Paulo, 1997, p. 166.

${ }^{11}$ Apud Ana Maria de Moraes Belluzzo, op. cit., pp. 202 e 204. Anúncio publicado em O Sacy, São Paulo, 8 jan. 1926.
} 
sintético e fluido. A forma pesada e as grossas linhas, que às vezes se acentuam ainda mais para compor a soberba figura de Pinheiro Machado, são agravadas pelo plano de fundo reticulado e saturado de linhas pretas. O elemento satírico que enfeita o personagem “uma crista de 'Chantecler dos potreiros"”,12 e o seu olhar desconfiado, que parece mais advertir do que aconselhar o consumidor, pode ser um artifício de duplo sentido usado para desmascarar o político: cautela em suas escolhas. O uso da faixa retangular para a entrada e exposição do texto informativo sobre as qualidades do produto e do seu local de venda é um recurso de época, como demonstra a ilustração comercial de K. Lixto, Au Parc Royal [FIG. 170, 1902].

Em Os PAPÁVEIS [FIG. 136], J. Carlos reúne os candidatos à presidência do ano de 1918 e neste exemplo o traço do artista já se afina e flui com naturalidade, apesar dos detalhes figurativos continuarem, o desenho já é um pouco mais sucinto e o plano de fundo praticamente se torna o branco do papel e conta com a moldura retangular de enquadramento da cena, um recurso da época bastante usado nas caricaturas pelos desenhistas do lápis. E a dúvida dos presidenciáveis em beber ou não o vermute que também se verifica no diálogo do texto pode ser uma irônica analogia à escolha por um dos presidenciáveis. O alongamento das figuras, seus gestos e suas fisionomias que compõem a construção imagética do cenário político da época pelo artista, são recursos expressivos e gráficos característicos do gênero caricaturesco.

Também encontramos K. Lixto na caricatura de acontecimentos políticos, anunciando os cigarros York em Os ALIADOS [FIG. 173], e a exemplo de outros artistas do gênero não é a deformação ou exagero que prevalece na cena e sim o humor, porém, uma característica que o diferencia de outros artistas do lápis do período é o humor integrado ao movimento ou aos gestos mais expansivos de seus personagens.

No versificado anúncio A SAÚDE DA MULHER [FIG. 138], com um humor contido por um cínico refinamento, J. Carlos elabora dois momentos cênicos, um para a figura masculina em preto sobre um plano de fundo vermelho, que, pelo seu braço esticado e pela sua mão aumentada, num gesto amplo e afetado, adentra o campo emoldurado com linhas sinuosas do Art Nouveau, as quais continuam no movimento das linhas decorativas dos decotes dos vestidos e nos contornos exagerados dos penteados das figuras femininas. O exagero que esbarra no ridículo desnecessário também se faz presente na cor vermelha que encobre as áreas dos olhos e bocas das figuras femininas e

\footnotetext{
${ }^{12}$ Expressão empregada por Herman Lima, op. cit., v.2, p. 700.
} 
no nariz do homem que se encontra sentado entre elas. Como se trata de um anúncio de medicamento, que só é reconhecido no último verso da longa legenda, a vermelhidão dos rostos femininos - um sinal de saúde - alude a um remédio A SAÚDE DA MULHER, específico "para incommodos de senhoras” que fartamente era anunciado nas revistas da época. Um cenário envolto num clima tipicamente francês, podendo estar associado às manifestações dos brasileiros em Paris que homenageavam a atuação de Rui Barbosa em Haia, como também ser uma alfinetada ao requinte e aos costumes da época, à fragilidade e futilidade feminina em contraposição ao desempenho intelectual do político. Estas três circunstâncias que se mesclam compõem o universo crítico e humorístico de J. Carlos, que, no entanto, estilisticamente ainda não se orienta para o que seria o seu inconfundível estilo de econômicas, finas e graciosas linhas, mas que, por outro lado, já deixou para trás as grossas linhas do portrait-charge de Pinheiro Machado.

Ana Paula Cavalcanti Simioni sugere que Di Cavalcanti inova, ao lado de Ferrignac, a produção na caricatura ao incorporar elementos do Art Nouveau:

O sentido decorativo, combinado com a linha leve e ondulante, é pouco comum nos desenhos dos caricaturistas da época. Ele é freqüente nas ilustrações mas não nas caricaturas, nas quais é preponderante o traço mais pesado e pouco ornamentado de Kalixto ou de Raul Pederneiras.

É por isso que, acreditamos, os desenhos de Di obtiveram uma apreciação positiva por parte dos editores das revistas e de seu público; afinal, o conjunto de seus desenhos revela a elegância,a ironia e o requinte do traço valorizados nos anos de 1910. É como se Di e Ferrignac acrescentassem à caricatura, por meio de recursos como o alongamento circular da linha e o uso de elementos decorativos, algo do requinte das vinhetas e ilustrações do Art Nouveau. ${ }^{13}$

Mesmo se A SAÚDE DA MULHER [FIG. 138] não traz uma data, é possível tentar uma datação a partir de suas referências históricas que apontam para o final do ano de 1907, quando da participação de Rui Barbosa na Segunda Conferência de Paz em Haia. Isso pode ser confirmado no diálogo comprometido que a caricatura tem com os acontecimentos que ocorrem no tempo atual e que no texto se verifica no verso (em tempo presente): “De Haya nos conta um longo telegramma”. Em função disso, aventamos a hipótese que este anúncio comercial seja um dos poucos exemplares do

\footnotetext{
${ }^{13}$ Ana Paula Cavalcanti Simioni, Di Cavalcanti ilustrador: trajetória de um jovem artista gráfico na imprensa (1914-1922), São Paulo: Editora Sumaré, 2002, pp. 85-86.
} 
gênero - “caricatura comercial” - que se apropria das linhas do Art Nouveau. Portanto, sugerimos que o emprego deste estilo na caricatura é anterior à década de 1910, mesmo sendo uma peça direcionada à venda de produtos e que o Art Nouveau seja empregado propositadamente numa cena “à la francesa”. Se as nossas revistas ilustradas utilizavam fartamente a estética francesa dessa tendência em suas ilustrações, contos e até mesmo no emolduramento das fotografias e em seus arranjos, parece-nos plausível que a caricatura em seus várias modalidades, igualmente tenha se encaminhado a essa estilística.

Os exemplos de K. Lixto - suas mulheres estilizadas de [FIGs. 170, 171, 1902] e a imagem de EliXIR MASTRUÇO (1912), ${ }^{14}$ que, embora não assinada, apresenta as mesmas linhas chicoteantes e fitomórficas de outros trabalhos de sua autoria - ou a ilustração comercial que Correia Dias realizou para o xarope TossE... TOSSE... TossE... BROMIL (1915) em que as linhas ondulantes saem do emolduramento e adentram na cena, ${ }^{15}$ permitem estabelecer um diálogo com a afirmação de Ana Paula Cavalcanti Simioni sobre a falta de intencionalidade artística em ilustração de cunho comercial. ${ }^{16}$ Nos exemplos citados, o uso da ornamentação Art Nouveau não parece ser de natureza aleatória, posto que a disposição de cercaduras poderia ser vista como uma operacionalização mental e artística intencional. Não seria possível pensar, pelo menos nesses casos, que o uso de ornamentação Art Nouveau é constituinte da imagem. Em outros casos, talvez seja possível falar numa mecanização do uso de suas linhas, mas não se pode deixar de fazer uma pergunta. Essa mecanização não seria nossa verdadeira aproximação a este estilo, o qual, desde 1906, na França, já havia se distanciado dos seus objetivos iniciais (reunir a arte e a técnica), e desde então percorria o caminho da ornamentação e das artes aplicadas?

Pensando na eficácia desses anúncios, mesmo porque a caricatura não se preocupa com a mimese, constatamos que em todos os casos estudados a identificação do produto está vinculada somente à presença do seu nome no texto ou na imagem. Um procedimento tão bem aceito na época só pode entendido tendo em conta que a propaganda brasileira no período engatinhava, portanto, não havia ainda se submetido

\footnotetext{
${ }^{14}$ EliXIR MAStruço foi publicado na revista Careta, Rio de Janeiro, em 1912. Cf. 100 anos de propaganda, São Paulo: Abril Cultural, 1980, p. 27.

${ }_{15}$ TOSSE... TOSSE... TOSSE... BROMIL encontra-se reproduzido em Aracy Amaral, Artes plásticas na semana de 22, $4^{\mathrm{a}}$ ed., São Paulo: Perspectiva, 1979, p. 82.

${ }^{16}$ Consultar Ana Paula Cavalcanti Simioni, op. cit., p. 64.
} 
aos métodos publicitários racionais e modernos norte-americanos, conforme discutimos no primeiro capítulo. 


\subsubsection{CARICATURISTAS NA ILUSTRAÇÃO COMERCIAL}

LugOLina [FIG. 169, s.d.], talvez seja dentre todas as peças publicitárias criadas por K. Lixto a sua mais conhecida, por fazer com que o leitor co-participe do reclame, através da soletração. Pelo que pudemos verificar, esse anúncio circulou pelos menos até os anos finais da década de 30 e, apesar de suas diversas readaptações, as quatro figuras femininas continuaram fazendo parte da composição, soletrando as quatro sílabas que compõem o nome do medicamento "efficaz de todas as moléstias da pelle”. Em verdade, a versão que nos propusemos a apresentar não é propriamente uma caricatura e sim uma ilustração bem humorada e divertida pela brincadeira equacionada pelo artista. Novamente o recurso da repetição seqüencial está presente, não só na mesma figura feminina que por quatro vezes se repete, mas também nas gestualidades dos lábios que sugerem as sílabas LU-GO-LI-NA. É um reclame enxuto que não pretende corresponder a nenhum padrão estético de beleza e à sua parte visual, agregase um texto informativo do produto. Esse mesmo tipo de humor está representado nas três figuras de ВЕВАм [FIG. 174, 1907], um humor mais solto, mas que também se encontra nos desembaraçados gestos repetidos de seus personagens dançantes. Ainda, neste último exemplo se verifica um diálogo com o cartaz LES GIRARD (1877) de Jules Chéret, pela representação de personagens com costumes de época, pela sinuosidade tortuosa e expressiva das linhas das pernas masculinas da figura do primeiro plano, e pelas interferências da pluma do chapéu e das três garrafas em algumas letras da palavra Bebam. Se o artista francês soube, ao se utilizar das letras, gerar uma continua hierarquia entre as informações, a seu modo K. Lixto procurou fazer o mesmo, quando a ampla abertura de perna de seu personagem principal enquadra os nomes das águas.

Arriscamos a comentar, em função das datas de suas peças comerciais, que $\mathrm{K}$. Lixto já produzia reclames ilustrados decorativos, desde 1902, a exemplo de AU PARC Royal e Cognac Macieira [Figs. 170, 171]. Neles, empregam-se nas imagens femininas as linhas soltas e orgânicas do estilo fin-de-siècle. Esses exemplos revelam a versatilidade do artista.

Mesmo que distantes de suas caricaturas, os “modestos” anúncios 1.000 ConTOS [FIG. 177, 1940] e SÃo JoÃo [FIG. 176, 1943] de K. Lixto, não perderam o humor e pelo período em que foram publicados, indicam que o artista não cedeu às imposições ditadas pela publicidade moderna. Em 1.000 ConTOS, o casal recebe um tratamento 
mais realista, e fica por conta dos seus trajes requintados à época e das poses esnobes o fator cômico. Como curiosidade o círculo no plano de fundo se repetirá em SALUTARIS [FIG. 172, s.d.], peça publicitária que será analisada em INCURSõES PELAS LETRAS E IMAGENS. SÃO JOÃO se apresenta mais descompromissado com a forma e brinca com o movimento que pode ser uma reminiscência das linhas chicoteantes do Art Nouveau, tão exploradas por K. Lixto desde os primeiros anos de 1900. Um dado interessante é a letra $\mathrm{S}$ que se desfaz e se mistura às outras formas, difíceis de serem identificadas, talvez, rojões em pleno ar.

Quanto à produção publicitária comercial de J. Carlos, ela se orienta para a ilustração e não mais para a caricatura, mas é possível encontrar em alguns anúncios como o dos cigarros BELMONT [FIG. 135, s.d.] ${ }^{17}$ e BAL DES FLEURS [FIG. 142, 1935] suas figuras femininas estilizadas ou ainda em INDANTHREN [FIG. 141, 1941], as figuras infantis. Se em BAL DES FLEURS o texto exibe um apelo mais emocional e subjetivo à imaginação do consumidor, em INDANTHREN se evidencia um apelo racional assentado nas características do produto; o decorativismo, que é tão caro ao artista, associa-se à imagem do produto e à sua qualificação, seja na tampa da caixa do pó de arroz, seja nos tecidos expostos à venda. Em oposição a estes, os diversos anúncios da década de 30 para a Caixa Econômica [FIGs. 139, 140, 143, 144] distanciam-se de seus tipos humanos, das linhas finas, vivazes, sensuais e um tanto inquietantes; suas formas são mais pesadas pelas áreas preenchidas com a cor preta e também pelas linhas mais espessas. Os espaços gráficos com textos de caráter informativos são bem cuidados, demonstrando a versatilidade artística de J. Carlos, como igualmente sua atualização profissional frente às exigências do mercado publicitário.

Ponto em comum entre BELMONT, BAL DES FLEURS e AindA TENHO TEMPO [FIG. 143, 1935], este último um anúncio da Caixa Econômica, é a colocação deslocada da figura humana à direita ou à esquerda do campo visual em conjunção com uma diagonal. J. Carlos serve-se com propriedade das várias linhas e cortes em diagonais para compor a cena, o que pode ser observado também em A CigARRA E A FORMIGA [FIG. 144, 1935], que inclui a arquitetura Art Déco pelo predomínio das formas retilíneas nas fachadas dos edifícios, pela esquematização cubista e pela sua geometrização escalonada, um sincretismo brasileiro, tal qual presenciamos na

\footnotetext{
${ }^{17}$ Consultar Nelson Varón Cadena, Brasil - 100 anos de propaganda, São Paulo: Edições
} Referência, 2001, p.81. O autor atribui esse anúncio à J. Carlos. 
verticalização do edifício no anúncio comercial do Cimento PoRTLAND [Fig. 126, 1931] do artista publicitário J. G. Villin. Ainda, em A CigARRA E A FORMIGA, notam-se a reunião e a superposição de distintos elementos tipográficos (letras, sinais e números) que derivam, sobretudo, do triângulo eqüilátero e do círculo. Semelhantes recursos tipográficos são empregados em PENHOREs [FIG. 139, s.d.], que se repetem na cena em suas partes superior e inferior, mas, o artista inverte o preenchimento das barras e números, criando uma descontinuidade visual.

Por fim, Umberto Della Latta que por anos criou anúncios comerciais para os chocolates Falchi, brinca com o mito de Salomé, tema bastante recorrente desde o final do século XIX, recriando uma versão em que o motivo da perda da cabeça é o CHOCOLATE FALChI O MELHOR DO BRASIL [FIG. 167, 1917]. Nesta peça publicitária, o círculo com densos motivos decorativos no plano secundário, um recurso de época, se faz presente para sustentar visualmente a imagem da figura feminina, sendo que as muitas e pouco delicadas linhas filiformes dos véus da saia de Salomé sofrem interferência das densas linhas pretas desenhadas pela espada, artifício que define tanto o movimento da cena como o nome do produto. Em outro anúncio do chocolate Falchi [FIG. 210, s.d.], o artista também empregou a forma circular decorada, não só para enquadrar a cena de tema oriental, mas também para contrapor às circunferências das sombrinhas japonesas do primeiro plano. ${ }^{18}$

Chamamos atenção para as ilustrações de Di Cavalcanti publicadas em O Pirralho, InVERno e O MINISTRO DA GUERRA DISPENSOU O ARDOR PATRIÓTICO DA BRIOSA, pela presença do enquadramento circular, total ou parcial, de seus personagens. $^{19}$

Em continuidade, a produção publicitária de Umberto Della Latta encaminha-se para um tratamento mais realista da imagem feminina e de seus produtos de consumo, seja empregando o estereótipo da mulher sedutora em FALCHI O CHOCOLATE PREFERIDO [FIG. 163, 1935] e em FRUNA, ${ }^{20}$ ou da mulher envolvente e suave em ÁGUA DE COLÔNIA ADORAÇão [FIG. 164, 1936]. ${ }^{21}$ Nos dois casos, o artista já se encontra distante do humor de seus trabalhos anteriores.

\footnotetext{
${ }^{18}$ O anúncio foi publicado nas páginas do Programma Oficial do Teatro Municipal, s.d. Arquivo da autora.

${ }^{19}$ As ilustrações mencionadas foram publicadas em O Pirralho, São Paulo, (235), 28 abr. 1917.

${ }^{20}$ FrUNA foi publicado em Eu sei tudo, Rio de janeiro, (112): 103, jan. 1935.

${ }^{21}$ Em suas pesquisas acerca da relação entre arte e publicidade, Juan Carlos Pérez Gauli, concluiu que os estereótipos publicitários são herdeiros dos artísticos. Para um aprofundamento
} 
Pelo que recuperamos das peças publicitárias, a tríade K. Lixto, Voltolino e J. Carlos é a que mais apropriadamente exemplifica o uso mesmo da caricatura em suas variantes na publicidade comercial da época. Considerando a morte precoce de Voltolino, foi K. Lixto, entre os caricaturistas que continuaram produzindo trabalhos comerciais publicitários, aquele que mais guardou proximidade com o engraçado e o humor leve dos anos 20. Por sua vez, J. Carlos experimentou mais e se dedicou aos projetos gráficos. Arriscamos-nos a afirmar, sem pieguices, que ele foi um artista completo, no entanto, talvez, no enfoque desse nosso estudo, menos caricaturista e mais ilustrador. Na publicidade comercial, não impôs seus tipos femininos, utilizou-se sim deles em alguns momentos, mas soube transitar por outras criações artistas e gráficas que a publicidade daqueles anos passou a requerer. 


\subsubsection{HERDEIROS DO TRAÇO}

Se a presença dos caricaturistas nos anúncios comerciais diminui e se conforma ao crescente uso da fotografia e à profissionalização do meio publicitário, seguem nessa produção os ilustradores que podem ser aceitos como uma linhagem descendente da geração de artistas do lápis que tratamos no item anterior; alguns deles também com passagens na caricatura, a exemplo de Seth, Acqua, Romano e Alvarus. Dentre estes, destacam-se os dois primeiros pelo expressivo número de peças publicitárias produzidas, e Orestes Acquarone complementa o grupo. Infelizmente, no catálogo de imagens não foi possível apresentar o conjunto iconográfico desses artistas em seu todo, assim, fizemos opções já justificadas na introdução da tese.

Em termos formais, suas produções não são inovadoras. Elas sempre se ocupam de um espaço de representação e não de percepção e do uso do desenho a traço que facilita a legibilidade da imagem. Porém, destaca-se o domínio do metiê, pela variedade de escolhas e soluções técnicas empregadas.

O ilustrador Alberto Lima confere em ARTIGOS PARA HoMENS [FIG. 111, 1936] uma organização espacial dos elementos formais e gráficos que difere de outros anúncios da época. As peças que compõem o guarda-roupa masculino são delicadas formas geometrizadas construídas a partir do círculo, retângulo e triângulo, que se ordenam como num mostruário. Algumas delas já haviam sido empregadas no anúncio AlfaiATARIA sob Medida [FIG. 112, 1935] do ano anterior, no qual a composição da cena é bem mais tradicional. ARTIGOS PARA HOMENS demonstra uma maior versatilidade na combinação de tipos e seus preenchimentos, ora mais pesados, a exemplo da palavra "homens” e “Casa José Silva”, sendo que nesta última, o artista extrapola ao encobrir a parte inferior da letra J que faz parte do nome da casa comercial, por outro lado, lança mão da alternância do preto no branco e vice-versa. Não podemos esquecer que os anos 30 foram o receptáculo de um acentuado interesse dos nossos artistas pela tipografia, momento também em que nos posicionávamos sobre a nossa débil produção cartazística.

Paim Vieira também realizou alguns trabalhos publicitários para casas de modas masculinas e femininas. Apesar de serem da metade da década de 20, deles nos utilizaremos para demonstrar quão distintos são dos de Alberto Lima, tendo em conta não necessariamente e apenas suas individualidades artísticas, mas sim os veículos em 
que publicaram seus anúncios. Enquanto Artigos para Homens foi publicado na revista O Cruzeiro, os de Paim Vieira saíram nas páginas de Ariel.

Do ano de 1924, são alguns exemplos de Paim Vieira: MANTEAuX [FIG. 35], Modas, [Fig. 36], CASA Ramos Alfaiataria [Fig. 37] e Modas de InVERno [Fig. 39]. Todos esses anúncios são xilogravuras com figuras femininas e masculinas estilizadas e, com exceção de CASA RAmos AlfaiATARIA, os trajes femininos abusam dos elementos decorativos, sendo, em verdade, os que se destacam nas cenas. Comparando uma ilustração do artista, ECCE HOMO [FIG. 38, 1924], com o anúncio da alfaiataria, constatamos serem os dois muito próximos em termos estilísticos, por empregarem a mesma técnica de gravura, as mesmas linhas brancas que constroem “persianas horizontais" no plano de fundo e o mesmo clima tenebroso impresso tanto nas cenas quanto nas figuras masculinas em perfil, clima este que nós parece inapropriado para venda de roupas, o que para a época também deveria causar estranhamento. Assim, propomos que a revista paulista Ariel, da qual Paim Vieira foi ilustrador, foi-lhe um campo de experimentação artística. Este fato dificilmente ocorreria, em meados dos anos trinta quando a publicidade brasileira vivenciava novos rumos, numa revista com o perfil de O Cruzeiro; por outro lado, considerando Paim Vieira um artista que não descende do desenho a traço, entendemos que sua produção publicitária caminhe lado a lado da sua produção independente, não determinando linhas fronteiriças.

Estendemos essas observações também aos anúncios dos anos 30 que Vicente do Rego Monteiro publicou em revistas da cidade de Recife. São eles GoIABADA PeIXE [FIG. 52, 1937], GRAVATÁ [FIG. 50, 1936] e o anúncio xilogravado para a GoIABADA PeiXe SEMPRe a MelHOR [Fig. 49, 1939]. Neste caso, como no de Paim Vieira e também como veremos em Flávio de Carvalho, Rego Monteiro teve participação ativa nos periódicos, pois foi diretor da revista Renovação e co-dirigente de Fronteiras. ${ }^{22}$

A distância estilística que separa os anúncios de Paim Viera criados para a casa de modas Elisa Giacconne [FIGS. 34, 35, 36, 39] e os de Lanza, ${ }^{23}$ como EsTAÇÃo LYRICA [FIG. 110, 1924], nos faz pensar se existiam critérios por parte dos anunciantes

${ }^{22}$ Esses anúncios foram respectivamente publicados em: Fronteiras, Recife, (21): 30, jan. 1937; Fronteiras, Recife, (18): 15, out. 1936; Renovação: Órgão de Ação Educacional Proletária, Recife (4): IV capa, dez. 1939. Sobre a participação de Rego Monteiro nas revistas mencionadas, consultar Walter Zanini, Vicente do Rego Monteiro artista e poeta 1899-1970, São Paulo: Empresa das Artes: Marigo Editora, 1997, pp. 15-16.

${ }^{23}$ Lanza substitui Paim Viera quando este deixou de ilustrar as páginas de Ariel, após o seu número 12, em 1924. 
em aprovar ou não as publicidades de seus produtos promovidos em Ariel. ${ }^{24}$ Apesar de os dois artistas investirem na estilização formal, os de Paim são carregados, enquanto os de Lanza, correspondem ao gosto da época, pois são construídos com linhas finas e curvas delicadamente definidas, com pouco elementos decorativos e bem dentro de um clima de suavidade e feminilidade estereotipadas. Em ambos a informação sobre o produto está na palavra e não na imagem.

Retomando os ilustradores do Rio de Janeiro, na linha de uma visualidade esquemática próxima de os Artigos para Homens [FIG. 111] de Aberto Lima, podemos considerar o anúncio O MELHOR COMBUSTÍVEL E O MELHOR FOGÃO [FIG. 151, 1936] de Romano. Se, porém, no primeiro havia uma acumulação de elementos visuais, que não dispersavam a apreensão da cena, no caso de Romano ocorre uma acumulação dispersiva e dinâmica, em função das duas setas que impõem ao leitor um percurso visual a partir do centro da imagem que contém a marca do produto. O uso da repetição ocorre nos quatro cantos da moldura e nas palavras "gaz" e "o melhor”. Se, na primeira imagem, sentimo-nos diante de um desenho ingênuo, que ainda não incorporou os clichês publicitários, na segunda eles já se tornam visíveis, porém serão os trabalhos publicitários de Orestes Acquarone os melhores exemplos dessa absorção.

Em TOSSE? BROMIL [FIG. 121, 1924/1929?] figuram dois balões que estão sendo enchidos de ar por duas crianças. E tal qual o nome do xarope que da pergunta passa à resposta, a imagem, em sua construção seqüencial, indaga sobre a escolha do observador, num percurso visual que vai do primeiro ao segundo plano. Tosse ou Bromil? Força dos pulmões, resistência, competitividade, alta capacidade respiratória e a cor vermelha, são atributos analógicos aplicáveis aos efeitos benéficos do medicamento e que induzem o leitor a acreditar que o primeiro menino, com a bola vermelha e maior, a do Bromil, venceu a tosse. Um outro anúncio do mesmo xarope [FIG. 122, 1929] associa-se ao símbolo da cidade do Rio de Janeiro, o Pão de Açúcar. Monumento natural hierático, envolto por ar puro, TOSSE? BROMIL está no seu cume e novamente temos o uso do clichê apontando para o máximo de qualidade do medicamento. Essa associação com o Pão de Açúcar, desta vez como conforto e realização dos desejos, encontra-se num anúncio de Monsã para a LOTERIA DO ESTADO DE MiNAS GERAIS [FIG. 57, 1939].

\footnotetext{
${ }^{24}$ Relembrando, os dois anúncios de Guilherme de Almeida, divulgados nas páginas de Klaxon foram recusados pelos anunciantes.
} 
Em grande parte de suas peças publicitárias, Orestes Acquarone determina para o eixo do olhar a construção axial, assim ocorre também em NUTRION [FIG. 123, 1929], que pelo dinamismo da cena e pelo corpo musculoso da figura masculina comprova a eficácia do medicamento.

Novamente o recurso da repetição é empregado, mas desta vez como conseqüência de um acúmulo. Numa imagem seqüencial ascendente, o percurso do olhar de baixo para cima dá conta do previsível conteúdo visual de o GRANDE SORTEIO DE SÃo JoÃo [FIG. 120, 1933]. Salvo o emprego de tantos chavões da linguagem publicitária da época, que o forçam a adotar recursos formais astuciosos, Orestes Acquarone tem seu merecimento como ilustrador pela sua maestria técnica, a destacar o desenho a traço. ${ }^{25} \mathrm{E}$, ao seu lado se coloca Seth, que muito produziu entre as décadas de 1920 e anos finais da seguinte. Se seus anúncios comerciais não são inovadores, eles empregaram distintos procedimentos técnicos que lhe permitiram maiores diversidades ilustrativas.

Sempre apoiados na representação figurativa, os anúncios de Seth transitam pelo humor [FIG. 154, 1939], haja vista ter-se desenvolvido por meio da caricatura, pelas imagens repetitivas, pelo desenho figurativo do produto associado a um texto argumentativo como em ÁGUA INGLESA GRANADO [FIG. 155, 1929], pelo emprego das analogias em Phosphovitamina [FIG. 157, 1930], entre tantos outros exemplos que constituem sua vasta produção como ilustrador de peças publicitárias.

O ilustrador Acqua, também muito se exercitou no desenho a traço [FIGs. 116, 117], ora com delicadas linhas próximas das de J. Carlos, ora com hachuras e reticulas que remetem aos trabalhos ilustrativos de Orestes Acquarone.

Do exposto, indagamos se seriam os ilustradores e artistas da cidade de São Paulo mais livres em suas criações comerciais do que os do Rio de Janeiro. A pesquisa iconográfica identificou dois eixos abarcantes da produção de peças publicitárias, que vinculam-se às cidades de São Paulo e Rio de Janeiro, ${ }^{26}$ em função de seus circuitos

${ }^{25}$ Em relação ao desenho a traço, nos explica Cássio Loredano: "Por causa do sistema de reprodução dos desenhos, que era o da 'cor indicada', ou 'cor aplicada', dá no mesmo. E que consistia em o desenhista fazer o 'traço', isto é, tudo o que é para sair em preto na revista, e mandar para a oficina confeccionar o clichê; feito o quê, o original 'subia' de volta para o desenhista indicar a(s) cor (es) com pinceladas muito lavadas sobre o 'traço'; que 'descia' outra vez para o chefe da oficina determinar a aplicação do que o artista indicara, mandando fazer outro clichê para cada cor”. Cássio Loredano, O bonde e a linha: um perfil de J. Carlos, São Paulo: Capivara, 2002, p. 60.

${ }^{26}$ Incluímos nessa informação o deslocamento de artistas de outros estados brasileiros ao Rio de Janeiro. Essa nossa constatação foi elaborada a partir do contato direto com as diversas revistas 
artístico e cultural, destacando o papel da imprensa escrita, cabe-nos, porém, diferenciálos, pois cada qual tem suas particularidades.

A produção carioca, quando de autoria conhecida, é quantitativamente volumosa e continua, até aproximadamente meados da década de 30, nas mãos dos desenhistas do lápis e se apresenta com características formais mais conservadoras, decorrentes, talvez do exercício do desenho, do chamado desenho a traço, que foi amplamente empregado pelos conhecidos "ex-caricaturistas" e ilustradores; dessas conclusões excluímos o profissional J. Carlos, pela sua desenvoltura artística publicitária. Julgamos que os artistas em São Paulo puderam se colocar com mais liberdade num meio menos competitivo e menos formalizado pelo desenho, num ambiente ávido de novos profissionais para trabalharem na imprensa. Assim, vale citar Ana Paula Simioni, que assinala

Os dois critérios para a entrada no campo das artes gráficas eram a capacitação técnica e as indicações pessoais, o apadrinhamento. Por vezes esses dois trunfos vêm combinados, outras vezes apenas um deles bastava para que o ingressante conseguisse o que almejava. O que parece certo é que no Rio de Janeiro havia maior exigência do primeiro atributo, ao passo que em São Paulo o segundo critério parecia ser mais determinante, isso porque no Rio não havia oferta disponível de postos como em São Paulo e, além desse fator, o nível de capacitação dos pretendentes era maior em virtude da oferta de instituições de ensino artístico. $^{27}$

Contudo, devemos ter em conta a proposta editorial e a circulação das revistas em que se encontram as peças publicitárias dos artistas estudados, pois, enquanto os periódicos cariocas dispunham de um maior número na linha de variedades, que são veículos com boa aceitação e divulgação, dirigidos a um público leitor "menos exigente” que bem compreende o desenho gráfico de humor e a ilustração comerciais, as de São Paulo, em menor número, eram direcionados às elites por serem da área literária e artística em geral, a exemplo de Ariel e Klaxon, que em termos estéticos arejavam os reclames da época. Nesse universo, a revista paulista de variedades A Cigarra constitui uma exceção, pois nela localizamos poucos anúncios assinados por

pesquisadas. Também é oportuno mencionar que, entre as décadas de 1910-1920, 70,3\% dos profissionais do desenho se concentravam no Rio de Janeiro enquanto que São Paulo contava com 7,4\%. Essas cifras foram levantadas por Ana Paula Cavalcanti Simioni, op. cit., p. 66.

${ }^{27}$ Idem, p. 75. 
artistas visuais ou que pudessem ser identificados mesmo sem autoria. E uma das características de A Cigarra era o seu investimento na fotografia.

Assim é que os artistas cariocas submeteram suas expressividades artísticas a um cerceamento, pois estavam mais próximos das exigências do mercado; por sua vez, os artistas de São Paulo não sendo os verdadeiros herdeiros do traço, e nessa discussão incluímos Vicente do Rego Monteiro, não estavam amarrados por compromissos com a grande imprensa, daí terem maior flexibilidade para criarem suas peças publicitárias, mesmo porque trabalhavam para seus pares ou seus afins. Ainda, muitos dos ilustradores que atuaram no Rio de Janeiro tiveram que se adaptar a partir dos anos 30 e, sobretudo na década de 40, às exigências impostas pela publicidade racional que invadia as principais cidades brasileiras. Contudo, não conseguimos obter informações até quando esses profissionais do lápis se mantiveram em atividade nessa produção, devendo-se considerar também que muitos deles vieram a falecer entre 1940-1950.

Os fatores apresentados nos levam a concluir que a invasão da fotografia, a profissionalização do meio publicitário e o declínio das revistas culturais sufocaram as livres passagens de nossos artistas plásticos e gráficos pela publicidade comercial e desagregaram o grupo de profissionais engajados nessa produção artística. 


\subsection{INCURSÕES PELAS LETRAS E IMAGENS}

Dentre as poucas peças publicitárias comerciais localizadas, nas quais o emprego de letras e palavras traz inovação gráfica para a época, destaca-se o anúncio do CoMA LACTA [FIG. 26, 1922], que, ao utilizar duas únicas palavras (coma Lacta) e ocupar a página inteira de uma revista, aproxima-se das características do cartaz, ou seja, daquelas resultantes da possibilidade de legibilidade à distância, da simplicidade e da unicidade de argumentação. Ele corresponde ainda à máxima "se o anúncio argumenta, faz conhecer o produto, por sua vez o cartaz faz conhecer o seu nome, a marca”. ${ }^{28}$ No entanto, esse interessante exemplo, que não pode deixar de ser aqui apresentado, não foi concebido por um artista visual e sim por um poeta, Guilherme de Almeida, o qual também criou com a tesoura e a goma-arábica um anúncio para o GUARANÁ ESPUMANTE [FIG. 27, 1922]. ${ }^{29}$

Guilherme de Almeida, talvez inspirado nos exemplos inovadores da tipografia futurista ou mesmo nas aventuras de seus congêneres franceses, Stéphane Mallarmé e Guillaume Apollinaire, ${ }^{30}$ além de romper com o espaço poético tradicional que determina uma leitura horizontal e direcionada, soube transpor o arranjo hierárquico das palavras, alterando o tamanho dos tipos e os próprios tipos, recombinando-os na marca do produto que ao mesmo tempo se torna o sujeito único e principal do anúncio, do mesmo modo que as parole in libertà as quais definitivamente substituem a imagem. A imagem é um nome.

Comparando COMA LACTA com outras propagandas do gênero concebidas no período, Chocolate Falchi de Umberto Della Latta [FIG. 168, 1921], encontramos nesta em particular, uma solução formal bastante comum pelo uso da imagem que se

28 Sobre as características do cartaz, consultar Abraham Moles, O cartaz, São Paulo: Perspectiva, 1987, p. 47. Quanto à máxima citada, seu aparecimento foi na revista Vendre, Paris, mar. 1927, cf Réjane Bargiel, "Évolution de l'affichage”, in V. A., Quand l'affiche faisait de la réclame! L'affiche française de 1920 à 1940, Paris: Edition de la Reúnion des Musées Nationaux, 1991, p. 25.

${ }^{29}$ Relembramos que tanto o anúncio do COMA LACTA quanto o do GUARANÁ EsPUMANTE foram publicados na revista Klaxon, respectivamente em maio e junho de 1922.

${ }^{30}$ Referimos-nos, particularmente aos poemas Un coup de dés (1897) e Il pleut (1914), que romperam com as convenções tipográficas da época. É curioso notar que Guilherme de Almeida, tenha concebido esse reclame, pois naquele momento escrevia poesias de viés simbolista, enquanto Mario de Andrade e Oswald de Andrade optavam pelo verso livre, o que os coloca em proximidade com o futurismo italiano e, portanto, em diálogo direto com COMA LACTA. 
repete horizontalmente promovendo a leitura da marca do produto. E, diferentemente da construção de Guilherme de Almeida, a letra não toma o lugar da imagem, mas sim a ela se articula para efetivar a mensagem. Outros exemplos seriam os já comentados anúncios do chocolate Lacta criados por Voltolino que se inserem nas tipologias da caricatura.

Respeitando as diferenças de ambiente cultural e as proposições artísticas vanguardistas européias, certamente as nossas experiências tipográficas não são radicais, e sim bastante moderadas, mas COMA LACTA pode ser “comparado” à capa do número 3 da revista dadaísta Mécano (1923), uma criação de Theo van Doesburg, que também se utiliza de palavras dispostas ao longo da borda do papel nos sentidos vertical e horizontal, tal como a palavra coma. Por sua vez, a palavra Lacta em suas variantes derivadas dos preenchimentos de tipos, que lhe conferem pesos distintos, e pelas suas colocações em diagonais, promove um dinamismo visual que remete aos efeitos dos letreiros luminosos, e, por outro lado não deixa de aludir visualmente ao som de buzinas. $^{31}$

Apesar de não ser um exemplo com fins publicitários, a já citada capa do livro Cartazes [FIG. 28, 1928], executada por Arnaldo Barbosa, apresenta-se em diálogo com o anúncio de Guilherme de Almeida, seja pela investida no uso das palavras, seja pelo movimento impresso pelas colagens retangulares de diversos reclames da época e que operam visualmente como faixas de letreiros. ${ }^{32}$

Além de se afinar ao projeto ideológico e modernista da revista Klaxon, podemos ainda pensar que a ausência de traço autoral de COMA LACTA, determinada não pela ausência de assinatura, mas sim pela sua própria concepção formal destituída de detalhes e ornamentos, aproxima-se, ainda que muito provavelmente não tenha sido a intenção de seu criador, dos posicionamentos que ocorriam no plano europeu e que viriam a se adensar a partir de meados dos anos 1920 a favor de uma arte publicitária que fosse assegurada por suas especificidades e não por exigências estéticas individualistas. E será por meio da tipografia que a arte publicitária receberá sua maior contribuição, num primeiro momento com as tendências construtivistas ${ }^{33}$ vindo a se potencializar posteriormente a partir de sua associação com a fotografia (typo-photo).

\footnotetext{
${ }^{31}$ Tanto Theo van Doesburg quanto Kurt Schwitters exploravam a tipografia para criar figuras sonoras.

${ }^{32}$ Paulo Mendes de Almeida, Cartazes, São Paulo: Livraria Liberdade, 1928.

${ }^{33}$ Eckhard Neumann, "Le graphisme fonctionnel: entre les nouvelles conceptions artistiques et les besoins de la société industrielle”, in Pontus Hulten (org.), Paris, Berlin: rapports et
} 
Se o propósito do Futurismo frente à publicidade era levar às ruas a sua estética, eles o conseguiram e foram ainda mais longe, pois a arte gráfica e a publicidade internacionais absorveram as inovações do movimento italiano, como explica Claudia Salaris

Lançando as "palavras em liberdade” Marinetti considerou a necessidade de empreender uma "revolução tipográfica", caracterizada por uma lettrage viva, livre e expressiva, e por uma nova concepção do espaço na composição gráfica, que desordenasse completamente as noções tradicionais de harmonia, elegância e simetria. O grafismo futurista, elementar e sintético, conquistou um novo estatuto ter o seu valor plástico.

Suas inovações foram colocadas em evidência pelo editor e tipógrafo Carlo Frassinelli que, em um estudo sobre a "revolução gráfica”, as situa como a fonte de todas as pesquisas modernas, desde a "tipografia elementar" russa dos anos vinte aos trabalhos dos grafistas modernos na Alemanha, Áustria, Hungria e Tchecoslováquia. ${ }^{34}$

A nosso entender, a peça publicitária de Guilherme de Almeida, apesar de única bem pode ser aceita como uma experiência que "antecedeu" e dialogou, em nosso acanhado meio artístico e publicitário, com os objetivos do reclame moderno da década, a exemplo do que escreveu El Lissitzky no número especial de Typografische Mitteilungen (1925). Para este, o traço pessoal do artista não tem nenhuma importância, visto que tipografia deve se subordinar inteiramente à função e transmitir com clareza a informação. Por sua vez Aracy Amaral, comenta que esse anúncio

transcende sua condição publicitária. Projetado e executado em termos espaciais, com grande economia de meios, pode ser apontado como um poema pré-concreto, ou como um poema-carimbo semelhante ao composto por Oswald de Andrade no seu diário de garçonniére, intitulado O Perfeito Cozinheiro das Almas dêste Mundo. ${ }^{35}$

A xilogravura do anúncio comercial do GUARANÁ EsPUMANTE, que igualmente ocupa uma página inteira da revista Klaxon, é uma intrigante figura de homem,

contrastes france-allemagne, 1900-1933 art, architecture, graphisme, littérature, objets industriels, cinéma, théâtre, musique, Paris: Centre National d'Art et de Culture Georges Pompidou, 1978, p. 402.

${ }^{34}$ Claudia Salaris, "Le futurisme et la publicité", in Centre Georges Pompidou, Art \& Pub: art et publicité 1890-1990, Paris: Éditions du Centre Georges Pompidou, 1990, pp. 185-186. A palavra lettrage corresponde a lettering = forma desenhada.

35 Apud Mário da Silva Brito (introd.), Klaxon: mensageiro de arte moderna, São Paulo: Livraria Martins Editora, 1972, s.p. Edição fac-símile. 
construída com traços toscos de derivação expressionista, que cogita os nomes das bebidas que lhe vêem à mente. Elas nos são apresentadas por meio de faixas brancas com nomes escritos à mão e riscados, com exceção da bebida eleita. As duas peças publicitárias criadas por Guilherme de Almeida guardam entre si certa semelhança, seja pelo dinamismo visual conferido pelo uso das palavras dispostas na diagonal, seja pela moldura, que no caso da xilogravura foi construída com áreas pretas e localizada à esquerda do plano de fundo da imagem, e no outro exemplo, com as palavras coma.

O anúncio SALUTARIS [FIG. 172] de K. Lixto também emprega a sobreposição de elementos tipográficos e nos remete ao cartaz comercial de Paul Colin: PAS D’R ... PAS D’ APPÉTIT. PRENEZ L’R APERITIF SUPÉRIEUR. GARÇON UN R (1933). Na versão brasileira, vemos no fundo da composição, um círculo central na cor vermelha, sobreposto pela letra $S$, que por sua vez é sobreposta pela imagem de um garçom que, ao tentar abrir uma garrafa, cria uma cena engraçada. Se o nome da bebida Salutaris tem em seu ponto mediano a letra $\mathrm{T}$ que determina uma medida eqüidistante das extremidades (cada qual ocupada pela letra S), no plano vertical, o seu ponto central também divide a imagem e a letra $\mathbf{S}$ em duas partes. A letra $\mathbf{S}$ evidentemente se refere ao nome da "melhor água de mesa”. As cores chapadas vermelha e preta associadas ao branco do papel, bem como o esquema compositivo com círculos e letras, nos fazem lembrar as lições tipográficas da Bauhaus, o que não deixa de ser incomum na produção de um artista que descende da caricatura. Pelo nosso levantamento iconográfico, o estilo artístico adotado por K. Lixto em SALUTARIS parece ser um caso isolado em sua obra.

As descompromissadas experiências tipográficas de Flávio de Carvalho não possuem vínculo com as especificidades do cartaz, pois a legibilidade tipográfica requerida para tal está comprometida mesmo para a leitura de perto, como reclama para si qualquer espécie de anúncio, mas seus trabalhos não deixam de apresentar particularidades que surpreendem e contribuem para a propaganda comercial da época. Nesse sentido, ilustra nossa observação UltRA Moderno [FIG. 47, 1930], no qual a opção pela escrita manual peca pela falta de uma comunicação clara devido às palavras ondulantes que compõem o texto interferirem na leitura, ao sugerirem visualmente uma interpenetração das mesmas, o que vem a se acentuar pelo preenchimento em negrito do nome do artista. Apesar disso, essa peça não deixa de ser interessante, seja por sua horizontalidade irregular e pelo emprego único de elementos tipográficos, seja como um 
elemento questionador e diferencial desse tipo de propaganda, que geralmente figurava nos indicadores profissionais padronizados pela imprensa. ${ }^{36}$

Um parêntese. Tanto os anúncios de Guilherme de Almeida como os de Flávio de Carvalho eram divulgados em revistas artísticas e culturais de circuito restrito, como já observamos em outro momento, as quais muitas vezes estavam sob suas direções ou de amigos. Este fato é importante, pois além dos artistas se alinharem ao perfil ideológico e estético dos periódicos, eles dispunham de liberdade e respaldo para as suas experimentações artísticas.

Ainda dentro da perspectiva analítica anterior, o anúncio publicado na revista Rumo [FIG. 48, 1933] não apresenta uma bem sucedida organização interna, devido à confusão visual proporcionada pela distribuição das palavras que interfere e dificulta a compreensão da mensagem. Levando-se em conta a geometrização das formas que procuram dar representatividade às suas diversas atividades profissionais (engenheiro, arquiteto, escultor e decorador) e o tipo manual usado no texto, nos arriscarmos a dizer que o elemento tipográfico não se subordina à função. Em contrapartida, é em A VOLÚPIA DA FORMA [FIG. 43, 1930] que Flávio de Carvalho melhor integra imagem e tipos, pelo diálogo de caráter expressivo e livre entre as curvas do corpo e as ondulações dos cabelos da figura feminina e as letras. Podemos agregar a esse último exemplo o anúncio comercial xilogravado de Vicente do Rego Monteiro, GoiABADA PEIXE SEMPRE A MELHOR [FIG. 49], no que tange ao uso da frase "sempre a melhor" escrita livremente e que acompanha a linha branca e sinuosa da imagem.

Apesar de ainda se ater à representação do produto e não pensar o espaço integralmente de modo perceptivo, a seqüência repetitiva e linear de TROPICALUMINIO [FIG. 45,1939], própria das lâminas metálicas da cortina, tem sua continuidade na cadeia ordenada e lógica do longo texto argumentativo à sua direita, que linha por linha e com letras minúsculas joga com o máximo de informação sobre o produto anunciado.

Se o cartão comercial A VACA [FIG. 46,1945], num primeiro momento impõe ao leitor um acúmulo de dados, o seu cuidadoso exame revela que Flávio de Carvalho, ao tomar a liberdade de combinar em espaços delimitados vários tipos gráficos com ou sem preenchimento, promovendo leituras horizontais e verticais, conferiu uma disposição interna ordenada, principalmente pela disposição simétrica das informações e pela

\footnotetext{
${ }^{36}$ Remetemos o leitor à página 89 desta tese, onde se encontra um modelo de Indicador profissional.
} 
imagem da vaca, ressaltada pelos preenchimentos em negrito, estabelecendo uma relação de equilíbrio com a palavra A VACA em tamanho aumentado.

O apelo para o “ultra moderno” das peças publicitárias de Flávio de Carvalho é em sua maioria da década de 1930, e elas bem poderiam ter-se lançado com mais profundidade nas experiências tipográficas da Bauhaus. Arriscamos esse comentário devido à possibilidade do artista ter travado contato com o arquiteto Alexandre Altberg, idealizador da revista base. Pedro Moreira, ao historiografar esse periódico confirma nossa hipótese:

Alexandre Altberg, acostumado às dezenas de publicações na Alemanha, decide iniciar em 1933 uma revista própria, que recebe o nome de "base - revista de arte, técnica e pensamento”. [...] Ao contrário do que consta em algumas fontes da literatura sobre o Modernismo, foi Alexandre Altberg o principal responsável pela pioneira iniciativa da Revista base. Ele foi ao mesmo tempo seu editor, financiador, designer gráfico, ilustrador, autor, "curador" de textos e - por motivo de redução de custos - até mesmo tipógrafo.

Montando letra por letra todas as matérias e anúncios, Alexandre usa esta oportunidade para impulsionar a revitalização das Artes Gráficas daquele período: utilizando-se somente da letra minúscula, ele literalmente "constrói” blocos de texto, exagerando nos espaçamentos, quando necessário. Os textos são apresentados com, alternadamente, dois tipos de letra, em interação com barras e imagens em preto e branco. Por motivo de custos, ele utiliza uma só cor primária contrastante para confeccionar a capa e acentuar conteúdos. Seu procedimento vai além daquele que havia aprendido das revistas modernas alemãs dos anos 20 e dos “Bauhausbücher”, livros coordenados por Lászlo Moholy-Nágy. Sua Arte Gráfica não busca ser expressiva nem causar o choque, ela é conseqüentemente 'moderna' no sentido estético e funcional.

O intuito de Altberg ia muito além de publicar uma simples revista de Arquitetura. Como cosmopolita, ele deixa claro seu esforço pela atualização da produção brasileira e sua inserção num contexto internacionalizado, e procura transmitir aos leitores uma visão integral da Arquitetura como fenômeno cultural, em relação orgânica com as outras Artes, especialmente com as Artes Plásticas. Esta última posição já vinha há muito sendo proclamada em suas diversas facetas e nuances, seja por Sullivan e Wright, Peter Behrens, Walter Gropius ou Le Corbusier. Promovido já em meados dos anos 20 pelo próprio Warchavchik, este ideário veio pelas mãos de Lucio Costa a tornar-se um ponto marcante na produção carioca e brasileira.

Utilizando-se dos contatos obtidos através da PRÓ-ARTE, Altberg convida diversos autores dos círculos modernistas a contribuir à revista, como Quirino da Silva, Octávio de Faria ou H.A. Reiner. No primeiro número, bem comenta Lélia Coelho Frota: "o artigo que segue à abertura editorial (de autoria de Altberg), assinado m.d.a. (Mário de Andrade) constitui na verdade a proposta conceitual da revista, que vale a pena 
citar mais extensamente, pelo seu ineditismo: "Hoje a Arte quer penetrar nos escaninhos mais ásperos da vida coletiva; entra nos laboratórios, nos hospitais, nas fábricas, nunca se fez tanta arte no mundo, e jamais os problemas dela, não apenas puramente de ordem estética, mas problemas científicos, tecnológicos, étnicos, sociológicos, preocupam tanto a humanidade". 'Encontramos na base artigos sobre literatura, música, ballet, fotografia, lançamentos, textos críticos diversos. Dentre os anúncios de exposições de Artes Plásticas, encontramos as de Di Cavalcanti, Portinari, Segall, ou mesmo de Käthe Kollwitz. [...] idênticas fossem tomadas por outros sindicatos, consolidando a primeira edição de base pôde ser publicada em agosto de 1933 graças ao apoio da empresa de Falk Altberg (Altberg Import-Export, distribuidores de artigos para fumantes, lapiseira, etc.), e seu financiamento foi complementado por anúncios de, por exemplo, algumas representações de empresas alemãs no Rio de Janeiro. Na segunda edição, de setembro de 1933, encontramos o anúncio de meia página da "Escola de Arte Lasar Segall”, contendo uma foto da fachada do atelier da Rua Afonso Celso empresarial da Família Klabin. Não somente as associações cariocas PRÓ-ARTE e AAB-Associação dos Artistas Brasileiros - também os grupos paulistas SPAM - Sociedade Pró-Arte Moderna, à qual Segall e Warchavchik eram ligados - e seu rival CAM - Clube dos Artistas Modernos, liderado por Flávio de Carvalho e Carlos da Silva Prado dispõe-se à compra de exemplares que teoricamente garantiriam a continuidade da revista. Os pagamentos do SPAM e CAM não acontecem, e após novo esforço individual para publicar a terceira edição de base em outubro, que aparece como 'número especial' sobre propaganda e artes gráficas, Altberg é obrigado a declarar o fim da revista. ${ }^{37}$

No entanto, são as peças publicitárias de erico que irão melhor apresentar e representar ligações com as premissas bauhausianas, porém não sabemos ao certo se elas vinham prontas e/ou eram readaptadas no Brasil a partir de modelos internacionais, ou se realmente foram desenvolvidas e criadas no studio do artista. Mas, o fato é que elas circulavam em nosso país, mesmo que em revistas especializadas da área médica e farmacêutica, constituindo um repertório de imagens acessíveis. Vale relembrar que erico divulgou, em 1933, alguns de seus cartazes publicitários nas páginas da revista base, o que é indicativo que ele seguia a mesma linha editorial e que o meio artístico poderia conhecê-lo.

Afora o testemunho mesmo das imagens, a citação anterior de Pedro Moreira confere alicerce à presença de um modelo bauhausiano no material publicitário de erico.

\footnotetext{
${ }^{37}$ A citação foi extraída de Pedro Moreira, Alexandre Altberg e a Arquitetura Nova no Rio de Janeiro, in http://www.vitruvius.com.br/arquitextos/arq058/arq058_00.asp (10, 11, 12 of 17) 26/4/2007 17:11:31.
} 
Se em Quiniobis [FIG. 190, 1934] as formas geométricas surgem a partir de componentes figurativos humanos, em VACCINAS [FIG. 194, 1934] elas se acentuam numa quase abstração formal para tomarem formas definitivas de círculos, faixas retangulares e fios em ANTIPHYTOL [FIG. 191, 1934], conferindo ao espaço, com exceção daquele de que se ocupa o texto argumentativo, um campo perceptivo. Nestes três casos, as cores chapadas vermelho, preto e branco, que foram comumente utilizadas por artistas construtivistas [FIG. 192, 1936], ora distribuem-se nos nomes dos medicamentos, ora nas espessas tiras coloridas que se associam aos fios. ${ }^{38}$

As letras sem serifas também estão presentes nos tipos principais que nomeiam os produtos farmacêuticos. A parte textual é longa, informativa e explicativa, uma bula reduzida. Acreditamos que esse tipo de anúncio está muito próximo das funções de um folheto propagandístico. Tropicaluminio e VACCinAS também guardam entre si correspondências pela apresentação do texto em tópicos.

Apesar de não confirmada a autoria, acreditamos que SYNBRINA [FIG. 193, 1934] também seja uma peça publicitária de erico e a que melhor reúne os valores estéticos da Bauhaus. Nela a forma, com seus elementos e cores construtivas, é a própria comunicação visual, levando adiante as experiências de ANTIPHYTOL. De SYNBRINA consta somente a imagem reduzida às formas geométricas básicas e três únicas palavras (nome do produto e do laboratório e a função farmacêutica) que a ela se sobrepõem de modo a garantir tanto a informação necessária ao consumidor leigo, como a unidade da peça publicitária. Desse modo, SYNBRINA certamente reúne características que o colocariam na categoria do cartaz, mas desse anúncio ainda faz parte um texto argumentativo com linguagem médica. Este fato associado à sua divulgação em página inteira não paginada e em papel diferenciado, ${ }^{39}$ nos faz pressupor que seja um folheto farmacêutico, como sugerimos no parágrafo anterior, numa conclusão extensiva a ANTIPHYTOL, VACCINAS e QUINIOBIS.

\footnotetext{
${ }^{38}$ Os fios são peças de metal ou madeira utilizadas para produzir linhas horizontais e verticais de espessuras variadas. Eles foram amplamente utilizados a ponto de serem considerados um estereótipo do "estilo Bauhaus". Sobre o assunto consultar Richard Hollis, Design gráfico: uma história concisa, São Paulo: Martins Fontes, 2001, p. 63. Para uma confirmação das cores ver [FIG. 192, 1936], um cartaz de Hans Virtus Vierthaler.

${ }^{39}$ Geralmente, constam do verso das páginas dos anúncios farmacêuticos de erico outros nomes de medicamentos. Tudo indica que essas páginas poderiam ser destacadas da brochura.
} 
Se a fotomontagem do EliXIR DE InHAME Goulart [FIG. 1, 1922] ${ }^{40}$ que ao incorporar o produto farmacêutico ao cenário da Exposição Internacional do Rio de Janeiro (set. 1922), confirma a importância da publicidade, por outro lado dignifica o produto anunciado elevando-o a categoria do monumental, tal qual Mário de Andrade observou em seu artigo O culto das estátuas (1929). ${ }^{41}$ Mesmo que OdOL COMPLETA A HYGIENE DA BOCCA [FIG. 208, s.d.] não tenha se valido desse recurso fotográfico, encontramos analogias entre suas pesadas letras - tipos esculpidos ou objetos tridimensionais $-^{42}$ que funcionam como pedestais para os derivados do dentifrício em suas duas formas farmacêuticas: pasta e elixir. Este nosso último exemplo procura ressaltar os modelos publicitários que se utilizavam dos espaços em branco na constituição das palavras, bem como da associação entre tipos e imagens realistas dos produtos anunciados. Muito provavelmente este anúncio é uma readaptação de outros, pois em suas várias campanhas, tanto nacionais quanto internacionais, figuram as mesmas imagens dos frascos do Odol, a exemplo dos anúncios de Puttkamer e Kohout [FIGs. 178, 207] e até mesmo da peça publicitária de Di Cavalcanti, ODOL O MELHOR DETIFRÍCIO DO MUNDO [FIG. 41, 1928], que analisaremos em seguida no item CONTRIBUIÇÕES DOS ARTISTAS PLÁSTICOS NOS ANÚNCIOS COMERCIAIS.

\footnotetext{
40 Imagem reproduzida em Paulo Sutti, O reclame: a transição da reprodutibilidade persuasiva, São Paulo: Pontíficia Universidade Católica de São Paulo, 1996, p. 29. Dissertação de mestrado. Segundo o autor o anúncio do ELIXIR DE INHAME GOULART foi publicado na revista A Cigarra, (193), 1922.

${ }^{41}$ Este artigo já foi por nós examinado no capítulo anterior, p. 81.

${ }^{42}$ Nos anos iniciais do século XX, as campanhas internacionais de Odol exploravam o uso de suas letras de modo bastante criativo, a exemplo das LETRAS MONOLítICAS e ODOL NAS DIMENSÕES DE UM ANFITEATRO GREGO, anúncios publicados nos periódicos Jugend e Die Woche. Para uma consulta às imagens ver Milovan Stanic' , "Odol, l'art ambigu d'une publicité exemplaire”, in Centre Georges Pompidou, Art \& Pub: art et publicité 1890-1990, Paris: Éditions du Centre Georges Pompidou, 1990, pp. 156-159.
} 
Se as mais evidentes e reconhecidas ligações entre arte e publicidade européias ocorreram por meio do cartaz, em função deste ser reputado por muitos artistas como próximo da pintura de cavalete e, portanto, uma extensão das suas próprias produções

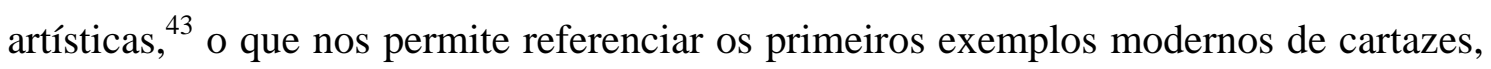
que se desprendem do formato anúncio, citando os de Jules Chéret e os de Henri Toulouse-Lautrec, e tantos outros artistas que desde a última década do século XIX aplicaram o cartaz à publicidade comercial, como Pierre Bonnard, Édouard Vuillard, Henri-Gabriel Ibels, Maurice Denis, Alphonse Mucha, Félix Vallotton, Aubrey Beardsley, Jan Toorop, Henry Van de Velde e Gustave Klimt, o mesmo não pode ser transposto para o caso brasileiro, visto que o enlace dos nossos artistas com a publicidade comercial deu-se antes pelas suas participações na produção de anúncios comerciais veiculados principalmente nas revistas do que propriamente nos seus envolvimentos com a cartazística.

Tal fato é fundamental, pois é a partir dele que nos arriscamos a afirmar que a verdadeira e significativa contribuição dos artistas plásticos na propaganda brasileira não foi dada pelos pintores, pela mancha e pela massa, como se poderia esperar e sim pelos profissionais do lápis, mais especificamente os envolvidos com a caricatura e a ilustração e que estavam engajados no trabalho da grande imprensa, a destacar os do Rio de Janeiro, cidade que mobilizava, como vimos, uma grande parcela desses profissionais.

Em se tratando da produção de anúncios comerciais dos ilustradores, herdeiros do desenho a traço, nosso parecer assinala que esses profissionais não renovaram a linguagem artística publicitária da época e tampouco apresentaram novas discussões a ela, porém, emprestaram-lhe uma técnica segura que pode muito bem ter sido adaptada aos modelos estrangeiros em circulação, como já vínhamos registrando. Este fato acrescido da falta de interesse dos nossos artistas plásticos pela cartazistica comercial basta verificar que essa modalidade de cartaz não foi vista por eles (pelo menos até a década de 30) como uma nova perspectiva profissional - talvez tenha imposto um

43 Não estamos desprezando a colaboração dos caricaturistas e ilustradores franceses e tampouco os vários posicionamentos dos discípulos de Leonetto Cappiello, como Cassandre, Paul Colin, Charles Loupot e Jean Carlu para os quais o cartaz, não necessariamente era tido como uma obra de arte, mas, fundamentalmente, como um meio de comunicação. 
grande intervalo entre a nossa produção publicitária de produtos e o seu específico cartaz, distância que só foi se atenuar com o ingresso e a participação no mercado de trabalho dos artistas gráficos estrangeiros, com a entrada no país das agências de propaganda americanas e com a circulação de revistas internacionais especializadas.

A partir de meados da década de 30, alguns nomes atuantes na publicidade, tais como erico, Mirga e Orthof, ${ }^{44}$ começam a emergir e aglutinar-se à produção de anúncios comerciais existente, bem como incrementar o interesse pelo cartaz, porém não mais por aquele acentuadamente artístico, pois esses profissionais carregam consigo preocupações com a legibilidade do cartaz e com mensagem publicitária. Se, a exemplo de erico, sua produção se mantém em proximidade com a cartazística européia, como veremos, já se notam acenos para uma outra produção que procura dialogar com os objetivos técnicos e científicos de uma nascente publicidade moderna que tem por base os modelos americanos.

Nesse âmbito, os exemplos de cartazes dos artistas plásticos que trazemos para os exames formais, são investidas individuais que na maioria das vezes permaneceram no projeto, a destacar os de Pennacchi. Porém, caso eles tivessem sido colocados em circulação, teriam não só se destacado da homogênea produção publicitária do período, mas também tidos como um alento renovador para o meio artístico.

Se não podemos claramente reconhecer artistas ou grupos de artistas plásticos engajados em determinadas modalidades de cartaz comercial (alimentos, bebidas, turístico, moda, espetáculo, teatro, cinema, saúde pública, etc.), por outro lado, reconhecemos a existência de uma produção cartazística, criada por esses artistas, promotora de seus próprios eventos culturais (bailes de carnaval, palestras, exposições, e outras atividades), que merece ser pesquisada, apesar de ser de alcance restrito.

Não podemos deixar de notar a lacuna historiográfica e crítica brasileira no que diz respeito a um estudo amplo e alentado da nossa cartazística. Infelizmente, não nos foi possível fazê-lo, não só pelo recorte proposto ao tema, mas, também porque os anúncios comerciais prevaleceram. Certo é que devemos considerar a produção de cartazes em seu todo, considerando os meios técnicos que lhe dão respaldo, bem como

\footnotetext{
${ }^{44}$ Deveria figurar entre esses nomes o do cartazista Ary Fagundes, porém, somente localizamos as várias capas criadas para a revista Light, uma para a revista Publicidade (1941) e uma para o disco MODINHAS FORA DE MODA de Lenita Bruno (1958). Encontramos duas imagens de cartazes comerciais (Philips e RÁdIO Mullard) em Publicidade: Revista Técnica de Propaganda e Vendas, Rio de Janeiro, (11): 24-25, 4 dez. 1931, porém devido à precariedade dessas referências visuais, optamos por não analisá-las.
} 
todos os agentes que dela participam, desde os desenhistas, impressores, artistas, tipógrafos, empresários, entre tantos outros profissionais. De imediato, reconhecemos a dificuldade que esta empreitada impõe ao pesquisador, devido principalmente à localização das peças, que pela sua transitoriedade são quase sempre descartadas, mas, certamente, só assim procedendo poderemos mapear e entender as características reais dessa obra. 


\subsubsection{CONTRIBUIÇÕES DOS ARTISTAS PLÁSTICOS NOS ANÚNCIOS COMERCIAIS}

Até meados da década de 1930, constatamos que são os artistas do lápis, formados na escola do desenho disciplinado da imprensa, os responsáveis pela produção efetiva e numerosa de anúncios comerciais, porém um menor número destes pôde dispor da criação diferenciada de alguns artistas plásticos e gráficos, até mesmo de arquitetos, independentes do circuito das revistas ilustradas, a exemplo dos que trataremos na seqüência.

Os anúncios comerciais do arquiteto M. Noziéres, LAUBisch-HiRTH [FIG. 54, s.d.] e a imagem publicada na revista Fon-Fon! [FIG. 55, 1932], são dois exemplos de móveis e ambientações considerados como modernos, pelos valores da época, pelas suas proposições de simplificação e geometrização das formas, o que igualmente se aplica às esculturas que decoram o ambiente. Infelizmente, as imagens não nos permitem averiguar se havia o emprego de outros materiais além da madeira, tais como o aço, pois a combinação de materiais distintos também é uma manifestação artística moderna que remete, num primeiro momento, aos princípios polimatéricos das vanguardas artísticas, a destacar o Futurismo.

Nozières se afastou da representação do mobiliário em forma de vitrine, com peças alinhadas de modo rígido e organizado. Ao contrário, obedecendo às novas visualidades dessa categoria de produtos que a publicidade veiculava na época, procurou dispor as peças uma ambientação realista em que se destacam as linhas dos objetos, porém, por não incluir a presença de seus moradores e o conforto por eles desfrutado, o efeito de sedução do anúncio se reduziu. Essa busca pelo conforto, pode ser levemente sentida na proximidade das poltronas do anúncio da revista Fon-Fon!, o que não ocorre em LAUBISCH-HIRTH pelo ângulo da cena que amplia o espaço.

Em contraposição a Nozières, o artista gráfico Correia Dias compõe uma peça publicitária para a casa CASTRO LEITE [FIG. 127, 1928], apoiando-se num grafismo linear pesado e de caráter decorativo. Uma imagem que dispõe rígida e ordenadamente “os objetos de arte” e os “artigos de gosto”, os quais concordam com a figura hierática no plano de fundo da imagem. Trata-se de uma ilustração publicitária que segue o bom desenho, mas não incorpora elementos plásticos e ícones modernos. 
Apesar de ser uma propaganda em rótulo, CANINHA-Cristal [FIG. 51, c. 1933], peça criada por Vicente do Rego Monteiro para um produto do seu engenho VárzeaGrande, merece ser examinada por depor a favor de uma estética moderna. Nela o que nos aprisiona não é o glamour feminino que a publicidade dos anos trinta explorava, entre outros, por meio das atrizes do cinema americano, e sim a imagem da mulher sedutora, a femme fatale que emerge do denso e negro plano de fundo, como um mundo subjetivo à parte. Desse recurso pictórico penumbrista, que nos anos 20 encontrou boa aceitação no meio artístico, também se valeu Di Cavalcanti em RETRATO, obra apresentada na Semana de Arte Moderna. ${ }^{45}$

Integram a composição de CANINHA-CRISTAL a figura feminina que vem das “profundezas”, a taça e a garrafa agigantada que divide com o cigarro aceso o primeiro plano da cena. As áreas brancas luminosas que perpassam pelo rosto da personagem, pelo cigarro e a sua fumaça e pelo rótulo da garrafa, criam um efeito inebriante, tal qual a fumaça e a bebida o fazem, funcionando como um elo para reforçar o convite desafiador que se encontra no modo de olhar da figura feminina colocada em posição frontal. A identificação do produto fica por conta das frases que circunscrevem a imagem num retângulo central.

Podemos dizer que CANINHA-CRISTAL ensaia uma tênue aproximação com a corrente modernista simbolista, seja pelo efeito penumbrista, pela representação das formas mundanas que procuram desvelar ligações inconscientes entre si, seja pelo encontro que a luminosidade propõe aos dois momentos cênicos: dois mundos contidos e separados, o subjetivo e o objetivo, o da figura feminina e o dos objetos.

Em SABOnete ARAXÁ [FIG. 58, 1936] do mineiro Del Pino ressalta-se a estilização formal do rosto e da mão da delgada figura feminina, sendo que o emprego de grossas linhas de contorno, pretas e cinzas, associadas às zonas mais densas e menos densas de cor, remete às técnicas utilizadas pelos cartazistas franceses dos anos 20. As letras também recebem um tratamento estilizado, o que garante a unidade da imagem, e vez por outra, as suas cores de preenchimentos se revezam, tal qual como ocorre nas faixas que contornam o rosto da mulher.

\footnotetext{
${ }^{45}$ Sobre essa obra de Di Cavalcanti e similares, consultar Aracy A. Amaral, Artes plásticas na semana de 22, 5ª ed., São Paulo: Ed. 34, 1998, pp. 175-177.
} 
A diagonal azul se harmoniza com o perfil sedutor feminino e com as outras faixas retangulares de uma possível manta que envolve o corpo da personagem criando um efeito em que afloram a fantasia e o desejo, mas a força sedutora fica mesmo por conta das linhas. Comumente, é indispensável a identificação visual ao produto, dada, através do desenho, pelo seu viés mais realista. Todos esses artifícios são freqüentemente encontrados nas imagens publicitárias dos anos 30.

Em Kelvinator [FIG. 134, 1937] de Nelson Boeira Faedrich, a opção pelo fundo negro, realça o produto de venda, uma geladeira, à qual o artista dedica uma concepção mais realista quando comparada ao restante dos elementos figurativos, que são figuras-bonecos construídas com poucas linhas brancas de diferentes espessuras. Apesar de esse anúncio ter sido realizado por um artista vinculado profissionalmente à Revista do Globo, julgamos interessante apresentá-lo pela técnica utilizada, a qual dificilmente encontramos. ${ }^{46}$

O único anúncio comercial localizado e produzido por Di Cavalcanti foi ODOL O MELHOR DETIFRÍCIO DO MUNDO [FIG. 41, 1928]. Comparando-se a peça deste artista com DeNTES COMO UM FIO DE PÉROLAS [FIG. 42, 1929], nota-se entre elas um grande distanciamento visual, seja pela escolha de seus modelos de representação, visto o segundo exemplo apostar no uso convencional e estereotipado da imagem da mulher, seja por serem duas concepções artísticas bastante distintas em seus vocabulários formais. Di Cavalcanti está muito mais próximo de uma linguagem artística. O segundo exemplo é um trabalho menos autoral, está excessivamente contaminado pelos valores técnicos da publicidade americana, que apostava na imagem mais realista e nos recursos do texto argumentativo, sobretudo no envolvimento do leitor com a repetição e associação de idéias, em particular, com a palavra Odol que se repete pelo menos quatro vezes e, com a brancura dos dentes tal qual a da pérola.

Identificamos no anúncio de Di algumas características da corrente Art Déco, entre elas um acentuado sentido de simplificação, que se verifica nos planos cromáticos sem sombreamentos, nas finas linhas que descrevem os rostos das figuras humanas, as quais se apresentam ora como linhas retas, ora como semi-círculos ou então como

\footnotetext{
${ }^{46}$ Não temos conhecimentos técnicos para confirmar a informação, mas levantamos a hipótese de que se trata do scratchboard, uma técnica bastante difícil, mas de domínio do artista e que consistia em passar nanquim sobre um cartão gessado americano e que depois seria raspado com um estilete, compondo o desenho. Sobre o assunto consultar Carla Fernanda Fontana, O ateliê de desenho da Livraria do Globo, São Paulo: Escola de Comunicações e Artes da Universidade de São Paulo, 2004, p. 183. TCC - Departamento de Jornalismo e Editoração.
} 
círculos completos. A redução do volume também é levada ao seu extremo pelo auxílio das linhas brancas que saltam da cor preta e do fundo azul. Os sutis elementos decorativos, a exemplo das linhas mais expressivas levemente onduladas do cabelo da figura feminina, não necessariamente correspondem a um mero acréscimo ornamental para obter efeitos de superfície, mas, integram a imagem principal, ao contrário das faixas horizontais coloridas, que mesmo sendo linhas retas não são formas puras, e não parecem ter outra função a não ser a de ornamentar. Sem apelos emocionais, Di criou uma peça publicitária que oscila entre uma linguagem construtiva, geométrica e com superposição de planos, e uma decorativa, de caráter expressivo e ornamental.

Se há depuração formal, por outro lado, para garantir a legibilidade do anúncio, há uma sua convivência com as legendas e os elementos realistas aplicados ao produto, como sugerem outros exemplos publicitários do período. Uma outra associação pode ser constatada, desta vez, mais no nível da sensibilidade visual do observador, no vazio aparente da boca que é preenchido pelo branco do papel e que se destaca do fundo preto: uma sugestão à brancura dos dentes proporcionada por Odol. A "forma branca que se destaca” pode ser verificada no cartaz CoL VAN HeUSEN de Charles Loupot (1928), mais especificamente no colarinho da figura personagem, porém se neste é a única referência à cor branca, em Di também a encontraremos na parte superior da camisa.

O espaço concebido pelo artista é notadamente interrompido, cortado por linhas verticais e horizontais que constroem uma moldura para a cena principal, como uma pintura fixa em um canto da parede. Desse modo, Di estabelece duas configurações formais dadas a partir da interioridade e da exterioridade das cenas, que respectivamente se ligam à simplificação das figuras humanas e à representação mais “fiel” do produto acompanhada da linguagem textual. Apesar de ODOL ser um anúncio, ele tem afinidades com o cartaz, pelo seu forte impacto visual e pela sua legibilidade, clara e concisa.

Não podemos afirmar se ODOL é a única peça publicitária comercial realizada por Di Cavalcanti, mas dela parte uma nossa inquietação: por que um artista que teve presença significativa e bom trânsito na imprensa teria realizado um único anúncio comercial e ainda datado de 1928, e não antes, quando muitos ilustradores o faziam e num momento de sua carreira em que estava mergulhado na caricatura? A única resposta que conseguimos formular, bastante óbvia por sinal, é que depois da década de 
20, prevaleceu seu interesse pela pintura e, como aponta Ana Paula C. Simioni, “o desenho passa a ocupar um lugar marginal em sua carreira”. ${ }^{4}$

${ }^{47}$ Ana Paula Cavalcanti Simioni, op. cit., p.66. 


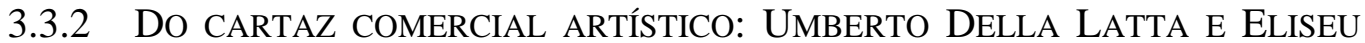

\section{VISCONTI}

Com o caricaturista e cartazista italiano Leonetto Cappiello nasce o cartaz moderno, por "romper definitivamente com o realismo a favor da expressão gráfica”, mas também por formular respostas às duas questões de fundo do cartaz: a legibilidade e a atribuição, como nos dá conta a citação de Alain Weill

Para ser legível, o cartaz deve ser despojado: um personagem claro sobre um fundo escuro, ou vice-versa - é o que ele chama de pesquisa da mancha. As cores utilizadas devem ser aquelas que melhor impressionam a retina. Mas, antes de qualquer coisa, o que faz um bom cartaz é a linha, o que ele chama de "arabesco", síntese da idéia: "É a linha que é preciso procurar e dar uma importância secundária à cor e aos detalhes que devem somente colocar em valor, o embelezar e o enriquecer”.

Para ser eficaz, o cartaz deve também ser imediatamente associado pelo transeunte a uma marca: é preciso, portanto, inventar um personagem animal, grotesco ou outro - que pela sua repetição, será indissociavelmente ligado ao produto. ${ }^{48}$

O cartaz bem humorado Loteria do Estado de S. PAulo [Fig. 165, 1928] de Umberto Della Latta faz evidentes referências visuais ao ChOCOLAT KLAUS [FIG. 166, 1903] de Cappiello.

Não podemos responder se o objetivo do nosso artista era somente fazer referência à iconografia do CHOCOLAT KLAUS ou se ele não percebeu ou recusou propositadamente as inovações formais que ele acenava. O cartaz de LOTERIA DO ESTADO DE S. PAULO pauta-se por um realismo formal e um tratamento minucioso das massas coloridas, propostas totalmente opostas às de Cappiello, que prefere as cores chapadas, a estilização que decorre da síntese formal e da linha de contorno - do efeito

\footnotetext{
${ }^{48}$ Alain Weill, L'affiche française, Paris: Presses Universitaires de France, 1982, p. 63. O autor identifica quatro cartazes de Cappiello que possibilitaram, em seu conjunto de contribuições (ruptura com o realismo pela busca da expressão gráfica, máxima legibilidade, eficácia, associação de um personagem a uma marca), a introdução da cartazística moderna. São eles: CHOCOLAT KlaUs (1903), ANIS INFERNAL (1905), THERMOGÈnE (1909) e CinZANO (1910). Por sua vez, os cartazes com derivações do cubismo: VOISIN (1923) de Loupot, LE BÛCHERON (1923) de Cassandre, LA RevuÊ NĖGRE (1925) de Colin e MonSAVON (1925) de Carlu, são considerados peças chaves na arte publicitária por romperem, nos anos 20, com os precedentes. Sobre o assunto consultar Henriette Touillier Feyrabend, “L'entre-deux-guerres ou le tournant d'un siecle”, V. A., Quand l'affiche faisait de la réclame! L'affiche française de 1920 à 1940, op.cit., p. 17.
} 
silhueta que define o assunto principal -, elementos que concorrem para uma simplificação, visando facilitar para o leitor a apreensão visual da imagem.

Tanto o cartaz de Umberto Della Latta quanto os dois estudos de Visconti, que trataremos a seguir, ligam-se ao cartaz artístico e não às proposições do cartaz publicitário moderno levantadas por Cappiello, proposições estas que se agregam, depois da Primeira Guerra Mundial, aos princípios científicos da publicidade americana em conjunção ao aparecimento de publicações da área que tratam, entre outras questões, dos estudos e regras de legibilidade, complementaridade das cores e planejamento de campanhas publicitárias. $^{49}$

Sempre se apoiando no estilo ornamental Art Nouveau, Eliseu Visconti concebe alguns estudos para anúncios e/ou cartazes, entre eles o projeto COMP ${ }^{\mathrm{IA}}$ ANTARCTICA [FIG. 29, c. 1920] pertencente à Coleção do Museu Nacional de Belas Artes, um trabalho concebido em técnica mista - aquarela e guache. Ainda para a mesma companhia, o artista realiza dois estudos para o pano de boca do Casino Antártica, sendo um deles COMP ${ }^{\mathrm{IA}}$ AnTARctica S. PAUlo - RiO DE JANEIRO [Fig. 211, s.d.]. Produz dois outros guaches para a CASA BEvILACQUA (s.d.) e, um nanquim com aquarela para a embalagem de charutos LOS CIGARRILHOS (s.d.). ${ }^{50}$

Dentre as características estilísticas constantes do estilo Art Nouveau, embora já menos vitais, e que se encontram tanto em COMP ${ }^{\mathrm{IA}}$ ANTARCTICA como também em COMP $^{\text {IA }}$ ANTARCTICA S. PAUlo - Rio DE JANEIRO, tem-se o uso de linhas onduladas, que no primeiro exemplo restringem-se as áreas dos cabelos femininos, na forma espiralada no canto esquerdo e no pano envolto no braço da figura feminina em primeiro plano, enquanto no segundo caso ela se espalha pela composição toda, seja no longo caminho branco na forma de S, nas curvas contínuas do corpo da mulher e nos seus cabelos esvoaçantes, nas demarcações geográficas do mapa-mundi, ou mesmo nos troncos e nos ramos das árvores que ocupam o plano de fundo. Se no projeto COMP ${ }^{\mathrm{IA}}$ ANTARCTICA S. PAULO - RIO DE JANEIRO, a devoção a natureza é uma prioridade do artista, basta ver a rica plantação de cevada desenhada, na FIG. 29 o clima de jovialidade, leveza e alegria dominam a cena. Por sua vez, a presença da arte japonesa pode ser observada, no

\footnotetext{
${ }^{49}$ Citamos os títulos La publicité lucrative et Sa Majesté la Publicité de J. Aren, Les affaires et l'affiche de Paul Dermer e Eugène Gourmont, e Traité pratique de publicité de Louis Auge. Alain Weill, op. cit, p. 76.

${ }^{50}$ Esses trabalhos são brevemente comentados no catálogo Eliseu Visconti e a arte decorativa. Rio de Janeiro: PUC/FUNARTE, 1983, pp. 12, 15, 36, 68, 70-73.
} 
primeiro exemplo, em elementos icônicos que se encontram nas três luminárias vermelhas, e na FIG. 211, na ilusão de espaço e profundidade sugerida pela visão do alto empregada pelo artista.

O uso que Visconti faz da grade em COMP ${ }^{\underline{I A}}$ ANTARCTICA não tem por objetivo separar o espaço interior do exterior, mas somente dividi-los; desse mesmo modo, o artista opta por apresentar o nome da empresa na parte superior da composição. E, se na FIG. 211, o símbolo da companhia Antarctica, uma estrela de seis pontas, encontra-se apenas esboçado, na FIG. 29, ele ocupa o lugar central do friso ao lado dos nomes Pilsener, Ypiranga, Teutonia e Bavária. Nos dois estudos de Visconti percebemos as diferentes e sutis experimentações tipográficas aplicadas à mensagem escrita.

Notamos alguns recursos interessantes e distintos que Visconti emprega nos dois anúncios comerciais. Na FIG. 29, escapa à regra a mão masculina que sai do espaço cênico ao ultrapassar a moldura do anúncio, tal qual em seu cartaz O BEIJO DA GLÓRIA A SANTOS-DUMONT (1901). Um segundo exemplo seria o braço em V da figura feminina do primeiro plano que conduz o observador para dentro da cena, criando ao mesmo tempo uma desproporcionalidade pelo efeito de monumentalidade, e como resultante desse jogo, o foco visual do quadro desloca-se para a esquerda. Na FIG. 211, o envolvimento ocorre por conta da linha em S, sinuoso e convidativa, numa composição de massas equilibradas pelo posicionamento do corpo feminino na faixa central do papel e pela ampla abertura de seus braços na horizontal, criando um efeito de cruz.

Não podemos deixar de mencionar que, enquanto nos anos 1920, o cartaz francês estava se impregnando dos valores formais de uma nova geração de cartazistas orientados para a síntese formal, no Brasil, Visconti ainda demonstra certo apreço pelas representações naturalistas e realistas, como denotam os detalhes e o modelado dos rostos das figuras femininas da FIG. 29; porém essas características se diluem na FIG. 211, devido o artista privilegiar o biótipo estilizado longilíneo, próximo das mulheres de Botticelli, o rosto ovalado, a inclinação do pescoço, cabelos compridos, ondulados e soltos ao vento lembrando a obra NASCIMENTO DE VÊNUS. Mas esses distanciamentos das regras acadêmicas não são suficientes para colocar seus exemplos de cartazes num patamar extra-artístico, mais próximo das exigências publicitárias que se delineavam, mesmo porque a legibilidade deles é comprometida pelo acentuado detalhe de suas composições.

Segundo Leonardo Visconti Cavalleiro,Visconti foi 
Precursor do Art Nouveau no Brasil, sua principal preocupação não era a de tornar-se um artista gráfico, nem tão pouco um desenhista industrial na época, e sim, com os infinitos recursos de estilização da arte decorativa, procurar uma nova forma de expressão, adquirida em seus estudos na Europa, visando o ensino da arte no Brasil. ${ }^{51}$

Acreditamos que devemos colocar um parêntese na observação de que Visconti foi o precursor do Art Nouveau no Brasil, pois nos parece que se este movimento não fôra acatado e divulgado, na época, no meio das belas artes, ele já poderia estar presente na imprensa no seio das ilustrações, das caricaturas e mesmo na publicidade das revistas ilustradas. Basta trazer à memória os anúncios de K.Lixto publicados no ano de 1902 [FIGS. 170, 171], ou mesmo considerar que:

No caso da publicidade, inicialmente, os clichês eram importados, observando-se muitas vezes na mesma edição, o mesmo clichê para vários anúncios diferentes. Geralmente, a importação destes clichês era proveniente da França (talvez esse fato tenha contribuído para a influência da "Art Nouveau” francesa), e muitas vezes usava-se o mesmo para anunciar a presença de um médico novo na cidade, como os últimos lançamentos de uma alfaiataria, sem nenhuma preocupação com a repetição do mesmo numa única edição. ${ }^{52}$

Caso nossa hipótese venha a se confirmar, novamente a imprensa escrita brasileira toma a dianteira do sistema oficial artístico, alinhando-se aos objetivos do estilo francês Art Nouveau, que desejava, numa primeira instância, entre outros, suprimir as barreiras entre as artes menores e maiores, sem contar que na prática as artes gráficas foram responsáveis pela sua divulgação mais ampla.

\footnotetext{
${ }^{51}$ Leonardo Visconti Cavalleiro, “Desenho Industrial”, in Idem, p. 13.

${ }^{52}$ Maria Sílvia Barros de Held, Considerações plásticas sobre “Art Nouveau” nos anúncios publicitários ilustrados do início do século XX em São Paulo, São Paulo: Escola de Comunicações e Artes da Universidade de São Paulo, 1981, p. 108. Dissertação de mestrado.
} 


\subsubsection{CARTAZETES PUBLICITÁRIOS PENNACCHIANOS (1929-1932)}

L'affiche exige du peintre un complet renoncement. Il ne peut s'exprimer en elle; le pourrait-il, il n'en aurait pas le droit. La peinture est un but en soi. L'affiche n'est qu'un moyen de communication entre les commerçants et le public, quelque chose comme le télégraphe. L'affichiste joue le rôle du télégraphiste: il n'émet pas de messages, il les transmet. On ne lui demande pas son avis, on lui demande d'établir une communication claire, puissante, précise.

Sans doute s'agit-il d'un message plastique. Mais si l'affichiste emploie les moyens du peintre, ils cessent d'être pour lui moyens d'expression individuelle, pour devenir langage anonyme, une sorte de code international, l'alphabet Morse du télégraphiste. ${ }^{53}$

Cassandre (1935)

Fulvio Pennacchi nos anos iniciais de sua transferência para o Brasil, entre 1929 e 1932, lançou-se na produção desenhos publicitários de cunho comercial. As assinaturas que constam nesses trabalhos, nomeados de cartazetes publicitários pelo próprio artista, vêm acompanhadas da designação Clamor ou Creação Clamor, ou tão somente Clamor. Possivelmente um ou outro seria o nome adotado pela sociedade entre Pennacchi e o escultor Antelo Del Debbio. ${ }^{54}$

Familiares do pintor confirmam que os artistas, nos anos iniciais da década de 30, manifestaram interesse em abrir uma empresa de prestação de serviços no ramo

\footnotetext{
${ }^{53}$ V. A., Quand l'affiche faisait de la réclame! L'affiche française de 1920 à 1940, op.cit., p. 109. A tradução das notas de Cassandre corresponde: "O cartaz exige do pintor uma completa renúncia. Ele não pode se expressar nele; mesmo se pudesse fazê-lo, não teria esse direito. A pintura é um objetivo em si. O cartaz não é mais que um meio de comunicação entre os comerciantes e o público, algo como o telégrafo. O cartazista desempenha o mesmo papel que o telegrafista: não emite mensagens, as transmite. Não pedimos sua opinião, pedimos-lhe que estabeleça uma comunicação clara, potente, precisa. Sem dúvida, trata-se de uma mensagem plástica. Mas se o cartazista emprega os meios do pintor, eles deixam de ser para ele meios de expressão individual, para se tornar uma linguagem anônima, um tipo de código internacional, o alfabeto Morse".

${ }^{54}$ Segundo Valério Pennacchi, "muito provavelmente Del Debbio seria o responsável pelo contato externo e a venda dos anúncios, visto que Pennacchi não tinha o menor pendor comercial”. Depoimento do Sr. Valério Pennacchi à autora, São Paulo, 2 jun. 2001.
} 
publicitário. Porém os trabalhos eram de autoria de Pennacchi, conforme consta no diário do artista, e que aqui novamente citamos:

\section{de 26 de dezembro a}

\section{6 de fevereiro de 1932}

[...] Em janeiro, pinto paredes para a patroa, e, em meados desse mês, com Del Debbio, monto um ateliê de reclames, e, na segunda quinzena, temos trabalho constante. Nesses dias realizei muitos projetos para cartazes publicitários [...]

\section{7 de março, terça-feira}

[...] O ateliê Clamor não rendeu mais nada. Realizei muitos projetos, nesses últimos dias, até dois desenhos para uma casa de moda, mas a dona, ao ouvir o preço de 120 mil réis só faltou bater na gente. Continuo desenhando, mas só para me exercitar. ${ }^{55}$

Na crise econômica de 30, Pennacchi além de tentar encontrar um meio de sobrevivência financeira e de colocação profissional por meio de trabalhos publicitários, também enveredou para a arte decorativa e para a arte funerária. ${ }^{56}$ Esta última era uma prática italiana, que aqui não foi adiante, pelo fato dos burgueses acharem muito chocantes os seus desenhos para túmulos, queriam algo mais acadêmico, o que lhe valeu o rótulo de futurista. ${ }^{57}$

Um número significativo dos cartazetes de Pennacchi, propriamente nove deles [FIGS. 64, 65, 66, 72, 75, 84, 87, 89, 91], indicam a concepção que o artista tinha da modernidade por meio da representação da cidade. Se a sua cidade, no geral, é prospectiva pelo número de altos edifícios que a ocupam, ela também é imaginária, pela sua organização, pelo seu silêncio, pelas ausências de conflitos e da agitação das multidões, correspondendo a uma visão idealizada, talvez de natureza crítica, coabitada por aqueles que nela caminham ou que freqüentam numa vida coletiva anônima seus cafés. Destarte, é ainda nesta mesma cidade quimérica que o artista deposita os seus sonhos pessoais e a sua verve poética.

\footnotetext{
${ }^{55}$ Cf. Mariarosaria Fabris (trad.), "Diário de Fulvio Pennacchi”, in Pennacchi 100 anos, São Paulo: Pinacoteca do Estado de São Paulo, maio - jun. 2006, pp. 114-115.

${ }^{56}$ Edição comemorativa dos quarenta anos de pintura de Fulvio Pennacchi, São Paulo: Museu de Arte de São Paulo Assis Chateaubriand, abr. 1973, p. 23.

${ }^{57}$ Ver "Pennacchi: 50 anos de criação na Oscar Seraphico", Correio Brasiliense, Brasília, 12 jun. 1979.
} 
Em CAfÉAbCDEfgh [Fig. 65], Pennacchi também concedeu lugar para a cidade nostálgica, aquela que deixou para trás ao se transferir para o Brasil. As reminiscências de sua cidade natal são confiadas aos tradicionais valores arquitetônicos italianos, sejam eles os sóbrios tons de terra dos telhados ou os edifícios toscanos. Só interfere nessa estranha quietude, próxima da poética metafísica de De Chirico, o vôo oblíquo da xícara-aeroplano.

Da sua construção do futuro não faz parte a "epopéia do trabalho", e sim a da publicidade de produtos, que se apóia no mito futurista da "cidade que sobe”, através do ângulo de tomada em contre-plongée que proporciona um engrandecimento dos prédios em vários trabalhos, a exemplo de Açougue Boi DE Ouro, O Chapeo Maravilhoso, CigARRos ABCDEFG, GRANDE FÁBriCA DE GUARDA CHUVAS E SOMBRINHAS, FÁBRICA DE GUARDA CHUVAS E SOMBRINHAS, IODOSAN A SAÚDE DA BOCCA E DA GARGANTA e IODOSAN, [FIGS. 64, 72, 75, 84, 87, 89, 91].

Se, na estética futurista, quando nos referimos ao dinamismo plástico, estabelecemos ligações visuais não só, mas também com a velocidade e com o movimento do objeto e do espaço que ele altera ao seu redor, em Pennacchi, as possíveis correspondências se encontram timidamente nas representações das sombrinhas voadoras que sobem às alturas [FIGS. 84, 87] e na xícara-aeroplano [FIG. 65], que, ao deixar seu sinuoso rastro de odor-fumaça na atmosfera, propaga o nome do produto. Elementos visuais que enredam a composição em uma ambientação surreal e que, de forma mais enfática, aparece em IodOSAN [FIG. 91].

No último exemplo citado, a racionalidade das linhas verticais dos prédios se contrapõe aos elementos subjetivos empregados que espetacularizam a cena. $\mathrm{O}$ frasco do medicamento, apoiado sobre uma larga faixa preta que informa o nome do produto, eleva-se à altura dos prédios, dentre os quais surge uma mão agigantada que segura um pequeno copo branco e que pelo seu gesto, oferece à amarela lua, personificada com sua boca aberta, o remédio para o alívio das dores de garganta. Essa situação inusitada criada para a peça publicitária do Iodosan, um medicamento do laboratório Zambeletti, constitui uma publicidade que dificilmente seria aceita pelo fabricante, pois as suas campanhas publicitárias do período como As GARGANTAS DE OURO DO BRASIL empregavam a fotografia de cantoras brasileiras em anúncios do gênero testemunhal, nos quais os seus depoimentos exaltavam as ações curativas do remédio que evitava as infecções da garganta. Num outro exemplo do mesmo produto, IODOSAN A SAÚDE DA BOCCA E DA GARGANTA [FIG. 89], as linhas ascensionais dos prédios e do frasco do 
medicamento dominam a cena e se valem da palavra Iodosan escrita verticalmente à esquerda do papel para um enquadramento do assunto principal. Mas, desta vez, o efeito surpresa fica por conta do casal, que, em sua altura, ultrapassa a dos prédios. Ao mesmo tempo em que os personagens gargarejam, envolvem com seus braços as estruturas de cimento armado, até que a mão feminina possa apanhar o frasco de medicamento que parece ter como tampa um chapéu.

Pennacchi, em diversos trabalhos, correlaciona o humano à solidez dos prédios, tal como ocorreu na FIG. 89, porém em A SAÚDE DA BOCA E DA GARGANTA IODOSAN [FIG. 90], parece ter petrificado a personagem e entalhado as mãos de sua única figura. Concorre para criar esse efeito o corte abrupto horizontal que elimina cerca de 2/3 do rosto, deixando à mostra somente a boca, que estabelece a ligação com o medicamento a ser ingerido. Um segundo exemplo é o busto masculino central de CHAPEO ARISTOCRÁTICO [FIG. 68], que impõe ao conjunto uma tridimensionalidade por meio das linhas do triângulo invertido. Por fim, a associação entre as massas robustas do boi e as geometrizações das pesadas formas arquitetônicas do volante AçOUGUE BOI DE OURO [FIG. 64, 1933].

Nestes dois últimos exemplos e também em muitos outros, o artista demonstra sua inquietação criativa, ao deixar em repouso os tradicionais modos de enquadramento das obras, as formas retangulares e quadradas. Ora servindo-se de triângulos, losango, círculos, arcos, ora combinando partes de formas geométricas distintas, Pennacchi demonstra o grau do seu envolvimento com estes cartazetes, uma pesquisa plástica e artística da melhor qualidade, que necessariamente inclui uma apurada disposição e escolha das letras.

É por meio da composição triangular e fechada de CigARROS CLAMOR [FIG. 77], ritmada pelo recurso da repetição ordenada e prolongada ao infinito, do homem como figura protótipo que ao repassar os mesmos gestos se dilui na massa, abdicando de suas linhas descritivas individuais que cada vez mais tendem à ser borrões de cor, que Pennacchi compreende a cidade moderna pelo viés da perda da identidade humana e a publicidade pela padronização de comportamentos e imposição de hábitos de consumo.

A série que Pennacchi concebeu para a divulgação de chapéus masculinos [FIGs. 68-74] é interessante pelo emprego do homem modelo, do homem manequim que posa simultaneamente em posição frontal e lateral os diversos modelos do produto, seja quando eles voam pelo ar, seja quando integram as cabeças de seus personagens. Com exceção de O CHAPEO UNIVERSAL [FIG. 69], no qual novamente a lua é personificada, 
os outros exemplos se orientam para uma geometrização das formas das roupas, dos corpos e dos rostos, porém não se trata de um procedimento construtivo radical, mas sim de uma busca pela simplificação, pois o artista ainda se vale do tratamento volumétrico de massas e dos detalhes realistas, apesar de suas figuras serem todas muito parecidas, quase réplicas.

Dentre essa produção destaca-se O CHAPEO ARISTOCRÁTICO [FIG. 68] que como mencionamos logo acima, impõe-se pela sua associação a um busto escultórico, solidamente construído a partir do volume de um triângulo que tem o seu vértice voltado para a parte inferior e mediana de um outro triângulo maior, contido por um verde espaço quadrado. Sem dúvida, trata-se de uma composição que emprega a construção geométrica, assentada em pontos medianos, determinando uma leitura verticalizada da imagem. A letra branca $O$, situada discretamente no vértice superior, cria com as duas outras letras $\mathrm{O}$, que ocupam o lado direito da imagem, uma imaginária linha oblíqua que revela um outro elemento da moda - o pince-nez, o qual se encontra representado em quase todos os outros exemplos desta série.

Pennacchi mostra-se atualizado ao não esquecer dos itens da moda. A moda não só se faz presente nos cartazetes dedicados aos chapéus masculinos, mas também nos comportamentos de suas personagens e nos seus acessórios, a exemplo dos trajes chiques do casal fumante da FIG. 75. Ainda, neste caso, sobressai-se do escuro tom do cenário, a ascendente fumaça branca do cigarro que serve de contraponto à descida da luz do letreiro luminoso localizado no alto do prédio e também à fumaça de um carro parado. Pennacchi explora o encantamento do anúncio luminoso por meio da mulher que se detém a olhá-lo, bem como insere pela primeira vez o carro em seus trabalhos. ${ }^{58}$

A lua, a xícara-aeroplano, os guarda-chuvas e as sombrinhas, elementos lúdicos e estranhos que ocupam o céu pennacchiano, podem ser mais bem compreendidos a partir do feixe de luz projetado do céu para a rua da FIG. 75. Parece-nos que os dispositivos visuais de que lança mão o artista funcionam como reclames luminosos que surpreendentemente roubam a cena e disputam no espaço aéreo a atenção do transeunte. Não é só a palavra projetada no espaço, mas, também o produto tomando a vez do luar e do céu escuro, como numa apresentação cinematográfica. Annateresa Fabris chama a atenção para a publicidade dos luminosos:

\footnotetext{
${ }^{58}$ Além desse cartazete, Pennacchi só usaria o automóvel em O PODEROSO CAMINHÃo A ÓLEO CRU [FIG. 103], porém como enunciação visual de um modelo de caminhão da marca Fiat e, não como um fascínio por sua modernidade.
} 
A celebração do artifício luminoso, que derrota a escuridão e estabelece uma claridade permanente, faz parte da exaltação geral do dinamismo, que não se limita ao paradigma central da velocidade, mas abarca também a animação do espaço urbano pelas multidões e pelo reclame, criando imagens fragmentárias, fugidias, que se interpenetram e intensificam a percepção com suas mudanças repentinas de ângulo de visão, com seus choques sucessivos a requererem constantes adaptações óticas e psicológicas. É por isso que os pintores futuristas desejam colocar o espectador no centro do quadro para que ele possa participar desse modo de captação da realidade, no qual o presente e o passado - o visto e o lembrado - se fundem e se confundem. ${ }^{59}$

Essa aproximação aos luminosos se torna evidente em O MAIS SABOROSO CAFÉ [FIG. 66], quando a seta oblíqua ascensional conduz o olhar aos letreiros no topo do prédio, talvez por meio do reflexo no espelho, porém essa forma de publicidade da cidade moderna convive com a crítica que o artista promove à solidão das pessoas que a habitam - indiferentes e como autômatas levam suas xícaras de café à boca, cada qual em seu nicho impenetrável.

O conjunto de trabalhos dedicados aos pneus Pirelli [FIGs. 104, 105, 106, 107, 214, 215, 216] não evoca as imagens do carro ou do avião como se poderia esperar, mas sim as do automobilista e/ou do aviador, estes em substituição ao mito de Ícaro. Talvez, porque Pennacchi tivesse por objetivo exaltar a presença da fábrica italiana em solo brasileiro, visível não só nas cenas em que sugere a extração da borracha, mas, também naquelas nas quais explicita a relação ítalo-brasileira por meio das bandeiras desses países. Nas FIGs. 107 e 215, o pneu é o portador da marca anunciada ou seja, é o próprio produto que se anuncia, mesmo que ainda seja por meio do desenho e não de uma fotografia. Pode-se entender que a FIG. 104 propõe um dinamismo pelas suas diversas diagonais conjuntamente com o efeito elíptico ascendente da figura masculina que sai de dentro dos pneus, sendo que seu cabelo esvoaçante confirma o movimento. Às vezes, esse pneu se torna monumental, sendo alçado a símbolo da mecanização [FIGS. 105, 216], em outras ocasiões, é a sua qualidade que está em jogo, seja pela alta extração em série da borracha que garante a sua fabricação [FIG. 107], seja pela robustez do aviador/automobilista que o empurra [FIG. 106], ou, finalmente, pela simbiose entre o pneu que tem mãos de borracha e os homens que o utilizam ou o

59 Annateresa Fabris, Fragmentos urbanos: representações culturais, São Paulo: Studio Nobel, 2000, p. 120. 
fabricam [FIG. 215]. Nestes trabalhos, Pennacchi valoriza a relação do homem com os aparatos industrializados e com os ícones modernos, colocando-o no centro do assunto como peça participante dessa engrenagem contemporânea.

Pennacchi em As MAIS MODERNAS CREAÇÕES [FIG. 63] contribui de maneira ousada para os reclames da época, diferenciando-se dos anúncios das meias Visetti, no qual a figura feminina está sentada no topo do prédio, uma evidente associação ao edifício Martinelli - “as duas alturas máximas da América do Sul” -, ou ainda, das meias Holeproof, em que as pernas femininas são desenhadas a partir de linhas sóbrias e elegantes sem criar algum fetichismo.

Comparando seu cartazete com a peça publicitária de Nino, EDIÇÕES “SIP” COLEÇÃo ECONOMICA [FIG. 115, 1933], notamos que a sua proposta de exposição fragmentária das pernas femininas não é uma inovação, mesmo porque a fragmentação do corpo foi bastante empregada a partir dos anos 30 pelos surrealistas ${ }^{60}$ e pelos publicitários, estes visando seduzir o público consumidor. ${ }^{61}$ Porém, se na FIG. 115 elas são expostas para enfatizar o conforto que decorre de uma leitura agradável, sendo perceptível as suas continuidades físicas, na publicidade pennacchiana ficam claras as suas interrupções com o restante do corpo, mesmo porque as sensuais pernas ali presentes estão desprendidas como linhas, formas e volumes soltos ao ar; são, antes de mais nada, funções plásticas distanciadas de uma narrativa temporal.

Pennacchi, ao se utilizar da sinédoque, do fragmento multidirecionado e superposto, focaliza a atenção do observador no produto, que, no caso, bem poderia ser o conjunto de sapatos, pois as meias quase não aparecem. Talvez seja essa a intenção do artista: revelar a transparência das meias, ou ainda, como elas tornam as pernas mais belas.

Na publicidade de medicamentos temos OpOGASTRINA [FIG. 88], um cartazete elaborado com os quadros do antes, durante e o depois, TOSSE ForCREAl [FIG. 93] e Forcreal CURA QUALQUer tosse [Fig. 92]. Em todos eles, Pennacchi compõe sua

\footnotetext{
${ }^{60}$ A agência New York Agency Cecil \& Presbey, Inc., publicou uma série de anúncios para revistas, em 1946, para o cliente Brian Hosery Mills, do artista surrealista Salvador Dali, nos quais se encontram fragmentos de pernas para divulgar marcas de meias femininas. Algumas dessas imagens figuram em http://katia.cabaretvoltaire.com/blog/archives/2002_02.html, pp. $3-4,22$.

${ }^{61}$ A fragmentação foi utilizada na publicidade para criar tensão e ambigüidade, mas também pela sua sedução, sobretudo a partir da década de 40. Para um estudo do assunto remetemos o leitor ao livro de Juan Carlos Pérez Gauli, op. cit., pp. 122-140.
} 
narrativa com cenas estilisticamente realistas que conduzem o doente atormentado ao alívio do medicamento, enveredando para o humor leve, propriamente popular, de fácil compreensão. É possível que este recurso tenha sido utilizado para manter proximidade com os anúncios do gênero do período, como LUGOLINA, EU ERA ASSIM E FIQUEI ASSIM, CÊRA DR. LUSTOSA, ELIXIR DE INHAME, etc.

Os diversos cartazetes de Pennacchi que anunciam perfumes, produtos de decoração, medicamentos específicos para mulheres [FIGS. 80, 81, 82, 83, 94, 95, 97102], nos quais a figura feminina se destaca ou é o assunto principal, necessariamente nos fazem indagar sobre as possíveis ligações desta produção com a pictórica. As representações artísticas e publicitárias desses trabalhos já se encontram mais “comportadas” e afinadas aos seus objetivos publicitários. De modo geral, Pennacchi desnuda as suas referências socioculturais ao construir e “conter” a figura feminina em arcos ou em molduras, isolando-a de modo a protegê-la, o que se coaduna com a fragilidade e a delicadeza que o artista atribui a essas imagens; assim, quase todas elas se encontram carregadas de estereótipos femininos que envolvem a beleza, a saúde, a sua relação com a natureza e a família. Em CigarRos SusANNA e CigARROS DAS SENHORAS [FIGS. 76, 78] a representação da mulher se envolve com outros parâmetros originários de uma suposta solidão cosmopolita ou de uma emancipação feminina.

E, em termos estilísticos, nessa produção publicitária, em particular, nas imagens femininas, nota-se com mais clareza a presença de uma estilização e sintetismo formal, que se acentuarão em suas futuras pinturas. Porém, acreditamos ser de pouca relevância encontrar ressonâncias entre os cartazetes e os trabalhos em arte pura de Pennacchi, pois, certo é que eles não são subprodutos, são trabalhos bem cuidados, planejados artisticamente e realizados com primor. Arriscamos a dizer que, no momento em que o artista realizou essa produção publicitária, ele também nutria e engendrava seus futuros tipos humanos pictóricos.

Aventando os motivos que levaram à não efetivação de Clamor e conseqüentemente à não execução dos projetos publicitários pennacchianos, elencamos algumas hipóteses, como

- semelhantemente aos desenhos para túmulos, os cartazetes publicitários também poderiam ter sido recusados por serem classificados como "futuristas", assim como seria muito difícil para Pennacchi fazer concessões de sua arte a fim de adaptá-la ao gosto corrente; 
- os artistas não teriam conseguido os clientes que almejavam’ a exemplo do café Paraventi, da Fiat, da Pirelli e do laboratório farmacêutico Zambeletti;

- o preço cobrado, considerado alto.

Um outro ponto que defendemos, apesar de todo o esforço do artista, é que nos cartazetes pennacchianos predominou a linguagem artística sobre a publicitária. Fato este que não diminui o valor do artista e da sua obra, somente o coloca ao lado daqueles, como o cartazista Jean Carlu, para quem

o cartaz deve ser uma obra de arte. O cartaz, obra de arte, expressão do espírito humano, tem por objetivo essencial provocar uma emoção ou de elevar uma idéia na alma do espectador... Seu papel é o de associar um nome a uma imagem com objetivo de propaganda. ${ }^{62}$

Ou, como colocaria, em anos bem mais adiantados, Guilherme de Almeida, num exercício estético sobre o cartaz publicitário que o distancia de sua inovadora criação COMA LACTA, pois na visão do poeta a cartazística está associada à pintura, como obra de arte ancorada em valores miméticos. Nesse sentido retomamos a sua crônica, já citada no capítulo 2, pois ela talvez traduza as impressões acerca do que se esperava de uma propaganda externa, como o cartaz de rua:

\section{Um cartaz}

Pára-se na rua para ver uma vitrina, um incêndio, uma prisão, um desastre, ou então uma linda mulher (que é tudo isso ao desastre) ... Pela primeira, vez na minha vida, eu parei e vi gente parar na rua, anteontem, para ver ... o que? -- A coisa feita expressamente para ser vista e que, de tão feia e inexpressiva sempre, jamais consegue o que pretende: um cartaz.

Como o táxi, que me levava, corresse ao longo de um tapume para tomar, à direita um viaduto, vi, sobre o pinho pintado de alcatrão, uma pequena, deliciosa, raríssima obra de arte. Um quadro - um pastel - de linhas seguras e novas, tons de doce harmonia, composição sugestiva. Dei ordem ao "chauffeur" que parasse: e fiquei uns instantes (aqueles poucos que me permitiu o "grilo") olhando a adorável coisa, como se olha, numa galeria de arte a tela que seduz. E vi, adiante, à frente de outros tapumes, grupos parados, olhando o mesmo cartaz, o cartaz "certo": isto é, fascinante e, pois, eficiente. Não sei o nome do

\footnotetext{
${ }^{62}$ Réjane Bargiel, op. cit., p. 23. O cartazista francês manifestou esse seu parecer em setembro de 1928.
} 
desenhista; ignoro se foi, ou não, o resultado de um concurso entre artistas especializados. Tudo o que sei, tudo o que não ignoro é que esse é o primeiro cartaz nacional, que conheço, digno de ser visto; o primeiro que, em vez de emporcalhar, enfeita a cidade; o primeiro que dá a essa feição da publicidade fôros de Arte; o primeiro que a gente até gostaria de levar para casa e ter enquadrado no canto predileto do seu "studio", numa lógica convivência com o óleo a aquarela (sic.); a gravura que põem um sonho nos olhos abertos... É o prestigioso convite para o Grande Prêmio "São Paulo", a ser corrido depois de amanhã no Hipódromo de Pinheiros;- um rosto de mulher moderna, esmaecido num mistério calmo, traçado por quem entende, mesmo de mulher, de beleza, de moda, de elegância e de "arte do cartaz", formando o primeiro plano, sobre um fundo vago de "landscape" turfista com vivo e feliz movimento e jogo sábio de tons.

Isso é um Cartaz (a maíuscula impõe-se). Ao lado dele, por aí, esses horrores degradantes que ... Mas nem é bom falar.

Temos uma Prefeitura, temos uma Associação Paulista de Propaganda. Esta ou aquela, ou aquela e esta, entrosadas, bem poderiam estabelecer um prêmio anual ao melhor cartaz que dignificasse o nosso renome de cidade civilizada. Seria, pelo menos, uma oportunidade para ... "fazermos o nosso cartaz"...

Talvez Guilherme de Almeida e Pennacchi acreditassem, como Cassandre, que o cartaz pudesse oferecer ao pintor o meio de "reencontrar o contato perdido com um largo publico", 64

${ }^{63}$ Guilherme de Almeida, “Um cartaz”, Rio de Janeiro, 30 abr. 1948, p. 3. Recorte de jornal localizado na Divisão de Pesquisa do Arquivo Multimeios da SMC-PMSP do Centro Cultural São Paulo. Trata-se de um copyright do Diário de S. Paulo. O cartaz referido pelo poeta é do artista Danilo Di Prete e foi publicado em A Gazeta Esportiva, São Paulo, 1 de maio de 1948.

${ }^{64} 150$ ans de publicité: collections du Musée de la Publicité, Paris: Union Centrale des Arts Décoratifs, 2004, p. 62. 


\subsubsection{O MODERNO NOS ANÚNCIOS E CARTAZES COMERCIAIS PUBLICITÁRIOS: BARÃO PUTTKAMER, ERICO E ORTHOF}

TODA HORA DE DOENÇA É UM TEMPO PERDIDO PARA O PRAZER DA VIDA [FIG. 179, 1929] do BARÃo PUTTKAMER confirma a presença no meio publicitário artístico brasileiro de uma tendência internacional que fazia uso simultaneamente de elementos geométricos e de diagramas. Essas características verificam-se neste anúncio comercial, do medicamento A Saúde da Mulher, porém um tanto adaptadas. O artista planejou seu trabalho a partir do círculo, o de maior diâmetro remete aos dias do ciclo menstrual da mulher, enquanto os pequenos círculos se encarregam, por meio de suas imagens, do relato dos “prazeres da vida que estão sendo perdidos”. Particularmente, este caso nos interessa, pois as concepções que nele transitam, tais como conteúdos dentro de conteúdos, círculos que se sobrepõem ao assunto central e as imagens auto-explicativas, que também estabelecem um diálogo orgânico com o longo texto situado na metade inferior do anúncio, relacionam-se, como estratégias visuais, ainda que superficiais, aos trabalhos de artistas que empregavam a fotografia, mais especificamente a fotomontagem e os diagramas, a exemplo da brochura BALANÇAS BERKEL (1930) de Paul Schuitema e o livrete de instrução de telefone PTT (1932) de Gerard Kiljan. ${ }^{65}$ No mais, esse anúncio recorre ao estereótipo da mulher frágil e incapaz.

Dentre outros anúncios comerciais que aqui merecem ser considerados também devido aos diálogos empreendidos com imagens e estilos internacionais sejam eles artísticos e/ou publicitários, citamos novamente alguns exemplos de erico de meados dos anos 30 tomados da revista Medicina, Cirurgia, Pharmacia.

Se em INCURSõES PELAS LETRAS E IMAgENS, erico revelou-se conhecedor dos modelos bauhausianos, nos anúncios: Digestão Perfeita [Fig. 195, 1935], STHENoSEdans [Fig. 200, 1934], CALfix [Fig. 197, 1935] e GotTas Physiologicas [Fig. 199, 1934] e no cartaz Restaurant AtAlaia Hotel [Fig. 183, 1933], encontramos o artista próximo da produção, do final dos anos 20 à década seguinte, dos principais cartazistas franceses como Jean Carlu, Charles Loupot, León Dupin e Francis Bernard.

Como mencionamos diversas vezes não sabemos ao certo se essas peças publicitárias foram criadas no Brasil, ou se vinham prontas das matrizes dos

\footnotetext{
${ }^{65}$ As imagens podem ser consultadas em Richard Hollis, op. cit., pp. 72-73.
} 
laboratórios farmacêuticos, ou ainda se eram originárias de agências de propaganda, mas é inegável a presença de imagens de intermediação, o que se nota em KAOLINASE BELladONADA [FIG. 188, 1938] ${ }^{66}$ que indiscutivelmente é uma apropriação das formas femininas dos sintéticos e diversos cartazes de divulgação do Salon des Arts Ménagers, que desde 1923 eram organizados na França. Como exemplo, citamos os trabalhos de Francis Bernard [FIG. 212, 1931] e de Roger Perot [FIG. 213, 1935].

Se ainda é possível encontrar correspondências entre VACCiNAS [FIG. 194, 1934], STHENO-SEDANS [FIG. 200] e CALFIX [FIG. 197], pelo máximo de simplificação e geometrização das figuras humanas, o tratamento das cores converge para outras propostas.

CALFIX, com suas sobreposições de silhuetas e de cores, não deixa de dialogar com Carlu pela proposta construtiva de geometrização das formas, e com Loupot pelo tratamento esfumaçado e pelas nuanças das cores. Se a superposição de silhuetas geralmente visa reproduzir um gesto, multiplicar significados e intenções, e também dinamizar a composição, neste caso ela está antes associada a dois estados de saúde, um deprimido e comprometido que se localiza no plano posterior e, outro representado pela figura masculina saudável do primeiro plano, que se liga à cor vermelha (tal qual em Tosse? BROMIL, FIG. 121) diretamente ou por meio do preenchimento do nome do medicamento. As várias diagonais que revezam as cores vermelhas e pretas, da barra de peso, do braço da figura principal, dos nomes do laboratório e do medicamento impressionam fortemente a leitura da imagem.

Por sua vez STHENO-SEDANS também faz uma combinação de características estilísticas dos mesmos cartazistas franceses. Nota-se nesta peça publicitária uma aproximação com Carlu no emprego das linhas quase que construídas com a régua e o compasso. Todavia é a linha contida num plano chapado de cor do cartaz MonsAvON [FIG. 189, 1925] que mais aproxima os dois artistas. E em erico, a cor porém, não é distribuída uniformemente, mas sim à maneira de Loupot, como uma cor que se constitui com passagens suaves, como se fossem massas areadas que ocupam e ultrapassam o interior da cabeça, remetendo a um "halo", que suaviza as linhas acentuadamente geométricas da figura. E, novamente, as cores, vermelha e preta, predominam no anúncio de erico.

\footnotetext{
${ }^{66}$ Kaolinase Belladonada foi publicada na revista Medicina, Cirurgia, Phamarcia, Rio de Janeiro, (24): s.p., mar. 1938.
} 
Esse efeito do "halo" melhor está representado em GoTTAS PHYSIOLOGICAS [FIG. 199], porém neste caso a representação da figura humana não segue o princípio de geometrização das linhas, mas permanece o de redução formal. Em DIGESTÃo PERFEITA [FIG. 195], o artista, ao combinar o desenho geométrico com a fotografia de uma ave, não perde de vista a depuração das formas. erico faz da fotografia um elemento da composição gráfica por estabelecer uma continuidade visual entre as duas linguagens; as linhas da ave adentram o campo desenhado, não só reverberando-o, mas também criando uma imagem em raio-x da parte interna do corpo. Esse anúncio comporta um diferencial pelo uso da fotomontagem. Se o desenho ensaia uma aproximação com a realidade, se deseja sugerir algo, a associação à fotografia é positiva no que esta comprova, complementa e enfatiza essa mesma realidade. Neste último exemplo o “halo” não está somente na parte interna da figura, mas também ao seu redor.

Não são somente os exemplos publicitários de erico que, na década de 30, se apropriaram do efeito "halo" de Loupot. É o que podemos deduzir a partir da capa da Revista do Globo [FIG. 198, 1939]. Este fato bem pode ser indicativo do quanto este recurso fôra disseminado, afora que Ernest Zeuner em seu anúncio comercial ELIXIR BIIODADO SANTO EXPEDITO [FIG. 129, 1931] de certo modo já o empregava. ${ }^{67}$

Se, antes, as contaminações estilísticas de erico estavam associadas à revista farmacêutica, que bem poderia ser representante no Brasil de medicamentos importados da França, o artista no cartaz Restaurant Atalaia Hotel [Fig. 183, c. 1933], divulgado na revista base, explicita as suas preferências por Cassandre e Loupot, respectivamente, por meio dos cartazes PARTOUT ... A VOTRE SERVICE. WAGONS-LiTS COOK (1933) e $S^{T}$ RAPHAËL QUINQUINA [FIG. 184, 1937], ao se apropriar da imagemsilhueta das formas geometrizadas que flutuam no espaço. Na FIG. 183 um garçom que salta pelos ares tem as cores de seu corpo invertidas em combinação com os produtos das duas bandejas que segura nas mãos. Embaixo, o reconhecimento da cidade, como o cartazista francês fez ao incorporar à imagem a torre Eiffel, por meio da estilização dos morros, da praia e do mapa que indica a localização do hotel em Copacabana.

\footnotetext{
${ }^{67}$ Se a modernidade das capas da Revista do Globo também é atribuída às revistas estrangeiras que por lá circulavam, nós acreditamos que o mesmo possa ter ocorrido com o seu material publicitário. Sobre o assunto consultar Paula Viviane Ramos, A experiência da modernidade na Seç̧ão de Desenho da Editora Globo. Revista do Globo (1929-1939), Porto Alegre: Instituto de Artes da Universidade Federal do Rio Grande do Sul, 2002, pp. 248-249.
} 
Em Psiu! Um CinZANo [Fig. 186, c. 1933], erico brinca com o efeito sombra e o plongée, numa representação dinâmica da figura humana construída com poucos traços, marcadamente geométricos, enquanto os elementos da bandeja recebem um tratamento mais detalhado. A cena é enquadrada pela distribuição das palavras.

ODOL [FIG. 185, c. 1933], talvez seja o melhor exemplo de cartaz de erico, pela economia de elementos formais, que se resumem à representação de uma boca excessivamente sorridente, e pelos elementos tipográficos que compõem o nome do dentifrício e que estão encarregados de ao mesmo tempo representarem os olhos e o nariz, bem como a marca do produto. Trata-se de uma composição ancorada pela letra, em que cada uma delas se comporta como matéria viva. Em verdade, erico soube criar um cartaz breve e conciso em suas formas, dispensando detalhes supérfluos e textos.

Este exemplo pode ser colocado ao lado das notas de Carlu e das observações de Alain Weill:

"O cartaz é um meio de propaganda destinado a associar um nome a uma imagem, é portanto necessário reduzir seu papel a só essa ambição”. Mas para atingir essa meta há um certo número de regras que devem ser respeitadas: "Para ficar gravado no espírito do transeunte, o cartaz deve ser uma composição fechada, ritmada por um sistema geométrico simples, que suspende o olho mais facilmente que uma composição limitada e amorfa”. Chegamos assim àquilo que Carlu chama "expressão gráfica da idéia”, que é a regra de base do cartaz. ${ }^{68}$

Os cartazes de Orthof, apesar de guardarem uma significativa distância formal dos de erico, podem ser a ele filiados pela mesma preocupação de legibilidade dada a partir de um geometrismo gráfico e apuro das formas. Assim é em A ESQUINA DA SORTE [FIG. 180, c. 1933], um entrecruzamentos de linhas diagonais que têm como ponto de fuga um círculo preto central que determina a localização da loja e que conduz a figura desenhada ao local. Na realidade, se as linhas parecem sugerir um convite, são as duas áreas pretas que enfaticamente o fazem. Em PAPÉIS PINTADOS CASA DAVID [FIG. 182, c. 1933], o artista aproveita-se das linhas verticais e horizontais geradas pelo desenrolar dos papéis para criar um efeito de sobreposição, bem como alinhar e incorporar à imagem as quatro palavras dispostas nestas duas direções. Essa peça publicitária, muito

\footnotetext{
${ }^{68}$ Apud Alain Weill, op. cit., pp. 85-86.
} 
se aproxima de BAUHAUS TAPETEN de Herbert Bayer (1926-1927), pelo movimento estático e descritivo dos rolos de papéis. ${ }^{69}$

A peça publicitária de Mirga, PARAVEnTi [FIG. 205, s.d.], pelo seu conteúdo visual, nos induz a classificá-la como um cartaz. O braço levantado na diagonal que surge do escuro plano de fundo conduz a atenção para a mão agigantada do primeiro plano que, ao esboçar um gesto de parada do guarda, nos faz necessariamente ler o nome da marca de café anunciada. As distribuições seqüenciais das massas brancas auxiliam a leitura continua na diagonal. Esse artifício de agigantar a imagem do plano da frente foi também explorado por Nelson C. Boeira Faedrich em um dos seus anúncios da Cervejaria Continental, [FIGs. 132, 133, c. 1935], naquele em que o copo de cerveja se contrapõe em tamanho e em importância visual ao elefante da cena. Esses últimos exemplos muito se distanciam das propostas mais inovadores de erico e de Orthof de um desenho essencial e imediato, por deixarem prevalecer a mensagem publicitária assentada na norma realista de representação e no jogo associativo entre imagem e palavra que os colocam filiados à ilustração comercial.

\footnotetext{
${ }^{69}$ A imagem de Herbert Bayer pode ser encontrada em Eckhard Neumann, op. cit., p. 399.
} 
CONCLUSÃo 
Décio Pignatari - [..] A agência de propaganda, com tudo que ela tem de horroroso, de péssimo e de pressão, tem muito de criativo e muito de responsável pelo avanço da visualidade, não só no Brasil, como em muitos outros lugares.

Humberto Franceschi - Dificilmente, você pegará um anúncio na rua, seja ele qual for, que você não encontre o original. $[\ldots]$

Décio Pignatari - Criação brasileira quer dizer capacidade de deglutir o estrangeiro e dar uma resposta nova. Isso é que significa criação brasileira.

Capacidade de criação brasileira é a capacidade de deglutir o que há de melhor no estrangeiro e dar uma resposta a isso.

Moderador - E por que não criar também, independente de deglutir?

Décio Pignatari - Porque, de algum modo, você tem que captar dados. Não é o caso de saber quais são os dados originais brasileiros, eles existem. Mas, de qualquer maneira, em matéria de tecnologia, é necessário atuar criticamente sobre a tecnologia para que não nos detenhamos inutilmente sobre tecnologia superada.

$[\ldots]$

Décio Pignatari - [...] O que se vê é que há determinadas propostas que se revelaram muito ricas como projeto. Não se fez e seria uma coisa muito importante de fazer, como foi e que importância teve - e acho que era de uma grande importância - a revolução na visualidade a partir da Semana de Arte Moderna de 1922. Os livros que se publicaram naquele período (de 1922-1930), com recursos mínimos, tinham uma enorme capacidade inventiva. $\mathrm{O}$ artista daquele tempo, que aparentemente, podia ser até o artista mais tradicional como Tarsila, o próprio Di Cavalcanti e outros, se dedicaram aos trabalhos - os mais das vezes humildes - de ilustração. Quando Tarsila desenha, em 1925, uma capa com o paubrasil, em que tinha a bandeira brasileira, isto era uma inovação em toda a visualidade do mundo naquele tempo. Passaram-se 35 anos e o Jasper Jones ganhou o prêmio (seis mil dólares) aqui, porque pintou a bandeira americana. Quer dizer, são essas proposições que são apresentadas e afogadas, porque o sistema se sente ameaçado por elas, mas eram proposições riquíssimas no sentido cultural. A proposição do pau-Brasil e do manifesto antropofágico eram proposições culturais gerais que tiveram conseqüências no mundo visual e em vários outros mundos da cultura brasileira. Essa tradição da revolução visual que se fez em 1922 se perdeu logo depois de $1930 .^{1}$

\footnotetext{
${ }^{1}$ V. A., "Mesa redonda", in $\mathbf{O}$ desenho industrial no Brasil: ensino e mercado de trabalho, Rio de Janeiro: Mudes-Ilari, 1970, pp. 72-73, 78-79.
} 
Em um período de significativas mudanças, quando da passagem do reclame à implantação de uma publicidade técnica americana e de uma solicitação artística moderna, Diálogo entre as Artes Plásticas e a Publicidade no Brasil propôs examinar a participação das diversas categorias de artistas plásticos na propaganda comercial brasileira.

De início constatamos que é preciso relativizar o uso e as expressões "estilo brasileiro" ou "modelo brasileiro puro" que foram empregadas e reconhecidas, respectivamente pelos publicitários Ricardo Ramos e Caio A. Domingues, quando a propaganda norte-americana ainda não havia sido instaurada em nosso meio publicitário. Caso não o façamos, pode parecer que desprezamos essa produção sugerida como uma autêntica “escola local”. Se, por um lado, concordarmos que o "estilo brasileiro" se identifica com a irreverência e o humor proporcionados tanto pelos poetas quanto pelos caricaturistas e ilustradores, por outro lado, discordamos, quando não se leva em conta o fato da nossa propaganda dos anos 1910-1920 estar impregnada pelo estilo do movimento Art Nouveau. E, conforme apontamos em Propaganda BRASILEIRA NOS ANOS 1920-40, os publicitários diluem a importância da imagem publicitária em suas historiografias, o que implica em conclusões generalizadas. Desse modo, esclarecemos que não reconhecendo nessa produção visual um "modelo brasileiro puro”, não julgamos necessário estudá-la separadamente, ao contrário, seus exemplos fizeram parte do conjunto das peças publicitárias dos caricaturistas e/ou ilustradores que foram selecionadas para as análises críticas. E, por fim, no que se refere à contribuição dos poetas, outros autores já se dedicaram ao assunto, os quais constam de COMPOSIÇÕES ENTRE O LÁPIS E A PENA NA PROPAGANDA BRASILEIRA.

Tendo em conta dois fatores - a constatação da existência de uma produção publicitária comercial (anúncios, cartões postais, rótulos, cartazes e projetos cartazísticos) elaborada por artistas plásticos e a identificação dessa contribuição em sua maioria com os atores de "segunda linha”, - determinamos que os campos estético e artístico seriam os dois eixos analíticos eleitos para conduzir o estudo, visto que, somente um ou outro seria incapaz de dar suporte teórico à esse quadro e as suas particularidades.

Decerto, no período em questão, a publicidade comercial desapropria o artista plástico de sua obra e não o consagra, seja por promover um deslocamento de valia da obra/artista para o produto/fabricante, seja por ser uma produção exterior aos espaços artísticos convencionais da época. A “instituição artística” ignora essa produção, 
relegando-a ao nível da arte menor, pois a publicidade não dispõe de um status artístico embasado nos princípios da arte maior. Talvez, daí decorra, dentre outros motivos, o pouco interesse dos nossos artistas de primeira linha pelo trabalho direto com a publicidade, seja também e até mesmo como um possível meio fomentador de idéias criativas para serem pensadas e levadas às suas produções artísticas pessoais, conduta contrária àquela que ocorreu no cenário europeu com os artistas das vanguardas artísticas. Essa nossa conclusão também se aplica ao período da arte moderna brasileira, mesmo quando no primeiro modernismo houve por parte de seus agentes um questionamento do sistema de produção artístico-cultural vigente. Em verdade, existia uma defasagem entre o que se propunha e o que efetivamente se podia realizar, tanto no plano estético como no artístico. Parece-nos que se a busca por novas linguagens estéticas procurava distanciar a arte moderna da acadêmica, o que na prática brasileira não ocorreu plenamente; o campo artístico se manteve quase o mesmo para os dois sistemas, pois ele dependia das transformações nas estruturas produtivas e sociais do país, as quais, por sua vez, afetavam o meio cultural determinando a inserção ideológica dos artistas e das suas obras, dos marchands, dos críticos e do público.

Embora não seja tão explícita a tensão entre as artes maiores e menores no sistema artístico nacional, estas eram vistas com reservas, o que pode ser sentido em dois artigos de Mário de Andrade de meados de 1929, que procuram conceituar o artista verdadeiro, um “inventor fatalizado" e, a Arte e a sua função:

O artista, como artista e inventor de obras-de-arte, é mais um escravo de si mesmo, é mais um ser fatalizado que outra coisa. Ele tem que dizer o que sente e não o que deveria sentir [...] Se uma sinceridade existe em Arte, única digna, única indesprezível, única impossível de contrariar sem que a obra se prejudique demais: é a sinceridade de invenção. $\mathrm{O}$ artista pode quando muito melhorar intelectualmente uma invenção, torná-la mais vivaz, mais curiosa, mais bonita, enfim mais essas coisas que contribuem para que esteticamente uma obra de arte interesse aos outros. $^{2}$

Ou ainda, quando o poeta se refere às decorações de Lasar Segall para o salão da sra. Olívia Guedes Penteado:

\footnotetext{
${ }^{2}$ Mário de Andrade, “Táxi: Decorativismo I”, in Telê Porto Ancona Lopez, Mário de Andrade, táxi e crônicas no Diário Nacional, São Paulo: Duas Cidades: Secretaria da Cultura, Ciência e Tecnologia, 1976, p. 139.
} 
Ora em toda criação artística que não seja propriamente arte aplicada, e portanto decorativa por essência, não existe absolutamente um critério decorativo por menor que seja. [...] Se pode reconhecer neles [artistas] o desejo de agir. Se pode reconhecer neles a fatalidade de criar, a obediência a um mandado interior ou a um entusiasmo transitório. E a gente reconhece muito bem que tiveram a intenção de agradar se utilizando da Beleza e de todos ou outros meios artísticos que possuíam pra agradar em relação ao que inventavam. Mas, é justamente esta relação inalienável entre a inspiração livre da Arte desinteressada e os meios de agradar que o artista aceita ou repudia na construção, que distingue essencialmente a intenção de agradar que a obra-de-arte livre tem no seu conceito, da função de agradar que a obra-de-arte decorativa tem no conceito dela também. Uma é desinteressada, outra não é. O artista livre pode até desagradar sem que a obra dele deixe de ser bela, de ser humana e de agradar. [...] Lasar Segall foi quem entendeu muito bem essa diferenciação básica entre o agradável da arte desinteressada e o agradável da arte decorativa, quando abandonou todos os seus elementos de criação artística (em abandonar a sua personalidade, está claro), e inventou outros, absolutamente novos nele, pra decorar o salão da sra. Guedes Penteado, aqui em S. Paulo. ${ }^{3}$

O posicionamento de Mário de Andrade nos faz indagar sobre os cartazetes de Fulvio Pennacchi. Seria essa sua produção em princípio uma obra de arte de mesmo valor que suas obras não publicitárias, ou pode ser uma obra de arte superior a algumas de suas obras não publicitárias? Como distinguir Pennacchi artista gráfico publicitário do Pennacchi pintor, e de que modo ele reuniu a linguagem artística com a publicitária?

Antes de respondermos a essas questões, consideramos oportuno situar os projetos publicitários pennacchianos na arte publicitária do período conjuntamente àquela por nós localizada e, da qual também consta uma parcela excêntrica à produção copiosa das revistas ilustradas.

Como demonstramos ao longo do estudo, nossa pesquisa trouxe a conhecimento exemplos nos quais a dedicação dos artistas plásticos à publicidade não se configurou como um terreno de predileção, mas, sim de passagens, geralmente mobilizadas por interesses financeiros ou pela divulgação de empreendimentos pessoais. Essas aventuras “extra-artísticas” estão muitas vezes associadas aos envolvimentos diretos de seus criadores com as próprias revistas que veiculavam as suas matérias comerciais, o que configura uma situação bastante particular. Entretanto, um maior número de peças publicitárias se encontra na esfera da imprensa ilustrada e evoca os traços dos ilustradores e caricaturistas, os quais constituíram um grupo bem sucedido que edificou

\footnotetext{
${ }^{3}$ Mário de Andrade, “Táxi: Decorativismo II”, in idem, pp. 141-142.
} 
um campo artístico próprio e marginal ao das belas artes. Ainda dentro dessa estrutura é importante relembrar que as revistas ilustradas da cidade do Rio de Janeiro tinham empresários como seus diretores, enquanto as de São Paulo, com perfil cultural mais erudito, dispunham dos artistas e literatos, sem contar com os distintos alcances desses periódicos.

Basicamente, vimos que os núcleos de produção artística publicitária vinculamse às cidades do Rio de Janeiro e de São Paulo. Na primeira predomina o desenho disciplinado decorrente de uma profissionalização comprometida com a imprensa ilustrada ou mesmo com os ateliês prestadores de serviços à publicidade; na segunda, os artistas têm atividades diversificadas, voltadas à pintura, à gravura, à arquitetura, à escultura, entre outras, de modo que a publicidade como um espaço de investigação, permitiu, mas não necessariamente absorveu, os exercícios de criação mais inovadores e livres, a exemplo dos trabalhos de Flávio de Carvalho, Pennacchi e de Guilherme de Almeida, na revista Klaxon.

Do primeiro núcleo, excluindo as caricaturas que travam um diálogo criativo com o momento presente e investem na forma sintética, a grande maioria das ilustrações dos herdeiros do traço corresponde a peças publicitárias que não renovaram propriamente a linguagem plástica artística, pois além de se manterem presas a uma criação de fundo mimético, eram guiadas por uma preocupação maior em conjugar os clichês publicitários às técnicas pouco flexíveis do desenho de imprensa, que privilegia a economia de meios, a utilização do preto e do branco do papel, os fundos em degrades e os efeitos da trama.

Conforme apontamos em EvOLUÇÃo DOS ANÚNCIOS COMERCIAIS existe uma convivência de diversos estilos artísticos nas peças publicitárias do período, sendo que muitas delas eram adaptações de material publicitário estrangeiro. Do conjunto que sujeitamos às análises, identificamos, no geral, três situações, duas delas que podem constituir dois extremos: tem-se de um lado, a fase dos reclames com profissionais amadores, entre eles ilustradores e caricaturistas publicando seus trabalhos em revistas ilustradas, e, num pólo oposto, a publicidade técnica e racional, exemplos como o de erico e Ortofh, que publicam em revistas especializadas ou de grande circulação. Diante dessa constatação, onde situar a produção dos outros artistas plásticos, como Di Cavalcanti, Pennacchi, Paim Vieira, Visconti, Flávio de Carvalho, Vicente do Rego Monteiro? 
Por conta dessa última produção circular em revistas de enfoque artísticocultural, de alcance e interesse restritos e elitizados, e muitos projetos não serem executados, consideramos essa terceira vertente como uma produção praticamente independente do meio publicitário, a exceção de Di Cavalcanti. Houve a intenção, como no caso de Pennacchi e Visconti de torná-las públicas, mas, infelizmente, os artistas não obtiveram êxito.

No que concerne aos aspectos estilísticos das peças de nossos artistas plásticos, gráficos e publicitários que realmente foram incorporadas à cultura visual do período, no geral, encontram-se anúncios comerciais filiados à caricatura e à ilustração, com presença dos estilos Art Nouveau e Art Déco, e também às pesquisas tipográficas e às novas relações entre o texto e a imagem. Nesse particular, os exemplos de erico se sobressaem e também se verificam em seus cartazes; e nestes, se notam ainda um diálogo com as tendências construtivistas derivadas do cubismo.

A despeito das questões que deixamos suspensas, acreditamos que não podemos submeter a publicidade aos mesmos critérios requeridos pela arte maior. O cotejamento entre os campos artístico e estético nos adverte que uma classificação hierárquica não está diretamente relacionada, ou melhor, não pode ser confundida, com critérios estéticos ou com as propriedades artísticas do objeto em questão. A publicidade pode ser criada tendo como referência um gênero instituído, no caso a pintura, mas não necessariamente precisa funcionar como obra de arte. Tradicionalmente, se existe uma hierarquia entre a arte e a publicidade, nos parece que é devida às suas diferenças de finalidades, que nesta se resumem a vender ou persuadir em função de interesses comerciais ou de outras naturezas e, que acabam por afetar o seu conteúdo, ao contrário do que sucede com a obra de arte. Essa diferença de objetivos e de eficácia que não contam para a obra de arte, por sua vez, configura-se como uma desvantagem para a publicidade, que, mesmo podendo ter uma qualidade artística elevada, não alcança o status de obra de arte.

Acreditamos que os cartazetes de Pennacchi em sua maioria têm o mesmo valor de suas obras artísticas e muitas de suas composições superam algumas de suas obras não publicitárias. Em relação à distinção entre Pennacchi artista gráfico publicitário e Pennacchi pintor, resulta-nos que eles são bastante próximos, sobretudo pelo acentuado interesse do artista pelo cartaz, o qual pode ser entendido como uma relação de deferência à pintura, que opera como um tipo de hierarquia entre os meios e as técnicas. Os cartazetes pennacchianos ligam-se à tradição cartazística européia e se apresentam 
como mais artísticos do que publicitários, frente à linguagem publicitária dos anos 30, e sobremaneira se distanciam dos padrões técnicos americanos. Desse modo, a nosso ver, o artista não domina, como um erico o faz, a conjunção entre a linguagem artística e a publicitária, pois este demonstra estar mais informado sobre a arte publicitária do período, e, consequentemente sobre o cartaz técnico, principalmente pelo emprego da linguagem construtiva que segue os modelos bauhausianos e pelo conhecimento da produção dos cartazistas franceses. Porém, se de um lado, erico é mais funcional aos objetivos da publicidade, Pennacchi é mais afinado à linguagem estilística moderna versada também numa crítica à modernidade.

Se os trabalhos de Pennacchi viessem a público, não só a nossa publicidade, mas também o meio artístico paulistano teriam sidos contemplados com proposições artísticas mais inovadoras, atualizadas e modernas. Sem dúvida, seria uma produção que se sobressairia da pasteurizada publicidade que se inicia sua consolidação a partir dos anos 30 .

Trazendo para um público mais amplo uma estética moderna que, dificilmente, poderia ser aceita e compreendida dentro do circuito artístico, haja vista as orientações estilísticas adotadas pela maioria de nossos artistas, que transitavam numa modernidade composta de ortodoxias, ressaltamos a importância do papel da publicidade como meio de divulgação de estilos artísticos. Mas se, no caso brasileiro, é inegável a circulação de modelos estrangeiros importados pela publicidade, devemos reconhecer que é através desse mecanismo que ela possibilitou à sociedade, e não somente as elites culturais, a apresentação, o acesso e a legitimação das correntes artísticas modernas, ainda que de modo menos chocante, indireto e adaptado, deglutido como afirma Décio Pignatari.

Ao incluir a publicidade como um agente mediador de valores plásticos e formador de uma cultura visual, Diálogo entre as Artes Plásticas e a Publicidade no BRASIL contribui para alargar o âmbito da historiografia artística brasileira. 


\section{BI BLI OGRAFI A}


1. GERAL

Livros

- Alvim, Zuleika; PeIrÃo, Solange. Mappin setenta anos. São Paulo: Ed. ExLibris, 1985.

- Amaral, A. Aracy (org.). Tarsila cronista. São Paulo: Editora da Universidade de São Paulo, 2001.

- _ _ _ _ Artes plásticas na semana de 22. 5ª̣ ed. São Paulo: Ed. 34, 1998.

- _ (org.). Arte construtiva no Brasil: coleção Adolpho Leirner. São Paulo: Melhoramentos: DBA Artes Gráficas, 1998.

- _ _ _ Artes plásticas na semana de 22. $4^{\underline{a}}$ ed. São Paulo: Perspectiva, 1979.

- Amorim, Sônia Maria de. Em busca de um tempo perdido: edição de literatura traduzida pela Editora Globo (1930-1950). São Paulo: Editora da Universidade de São Paulo: Com-Arte; Porto Alegre: Editora da Universidade UFRGS, 1999.

- Azevedo, Carmem Lucia de. Monteiro Lobato: furacão na Botocúndia. São Paulo: SENAC São Paulo, 1997.

- BAHIA, Juarez. Jornal, história e técnica: história da imprensa brasileira. $4^{\mathrm{a}}$ ed. São Paulo: Ática, 1990.

- Barbosa, Ana Mãe T. B. Arte-educação no Brasil: das origens ao modernismo. São Paulo: Perspectiva, 1978.

- BARdi, P. M. O modernismo no Brasil. São Paulo: Banco Sudameris Brasil S.A., v. 1, 1982.

- Baudelaire, Charles. O pintor da vida moderna. Lisboa: Veja, 1993.

- _ _ Escritos sobre arte. São Paulo: Imaginário: Editora da Universidade de São Paulo, 1991.

- Bolle, Willi. “A cidade como escrita”. In: SÃo PaUlo (CIDAde) Secretaria Municipal de Cultura Departamento do PATRIMÔNIO HistóRICO. O direito à memória: patrimônio histórico e cidadania. São Paulo: Departamento do Patrimônio Histórico, 1992, pp. 137-143.

- BRITO, Mário da Silva (introd.). Klaxon: mensageiro de arte moderna. São Paulo: Livraria Martins Editora, 1972. Edição fac-símile.

- Cauquelin, Anne. Arte contemporânea: uma introdução. São Paulo: Martins, 2005.

- Cendrars, Blaise. Aujourd'hui 1917-1929 suivi d'essais et réflexions 19101916. Paris: Denoël, 1987.

- Costa, Angyone. Inquietação das abelhas. Rio de Janeiro: Pimenta de Mello \& Cia, 1927. 
- Cruz, Heloisa de Faria. São Paulo em papel e tinta: periodismo e vida urbana - 1890-1915. São Paulo: Educ: Fapesp: Arquivo do Estado de São Paulo: Imprensa Oficial do Estado de São Paulo, 2000.

(org.). São Paulo em revista: catálogo de publicações da imprensa cultural e de variedades paulistana 1870-1930. São Paulo: Arquivo do Estado, 1997.

- DORfles, Gillo. Le oscillazioni del gusto: l'arte d'oggi tra tecnocrazia e consumismo. Torino: Einaudi, 1977.

- Duarte, Paulo. História da imprensa em São Paulo. São Paulo: Escola de Comunicações e Artes da Universidade de São Paulo, 1972.

- Dufrenne, Mikel; Formaggio, Dino. Trattato di estetica. Milano: Mondadori, v.2, 1981.

- Durand, José Carlos. Arte, privilégio e distinção: artes plásticas, arquitetura e classe dirigente no Brasil 1855/1985. São Paulo: Perspectiva: Editora da Universidade de São Paulo, 1989.

- DuQue, Gonzaga. Contemporâneos (pintores e esculptores). Rio de Janeiro: Typ. Benedicto de Souza, 1929.

- Fabris, Annateresa; Zimmermann, Silvana Brunelli. Arte moderna. São Paulo: Experimento, 2001.

- FABRIS, Annateresa. Fragmentos urbanos: representações culturais. São Paulo: Studio Nobel, 2000.

- FONSECA, Joaquim da. Caricatura: a imagem gráfica do humor. Porto Alegre: Artes e Ofícios, 1999.

- Guelfi, Maria Lúcia Fernandes. Novíssima: estética e ideologia na década de vinte. São Paulo: Instituto de Estudos Brasileiros da Universidade de São Paulo, 1987.

- HAuSER, Arnold. Introduccion a la historia del arte. Madrid: Ediciones Guadarrama, 1961.

- Indústria farmacêutica e cidadania: ABIFARMA 50 anos: 1947-1997. São Paulo: ABIFARMA - Associação Brasileira da Indústria Farmacêutica, 1997.

- IVINS JR. N. M. Imagen impresa y conocimiento: análisis de la imagen prefotográfica. Barcelona: Gustavo Gili, s.d.

- Janovitch, Paula Ester. Preso por trocadilho: a imprensa de narrativa irreverente paulistana 1900-1911. São Paulo: Alameda, 2006.

- Lima, Herman. História da caricatura no Brasil. Rio de Janeiro: José Olympio Editora, 4 v., 1963.

- Lopez, Telê Porto Ancona. Mário de Andrade táxi e crônicas no Diário Nacional. São Paulo: Duas Cidades: Secretaria da Cultura, Ciência e Tecnologia, 1976.

- Lourenço, Maria Cecília França. Operários da modernidade. São Paulo: Hucitec: Editora da Universidade de São Paulo, 1995. 
- Lyotard, Jean-François. Moralidades pós-modernas. Campinas: Papirus, 1996.

- MAgritTe, René. Écrits complets. Paris: Flammarion, 1979.

- MALDONADO, Tomás. Vanguardia y racionalidad: artículos, ensayos y otros escritos: 1946-1974. Barcelona: Gustavo Gili, 1977.

- MARAnhão, Ricardo (coord.). Um retrato no jornal: a história de São Paulo na imprensa oficial (1891-1994). São Paulo: Imprensa Oficial do Estado, 1994.

- Martins, Ana Luiza. Revistas em revista: imprensa e práticas culturais em tempos de república, São Paulo (1890-1922). São Paulo: Editora da Universidade de São Paulo: Fapesp: Imprensa Oficial do Estado de São Paulo, 2001.

- Meyer, Marlyse (org.). Do almanak aos almanaques. São Paulo: Ateliê Editorial, 2001.

- Miceli, Sergio. Nacional estrangeiro: história social e cultural do modernismo artístico em São Paulo. São Paulo: Companhia das Letras, 2003.

- _ _ Intelectuais à brasileira. São Paulo: Companhia das Letras, 2001.

- _ Imagens negociadas: retratos da elite brasileira (1920-40). São Paulo: Companhia das Letras, 1996.

- Morais, Frederico. Cronologia das artes plásticas no Rio de Janeiro 18161994. Rio de Janeiro: Topbooks, 1995.

- PARK, Margareth Brandini. Histórias e leituras de almanaques no Brasil. Campinas: Mercado de Letras: Associação de Leitura do Brasil; São Paulo: Fapesp, 1999.

- Pevsner, Nikolaus. Academias de arte: passado e presente. São Paulo: Companhia das Letras, 2005.

- PignatARi, Décio. Signagem da televisão. São Paulo: Brasiliense, 1984.

- Pinacoteca do Estado. Catálogo geral de obras. São Paulo: Secretaria do Estado da Cultura: minC: IMESP: DEMA: Pinacoteca do Estado, 1988.

- ReIs JR., José Maria dos. “Carlos Oswald, Raimundo Cela, Oswaldo Goeldi”. In: SouZA, Wladimir Alves de et alii. Aspectos da arte brasileira. Rio de Janeiro: FUNARTE, 1980, pp. 96-108.

- RoQue, Georges (org.). Majeur ou mineur?: les hiérarchies en art. Nîmes: Éditions Jacqueline Chambon, 2000.

- _ Ceci n’est pas um Magritte: essai sur Magritte et la publicité. Paris: Flammarion, 1983.

- SCARINCI, Carlos. A gravura no Rio Grande do Sul 1900-1980. Porto Alegre: Mercado Aberto, 1982.

- Sevcenko, Nicolau. Literatura como missão: tensões sociais e criação cultural na primeira república. $2^{\underline{a}}$ ed. São Paulo: Companhia das Letras, 2003.

- _org.). História da vida privada no Brasil: República: da Belle Époque à era do rádio. São Paulo: Companhia das Letras, v. 3, 1998. 
- Sodré, Nelson Werneck. História da imprensa no Brasil. Rio de Janeiro: Civilização Brasileira, 1966.

- Squeff, Letícia. O Brasil nas letras de um pintor: Manuel de Araújo Porto Alegre (1806-1879). Campinas: Editora da UNICAMP, 2004.

- SüsseKIND, Flora. Cinematógrafo de letras: literatura, técnica e modernização no Brasil. São Paulo: Companhia das Letras, 1987.

- VARNEDOE, Kirk; GOPNIK, Adam. Modern art and popular culture: readings in high \& low. New York: The Museum of Modern Art: Harry N. Abrams, 1990.

- High \& Low: modern art and popular culture. New York: The Museum of Modern Art, 1990.

- Velloso, Mônica Pimenta. Modernismo no Rio de Janeiro: turunas e quixotes. Rio de Janeiro: Editora Fundação Getulio Vargas, 1996.

Dicionários

- Cavalcanti, Carlos (org.) Dicionário brasileiro de artistas plásticos. Brasília: Instituto Nacional do Livro: Ministério da Educação e Cultura, 4 v., 1973.

- Cury, Constantino. Dicionário de artistas plásticos brasileiros. São Paulo: Cury Arte Brasil, 2005.

- Louzada, Júlio. Artes plásticas: seu mercado, seus leilões. São Paulo: Júlio Louzada, 1984.

- Pontual, Roberto. Dicionário de artes plásticas no Brasil. Rio de Janeiro: Civilização Brasileira, 1969.

- RabaçA, Carlos Alberto; Barbosa, Gustavo Guimarães. Dicionário de comunicação. São Paulo: Editora Ática, 1987.

Periódicos (revistas e jornais)

- Bourdieu, Pierre. "L'illusion biographique”. Actes de la Recherche en Sciences Sociales, Paris, (62-63): 69-72, juin 1986.

- Cunha, Luiz Antônio. “O ensino industrial-manufatureiro no Brasil”. Revista Brasileira de Educação, São Paulo, (14): 89-107, maio - ago. 2000.

- Roque, Georges. “Quand le mineur critique le majeur”. Artpress, Paris, (266): 28-33, mars 2001. 
Inéditos

- Abdelmalack, Genny. Momentos da história do Brasil através da caricatura 1900-1937. São Paulo: Escola de Comunicações e Artes da Universidade de São Paulo, 1991. Dissertação de mestrado.

- Cantarelli, Ligia Cosmo. A Belle Époque da editoração brasileira: um estudo sobre a estética Art Nouveau nas capas de livros do início do século XX. São Paulo: Escola de Comunicações e Artes da Universidade de São Paulo, 2006. Dissertação de mestrado.

- Fontana, Carla Fernanda. O ateliê de desenho da Livraria do Globo. São Paulo: Escola de Comunicações e Artes da Universidade de São Paulo, 2004. TCC - Departamento de Jornalismo e Editoração.

- Ramos, Paula Viviane. A experiência da modernidade na Secção de Desenho da Editora Globo. Revista do Globo (1929-1939). Porto Alegre: Instituto de Artes da Universidade Federal do Rio Grande do Sul, 2002. Dissertação de mestrado.

- Simioni, Ana Paula Cavalcanti. Das belas-artes às artes aplicadas: a experiência suíça de Regina Gomide Graz (1913-1920). São Paulo: XXVI Colóquio do Comitê Brasileiro de História da Arte, 2006.

\section{PUBLICIDADE EM GERAL}

Livros

- BAudrillard, Jean. "Significação da publicidade". In: LiMA, Luiz Costa. Teoria da cultura de massa. Rio de Janeiro: Paz e Terra, 1978, pp. 271-280.

- Berger, John et alii. Modos de ver. São Paulo: Martins Fontes, 1987.

- Carvalho, Nelly de. Publicidade: a linguagem da sedução. $3^{\underline{a}}$ ed. São Paulo: Ática, 2001.

- Cornu, Geneviève. Sémiologie de l'image dans la publicité. Paris: Les Éditions d’ Organisation, 1992.

- Durand, Jacques. Retórica e imagem publicitária. In: Metz, Christian et alii. A análise das imagens. Petrópolis: Vozes, 1973, pp. 19-59.

- Joly, Martine. Introducción al análisis de la imagen. Buenos Aires: Biblioteca de la Mirada, 1999.

- Sandmann, Antônio. A linguagem da propaganda. $6^{\mathrm{a}}$ ed. São Paulo: Contexto, 2001. 
Livros

- 150 ans de publicité: collections du musée de la publicité. Paris: Union Centrale dés Arts Décoratifs, 2004.

- Centre Georges Pompidou. Art \& Pub: art et publicité 1890-1990. Paris: Éditions du Centre Georges Pompidou, 1990.

- CHEssel, Marie-Emmanuelle. La publicité: naissance d'une profession 19001940. Paris: Éditions CNRS, 2002.

- FOX, Stephen. The mirror makers: a history of American advertising and its creators. Chicago: Illini Books, 1997.

- Gauli, Juan Carlos Pérez. El cuerpo em venta: relación entre arte y publicidad. Madrid: Cátedra, 2000.

- Grazioli, Elio. Arte e pubblicità. Milano: Bruno Mondadori, 2001.

- GuZMÁn, José Ramón Sánchez. Breve historia de la publicidad. $2^{\mathrm{a}}$ ed. Madrid: Ediciones Forja, 1982.

- Holme, Bryan. Advertising: reflections of a century. New York: The Viking Press, 1982.

- LANCELlotTI, Arturo. Storia aneddottica della réclame. Milano: Dr. R. Quintieri Editore, 1912.

- PUIG, Jaime P. La publicidad: historia y tecnicas. Barcelona: Editorial Mitre, 1986.

\section{PUBLICIDADE BRASILEIRA}

Livros

- Accioly, Anna et alii. Marcas de valor no mercado brasileiro. Rio de Janeiro: Ed. Senac Rio, 2003.

- Associação Paulista de Propaganda. Depoimentos. São Paulo: Associação Paulista de Propaganda, 1973.

- Branco, Renato Castelo et alii. História da propaganda no Brasil. São Paulo: T. A. Queiroz, 1990.

- Cadena, Nelson Varón. Brasil - 100 anos de propaganda. São Paulo: Edições Referência, 2001.

- 450 anos de propaganda na Bahia. Salvador: Associação Comercial da Bahia: Shopping Barra, 1998-1999. 
- Carvalho, Ernani Macedo de. Publicidade e propaganda. $2^{a}$ ed. São Paulo: Ed. Atlas, 1947.

- Castro, Maria Helena Steffens de. O literário como sedução: a publicidade na Revista do Globo. Porto Alegre: EDIPUCRS, 2004.

- 100 anos de propaganda. São Paulo: Abril Cultural, 1980.

- Gessy Lever: história e histórias de intimidade com o consumidor brasileiro. São Paulo: Unilever, 2001.

- Gracioso, Francisco; Penteado, J. Roberto Whitaker. Propaganda brasileira. São Paulo: Mauro Ivan Marketing Editorial, 2004.

- _ Cinqüenta anos de vida e propaganda brasileiras. São Paulo: Mauro Ivan Marketing Editorial, 2001.

- KlintowitZ, Jacob. A arte do comércio II: São Paulo 1930 - 1954. São Paulo: SENAC, 1989.

- _ A arte do comércio I: São Paulo 1900 - 1930. São Paulo: SENAC, 1988.

- MARCOndes, Pyr. Uma história da propaganda brasileira. Rio de Janeiro: Ediouro, 2001.

- Martensen, Rodolfo Lima. Desafio de quatro santos: memórias. São Paulo: LR Editores, 1983.

- Nunes, Pedro. 35 anos de propaganda. Rio de Janeiro: Gernasa, s.d.

- Oberlaender, Ricardo. História da propaganda no Brasil. Rio de Janeiro: Shogun Arte, 1984.

- 80 anos construindo o futuro: Rhodia Farma 80 anos: 1919-1999. São Paulo: Museu da Pessoa, 1999.

- Padilha, Márcia. A cidade como espetáculo: publicidade e vida urbana na São Paulo dos anos 20. São Paulo: Annablume, 2001.

- RABELO, Genival. Os tempos heróicos da propaganda: agências pioneiras. Rio de Janeiro: Empresa Jornalística PN S/A, 1956.

- RAmos, Ricardo. Do reclame à comunicação: pequena história da propaganda no Brasil. $3^{\underline{a}}$ ed. São Paulo: Atual, 1985.

- _ Um estilo de propaganda. São Paulo: CBBA, 1983.

- _ _ _ _ MARCONDES, Pyr. 200 anos de propaganda no Brasil: do reclame ao cyber-anúncio. São Paulo: Meio \& Mensagem, 1995.

- Reclames da Bayer 1911-1942. São Paulo: Bayer do Brasil S.A., 1986.

- Yves, Pedro. Annuncios paulistanos. São Paulo: Editora Referência, 2004. 
Periódicos (revistas e jornais)

- “A publicidade no Brasil”. O Observador: econômico e financeiro, Rio de Janeiro, 1 (12): 41-52, jan. 1937.

- About, São Paulo, (628), 21 maio 2001.

- Abreu, Alzira Alves de. “A alma do negócio”. Nossa História, Rio de Janeiro, (23): 36-42, set. 2005.

- base: revista de arte, técnica e pensamento, Rio de Janeiro, (3), out. 1933. Número especial sobre propaganda.

- BidarRA, Clemara. “A propaganda e Machado: donos do próprio nariz”. FACOM, São Paulo, (14): 11-14, $1^{0}$ sem. 2005.

- CRuz, Heloísa de Faria. “A cidade do reclame: propaganda e periodismo em São Paulo - 1890/1915”. Projeto História, São Paulo, (13): 81-92, jun. 1996.

- DANIEL, Érica Gomes. "Nos intervalos da guerra: pan-americanismo e propaganda comercial no Brasil dos anos 40”. Revista da ESPM, São Paulo, 10 (1): 44-55, jan. - fev. 2003.

- Domingues, Caio A. "Modelo brasileiro de propaganda”. Propaganda, São Paulo, XVII (208): 33-40, nov. 1973.

- Geni, Marcondes. “A cidade pelo anúncio: 150 anos de compra e venda”. O Cruzeiro, São Paulo, (s.n.): 110-114, nov. 1965. Edição Comemorativa do IV Centenário.

- Lessa, Orígines. "Hall da fama”. Propaganda, São Paulo, (266): 68-89, set. 1978.

- “O dezenho em função da publicidade na imprensa moderna”. Publicidade, Rio de Janeiro, (s.n.): 13, 26-27, set. 1940.

- Ramos, Ricardo. "Um século de propaganda no Brasil”. O Estado de S. Paulo, (51): 3, 20 dez. 1975. Suplemento do Centenário.

- “Salão de propaganda”. Habitat, São Paulo, (2): 44-50, jan. - mar. 1951.

- SIMÕEs, Roberto. “História da propaganda brasileira”. Propaganda, São Paulo, 26 (308): 40-124, fev. 1982.

- Zimmermann, Silvana Brunelli. "Reclames testemunhais”. Mimesis: ciências humanas, Bauru, 26 (2): 55-74, 2005.

Inéditos

- Held, Maria Sílvia Barros de. Considerações plásticas sobre “Art Nouveau” nos anúncios publicitários ilustrados do início do século XX em São Paulo. São Paulo: Escola de Comunicações e Artes da Universidade de São Paulo, 1981. Dissertação de mestrado.

- História da publicidade 1808/1980-1986 e Quadro histórico de publicidade. São Paulo: Centro Cultural São Paulo - Divisão de Pesquisa, s.d. 
- SUTTI, Paulo. O reclame: a transição da reprodutibilidade persuasiva. São Paulo: Pontíficia Universidade Católica de São Paulo, 1996. Dissertação de mestrado.

- TADDEI, Maria Diva Vasconcelos. A imagem no anúncio de jornal 1850-1914. São Paulo: Faculdade de Arquitetura e Urbanismo da Universidade de São Paulo, 1977. Dissertação de mestrado.

- Temin, Wilma Ruth. A identidade visual do Mappin uma trajetória de 85 anos. São Paulo: Faculdade de Arquitetura e Urbanismo da Universidade de São Paulo, 1999. Dissertação de mestrado.

- Trusz, Alice Dubina. A publicidade nas revistas ilustradas: o informativo cotidiano da modernidade. Porto Alegre - Anos 20. Porto Alegre: Instituto de Filosofia e Ciências Humanas da Universidade Federal do Rio Grande do Sul, 2002. Dissertação de mestrado.

- WilKe, Regina Cunha. Comunicação visual do anúncio publicitário: uma análise interpretativa da mensagem estética. São Paulo: Faculdade de Arquitetura e Urbanismo da Universidade de São Paulo, 1998. Dissertação de mestrado.

Documentos

- Elementos de propaganda, s.l. s.d. Texto datilografado, localizado na Biblioteca e Centro de Documentação do Museu de Arte de São Paulo Assis Chateaubriand.

\section{DESIGN GRÁFICO EM GERAL}

Livros

- A revista no Brasil. São Paulo: Editora Abril, 2000.

- ACHA, Juan. Introducción a la teoria de los diseños. México: Editorial Trillas, 1988.

- Barnicoat, John. Histoire concise de l'affiche. Paris: Librairie Hachette, 1972.

- Camargo, Mário de (org.). Gráfica: arte e indústria no Brasil: 180 anos de história. 2 ${ }^{a}$ ed. São Paulo: Bandeirantes Gráfica, 2003.

- CARdoso, Rafael (org.). O design brasileiro antes do design: aspectos da história gráfica, 1870-1960. São Paulo: Cosac Naify, 2005.

- Denis, Cardoso Rafael. Uma introdução à história do design. São Paulo: Edgard Blücher, 2000. 
- ENEL, Françoise. El cartel: lenguaje, funciones, retorica. Valencia: Fernando Torres Editor, 1974.

- FERREIRA, Orlando da Costa. Imagem e letra: uma introdução à bibliologia brasileira: a imagem gravada. $2^{\underline{a}}$ ed. São Paulo: Editora da Universidade de São Paulo, 1994.

- Gallo, Max. L'affiche miroir de l'histoire: miroir de la vie. Paris: Laffont, 1974.

- GaudÊnCio Junior, Norberto. A herança escultórica da tipografia. São Paulo: Rosari, 2004.

- GLUCK, Felix. World graphic design: fifty years of advertising art. London: Studio Vista; New York: Watson Guptill Publications, 1968.

- Gorberg, Samuel. A propaganda no Brasil através do cartão postal: 19001950. Rio de Janeiro: S. Gorberg, 2002.

- Gráfica Utópica - arte gráfica russa 1904-1942. São Paulo: Centro Cultural Banco do Brasil, 2001.

- História da tipografia no Brasil. São Paulo: Museu de Arte de São Paulo, 1979.

- Hollis, Richard. Design gráfico: uma história concisa. São Paulo: Martins Fontes, 2001.

- KerY, Patricia Frantz. Art deco graphics. New York: Thames \& Hudson Inc., 2002.

- Le Coultre, Martijn F. \& Purvis, W. Alston. Un siglo de carteles. Barcelona: Gustavo Gili, 2003.

- LiMA, Yone Soares de. A ilustração na produção literária: São Paulo década de vinte. São Paulo: Instituto de Estudos Brasileiros da Universidade de São Paulo, 1985.

- Lo DuCA. L’affiche. Paris: Presses Universitaires de France, 1945.

- MenegazzI, Luigi. Il manifesto italiano 1882-1925. Milano: Electa Editrice, s.d..

- Mitologia e iconografia del XX secolo nel manifesto italiano dal 1895 al 1914. Roma: De Luca, 1979.

- Moles, Abraham. O cartaz. São Paulo: Perspectiva, 1987.

- MunARI, Bruno. Artista y designer. Valencia: Fernando Torres Editor, 1974.

- NeumanN, Eckhard. "Le graphisme fonctionnel: entre les nouvelles conceptions artistiques et les besoins de la société industrielle”. In: Hulten, Pontus (org.)

Paris, Berlin: rapports et contrastes france-allemagne, 1900-1933 art, architecture, graphisme, littérature, objets industriels, cinéma, théâtre, musique. Paris: Centre National d'Art et de Culture Georges Pompidou, 1978, pp. 396-409.

- O desenho industrial no Brasil: ensino e mercado de trabalho. Rio de Janeiro: Mudes-Ilari, 1970. 
- Panorama do design gráfico brasileiro contemporâneo. São Paulo: Câmara Brasileira do Livro, 1994.

- PICA, Vittorio. Il manifesto: arte e comunicazione nelle origini della pubblicità. Napoli: Liguori, 1994.

- Ripert, Aline; Frère, Claude. La carte postale: son histoire, sa fonction sociale. Paris: Editions du CNRS; Lyon: Presses Universitaires de Lyon, 1983.

- Rossi, Attilio. Posters. London: Paul Hamlyn, 1969.

- SAtuÉ, Enric. El diseño gráfico: desde los orígenes hasta nuestros días. Madrid: Alianza Editorial, 1992.

- V. A. Quand l'affiche faisait de la réclame! L'affiche française de 1920 à 1940. Paris: Edition de la Reúnion des Musées Nationaux, 1991.

- WeILl, Alain. L’affiche française. Paris: Presses Universitaires de France, 1982.

- Willoughby, Martin. História do bilhete-postal. Lisboa: Caminho, 1993.

- Wollner, Alexandre. “Comunicação visual”. In: ZANini, Walter. História geral da arte no Brasil. São Paulo: Instituto Walther Moreira Salles: Fundação Djalma Guimarães, v. II, 1983, pp. 953-971.

Periódicos (revistas e jornais)

- Angelini, Mario. “História da publicidade: 'VIII - histórico do cartaz””. Publicidade, Rio de Janeiro, VI (64): 14-16, ago. 1946.

- _ "História da publicidade: "V evolução dos veículos de publicidade"”. Publicidade, Rio de Janeiro, VI (59): 26, 27 e 31, mar. 1946.

- Araújo, Olívio Tavares de. “O outro espetáculo: 'posters' e cartazes de teatro, de 1917 até hoje”. Isto É, São Paulo, (266): 3, 27 jan. 1982.

- CAmpofiorito, Quirino. "Artes industriais e as tradições do ensino artístico no Brasil”. Arquivos da Escola Nacional de Belas-Artes, Rio de Janeiro, (9): 7176, 12 ago. 1963.

- “Cartaz”. Folha de Londrina, 27 mar. 1982.

- “Cerveja em cartaz: uma exposição reúne toda a propaganda da Antarctica em 93 anos, e faz história”. Veja, São Paulo, (810): 120-121, 14 mar. 1984.

- “Exposição de cartazes”. O Malho, Rio de Janeiro, 10 dez. 1932.

- LE Bot, Marc. “Arte/Design”. Malasartes, Rio de Janeiro, (3): 20-24, abr.maio-jun. 1976.

- Lopes, Adélia Maria. “Brasil já tem museu do cartaz”. Em Curitiba. O Estado de S. Paulo, 12 jul. 1981.

- PaIVA, Flávio. “Em cartaz, a história de uma arte impactual”. O Povo, Fortaleza, 24 ago. 1986. 
Inéditos

- Chypriades, Heloísa Dallari. Cartaz: abordagem histórico visual. São Paulo: Faculdade de Arquitetura e Urbanismo da Universidade de São Paulo, 1996. Dissertação de mestrado.

- Martins, Nara Silvia Marcondes. A reinvenção do art déco: design gráfico nos anos 90. São Paulo: Faculdade de Arquitetura e Urbanismo da Universidade de São Paulo, 2000. Tese de doutorado.

- . $\mathrm{O}$ - $\mathrm{O}$ art déco e o poético em cartazes. São Paulo: Instituto de Artes da Universidade Estadual Paulista, 1995. Dissertação de mestrado.

- MirAndA, Evanise Colombini. Gráfica cartazística na sociedade. São Paulo: Faculdade de Arquitetura e Urbanismo da Universidade de São Paulo, 1974. Trabalho de graduação interdisciplinar.

- Vinha, Adriana M. C. Navarro. Cartão postal: cem anos de retrato da cidade de São Paulo, 1897-1997. São Paulo: Faculdade de Arquitetura e Urbanismo da Universidade de São Paulo, 2001. Dissertação de mestrado.

Catálogos

- Associação pró-parque modernista. O bonde, veículo público e publicitário. Texto de Ayrton Camargo e Silva, s.l., s.d.

- British posters 1890-1980. Rio de Janeiro: Solar Grandjean de Montigny, 11 set. - 10 out. 1987.

- Cartazes suiços. São Paulo: Museu de Arte Contemporânea da Universidade de São Paulo, mar. - abr. 1968.

- I Quadrienal de propaganda. São Paulo: Museu de Arte Moderna de São Paulo, 16 out. - 7 nov. 1986.

- O design no Brasil: história e realidade. São Paulo: Museu de Arte de São Paulo Assis Chateaubriand, 1982.

- Perfume e maquilagem numa exposição. São Paulo: Museu de Arte de São Paulo Assis Chateaubriand, 1978.

- Semana de 22: antecedentes e conseqüências. São Paulo: Museu de Arte de São Paulo Assis Chateaubriand, 1972. Exposição comemorativa do cinqüentenário.

- Tempo dos modernistas. São Paulo: Museu de Arte de São Paulo Assis Chateaubriand, ago. - set. 1974. 
Livros

- AREstizÁbAL, Irmã. J. Carlos: cem anos. Rio de Janeiro: FUNARTE: Instituto Nacional de Artes Plásticas: PUC-RJ: Solar Grandjean de Montigny, 1984.

- Barsante, Cássio Emmanuel. Santa Rosa em cena. Rio de Janeiro: Instituto Nacional de Artes Cênicas, 1982.

- Belluzzo, Ana Maria de Moraes. Voltolino e as raízes do modernismo. São Paulo: Marco Zero, 1992.

- Bruscky, Paulo. Vicente do Rego Monteiro poeta, tipógrafo, pintor. São Paulo: Cepe, 2005.

- Cabral, Isabella; Rezende, M. A. Amaral. Hermelindo Fiaminghi. São Paulo: Editora da Universidade de São Paulo, 1998.

- Cotrim, Álvaro. J. Carlos: época, vida, obra. Rio de Janeiro: Nova Fronteira, 1985.

- DAher, Luiz Carlos. Flávio de Carvalho e a volúpia da forma. São Paulo: Edições “K”: MWMotores, 1984.

- Loredano, Cássio. O bonde e a linha: um perfil de J. Carlos. São Paulo: Capivara, 2002.

- Monteiro, Maria Isabel Oswald. Carlos Oswald (1882-1971): pintor da luz e dos reflexos. Rio de Janeiro: Casa Jorge Editorial, 2000.

- Portinari, Cândido. Cândido Portinari: catálogo raisonné. Rio de Janeiro: Projeto Portinari, v. II (1939-1944), 2004, pp. 331-334.

- Ribeiro, Marília Andrés; Silva, Fernando Pedro da. Um século de história das artes plásticas em Belo Horizonte. Belo Horizonte: C/Arte: Fundação João Pinheiro. Centro de Estudos Históricos e Culturais, 1997.

- Simioni, Ana Paula Cavalcanti. Di Cavalcanti ilustrador: trajetória de um jovem artista gráfico na imprensa (1914-1922). São Paulo: Editora Sumaré, 2002.

- Zanini, Walter. Vicente do Rego Monteiro artista e poeta 1899-1970. São Paulo: Empresa das Artes: Marigo Editora, 1997.

Periódicos (revistas e jornais)

- “A história da publicidade: Charlotta Adlerova no MASP”. Diário Popular, São Paulo, 18 mar. 1983.

- “A publicidade, em mãos femininas”. Folha de S. Paulo, 16 mar. 1983.

- “Acquarone premiado e em viagem”. A Noite, Rio de Janeiro, 18 jul. 1958. 
- AlmeidA, Guilherme de. "Um cartaz”. Rio de Janeiro, 30 abr. 1948, p. 3. Recorte de jornal localizado na Divisão de Pesquisa do Arquivo Multimeios da SMC-PMSP do Centro Cultural São Paulo.

- “Alvarus é enterrado no Rio”. Folha de S. Paulo, 16 jul. 1985.

- ANDRADE, Humberto Heitor de. “A arte que eles não fazem (I)”. GAM: Galeria de Arte Moderna, Rio de Janeiro, (11): 31-35, 1968.

- “Ary Fagundes”. Publicidade: Revista Técnica de Propaganda e Vendas, Rio de Janeiro, (11): 24-25, 4 dez. 1941.

- Bellas Artes, Rio de Janeiro, I, (3): 2, mar. 1935.

- “Belmiro, quase desconhecido”. Recorte de jornal localizado no Arquivo Histórico Wanda Svevo da Fundação Bienal de São Paulo.

- “Biografia Danilo Di Prete”. s.l., s.d., p. 22. Recorte de revista localizado na Divisão de Pesquisa do Arquivo Multimeios da SMC-PMSP do Centro Cultural São Paulo.

- “Caricaturas de Belmiro no MAB”. Folha de S. Paulo, 10 jun. 1970.

- “CEF expõe o melhor sobre a vida e obra de Álvarus”. O Fluminense, Niterói, 24 abr. 1988.

- “Charlotta Adlerová - pintora e desenhista de publicidade”. A Gazeta, São Paulo, 11 abr. 1963.

- Coutinho, Wilson. "Visconti, um pioneiro das artes decorativas no Brasil". Jornal do Brasil, Rio de Janeiro, 23 ago. 1983.

- “Em exposição os cartazes do concurso patrocinado pela Divisão do Fomento”. Diário de S. Paulo, 23 nov. 1950.

- Eu Sei Tudo, Rio de Janeiro, $8^{0}$ do $19^{0}$ (224): 4, jan. 1936.

- Eu Sei Tudo, Rio de Janeiro, $8^{0}$ do $18^{0}$ (112): 103, jan. 1935

- LiMA, Yone Soares de. “Homenagem a Paim”. Revista do Instituto de Estudos Brasileiros, São Paulo, (29): 125-141, 1988.

- LOPOnte, J. “Os muitos conflitos da criação". GAM: Galeria de Arte Moderna, Rio de Janeiro, (12): 32-33, 1968.

- Maurício, Jayme. "Do ensino do desenho no Museu de Arte Moderna”. Correio da Manhã. Rio de Janeiro, 4 dez. 1956.

- Mauso, Pablo Villarrubia. “A arte oculta de mestre Paim”. Shopping News, São Paulo, 10 jun. 1970.

- Moraes, Angélica de. "Visconti, um artista até nos rótulos de propaganda”. Zero Hora, Porto Alegre, 19 dez. 1983.

- MorAIs, Frederico. “ 'Eliseu Visconti e a arte decorativa', o resgate de uma obra pioneira”. O Globo, Rio de Janeiro, 16 ago. 1983.

- “O ‘Diário de S. Paulo’ promove um concurso de cartazes”. s.l., ago. 1947, p. 34. Recorte de revista localizado na Divisão de Pesquisa do Arquivo Multimeios da SMC-PMSP do Centro Cultural São Paulo. 
- “O primeiro cartaz digno de ser visto”. Recorte de jornal localizado na Divisão de Pesquisa do Arquivo Multimeios da SMC-PMSP do Centro Cultural São Paulo.

- OnAGA, Hideo. “O pintor sustentado pelo desenhista de modas”. s.l., s.d. Recorte de jornal localizado na Divisão de Pesquisa do Arquivo Multimeios da SMC-PMSP do Centro Cultural São Paulo.

- “Os ítalos e os brasileiros na arte do entre guerras”. Jornal das Exposições Pinacoteca do Estado, São Paulo, 1999.

- Papel e Tinta, São Paulo e Rio de Janeiro, (6): s.p., jan. - fev. 1921.

- Papel e Tinta, São Paulo e Rio de Janeiro, (4): s.p., ago. - set. 1920.

- "Pennacchi: 50 anos de criação na Oscar Seraphico”. Correio Brasiliense, Brasília, 12 jun. 1979.

- "Psiquiatra quando jovem, medalha de ouro para Acquarone”. O Jornal, Rio de Janeiro, 16 fev. 1973.

- Ramos, Paula. "Urbi et orbi”. Museu de Arte do Rio Grande do Sul Ado Malagoli, Porto Alegre, (83): s.p., set. 2002.

- "Santa Rosa professor de desenho de propaganda". Publicidade: Revista de Propaganda e Negócios, Rio de Janeiro, (61): 6, maio 1946.

- SenA, Carla. “A paixão gráfica do mestre Quirino”. O Fluminense, Niterói, 22 set. 1993.

- Silva, Quirino da. “Mick Carnicelli”. Diário de S. Paulo, 2 set. 1962.

- “Stand da S. A. Tubos Brasilit”. Acrópole, São Paulo, (193): 68, out. 1954.

- TARASANTCHI, Ruth Sprung. "Paim um artista nacionalista". Revista do Instituto de Estudos Brasileiros, São Paulo, (29): 101-110, 1988.

- YAmAzAKI, Tizuca. “Orestes Acquarone: nosso embaixador nas artes plásticas”. O Jornal, Rio de Janeiro, 12 nov. 1972.

\section{Catálogos}

- Alvarus. Rio de Janeiro: Caixa Econômica Federal Conjunto Cultural, 20 abr.13 maio 1988.

- Aquarela brasileira. Rio de Janeiro: Centro Cultural Light, 22 maio - 15 jul. 2001.

- Axl Leskoscheck e seus alunos Brasil / 1940-1948. Rio de Janeiro: Museu de Arte Moderna do Rio de Janeiro, s.d.

- Belmonte presente. São Paulo: Museu de Arte de São Paulo Assis Chateaubriand, out. 1978.

- Campofiorito. Rio de Janeiro: Bolsa de Arte do Rio de Janeiro, 16 maio - 8 jun. 1977.

- Di Cavalcanti. São Paulo: Museu de Arte Contemporânea da Universidade de São Paulo, s.d. 
- Edição comemorativa dos quarenta anos de pintura de Fulvio Pennacchi. São Paulo: Museu de Arte de São Paulo Assis Chateaubriand, abr. 1973.

- Eliseu Visconti e a arte decorativa. Rio de Janeiro: PUC/FUNARTE, 1983.

- Exposição Flávio de Carvalho. São Paulo: 17ª̣ Bienal de São Paulo, 1983.

- Fundação Armando Alvares Penteado. A comédia urbana: de Daumier a Porto-Alegre. São Paulo: Museu de Arte Brasileira - Fundação Armando Alvares Penteado, 26 abr. - 22 jun. 2003.

- Jean Pierre Chabloz 1910-1984: pinturas e desenhos. Fortaleza: Galeria Multiarte, 7 maio - 27 jun. 2003.

- Os “reclames” de Fulvio Pennacchi: primórdios da propaganda brasileira. São Paulo: Instituto Moreira Salles, maio 2005.

- Pennacchi 100 anos. São Paulo: Pinacoteca do Estado de São Paulo, maio - jun. 2006.

- Programa do Theatro Municipal. São Paulo: Theatro Municipal, 29 set. 1930.

- Sociedade Symphonica de São Paulo: concerto no 5 . São Paulo: Theatro Municipal, 28 jun. 1930.

Documentos

- Carta manuscrita de Pennacchi. s.l., s.d. Localizada na Biblioteca e Centro de Documentação do Museu de Arte de São Paulo Assis Chateaubriand.

7. POETAS E ESCRITORES

Livros

- Abreu, Arnaldo Ferraz de. Bastos Tigre: eclética trajetória. Rio de Janeiro: Lado A Editores Associados, 1987.

- Almeida, Paulo Mendes de. Cartazes. São Paulo: Livraria Liberdade, 1928.

- As vidas de Bastos Tigre, 1882-1982. Rio de Janeiro: ABI: FUNARTE Centro de Documentação e Companhia de Cigarros Souza Cruz, 1982.

- BANDEIRA, Manuel. Estrela da vida inteira. São Paulo: Círculo do Livro, s.d.

- BILAC, Olavo. Vossa insolência: crônicas. São Paulo: Companhia das Letras.

- Edmundo, Luiz. O Rio de Janeiro do meu tempo. Rio de Janeiro: Imprensa Nacional, v. 3, 1938.

- Fernando, Jorge. Vida e poesia de Olavo Bilac. $4^{\underline{a}}$ ed. São Paulo: T.A. Queiroz, 1991.

- FinAtTo, Adelar. Álvaro Moreyra. 2ª ed. Porto Alegre: Tchê!, 1985. 
- Daudt Filho, João. Memórias de João Daudt Filho. $3^{\text {a }}$ ed. Rio de Janeiro: s.ed., 1949.

- Lessa, Orígenes. O feijão e o sonho. $15^{\underline{a}}$ ed. Rio de Janeiro: Edições de Ouro, s.d.

- Magalhães Jr., Raimundo. Poesia e vida de Casimiro de Abreu. $2^{\underline{a}}$ ed. São Paulo: Lisa; Rio de Janeiro: INL, 1972.

- Menezes, Raimundo. Martins Fontes. São Paulo: Edições Melhoramentos, s.d.

- Migliano, Mário Ferreira. Candido Fontoura: o homem e sua obra. São Paulo, s. ed., 1985.

- Pontes, Eloy. A vida exuberante de Olavo Bilac. Rio de Janeiro: Livraria José Olympio Editora, 2 v., 1944.

- SAliBA, Elias Thomé. Raízes do riso: a representação humorística na história brasileira: da Belle Époque aos primeiros tempos do rádio. São Paulo: Companhia das Letras, 2002.

- Tigre, Bastos. Instantâneos do Rio antigo. Campinas: Mercado de Letras: Cecult; São Paulo: Fapesp, 2003.

Inéditos

- JaCon, Maria Toniolo. Orígenes Lessa: a letra e o sonho. Assis: Faculdade de Ciências e Letras de Assis - Unesp, 1999. Dissertação de mestrado.

8. DEPOIMENTOS

- Conversa telefônica com Alexandre Wollner. São Paulo, 3 nov. 2004.

- Conversa telefônica com Vicente Augustus Carnicelli. São Paulo, 20 abr. 2001.

- Depoimento de Jean-Louis Fretin à autora. São Paulo, 24 maio de 2001.

- Depoimento de José Roberto Whitaker Penteado à autora. São Paulo, abr. 2002.

- Depoimento de Valério Pennacchi à autora. São Paulo, 2 jun. 2001. 
- http://brasilcult.pro.br/rio_antigo2/manuel_mora/bem_vindo.htm

- http://katia.cabaretvoltaire.com/blog/archives/2002_02.html

- http://www.dpto.com.br/historia/gerhard/entrev.htm

- http://www.vitruvius.com.br/arquitextos/arq058/arq058_00.asp

- www.bibvirt.futuro.usp.br

- www.dominiopublico.gov.br

- www.eliseuvisconti.com.br

- www.gibindex.com/enciclopedia/br/k/428

- www.homme-moderne.org/societe/socio/bourdieu/raisons/illusion.html

- www.ipct.pucrs.br/letras

- www.itaucultural.org.br

- www.jrwp.com.br/artigos/arquivo-artigos.asp?offset=120.

- www.lesartsdecoratifs.fr/fr/03museepublicite/index.html

- www.liceuescola.com.br

- www.ucad.fr 
- Instituto Moreira Salles

- Biblioteca do Instituto de Estudos Brasileiros da Universidade de São Paulo

- Biblioteca Napoleão de Carvalho da Escola Superior de Propaganda e Marketing

- Fundação de Patrimônio Histórico da Energia de São Paulo

- Biblioteca da Escola de Comunicações e Artes da Universidade de São Paulo

- Biblioteca Orígenes Lessa da Associação dos Profissionais de Propaganda

- Biblioteca e Centro de Documentação do Museu de Arte de São Paulo Assis Chateaubriand

FONTES PARA AS PESQUISAS ICONOGRÁFICAS

- Ariel: Revista de Cultura Musical, São Paulo, 1923-1924, 1926.

- base: revista de arte, técnica e pensamento, Rio de Janeiro, 1933.

- Bellas Artes: Órgão Official da Sociedade Brasileira de Bellas Artes, Rio de Janeiro, 1935-1940.

- Boa Nova: Revista Mensal Illustrada, Rio de Janeiro, 1933-1934.

- Careta, Rio de Janeiro, 1931, 1935-1936.

- Carioca, Rio de Janeiro, 1937-1938.

- A Cigarra, São Paulo, 1922-1924, 1926, 1930-1932.

- O Cruzeiro: Revista Semanal Illustrada, Rio de Janeiro, 1928-1938.

- Espelho, Rio de Janeiro, 1936-1937.

- Eu sei tudo, Rio de Janeiro, 1929-1937.

- Fon Fon: Revista Semanal Illustrada, Rio de Janeiro, 1928, 1930-1934.

- Illustração Brasileira, Rio de Janeiro, 1921, 1928-1930, 1935-1937.

- Kosmos, Rio de Janeiro, 1930.

- Light, Rio de Janeiro, 1930-1935.

- Medicina, Cirurgia, Farmácia/Laboratórios Silva Araújo-Roussel, Rio de Janeiro, 1934-1950.

- Mensagem: Quinzenário de Arte e Literatura, Belo Horizonte, 1939-1940.

- Novella: Quinzenal de Bôas Leituras, São Paulo, 1935, 1937. 
- O Observador: Econômico e Financeiro, Rio de Janeiro, 1936-1937.

- Papel e Tinta: Illustração Quinzenal Brazileira, S. Paulo e Rio, 1920-1921.

- Pernambuco, Recife, 1937-1938.

- Pan: Semanario de Leitura Mundial, Estados Unidos do Brasil, 1935-1936.

- Piralho, São Paulo, 1913.

- Programma Oficial do Teatro Municipal, São Paulo, 1935.

- Publicações Médicas, São Paulo, 1933, 1936, 1939-1940.

- Publicidade: Revista Técnica de Propaganda, Rio de Janeiro, 1940-1943.

- Publicidade: Revista de Propaganda e Negócios, Rio de Janeiro, 1944, 1946.

- Renovação: Órgão de Ação Educacional e Proletária, Recife, 1939-1940.

- A Revista, Belo Horizonte, 1925.

- Revista Acadêmica, Rio de Janeiro, 1933-1935.

- Revista do Globo, Porto Alegre, 1929-1943.

- Revista Industrial de S. Paulo, São Paulo, 1944-1945.

- Revista Nacional, São Paulo, 1921-1923.

- Revista Nacional de Educação: Museu Nacional, Rio de Janeiro, 1932-1934.

- Revista da Semana: Publicação de Arte, Literatura e Modas, Rio de Janeiro, 1929-1935.

- Ritmo, São Paulo, 1935.

- Rumo, Rio de Janeiro, 1933.

- Seiva: Syntese do Pensamento Brasileiro, São Paulo, 1935-1936.

- A Semana, Campinas, 1916.

- Silhueta, Campinas, 1916.

- Tentativa: Revista de Cultura, Belo Horizonte, 1939.

- Travel in Brazil, Rio de Janeiro, 1941-1942.

- Vamos Lêr, Rio de Janeiro, 1936.

- Verde: Revista Mensal de Arte e Cultura, Minas Gerais, 1927-1929.

- Vida Moderna, São Paulo, 1914, 1920.

- Weco: Revista de Vida e Cultura Musical, Rio de Janeiro, 1928-1930. 


\section{APÊNDICE}


As tabelas que se seguem foram elaboradas a partir dos títulos citados na Bibliografia. Em seus itens gerais, nosso critério priorizou o uso das biografias dos diversos profissionais estudados que constam de livros, catálogos, teses e em sites específicos, e na seqüência utilizamos o clássico dicionário de Carlos Cavalcanti, sem deixarmos de consultar outros mais recentes.

Quanto aos itens sobre as atividades publicitárias, foram eles obtidos ao longo de nossa pesquisa e, portanto nas mais diversas fontes, que também se encontram relacionadas dentre as referências bibliográficas e na relação de periódicos que constituíram o catálogo de imagens.

Nem todas as peças publicitárias citadas foram localizadas, mas incluimos as informações sobre suas possíveis existências por julgá-las pertinentes à construção do panorama que nós procuramos reconstituir. 
TABELA 1

Artistas Plásticos E Arquitetos

\begin{tabular}{|c|c|c|c|c|c|c|}
\hline ARTISTAS & $\begin{array}{l}\text { NASCIMENTO/ } \\
\text { MORTE }\end{array}$ & FORMAÇÃO & ATUAÇÃO & ATIVIDADES PROFISSIONAIS & ATIVIDADES PUBLICITÁRIAS & OBSERVAÇÕES \\
\hline $\begin{array}{l}\text { Alberto André Delpino } \\
\text { Junior } \\
\text { Del Pino }\end{array}$ & $\begin{array}{l}\text { 1904/07 - } 1985 \\
\text { MG - MG }\end{array}$ & Estudos com seu pai & MG/RJ & $\begin{array}{l}\text { Pintor, desenhista, ilustrador, } \\
\text { caricaturista }\end{array}$ & Sabonete Araxá & $\begin{array}{l}\text { Filho do pintor Alberto } \\
\text { André Feijó Delpino }\end{array}$ \\
\hline Alfredo Norfini & $\begin{array}{l}1867 \text { - } 1944 \\
\text { Florença, } \\
\text { Itália - RJ }\end{array}$ & $\begin{array}{l}\text { Real Academia de } \\
\text { Belas Artes de Lucca }\end{array}$ & $\mathrm{RJ} / \mathrm{SP}$ & $\begin{array}{l}\text { Pintor, desenhista, professor do } \\
\text { LAO/SP }\end{array}$ & Cia. Antártica Paulista & $\begin{array}{l}\text { Discípulo de Luiz Norfini. } \\
\text { Organizou a primeira } \\
\text { Exposição de Artes e Artes } \\
\text { Aplicadas às Indústrias } \\
\text { (1900) }\end{array}$ \\
\hline Antonio Paim Vieira & $\begin{array}{l}1895 \text { - } 1988 \\
\text { SP - SP }\end{array}$ & Escola Normal & SP & $\begin{array}{l}\text { Pintor, ilustrador, desenhista, } \\
\text { ceramista, professor }\end{array}$ & $\begin{array}{l}\text { Anúncios em Ariel para a } \\
\text { Casa de Modas Elisa Giaccone } \\
\text { Macelloni \& CA, Ramos } \\
\text { Alfaiataria, Lyra Paulistana, } \\
\text { Casa de Pianos Sotero, } \\
\text { pomada Onken, Zeitter e } \\
\text { Winkelmann, Galeria das } \\
\text { Sedas. Anúncios e ilustrações } \\
\text { para a empresa Rhodia }\end{array}$ & $\begin{array}{l}\text { Diretor artístico da revista } \\
\text { Pallas (SP, 1920-1921), } \\
\text { ilustrador da revista Ariel } \\
\text { (SP, 1922-1924) }\end{array}$ \\
\hline $\begin{array}{l}\text { Brunon Bronislaw } \\
\text { Lechowski } \\
\text { Bruno Lechowski }\end{array}$ & $\begin{array}{l}1887 \text { - } 1941 \\
\text { Varsóvia, } \\
\text { Polônia - RJ }\end{array}$ & $\begin{array}{l}\text { Academia de Belas } \\
\text { Artes, Kiev (1909), } \\
\text { Academia de São } \\
\text { Petersburgo, Rússia } \\
\text { (c. 1913). Núcleo } \\
\text { Bernardelli (1931- } \\
\text { 1935) }\end{array}$ & $\mathrm{RJ} / \mathrm{SP} / \mathrm{PR}$ & $\begin{array}{l}\text { Pintor, músico, arquiteto, } \\
\text { professor }\end{array}$ & $\begin{array}{l}\text { Trabalhou na Cia. dos } \\
\text { Anúncios em Bondes }{ }^{1}\end{array}$ & \\
\hline
\end{tabular}

${ }^{1}$ Informação não confirmada. Ver Alzira Alves de Abreu, “A alma do negócio”, Nossa História, Rio de Janeiro, (23): 38, set. 2005. 
TABELA 1 (CONTINUAÇÃo)

Artistas Plásticos E ARQUiTetos

\begin{tabular}{|c|c|c|c|c|c|c|}
\hline ARTISTAS & $\begin{array}{l}\text { NASCIMENTO/ } \\
\text { MORTE }\end{array}$ & FORMAÇÃO & ATUAÇÃO & ATIVIDADES PROFISSIONAIS & ATIVIDADES PUBLICITÁRIAS & OBSERVAÇÕES \\
\hline $\begin{array}{l}\text { Charlotta Adlerová } \\
\text { Carlota }\end{array}$ & $\begin{array}{l}1908 \text { - } 1989 \\
\text { Berlim, } \\
\text { Alemanha - SP }\end{array}$ & $\begin{array}{l}\text { Escola de Artes e } \\
\text { Ofícios de Berlin - } \\
\text { Charlottenburg, curso } \\
\text { de Desenho de Moda } \\
\text { em Reimann. Ateliês } \\
\text { de Waldemar da } \\
\text { Costa e de Samsor } \\
\text { Flexor }\end{array}$ & SP & $\begin{array}{l}\text { Pintora, gravadora, desenhista de } \\
\text { propaganda e de modas, arte } \\
\text { finalista, ilustradora, diretora de } \\
\text { arte }\end{array}$ & $\begin{array}{l}\text { Instituto Medicamenta } \\
\text { Fontoura e Serpe, free-lancer } \\
\text { de agências de publicidade } \\
\text { (1942), entre elas a Ayer. } \\
\text { Especialidade ilustrações de } \\
\text { figuras e caricaturas para } \\
\text { folhetos e anúncios. Criação de } \\
\text { embalagens }\end{array}$ & $\begin{array}{l}\text { Exposição CHARLOTTA } \\
\text { ENTRE A PUBLICIDADE E A } \\
\text { PINTURA (1983). Doação de } \\
\text { trabalhos publicitários ao } \\
\text { MASP }\end{array}$ \\
\hline Danilo Di Prete & $\begin{array}{l}1911 \text { - } 1985 \\
\text { Pisa, Itália - SP }\end{array}$ & Autodidata & SP & $\begin{array}{l}\text { Pintor, cartazista, programador } \\
\text { visual }\end{array}$ & $\begin{array}{l}\text { Standard Propaganda (1947), } \\
\text { Modas Clipper }\end{array}$ & $\begin{array}{l}\text { Venceu c. de } 23 \text { concursos } \\
\text { para cartazes (1946-1950). } \\
\text { Campanhas para o Hospital } \\
\text { das Clínicas, Jockey Club de } \\
\text { São Paulo, Diário de S. } \\
\text { Paulo. Cartaz para o I Salão } \\
\text { Nacional de Propaganda } \\
(1955)^{2}\end{array}$ \\
\hline $\begin{array}{l}\text { Emiliano A. C. de } \\
\text { Albuquerque Melo } \\
\text { Di Cavalcanti }\end{array}$ & $\begin{array}{l}1897-1976 \\
\text { RJ - RJ }\end{array}$ & $\begin{array}{l}\text { Direito (incompleto). } \\
\text { Academia Ranson, } \\
\text { Paris. Ateliê de } \\
\text { Georg Elpons }\end{array}$ & $\mathrm{RJ} / \mathrm{SP}$ & $\begin{array}{l}\text { Pintor, desenhista, caricaturista, } \\
\text { jornalista, escritor }\end{array}$ & Dentifrício Odol & $\begin{array}{l}\text { Diretor artístico da revista } \\
\text { Panoplia (SP, 1917-1919) }\end{array}$ \\
\hline
\end{tabular}

${ }^{2}$ O 1. ${ }^{0}$ Salão Nacional de Propaganda teria ocorrido em dezembro de 1950, no MASP. Quanto a essa divergência consultar o Capítulo I, p. 17 e nota 32. 
TABELA 1 (CONTINUAÇÃo)

Artistas Plásticos E ARquitetos

\begin{tabular}{|c|c|c|c|c|c|c|}
\hline ARTISTAS & $\begin{array}{l}\text { NASCIMENTO/ } \\
\text { MORTE }\end{array}$ & FORMAÇÃO & ATUAÇÃO & ATIVIDADES PROFISSIONAIS & ATIVIDADES PUBLICITÁRIAS & OBSERVAÇÕES \\
\hline Edgar Koetz & $\begin{array}{l}1914-1969 \\
\text { RS - RS }\end{array}$ & $\begin{array}{l}\text { Seção de Desenho da } \\
\text { Livraria do Globo }\end{array}$ & $\begin{array}{l}\text { RS/Buenos } \\
\text { Aires/SP }\end{array}$ & $\begin{array}{l}\text { Gravador, pintor, ilustrador, } \\
\text { letrista, cartazista, professor de } \\
\text { pintura na UFRGS }\end{array}$ & $\begin{array}{l}\text { Anúncios e cartazes } \\
\text { publicitários. Empresa de } \\
\text { Publicidade Caxiense (1940), } \\
\text { responsável pela parte técnica } \\
\text { de desenhos. Ministrou o curso } \\
\text { de Anatomia da Letra na } \\
\text { Escola de Propaganda do }_{\text {MAsP }^{3}}\end{array}$ & $\begin{array}{l}\text { Revista do Globo (Porto } \\
\text { Alegre, 1929-1945). } \\
\text { Venceu vários concursos } \\
\text { para cartazes, entre eles o do } \\
\text { Departamento Nacional de } \\
\text { Propaganda (1939). Criador } \\
\text { do abecedário do catálogo de } \\
\text { letras da Ed. Globo }\end{array}$ \\
\hline Eliseu D’Angelo Visconti & $\begin{array}{l}1866 \text { - } 1944 \\
\text { Salerno, } \\
\text { Itália - RJ }\end{array}$ & $\begin{array}{l}\text { LAO/RJ, AIBA. Em } \\
\text { Paris, Escola de } \\
\text { Belas Artes e Escola } \\
\text { Guérin (aluno de } \\
\text { Eugéne Grasset) }\end{array}$ & RJ & $\begin{array}{l}\text { Pintor, desenhista, ceramista, } \\
\text { decorador, professor }\end{array}$ & $\begin{array}{l}\text { Cartazes e rótulos para a Cia. } \\
\text { de Bebidas Antártica. Estudos } \\
\text { publicitários para a Casa } \\
\text { Bevilacqua e para embalagens } \\
\text { de charutos }\end{array}$ & $\begin{array}{l}\text { Responsável pela cadeira de } \\
\text { Composição Decorativa do } \\
\text { Curso de Arte Decorativa - } \\
\text { Extensão da Universidade do } \\
\text { Rio de Janeiro (1934-1943) }\end{array}$ \\
\hline Flávio de Carvalho & $\begin{array}{l}1899-1973 \\
\text { RJ - SP }\end{array}$ & $\begin{array}{l}\text { Engenheiro civil. } \\
\text { Estuda pintura na } \\
\text { King Edward the } \\
\text { Seventh School of } \\
\text { Fine Artes de New } \\
\text { Castle }\end{array}$ & SP & $\begin{array}{l}\text { Pintor, arquiteto, engenheiro civil, } \\
\text { decorador, escritor, cenógrafo, } \\
\text { teatrólogo }\end{array}$ & $\begin{array}{l}\text { Empreendimentos particulares, } \\
\text { ex.: cortinas metálicas de sua } \\
\text { própria fabricação, A Vaca - } \\
\text { fazenda Capuava, cartões de } \\
\text { divulgação de seu escritório }\end{array}$ & \\
\hline Fulvio Pennacchi & $\begin{array}{l}1905 \text { - } 1992 \\
\text { Pianacci, Villa } \\
\text { Collemandina, } \\
\text { Itália - SP }\end{array}$ & $\begin{array}{l}\text { Regio Istituto di Belli } \\
\text { Arti, Lucca }\end{array}$ & SP & Pintor, desenhista, ceramista & $\begin{array}{l}\text { Diversos estudos para cartazes } \\
\text { publicitários (1929-1932), } \\
\text { Cartaz publicitário para } \\
\text { Apogastrina (abr. 1932) }\end{array}$ & $\begin{array}{l}\text { Idealização de um ateliê de } \\
\text { propaganda, Creação Clamor } \\
\text { (1932), em sociedade com o } \\
\text { escultor Antelo Del Debbio }\end{array}$ \\
\hline
\end{tabular}

${ }^{3}$ Informação não confirmada, segundo Carla Fernanda Fontana, O ateliê de desenho da Livraria do Globo, São Paulo: Escola de Comunicações e Artes da Universidade de São Paulo, 2004, p. 160. TCC - Departamento de Jornalismo e Editoração. 
TABELA 1 (CONTINUAÇÃo)

Artistas Plásticos e Arquitetos

\begin{tabular}{|c|c|c|c|c|c|c|}
\hline ARTISTAS & $\begin{array}{l}\text { NASCIMENTO/ } \\
\text { MORTE }\end{array}$ & FORMAÇÃO & ATUAÇÃO & ATIVIDADES PROFISSIONAIS & ATIVIDADES PUBLICITÁRIAS & OBSERVAÇÕES \\
\hline João Fahrion & $\begin{array}{l}1898-1970 \\
\text { RS - RS }\end{array}$ & $\begin{array}{l}\text { Estudou desenho com } \\
\text { o escultor italiano } \\
\text { Giuseppe Gaudenzi, } \\
\text { na Escola Técnica } \\
\text { Parobé (Porto } \\
\text { Alegre). Viagem de } \\
\text { estudos para a } \\
\text { Europa (1920) }\end{array}$ & RS & $\begin{array}{l}\text { Ilustrador, gravador, pintor, poeta, } \\
\text { professor do Instituto de Artes de } \\
\text { Porto Alegre (1937-1970) }\end{array}$ & Não localizados & $\begin{array}{l}\text { Revista do Globo (Porto } \\
\text { Alegre, 1929- 1947) }\end{array}$ \\
\hline Hermelindo Fiaminghi & $\begin{array}{l}1920-2004 \\
\text { SP - SP }\end{array}$ & $\begin{array}{l}\text { LAO/SP (1936-1940), } \\
\text { ateliê de Waldemar } \\
\text { da Costa (1942) e de } \\
\text { Alfredo Volpi }\end{array}$ & SP & $\begin{array}{l}\text { Pintor, litógrafo, artista gráfico, } \\
\text { publicitário, professor }\end{array}$ & $\begin{array}{l}\text { Gráfica Lanzara (1944), } \\
\text { Graphstudio (1946-1948), } \\
\text { Diretor de arte da Lintas } \\
\text { International Advertising, } \\
\text { cartazes publicitários para a } \\
\text { Lever (1948-1952), } \\
\text { Sensação Modas (1952), } \\
\text { Primeira Agência Promocional } \\
\text { (1956-1959), free lance para } \\
\text { Panam (1959), Planejamento e } \\
\text { Divulgação e Propaganda } \\
\text { (1960) }\end{array}$ & $\begin{array}{l}\text { Companhia } \\
\text { Melhoramentos (1935), } \\
\text { Companhia Ipiranga } \\
\text { (1941-1944) } \\
\text { Cartaz da Escola de } \\
\text { Propaganda do MASP }{ }^{4}\end{array}$ \\
\hline Lívio Abramo & $\begin{array}{l}1903 \text { - } 1992 \\
\text { SP - Paraguai }\end{array}$ & $\begin{array}{l}\text { Desenho com Enrico } \\
\text { Vio.Ateliê de Stanley } \\
\text { William } \\
\text { Hayter(Paris) }\end{array}$ & $\begin{array}{l}\mathrm{SP} / \mathrm{RJ} / \\
\text { Paraguai }\end{array}$ & $\begin{array}{l}\text { Gravador, ilustrador, desenhista, } \\
\text { professor }\end{array}$ & $\begin{array}{l}\text { Desenhos de moda, cartazes de } \\
\text { propaganda, pinta anúncios, } \\
\text { cortinas de teatro e cinema } \\
\text { (1930, não localizados). } \\
\text { Desenhista-chefe da Empresa } \\
\text { Interamericana de Publicidade } \\
\text { (finais da déc. 40) }\end{array}$ & \\
\hline
\end{tabular}

${ }^{4}$ Trata-se da capa do Anteprojeto da Escola de Propaganda do MASP, que foi aproveitada como cartaz quando do lançamento da instituição. 
TABELA 1 (CONTINUAÇÃo)

ARTistas Plásticos E ARQUitetos

\begin{tabular}{|c|c|c|c|c|c|c|}
\hline ARTISTAS & $\begin{array}{l}\text { NASCIMENTO/ } \\
\text { MORTE }\end{array}$ & FORMAÇÃO & ATUAÇÃO & ATIVIDADES PROFISSIONAIS & ATIVIDADES PUBLICITÁRIAS & OBSERVAÇÕES \\
\hline $\begin{array}{l}\text { Maurice Nozières } \\
\text { M. Nozières }\end{array}$ & s.i. & Escola Boulle, Paris & RJ & Arquiteto & $\begin{array}{l}\text { Anúncio para a fábrica de } \\
\text { móveis Laubisch-Hirth e Casa } \\
\text { Leandro Martins }\end{array}$ & \\
\hline $\begin{array}{l}\text { Mick Carnicelli Sobrinho } \\
\text { Mick } \\
\text { Mik Carnicelli }\end{array}$ & $\begin{array}{l}1893 \text { - } 1967 \\
\text { Agropoli, } \\
\text { Itália - SP }\end{array}$ & $\begin{array}{l}\text { Pintura no Instituto } \\
\text { de Belas Artes de } \\
\text { Veneza }\end{array}$ & SP & Pintor, desenhista, ilustrador & $\begin{array}{l}\text { Cartazes e anúncios para a } \\
\text { Alfaiataria Carnicelli }\end{array}$ & $\begin{array}{l}\text { Diretor Artístico da revista } \\
\text { Papel e Tinta (SP, 1920- } \\
\text { 1921) }\end{array}$ \\
\hline Quirino Campofiorito & $\begin{array}{l}1902-1993 \\
\text { PA - RJ }\end{array}$ & $\begin{array}{l}\text { Pintura na ENBA/RJ. } \\
\text { Em Paris, ateliê de } \\
\text { Pongheon da } \\
\text { Academia Julian, } \\
\text { Academia Grande } \\
\text { Chaumière, curso } \\
\text { superior de Arte } \\
\text { Decorativa (1951) }\end{array}$ & RJ & $\begin{array}{l}\text { Pintor, desenhista, gravador, } \\
\text { caricaturista, ilustrador, professor, } \\
\text { crítico de arte }\end{array}$ & $\begin{array}{l}\text { Desenhista publicitário da } \\
\text { Metro Goldwyn-Mayer (1929- } \\
\text { 1930), anúncio do filme Ouro } \\
\text { (1929) }\end{array}$ & $\begin{array}{l}\text { Estudo para cartaz do Baile } \\
\text { do Teatro Municipal do Rio } \\
\text { de Janeiro (déc. 40). Dirige o } \\
\text { jornal Bellas-Artes (RJ, } \\
\text { 1935-1940) }\end{array}$ \\
\hline Thomaz Ianelli & $\begin{array}{l}1932-2001 \\
\text { SP - SP }\end{array}$ & $\begin{array}{l}\text { Desenho na } \\
\text { Associação Paulista } \\
\text { de Belas Artes }\end{array}$ & SP & $\begin{array}{l}\text { Pintor, ilustrador, desenhista, } \\
\text { gravador }\end{array}$ & $\begin{array}{l}\text { Cia. dos Anúncios em Bondes } \\
(1948-1955)\end{array}$ & \\
\hline
\end{tabular}


TABELA 1 (CONTINUAÇÃo)

Artistas Plásticos E ArQuitetos

\begin{tabular}{|c|c|c|c|c|c|c|}
\hline ARTISTAS & $\begin{array}{l}\text { NASCIMENTO/ } \\
\text { MORTE }\end{array}$ & FORMAÇÃO & ATUAÇÃO & ATIVIDADES PROFISSIONAIS & ATIVIDADES PUBLICITÁRIAS & OBSERVAÇÕES \\
\hline $\begin{array}{l}\text { Vicente do Rego } \\
\text { Monteiro }\end{array}$ & $\begin{array}{l}1899-1970 \\
\mathrm{PE}-\mathrm{PE}\end{array}$ & $\begin{array}{l}\text { ENBA/RJ. Academias } \\
\text { Colarossi, Julian e } \\
\text { Grande Chaumière, } \\
\text { Paris }\end{array}$ & $\begin{array}{l}\text { RJ/Recife/ } \\
\text { Paris }\end{array}$ & $\begin{array}{l}\text { Escultor, pintor, poeta, } \\
\text { desenhista, ilustrador, gravador }\end{array}$ & $\begin{array}{l}\text { Aguardente Gravatá, rótulo } \\
\text { para a Caninha Cristal, } \\
\text { Goiabada Peixe }\end{array}$ & \\
\hline Walter Levy & $\begin{array}{l}1905 \text { - } 1995 \\
\text { Oldesloe, } \\
\text { Alemanha - SP }\end{array}$ & $\begin{array}{l}\text { Escola de Artes e } \\
\text { Ofícios (1923-1927), } \\
\text { Dortmund. Grupo } \\
\text { Realismo Mágico e } \\
\text { membro da União } \\
\text { dos Pintores da } \\
\text { Vesfalia }\end{array}$ & $\begin{array}{l}\text { Alemanha/ } \\
\text { SP }\end{array}$ & $\begin{array}{l}\text { Pintor, desenhista publicitário, } \\
\text { ilustrador, gravador }\end{array}$ & $\begin{array}{l}\text { Desenhista publicitário da } \\
\text { Lintas (anos 30) }\end{array}$ & \\
\hline
\end{tabular}


TABELA 2

ARTISTAS GRÁFICOS: ILUSTRADORES E CARICATURISTAS

\begin{tabular}{|c|c|c|c|c|c|c|}
\hline ARTISTAS & $\begin{array}{l}\text { NASCIMENTO/ } \\
\text { MORTE }\end{array}$ & FORMAÇÃO & ATUAÇÃO & ATIVIDADES PROFISSIONAIS & ATIVIDADES PUBLICITÁRIAS & OBSERVAÇÕES \\
\hline $\begin{array}{l}\text { Afonso J.Lanza } \\
\text { Lanza, } L\end{array}$ & s.i. & $\begin{array}{l}\text { Estudos com Elpons } \\
\text { e Enrico Vio }\end{array}$ & SP & Pintor, desenhista & $\begin{array}{l}\text { Anúncios em Ariel, pomada } \\
\text { Onken, loção anticaspa, Casa de } \\
\text { Modas Elisa Giaccone Macelloni } \\
\text { \& CA, Casa Gagliano }\end{array}$ & \\
\hline Alberto Lima & s.i. & $\mathrm{LAO} / \mathrm{RJ}$ & $\mathrm{RJ}$ & Ilustrador, pintor, heraldista & Casa José Silva, Mestre e Blatgé & $\begin{array}{l}\text { Cartão-postal 1 } 1^{\text {a Semana }} \\
\text { Filatélica Juvenil RJ (1948) } \\
\text { Cartaz do Serviço Aéreo } \\
\text { Militar (1931) }\end{array}$ \\
\hline Alfredo Storni & $\begin{array}{l}1881-1966 \\
\text { RS - RJ }\end{array}$ & $\begin{array}{l}\text { Curso ginasial } \\
\text { (desenho) }\end{array}$ & $\mathrm{RJ}$ & Caricaturista & Goiabada da marca Peixe & \\
\hline $\begin{array}{l}\text { Álvaro Manuel Cotrim } \\
\text { Alvarus }\end{array}$ & $\begin{array}{l}1904-1985 \\
\text { RJ - RJ }\end{array}$ & Direito & $\mathrm{RJ}$ & $\begin{array}{l}\text { Caricaturista, chargista, } \\
\text { ilustrador, técnico de publicidade, } \\
\text { cenógrafo, pesquisador }\end{array}$ & $\begin{array}{l}\text { Light. Departamento de } \\
\text { publicidade da Caixa Econômica } \\
\text { Federal }\end{array}$ & Cartaz para teatro (1933) \\
\hline $\begin{array}{l}\text { Álvaro Marins } \\
\text { Seth }\end{array}$ & $\begin{array}{l}1891-1949 \\
\text { RJ - RJ }\end{array}$ & $\mathrm{LAO} / \mathrm{RJ}$ & RJ & $\begin{array}{l}\text { Caricaturista, ilustrador, } \\
\text { desenhista }\end{array}$ & $\begin{array}{l}\text { Anúncios para Casa Mathias, } \\
\text { Elixir de Inhame, Calçados Souto, } \\
\text { produtos Granado, Elixir } \\
\text { Galactogeno, pó de arroz Trian e } \\
\text { Orygam de Gally, loção } \\
\text { Phenomeno, cartão-postal para } \\
\text { Kraemina, Rex, Colarinho } \\
\text { Copacabana }\end{array}$ & $\begin{array}{l}\text { Atelier de Desenho Seth. } \\
\text { Capas da revista O Pharol da } \\
\text { Medicina (RJ) }\end{array}$ \\
\hline $\begin{array}{l}\text { Benedito Carneiro Bastos } \\
\text { Barreto } \\
\text { Belmonte }\end{array}$ & $\begin{array}{l}\text { 1896/97 - } 1947 \\
\text { SP - SP }\end{array}$ & $\begin{array}{l}\text { Medicina } \\
\text { (incompleto), } \\
\text { autodidata }\end{array}$ & SP & $\begin{array}{l}\text { Caricaturista, ilustrador, } \\
\text { desenhista, pintor, escritor, } \\
\text { jornalista, historiador }\end{array}$ & $\begin{array}{l}\text { Chefe do departamento de } \\
\text { Publicidade do escritório da } \\
\text { Metro Goldwyn-Mayer (SP, } \\
\text { 1926) }\end{array}$ & \\
\hline
\end{tabular}


TABELA 2 (CONTINUAÇÃo)

ARTISTAS GRÁFICOS: ILUSTRADORES ECARICATURISTAS

\begin{tabular}{|c|c|c|c|c|c|c|}
\hline ARTISTAS & $\begin{array}{l}\text { NASCIMENTO/ } \\
\text { MORTE }\end{array}$ & FORMAÇÃO & ATUAÇÃO & ATIVIDADES PROFISSIONAIS & ATIVIDADES PUBLICITÁRIAS & OBSERVAÇÕES \\
\hline $\begin{array}{l}\text { Calixto Cordeiro } \\
\text { K. Lixto } \\
\text { Oyrk, Sib, Bluff }\end{array}$ & $\begin{array}{l}1877-1957 \\
\text { RJ - SP }\end{array}$ & $\begin{array}{l}\text { Estudos com José } \\
\text { Vilas Boas e Artur } \\
\text { Lucas (gravura). } \\
\text { Casa da Moeda/RJ, } \\
\text { ENBA/RJ }\end{array}$ & RJ & $\begin{array}{l}\text { Caricaturista, professor de } \\
\text { desenho, litógrafo, ilustrador, } \\
\text { escritor de peças teatrais }\end{array}$ & $\begin{array}{l}\text { Anúncios da Loteria Federal, } \\
\text { cigarros York, fumos e cigarros } \\
\text { marca Veado, Bromil, Lugolina, } \\
\text { Saúde da Mulher, Bayer, } \\
\text { Sanagryppe, Light, Gaz, } \\
\text { conhaque Macieira, Dubonnet, } \\
\text { Parc Royal, biscoitos do Rio } \\
\text { Grande, cigarros Ophelia, água } \\
\text { mineral Salutaris, Caixa } \\
\text { Econômica Federal }\end{array}$ & $\begin{array}{l}\text { Cartaz para a Secretaria de } \\
\text { Saúde e Assistência }\end{array}$ \\
\hline $\begin{array}{l}\text { Carl Ernst Zeuner } \\
\text { E. Zeuner }\end{array}$ & $\begin{array}{l}1895 \text { - } 1967 \\
\text { Zwickau, } \\
\text { Alemanha - } \\
\text { RS }\end{array}$ & $\begin{array}{l}\text { Estudos em Leipzig } \\
\text { com Robert Hilping e } \\
\text { Walter Tiemann na } \\
\text { Academia de Artes } \\
\text { Gráficas }^{5}\end{array}$ & RS & $\begin{array}{l}\text { Artista gráfico, ilustrador, } \\
\text { litógrafo }\end{array}$ & $\begin{array}{l}\text { Cartazes para a Loteria do Estado } \\
\text { e anúncios publicitários para } \\
\text { Elixir Bi-Iodado Santo Expedito, } \\
\text { Varig, Fogões Geral }\end{array}$ & $\begin{array}{l}\text { Contratado pela Livraria do } \\
\text { Globo (1922-1966). Chefe da } \\
\text { Seção de Desenho da Editora } \\
\text { e Chefe de Arte da Clarim - } \\
\text { Empresa de Publicidade Ltda }\end{array}$ \\
\hline $\begin{array}{l}\text { Domingos Xavier de } \\
\text { Andrade } \\
\text { Monsã }\end{array}$ & $\begin{array}{l}1903-1940 \\
\text { MG - MG }\end{array}$ & $\begin{array}{l}\text { Arquitetura na } \\
\text { ENBA/RJ }\end{array}$ & MG & $\begin{array}{l}\text { Caricaturista, ilustrador, capista, } \\
\text { programador visual, artista } \\
\text { gráfico }\end{array}$ & $\begin{array}{l}\text { Loteria do Estado de Minas } \\
\text { Gerais }\end{array}$ & $\begin{array}{l}\text { Cartazes políticos para a } \\
\text { Saúde Pública, Indústria, } \\
\text { Comércio e Agricultura. } \\
\text { Fundador ao lado de Érico de } \\
\text { Paula, da primeira agência de } \\
\text { publicidade de BH. Cartão- } \\
\text { postal 1a Exposição Filatélica } \\
\text { Juvenil de Minas Gerais } \\
\text { (1939) }\end{array}$ \\
\hline $\begin{array}{l}\text { Fernando Correia Dias } \\
\text { de Araújo }\end{array}$ & $\begin{array}{l}\text { 1896/93 - } 1935 \\
\text { Pantoja, } \\
\text { Portugal - RJ }\end{array}$ & $\begin{array}{l}\text { Estudou artes } \\
\text { plásticas em Coimbra }\end{array}$ & SP/RJ & Ilustrador, caricaturista, ceramista & Bromil, Castro Leite & \\
\hline
\end{tabular}

${ }^{5}$ Informações não confirmadas. Idem, pp. 79-81. 
TABela 2 (ContinUaÇÃo)

ARTISTAS GRÁFICOS: ILUSTRADORES ECARICATURISTAS

\begin{tabular}{|c|c|c|c|c|c|c|}
\hline ARTISTAS & $\begin{array}{l}\text { NASCIMENTO/ } \\
\text { MORTE }\end{array}$ & FORMAÇÃO & ATUAÇÃO & ATIVIDADES PROFISSIONAIS & ATIVIDADES PUBLICITÁRIAS & OBSERVAÇÕES \\
\hline $\begin{array}{l}\text { Francisco Acquarone } \\
\text { Acqua }\end{array}$ & $\begin{array}{l}\text { 1896/98 - } 1954 \\
\text { RJ - RJ }\end{array}$ & ENBA/RJ & $\mathrm{RJ}$ & $\begin{array}{l}\text { Ilustrador, pintor, desenhista, } \\
\text { caricaturista, jornalista, professor, } \\
\text { historiador e crítico de arte }\end{array}$ & $\begin{array}{l}\text { Pasta e sabonete Nancy, } \\
\text { Indanthren, Kaol, Talcolin, A } \\
\text { Eqüitativa, Caixa Econômica, } \\
\text { Viação Excelsior }\end{array}$ & \\
\hline $\begin{array}{l}\text { Francisco Guimarães } \\
\text { Romano }\end{array}$ & $\begin{array}{l}1888-1953 \\
\text { RJ - RJ }\end{array}$ & s.i. & RJ & Caricaturista, desenhista & $\begin{array}{l}\text { Bromil, Societé Anonyme du } \\
\text { Gaz, Fiat }\end{array}$ & \\
\hline $\begin{array}{l}\text { João Paulo Lemmo } \\
\text { Lemmi } \\
\text { Voltolino }\end{array}$ & $\begin{array}{l}1884-1926 \\
\text { SP - SP }\end{array}$ & $\begin{array}{l}\text { Estudos de desenho } \\
\text { em Pisa, tipografia; } \\
\text { artes gráficas }\end{array}$ & SP & $\begin{array}{l}\text { Caricaturista, desenhista, } \\
\text { ilustrador, jornalista }\end{array}$ & $\begin{array}{l}\text { Lacta, Guaraná Espumante } \\
\text { Zanotta, cigarro Sudam Extra, } \\
\text { pianos Bechstein, logotipo da } \\
\text { Casa Fausto, Casa Michel }\end{array}$ & \\
\hline $\begin{array}{l}\text { Jean Gabriel Villin } \\
\text { J. G. Villin } \\
\text { J. G. V }\end{array}$ & $\begin{array}{l}1906 \text { - } 1979 \\
\text { Amiens, } \\
\text { França - SP }\end{array}$ & $\begin{array}{l}\text { Escola Bernard } \\
\text { Palissy, Paris }\end{array}$ & SP & $\begin{array}{l}\text { Ilustrador, desenhista publicitário, } \\
\text { pintor, professor de artes }\end{array}$ & $\begin{array}{l}\text { Metro-Goldwyn Mayer do } \\
\text { Brasil, Cimento Portland, } \\
\text { Indanthren. } \\
\text { Trabalhou na Cia. dos } \\
\text { Anúncios em Bondes e para as } \\
\text { agências N. W. Ayer, } \\
\text { Thompson e Panam }\end{array}$ & $\begin{array}{l}\text { Ilustrador das revistas } \\
\text { Arlequim (SP, 1927) e Boas } \\
\text { Estradas (SP, 1927-1928) }\end{array}$ \\
\hline
\end{tabular}


TABela 2 (ContinUaÇÃo)

ARTISTAS GRÁFICOS: ILUSTRADORES E CARICATURISTAS

\begin{tabular}{|c|c|c|c|c|c|c|}
\hline ARTISTAS & $\begin{array}{l}\text { NASCIMENTO/ } \\
\text { MORTE }\end{array}$ & FORMAÇÃO & ATUAÇÃO & ATIVIDADES PROFISSIONAIS & ATIVIDADES PUBLICITÁRIAS & OBSERVAÇÕES \\
\hline $\begin{array}{l}\text { José Carlos de Brito e } \\
\text { Cunha } \\
\text { J. Carlos, J. C }\end{array}$ & $\begin{array}{l}1884-1950 \\
\text { RJ - RJ }\end{array}$ & $\begin{array}{l}\text { Curso ginasial } \\
\text { (incompleto), } \\
\text { autodidata }\end{array}$ & RJ & $\begin{array}{l}\text { Caricaturista, desenhista, } \\
\text { ilustrador, publicitário, jornalista }\end{array}$ & $\begin{array}{l}\text { Bromil, Biotônico, Bayer, A } \\
\text { Saúde da Mulher, Melhoral, Pilol, } \\
\text { Brahma, Caixa Econômica } \\
\text { Federal, Mesbla, Light, conservas } \\
\text { Peixe, biscoitos Leal Santos, } \\
\text { Fábrica de Chocolates Moinho de } \\
\text { Ouro, tecidos e corantes } \\
\text { Indanthren, Gueldy, águas } \\
\text { Caxambú, Salutaris, águas } \\
\text { magnesiana e gazosa S. Lourenço, } \\
\text { licor Tajuja, Nestlé, cigarros } \\
\text { Belmont, Cinzano, Rádio } \\
\text { Ipanema, Discos Odeon, Cia. } \\
\text { Cinematográfica Cinédia, Casa } \\
\text { Baby, Casino Atlântico, Gaz. } \\
\text { Escritório publicitário (1931- } \\
\text { 1936) }\end{array}$ & \\
\hline Luís Sá & $\begin{array}{l}1907-1979 \\
\text { CE - RJ }\end{array}$ & s.i. & RJ & $\begin{array}{l}\text { Caricaturista, ilustrador, } \\
\text { cenógrafo de cinema e teatro, } \\
\text { programador visual }\end{array}$ & Cartão-postal Shell lubrificação & $\begin{array}{l}\text { Folheto BCG do Serviço } \\
\text { Nacional de Educação } \\
\text { Sanitária }\end{array}$ \\
\hline Manuel Móra & $\begin{array}{l}1884 \text { - } 1956 \\
\text { Portugal - RJ }\end{array}$ & s.i. & RJ & $\begin{array}{l}\text { Cartazista, capista, ilustrador, } \\
\text { pintor, figurinista }\end{array}$ & $\begin{array}{l}\text { Magazine Parc Royal, lança } \\
\text { perfume Alice, Quinado } \\
\text { Constantino, sabonetes Limol, } \\
\text { meias Mousseline, Água de } \\
\text { Junquilho }\end{array}$ & $\begin{array}{l}\text { Cartões-postaispara } \\
\text { oDepartamento de Turismo } \\
\text { da Municipalidade do Rio de } \\
\text { Janeiro. Colaborou com o } \\
\text { Departamento de Imprensa e } \\
\text { Propaganda (DIP, 1937) }\end{array}$ \\
\hline
\end{tabular}


TABELA 2 (CONTINUAÇÃo)

ARTISTAS GRÁFICOS: ILUSTRADORES E CARICATURISTAS

\begin{tabular}{|c|c|c|c|c|c|c|}
\hline ARTISTAS & $\begin{array}{l}\text { NASCIMENTO/ } \\
\text { MORTE }\end{array}$ & FORMAÇÃO & ATUAÇÃO & ATIVIDADES PROFISSIONAIS & ATIVIDADES PUBLICITÁRIAS & OBSERVAÇÕES \\
\hline $\begin{array}{l}\text { Nelson Carlos Boeira } \\
\text { Faedrich }\end{array}$ & $\begin{array}{l}1912 \text { - } 1994 \\
\text { RS - RS }\end{array}$ & $\begin{array}{l}\text { Autodidata e Seção } \\
\text { de Desenho da } \\
\text { Livraria do Globo }\end{array}$ & RS/RJ & $\begin{array}{l}\text { Ilustrador, cartazista, litógrafo, } \\
\text { cenógrafo, decorador, } \\
\text { diagramador, jornalista, gravador, } \\
\text { pintor }\end{array}$ & $\begin{array}{l}\text { Casa Victor, Varejo Bromberg, } \\
\text { Cerveja Continental, } \\
\text { Refrigerador Kelvinator, } \\
\text { cartazes litografados para a } \\
\text { Loteria Federal, logotipo das } \\
\text { Tintas Renner. Diretor do } \\
\text { Departamento de Arte da } \\
\text { Empresa Publicidade Prosper } \\
\text { (1939-1944) }\end{array}$ & $\begin{array}{l}\text { Sobrinho do pintor Oscar } \\
\text { Boeira, Revista do Globo } \\
\text { (Porto Alegre, 1932-1939; } \\
\text { 1944-1947) } \\
\text { Na déc. 40, várias vezes } \\
\text { premiado como cartazista. } \\
\text { Exposição de cartazes } \\
\text { publicitários dos anos } 30 \\
\text { (1995), doados ao Museu de } \\
\text { Comunicação Social de } \\
\text { Porto de Alegre }\end{array}$ \\
\hline $\begin{array}{l}\text { Orestes Acquarone } \\
\text { O. Acquarone, OAcq e O. } \\
\text { A. Salaberry }\end{array}$ & $\begin{array}{l}1875 \text { - } 1952 \\
\text { Montevidéu, } \\
\text { Uruguai - } \\
\text { Montevidéu, } \\
\text { Uruguai }\end{array}$ & $\begin{array}{l}\text { Desenho na Escola } \\
\text { Dante Alighieri, } \\
\text { Uruguai }\end{array}$ & $\begin{array}{l}\text { Montevidéu } \\
\text { /Buenos } \\
\text { Aires/RJ }\end{array}$ & $\begin{array}{l}\text { Desenhista, gravador, escultor, } \\
\text { artista gráfico }\end{array}$ & Bromil, Gaz & \\
\hline $\begin{array}{l}\text { Orestes Acquarone Filho } \\
\text { Orestes Acquarone } \\
\text { Acquarone Filho }\end{array}$ & $\begin{array}{l}1900 \text { - s.i. } \\
\text { Montevidéu, } \\
\text { Uruguai - s.i. }\end{array}$ & $\begin{array}{l}\text { ENBA de Buenos } \\
\text { Aires e do RJ }\end{array}$ & $\mathrm{RJ}$ & $\begin{array}{l}\text { Desenhista, escultor, pintor, } \\
\text { artista gráfico }\end{array}$ & $\begin{array}{l}\text { A partir de 1922, desenvolveu } \\
\text { trabalhos publicitários na empresa } \\
\text { Daudt Oliveira (xarope Bromil, A } \\
\text { Saúde da Mulher), anúncios da } \\
\text { Loteria Federal do Brasil, Nutrion }\end{array}$ & $\begin{array}{l}\text { Produziu cartazes } \\
\text { publicitários (não } \\
\text { localizados) }\end{array}$ \\
\hline
\end{tabular}

${ }^{6}$ Carla Fernanda Fontana menciona em seu estudo que estes cartazes não se encontram no referido museu. Segundo a autora os 20 cartazes expostos em 1995 “eram anúncios publicitários impressos a cores na antiga técnica de litografia pela Livraria do Globo de Porto Alegre”, entre os quais “cartazes da Loteria Estadual, da Cervejaria Continental, e da Liga de Defesa Nacional”. Idem, p. 197.

${ }^{7}$ As assinaturas que constam dos anúncios publicitários nem sempre conferem com os nomes usuais citados na literatura, portanto ficamos na dúvida se eles são de autoria de Orestes Acquarone ou do seu filho. 
TABela 2 (ContinUaÇÃo)

ARTISTAS GRÁFICOS: ILUSTRADORES E CARICATURISTAS

\begin{tabular}{|c|c|c|c|c|c|c|}
\hline ARTISTAS & $\begin{array}{l}\text { NASCIMENTO/ } \\
\text { MORTE }\end{array}$ & FORMAÇÃO & ATUAÇÃO & ATIVIDADES PROFISSIONAIS & ATIVIDADES PUBLICITÁRIAS & OBSERVAÇÕES \\
\hline $\begin{array}{l}\text { Sebastião de Camargo } \\
\text { Borges } \\
\text { Nino, Nino Borges }\end{array}$ & $\begin{array}{l}1897 \text { - s.i. } \\
\text { s.i. }\end{array}$ & $\begin{array}{l}\text { Estudos com } \\
\text { Benjamin } \\
\text { Constant Melo }\end{array}$ & $\mathrm{SP} / \mathrm{RJ}$ & Desenhista, caricaturista & $\begin{array}{l}\text { Antarctica, Editora Sociedade } \\
\text { Impressora Paulis, Reveillon, } \\
\text { Perpetualina, Edições Sociedade } \\
\text { Impressora Paulista }\end{array}$ & $\begin{array}{l}\text { Desenhista da Divisão de } \\
\text { Propaganda da General } \\
\text { Motors (c. 1926) }\end{array}$ \\
\hline Umberto Della Latta & $\begin{array}{l}1883-1961 \\
\text { Lucca, } \\
\text { Itália - SP }\end{array}$ & $\begin{array}{l}\text { Real Academia de } \\
\text { Belas Artes de Lucca }\end{array}$ & SP & Ilustrador, pintor & $\begin{array}{l}\text { Anúncios e cartazes para Loteria } \\
\text { do Estado de São Paulo, reclames } \\
\text { cosméticos Adoração, Chocolates } \\
\text { Falchi, caramelos Fruna, cigarros } \\
\text { Sudan, Castellões, Olga, 37, Luiz } \\
\text { XV e Commendadores }\end{array}$ & $\begin{array}{l}\text { Contratado pela Falchi e } \\
\text { Lacta. } \\
\text { Exposição de anúncios } \\
\text { comerciais (jan. 1917) }\end{array}$ \\
\hline
\end{tabular}


TABELA 3

PUBLICITÁRIOS E CARTAZISTAS

\begin{tabular}{|c|c|c|c|c|c|c|}
\hline ARTISTAS & $\begin{array}{l}\text { NASCIMENTO/ } \\
\text { MORTE }\end{array}$ & FORMAÇÃO & ATUAÇÃO & ATIVIDADES PROFISSIONAIS & ATIVIDADES PUBLICITÁRIAS & OBSERVAÇÕES \\
\hline $\begin{array}{l}\text { Américo Rosenberg } \\
\text { erico }\end{array}$ & s.i. & s.i. & s.i. & Desenhista publicitário & $\begin{array}{l}\text { Anúncios para os produtos do } \\
\text { Laboratório Silva Araújo. } \\
\text { Cartazes para Odol,Restaurant } \\
\text { Atalaia Hotel, Normandia } \\
\text { Laranjada,Cinzano, Vinovita, } \\
\text { Ytophan, firma Relâmpago, } \\
\text { General Eletric, Adalina, Rosvita } \\
\text { Depilatório, Lutz Ferrando, creme } \\
\text { Nívea, Guaraina }\end{array}$ & $\begin{array}{l}\text { Talvez tenha trabalhado com } \\
\text { o publicitário Armando } \\
\text { D’Almeida.Studio erico, } \\
\text { referências de } 1932 \text { a } 1946 . \\
\text { Cartão-postal 50 } 5^{0} \text { Congresso } \\
\text { da União Postal das } \\
\text { Américas e Espanha (1946) }\end{array}$ \\
\hline Ary Fagundes & $\begin{array}{l}1910 \text { - s.i. } \\
\text { RJ - s.i. }\end{array}$ & Arquitetura ENBA/RJ & RJ & Cartazista, desenhista & $\begin{array}{l}\text { Cartazes para Philips, Radio } \\
\text { Mullard, Great-Western }\end{array}$ & $\begin{array}{l}\text { Obras no Riverside Museum } \\
\text { de Nova York, artigo na } \\
\text { revista Gebrauchsgraphik } \\
\text { (mar. 1939). Cartazes para o } \\
\text { Museu de Belas Artes, Casa } \\
\text { dos Três Irmãos, Feira } \\
\text { Internacional de Amostras } \\
\text { do Rio de Janeiro (1935, } \\
\text { 1937), Semana da Economia } \\
\text { (1936),Teatro Municipal } \\
\text { (1939, 1941), Cassino } \\
\text { Atlântico (1939), I } \\
\text { Congresso Brasileiro de } \\
\text { Urbanismo (1940), } \\
\text { Propaganda do Japão (1940), } \\
\text { Semana da Asa (1940), } \\
\text { Temporada Internacional do } \\
\text { Ciclismo }\end{array}$ \\
\hline Franz Kohout & s.i. & s.i. & s.i. & s.i. & $\begin{array}{l}\text { Cartaz e reclame para } \\
\text { Instantina da Bayer, Odol, A } \\
\text { Saúde da Mulher, Bromil, } \\
\text { Aristolino, sabonetes Olivan, } \\
\text { Aymoré, Indanthren, Stacomb }\end{array}$ & \\
\hline
\end{tabular}


TABela 3 (CONTINUaÇão)

PUBLICITÁRIOS E CARTAZISTAS

\begin{tabular}{|c|c|c|c|c|c|c|}
\hline ARTISTAS & $\begin{array}{l}\text { NASCIMENTO/ } \\
\text { MORTE }\end{array}$ & FORMAÇÃO & ATUAÇÃO & ATIVIDADES PROFISSIONAIS & ATIVIDADES PUBLICITÁRIAS & OBSERVAÇÕES \\
\hline Gerhard Orthof & $\begin{array}{l}1903 \text { - } 1993 \\
\text { Viena, Aústria - } \\
\text { RJ }\end{array}$ & $\begin{array}{l}\text { Em Viena, estuda } \\
\text { com o pintor } \\
\text { Windhager, freqüenta } \\
\text { a Escola de Artes } \\
\text { Gráficas e a } \\
\text { Academia de Belas } \\
\text { Artes. Em Berlim, } \\
\text { estuda com os } \\
\text { professores } \\
\text { Ferdinand Spiegel e } \\
\text { Karth Hofer. }\end{array}$ & SP/RJ & $\begin{array}{l}\text { Pintor, cartazista, desenhista, } \\
\text { paginador }\end{array}$ & $\begin{array}{l}\text { Fundou Orthof Ltda. (1933), } \\
\text { Empresa de Propaganda Época S. } \\
\text { A. (1937). Trabalhou na Cia. dos } \\
\text { Anúncios em Bondes. } \\
\text { Urodonal (Época). } \\
\text { Cartazes de propaganda para A } \\
\text { esquina da Sorte, Orygam de } \\
\text { Gally, Casa David, Aymoré }\end{array}$ & $\begin{array}{l}\text { Paginador artístico da revista } \\
\text { O Cruzeiro (RJ, 1928). } \\
\text { Seus cartazes se perderam } \\
\text { em dois incêndios }\end{array}$ \\
\hline Gerhard Wilda & $\begin{array}{l}1915 \\
\text { Hamburgo, } \\
\text { Alemanha - }\end{array}$ & $\begin{array}{l}\text { Estágio Rudolf } \\
\text { Mosse. British- } \\
\text { Continental Press } \\
\text { Ltd. }\end{array}$ & $\begin{array}{l}\text { Alemanha/ } \\
\text { Inglaterra/ } \\
\text { Brasil }\end{array}$ & Diretor de arte, artista gráfico & $\begin{array}{l}\text { N. W. Ayer\& Son (c. 1936), } \\
\text { McCann-Erickson (1945), } \\
\text { Lintas (1952-1965), P. A. } \\
\text { Nascimento-Acar, Designo- } \\
\text { plus (1971). Logotipo da } \\
\text { Kibon }\end{array}$ & Membro fundador da EsPM \\
\hline $\begin{array}{l}\text { Geza von Puttkamer } \\
\text { Barão Puttkamer }\end{array}$ & $\begin{array}{l}\text { s.i. - déc. } 1960 \\
\text { Alemanha - } \\
\text { Alemanha }\end{array}$ & s.i. & RJ & $\begin{array}{l}\text { Capista, cartazista, desenhista } \\
\text { publicitário }\end{array}$ & $\begin{array}{l}\text { Trabalhou na Cia. dos Anúncios } \\
\text { em Bondes. Anúncios para a } \\
\text { Pasta Oriental, Bromil,casa de } \\
\text { móveis Otto Schuette Filho }\end{array}$ & $\begin{array}{l}\text { Capista da Revista da } \\
\text { Semana }\end{array}$ \\
\hline $\begin{array}{l}\text { Henrique Mirgalowsky } \\
\text { Mirga }\end{array}$ & $\begin{array}{l}1900 \text { - } 1966 \\
\text { Polônia - SP }\end{array}$ & s.i. & $\mathrm{RJ} / \mathrm{SP}$ & Cartazista & $\begin{array}{l}\text { Cia. dos Anúncios em Bondes. } \\
\text { Anúncios para Paraventi, Assucar } \\
\text { Leblon, Óleo Vida, Café da } \\
\text { Metrópole, A Saúde da Mulher, } \\
\text { Atelier Viennense Mme. Mariella, } \\
\text { Casas Pernambucanas }\end{array}$ & \\
\hline
\end{tabular}


TABela 3 (CONTINUaÇão)

PUBLICITÁRIOS E CARTAZISTAS

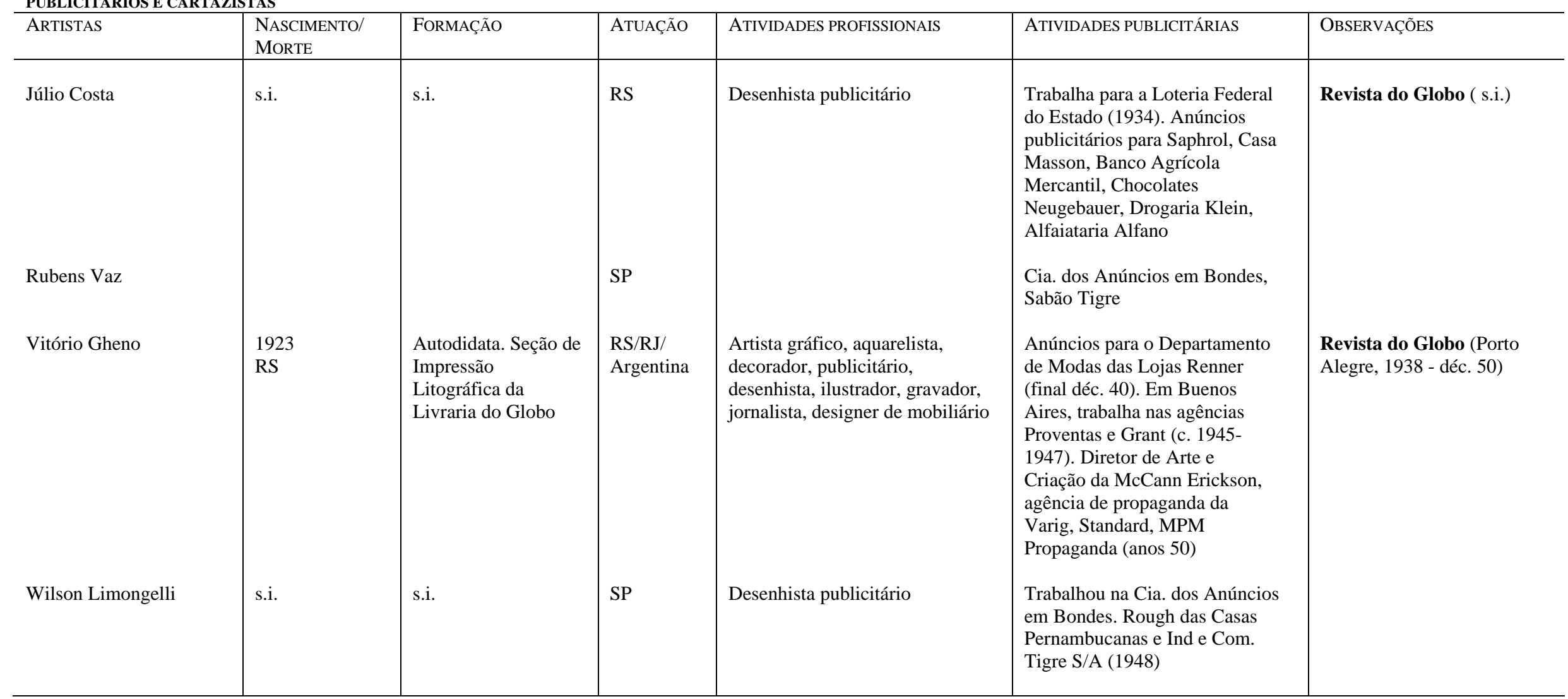


ANEXOS 
O anexo “Arte - Final” (pp. 21-25), integra o Anteprojeto da Escola de Propaganda do Museu de Arte de São Paulo. Documento datilografado localizado na Biblioteca e Centro de Documentação do Museu de Arte de São Paulo Assis Chateaubriand.

O publicitário Rodolfo Lima Martensen em suas memórias menciona que constava do Anteprojeto da Escola de Propaganda do Museu de Arte de São Paulo dez matérias básicas: Elementos de Propaganda, Técnica de Esboço (layout), Arte Final, Produção e Artes Gráficas, Redação, Rádio-Cine-TV, Mídia, Pesquisa e Estatística, Promoção de Vendas e Psicologia. Este documento foi entregue a Pietro Maria Bardi e posteriormente ao próprio Assis Chateaubriand, em outubro de $1951{ }^{1}$

Observamos que na página 21, item 3-d, a parte ilegível corresponde a Cartazes.

${ }^{1}$ Rodolfo Lima Martensen, Desafio de quatro santos: memórias, São Paulo: LR Editores, 1983, pp. 282-283. 


\section{Arte - Final}

I. Introdução e descrição do Programa

II. Definição da natória:

1. Significado da expressão Arte Final

a. Interpretação gráfica de uma idéia, croquis, layout, para fins de reprodução, projeção.

2. $O$ que compreende a A.P.? (sue relação com $\circ$ layout)

a. I?.uetraçäo principal

b. Sketcies (desenhos auxiliares)

c. Embalagons

d. Letreiros

e. Marcas

3. Visualização:

Capacidade de um artista de enxergar mentalmente a obra a ser executada, antes de pegar no instrumento de desenho ou pintura (cinema cerebral).

4. O Layout dentro de uma A.P.:

Direção visual da composição da A.F. para guiar.o slho do observador ao ponto importante da mensagem, ou seja, uma frase, $\circ$ produto, ○ slogan, $\circ$ noem, etc.

III. Funções e objetivos da A.F.:

1. As diversas funções da A.F.:

a, causar uma sensação de emoção

b. Informar sobre um assunto ou produto

c. difundir una expressão artística

d. propagar uma idéia

2. Considerações básicas:-

Diversas modalidades da Arte:

a. -Arte Popular (dirigida às massas e classes de um nivel cultural inferior)

b. Arte Bducativa

c. Arte con cunho técnico

d. Arte "sofisticada"

e. Arte informativa

f. Arte humoristica

g. Arte pura (arte de salão)

3. As múltiplas aplicações de una A.P. en:

a. Anúncios

b. Polnetos

c. Catálogos

a namtann 


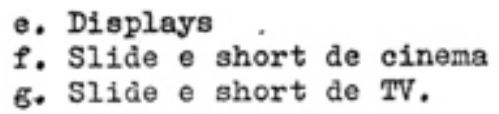

4. Instintos Básicos a serem explorados com uma arte:
a. Maternal
b. Sexual
c. Preservação proppria
d. Proteção
e. Desejo do fugir
f. Medo
g. Medo de cair doente
h. Desejo de ter coisas
i. Desejo de atrair
j. hnor pelo elogio
k. Descjo de se destacar e causar atenção
1. Desejo de dominar, ser superior
m. Desejo de prosperar

5. Fator IENPO na obsorvação de una mensagem publicitária:

Quanto tempo, en nédic, uma 1lustração é reparada?

- em jornais

- em revistas

- en cartazes (cartazes de estradas,nédia de 10 sesundas).

A A.F. tem que ser planejada de acôrdo e não pode desperdiçar oon detalhes não funcionais (con exceções).

IV. Arte Pinal en função do produto e da Média:

1. Considerações básicas na enconenda đe um A.F.:

a. Estilo a ser adotado em relação ao produto ou assunto e ao público a ser beneficiado

b. Técnica da A.F. con relação ao velculo de propaganda que carregará a publicidade

c. Psj.cologia con relação à classe de público a ser visada

2. Corres:

a. Patos injortantes na sua correta aplicação

b. Patores emotivos (vermelho: excitante; verde, azul, lilás, rouxo, cinza: calmante (lembrar o verde da natureza).

c. Creador de sensações (moods)

d. Cores quentes ou frias (Azuladios para refrigerantes e exonplos similares)

3. Análise de Eôsto e preferência:

a: Investigação entre o povo sobre a preferência de. una ou de outra arte a ser aplicada em uma mensagem. 
4. Pesquisa popular sobre Arte Final:

a. Método racional para deterninar o tipo mais indicado de Arte Final en relação ao público a que se deg tina a propaganda (1igar o/Pesquisas de Mercado).

V. Orientação da Execução da A.P.:

1. Quem orienta a A.P.?

a. Resumo das funções de un Dirotor de Arte dentro do quađ̊ro de uma Agência de Propaganda ou ingtituição ou organização que empregue un tal.

2. Quen executa una A.P.?

a. Näo são necessàrianente sempre elementos com experiência no ramo publicitário ou que tenham nftido conhecinento dos problemas de reprodução ou projeção. O dirotor de arte sempre dú a orientação técnica en cada caso (arte de salão já encontra aplicação no ramo publicitário).

b. Resumo das habilidades e conhecimentos de um artista de publicidade versado.

c. Artistas contratados e "freelance".

d. Custas.

e. Valor da Arte em relação ao espaço

3. Interpretação:

a. O artista deve ou não deve soguir ceganente o esbo§๐, ou pode interpretá-lo?

4. Arquivo de recortes e fotografia:

a. Auxiliares na execução de una A.P.

5. Valor cinza:

a. Ređução de todos os valores (inclusive côres) ao fator cinza, para deterninar a fôrça de uná A.P.

6. Porça da A.F.:

a. O equilibrio da A.F. em relação aos demais elementos da mensagem

VI. Técnicas e Est1los:

1. Estilo:

Explicação das diversas tendencias artfsticas, como:

a. desenho fotográfico

b. desenho sketchy

c. desenho estilizado (reduzido às suas linhas vitais (outline-contorno, caracterfsticas)

d. desenho sketchy com cunho fotográfico (ilustraçőes dos contos nas revistas americanas)

2. Tónicas aplicadas en A.F. comercial:Resumo sem entrar em detalhes tócnicos: 
a. Deaenho a traço:

Pincel, pincel sêco,pena, (exenplos práticos) aplicação de Ben-Day (explicar), retfcula (explicar)

b. Vantagens e desvantagens desta tઈ́cnica: Explicação dos problemas de reprodus̆o,visibilidade, contraste, aplicação.

c. Desenhos à aquarela - Têrpera (desenhos aguados): Mostrar através de exeiplos projotados e práticos.

d. Vantagem desta técnica: (vide ponto 16)

e. Desenhos (pintura) a Sleo: (vide ponto 15)

f. Vantagens desta técnica: (vide ponto 16)

g. Desenhos à pastel, lápis, crayon, gis: (vide ptọ.15)

h. Vantagens desta técnica: (vide ponto 16)

1. Técnicas especiais:

- Scratch (ou scraper) board

- Papel con efeitos de retfculas de diversas naturezas

- Papel com superficie granulada (diversos efeitos) produzidos com un lápis litográfico (nole, oleosо - Rossboard)

- Papéis celofane cor diversos efeitos (reticula e Ben-Days) a ser deitado por cina de un desenho

- Aerbgrafo

5. Potografia:

A sua aplicação.Ela substituta do desenho, ou v.v.?

k. Fotografia en preto - branco:

Aplicações: - table-top (natureza morta)

- pessoas

- indústrias e reportagens

1. Fotografias en preto - branco: Aplicações en relação aos vef́culos indicados

m. Fotografia em cores: (vide ponto 24)

n. Fotografia em corres: Aplicação (vide ponto 26)

o. Fotografia en geral (técnica):

- Iluminação

- Modelos

- Maquillage

- Truques

- Montagen

3. FenÔmenos das côres:

- Ilusões da retícula

- Quadricromia

- Efeito do papel branco como agente olareador (tem - mesmo papel como a tinta branca na mistura das tintas, porém, reage diferentenente). 
VII. Lettering (letras em estudo sui-generis):

1. As famflias de tipos (dados historicos)

2. A psicologia de uma "família" de tipos

3. Handlettering

VIII. Arte-Final em relação às várias culturas:

1. Psicologia dos diversos povos

2. Exemplos dos diversos países

3. Aulas individuais sobre cada povo com forte produção de naterial propagandístico e pronunciada personalidade.

4. Curiosidades históricas com referência à arte comercial: Resumo das tendîncias aŕtlsticas no fim do século passado e coneço deste.

IX. Exame en aula de peças notáveis de A.F. 


\section{Diálogo entre as Artes Plásticas e a Publicidade no Brasil}

Tese apresentada à Área de Concentração: Artes Plásticas da Escola de Comunicações e Artes da Universidade de São Paulo, como exigência parcial para obtenção do Título de Doutor em Artes, sob a orientação da Prof ${ }^{a}$ Dr $^{\mathrm{a}}$ Annateresa Fabris.

São Paulo 
CATÁlogo de i magens 

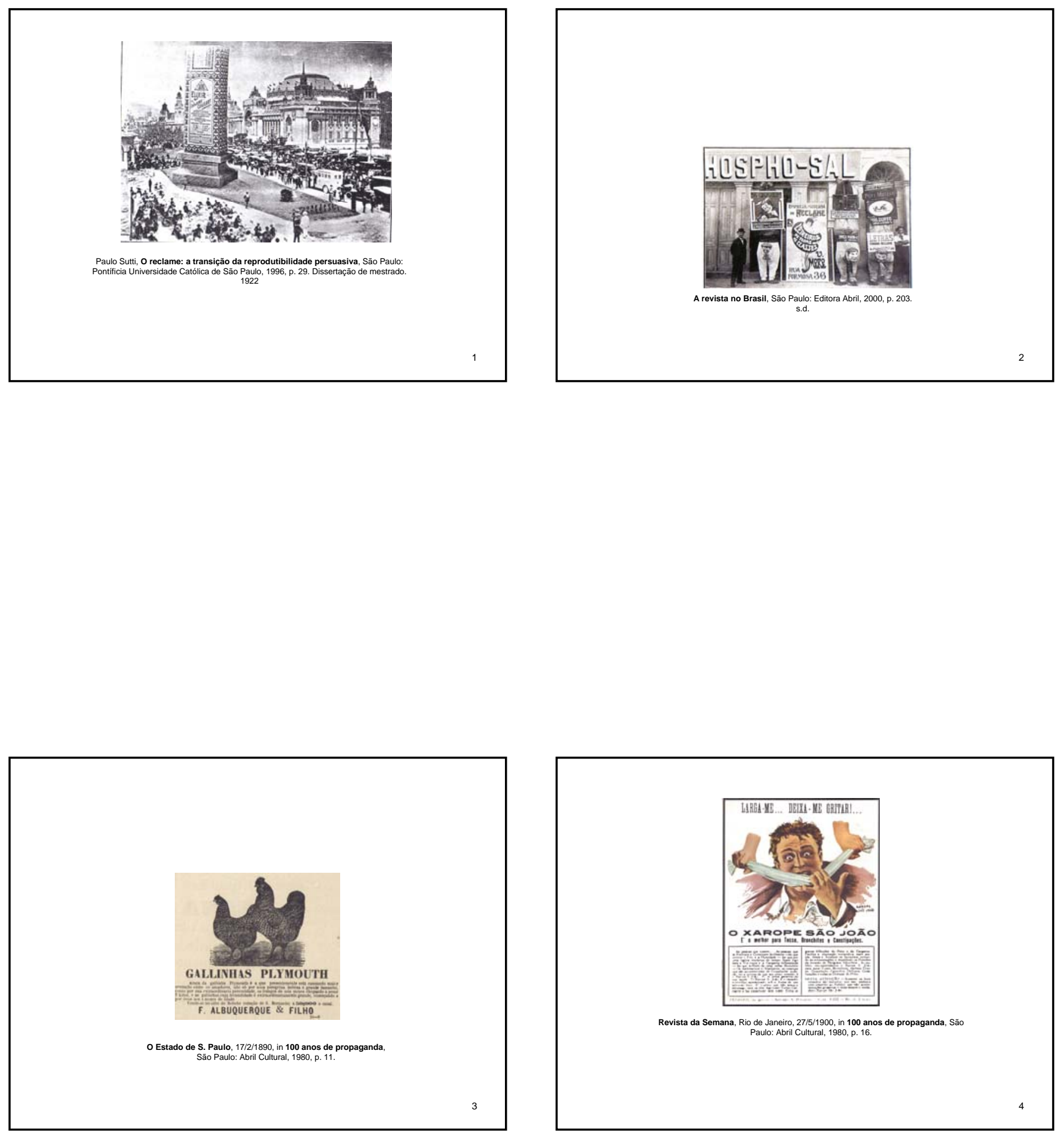

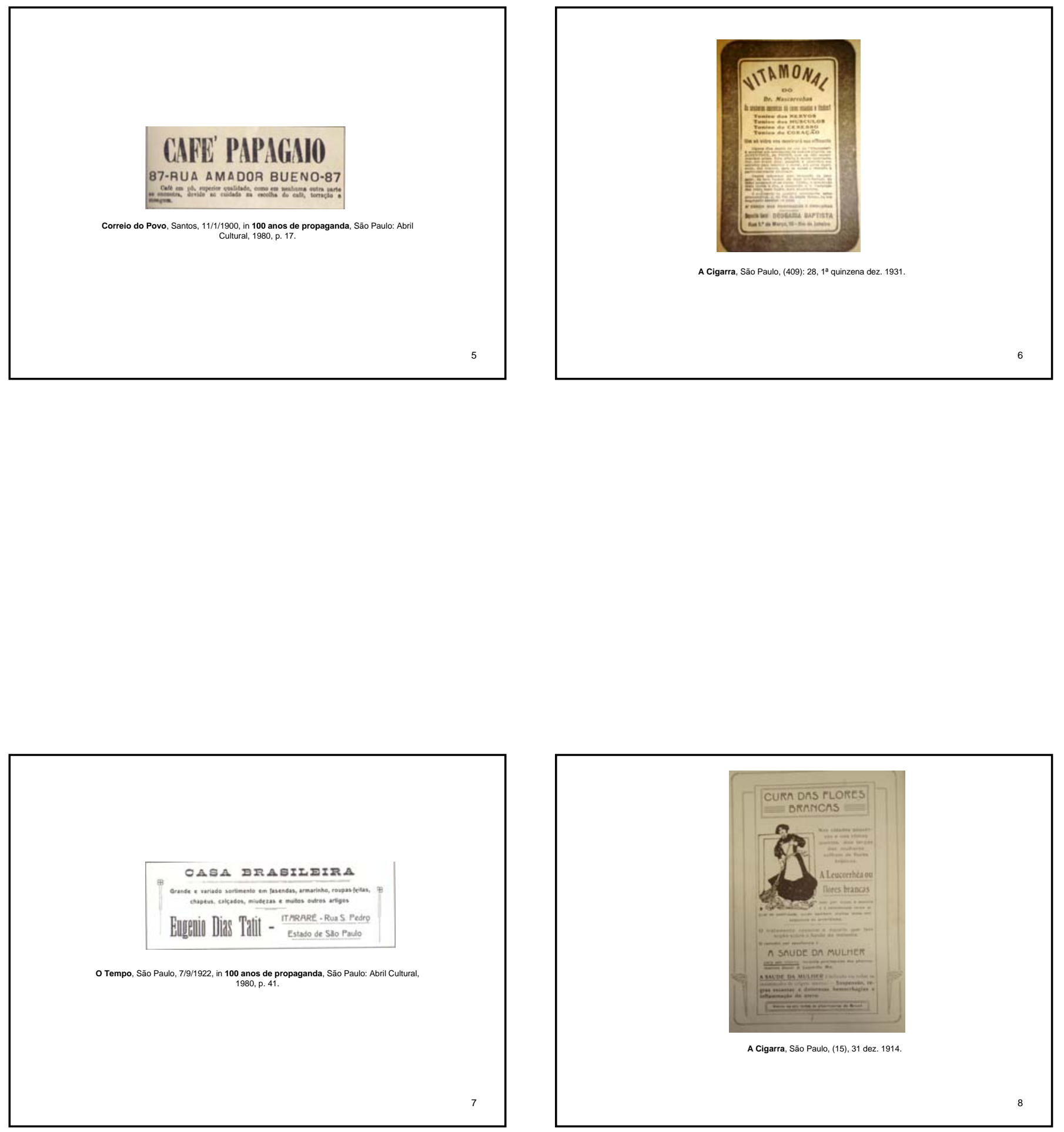

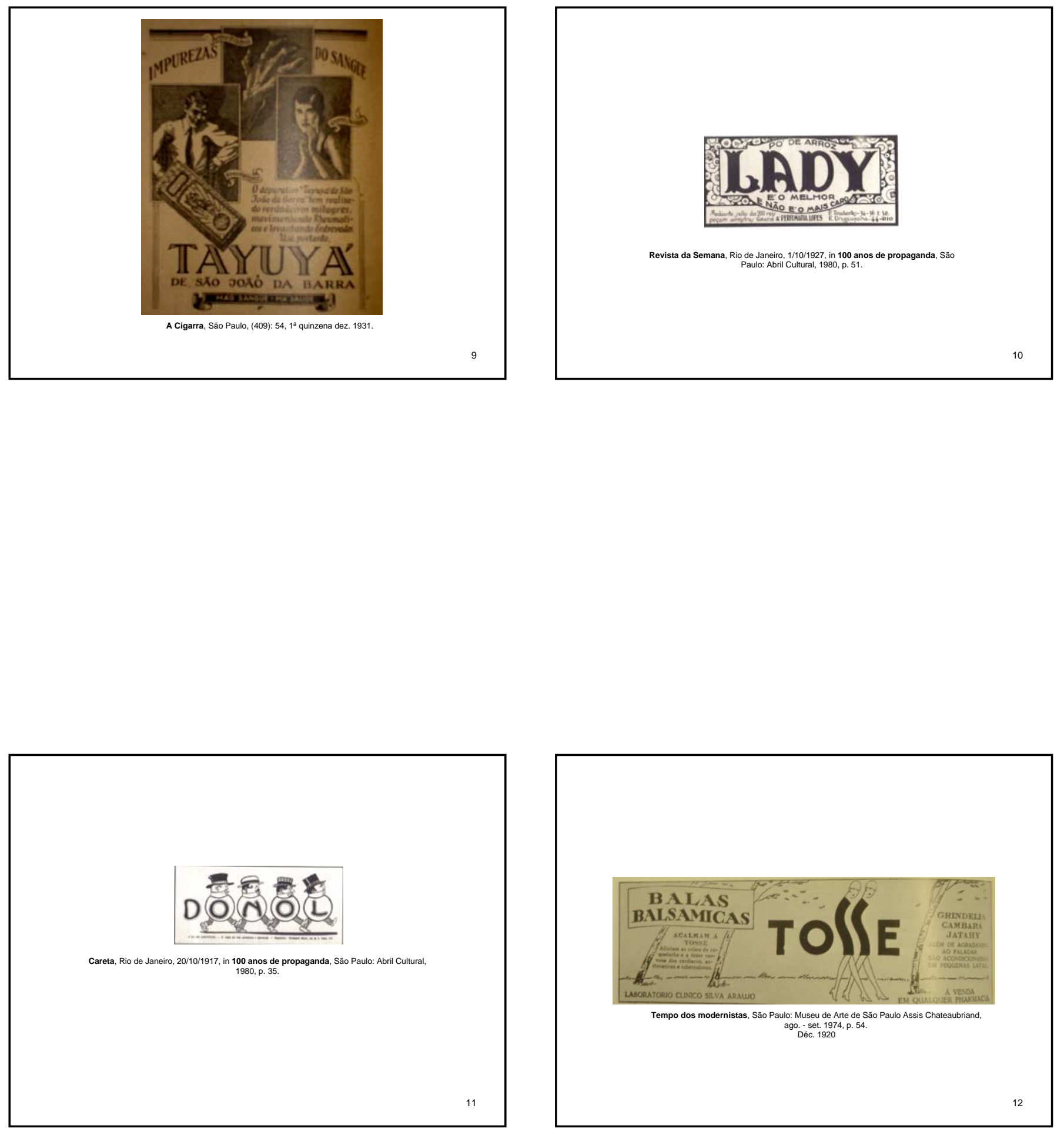

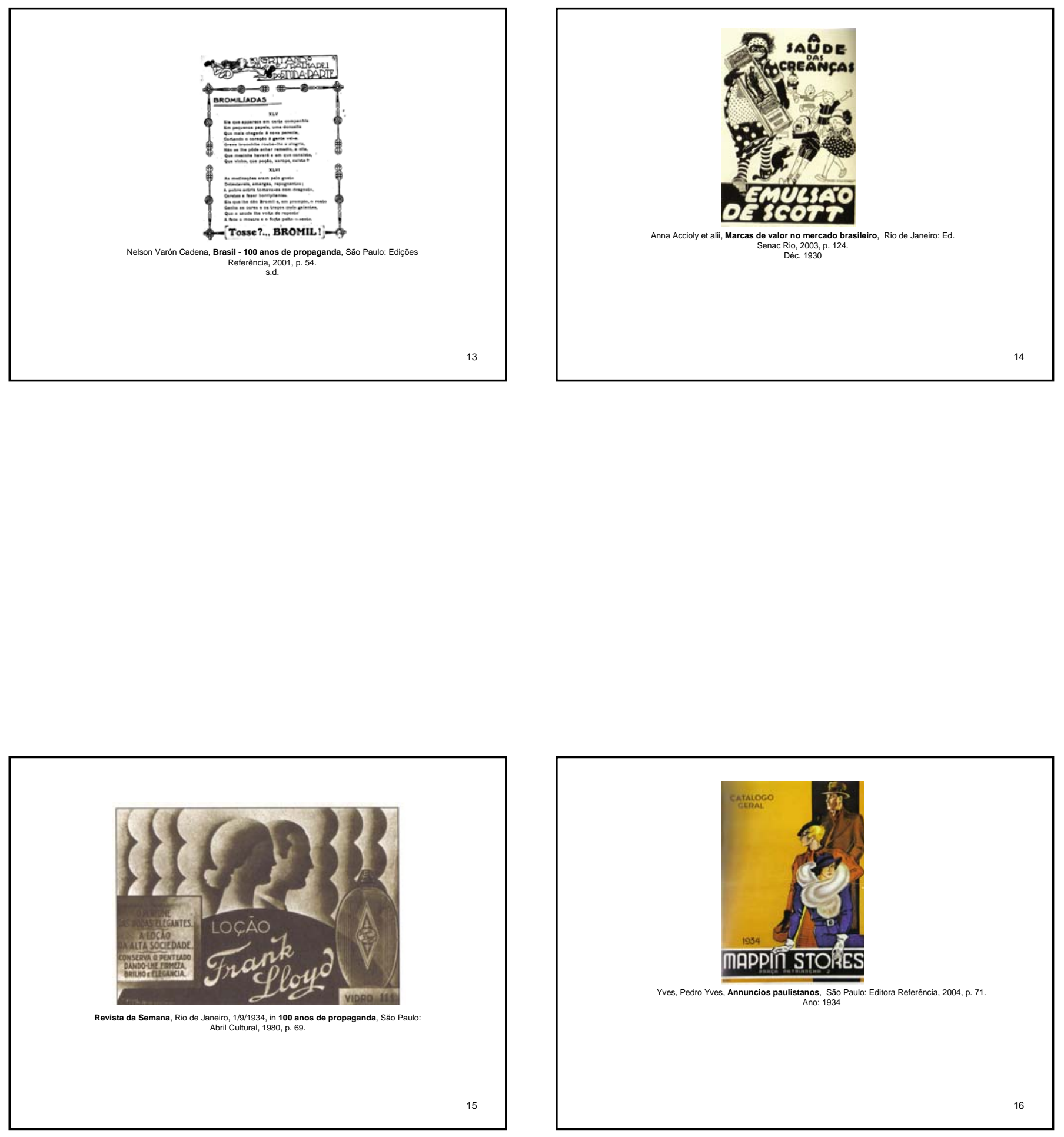

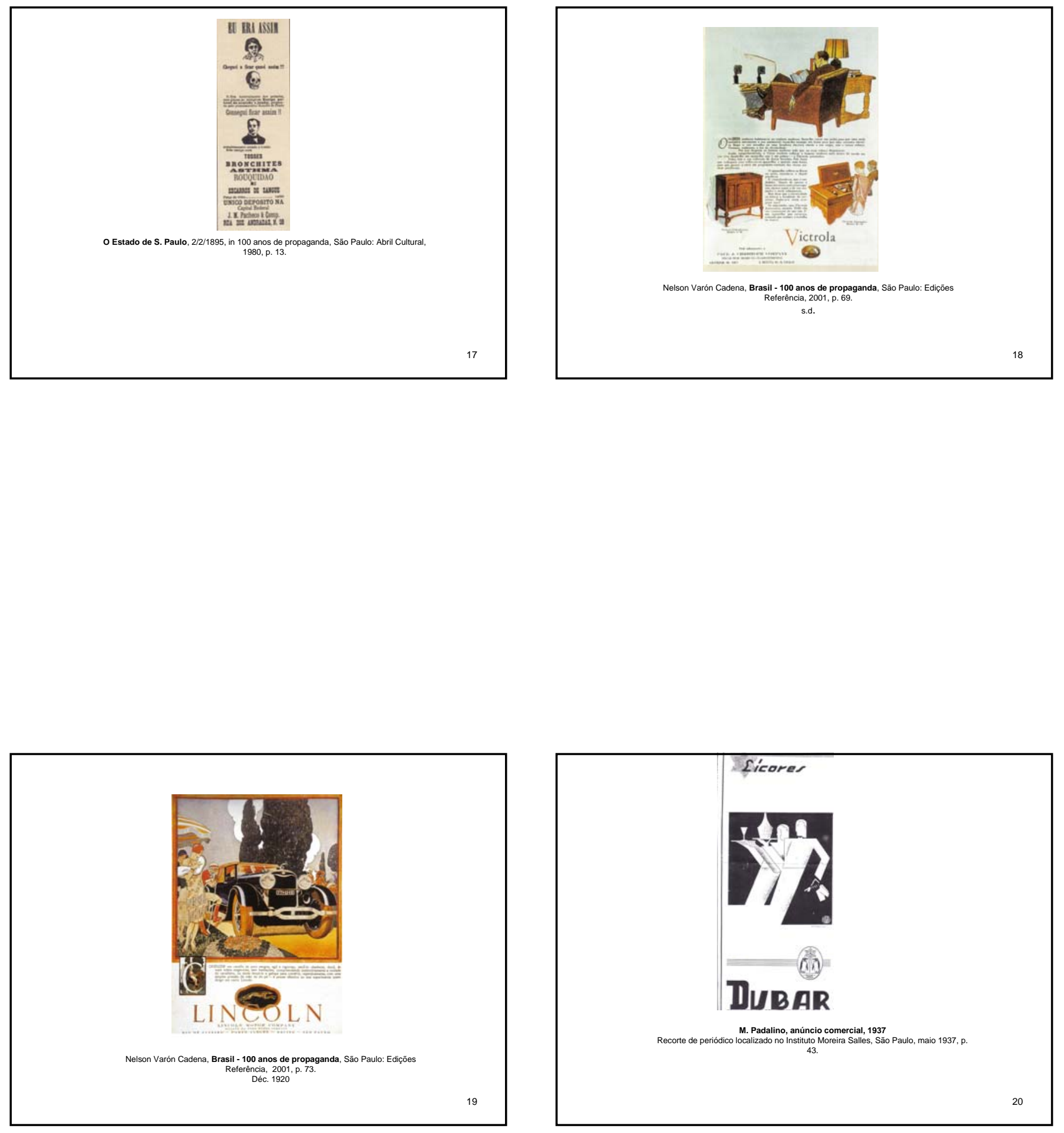

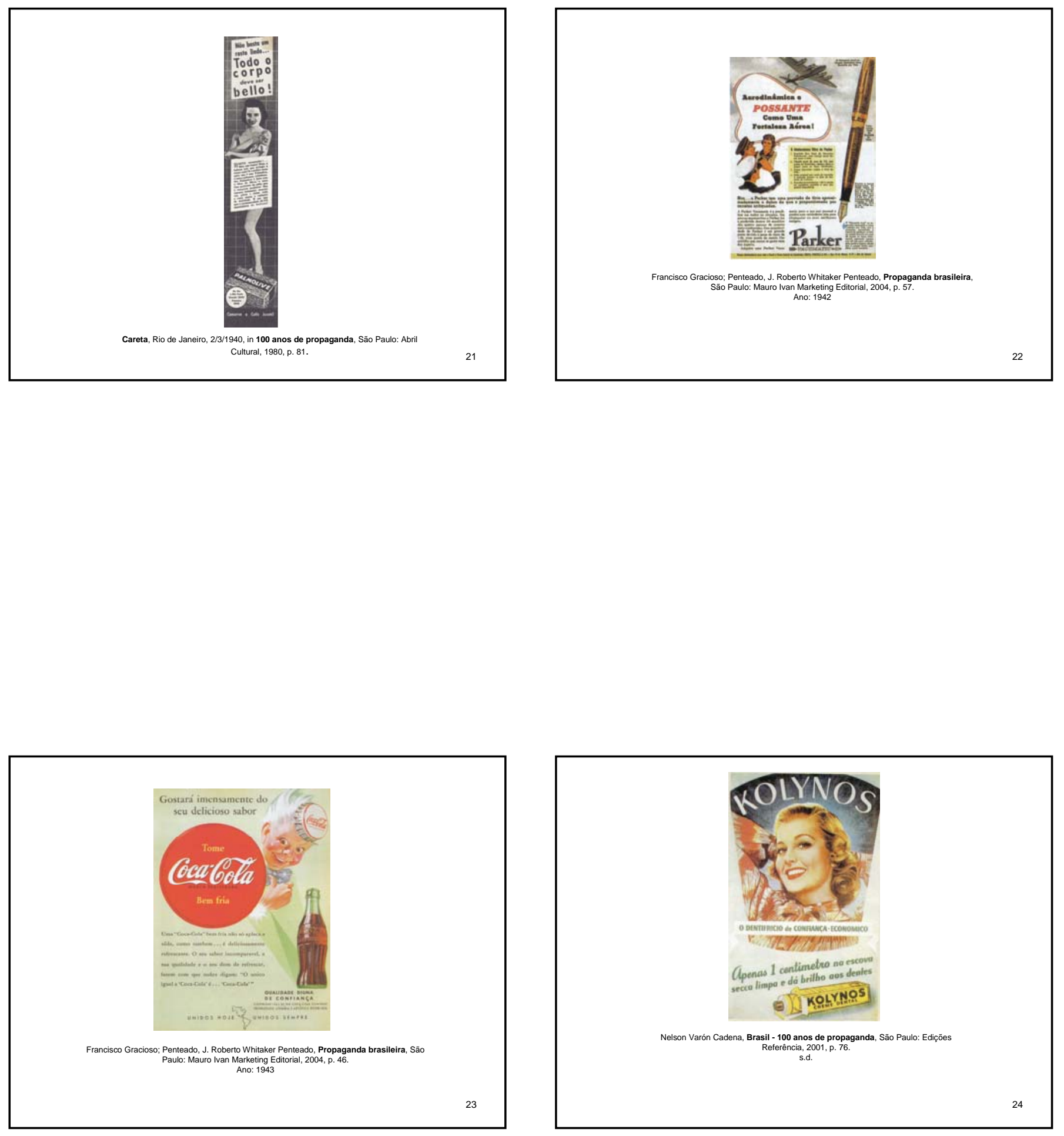

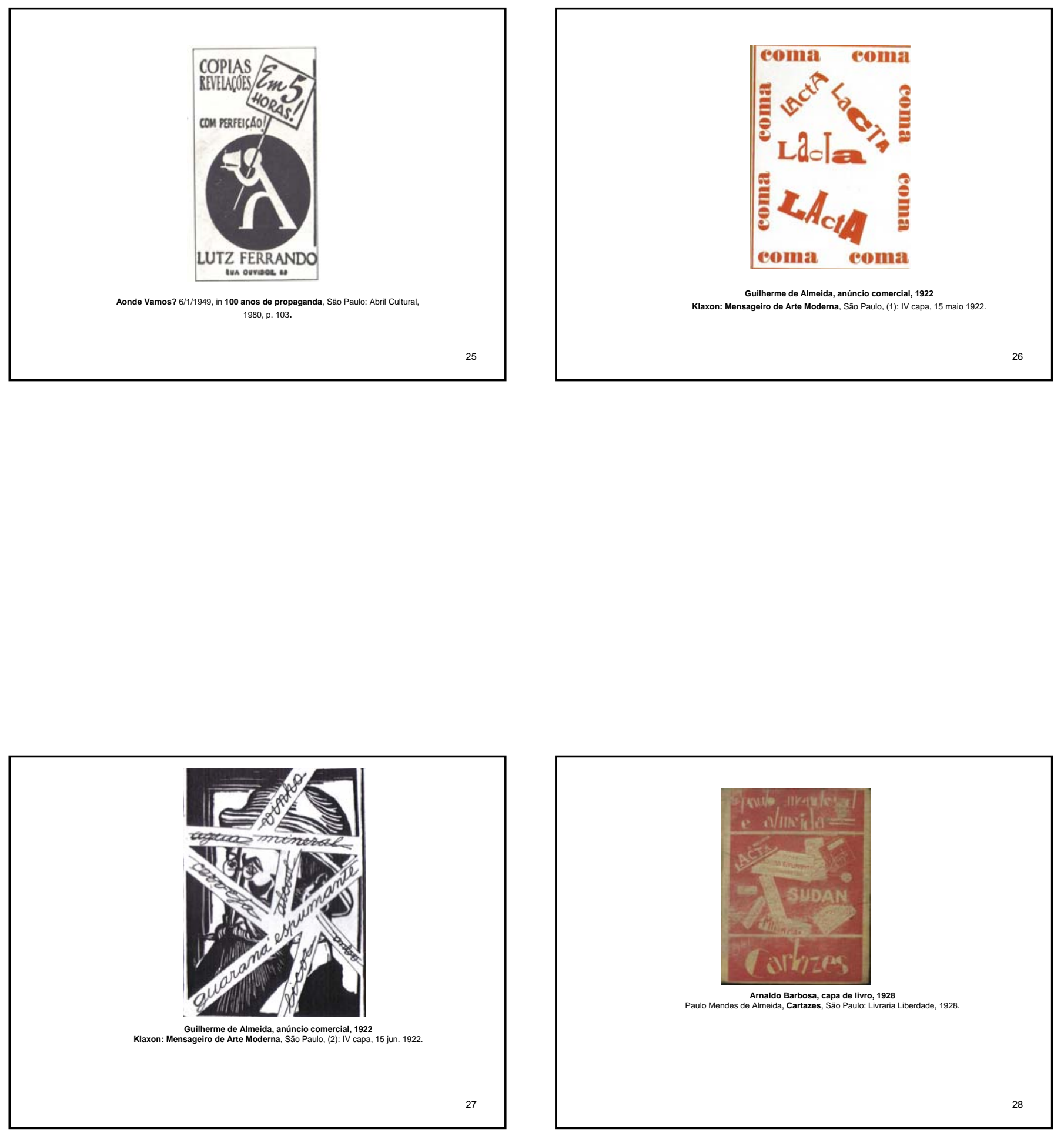

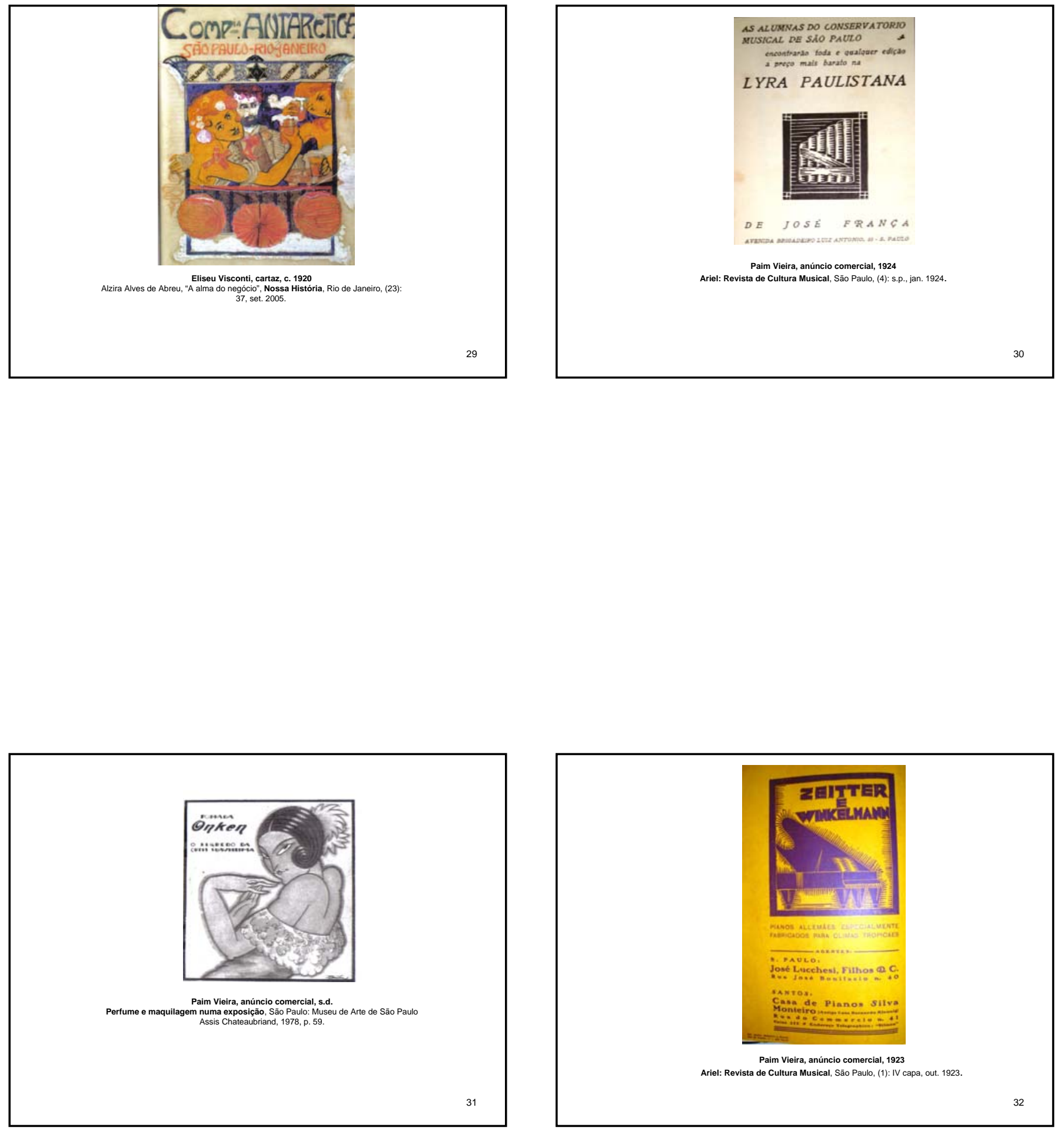

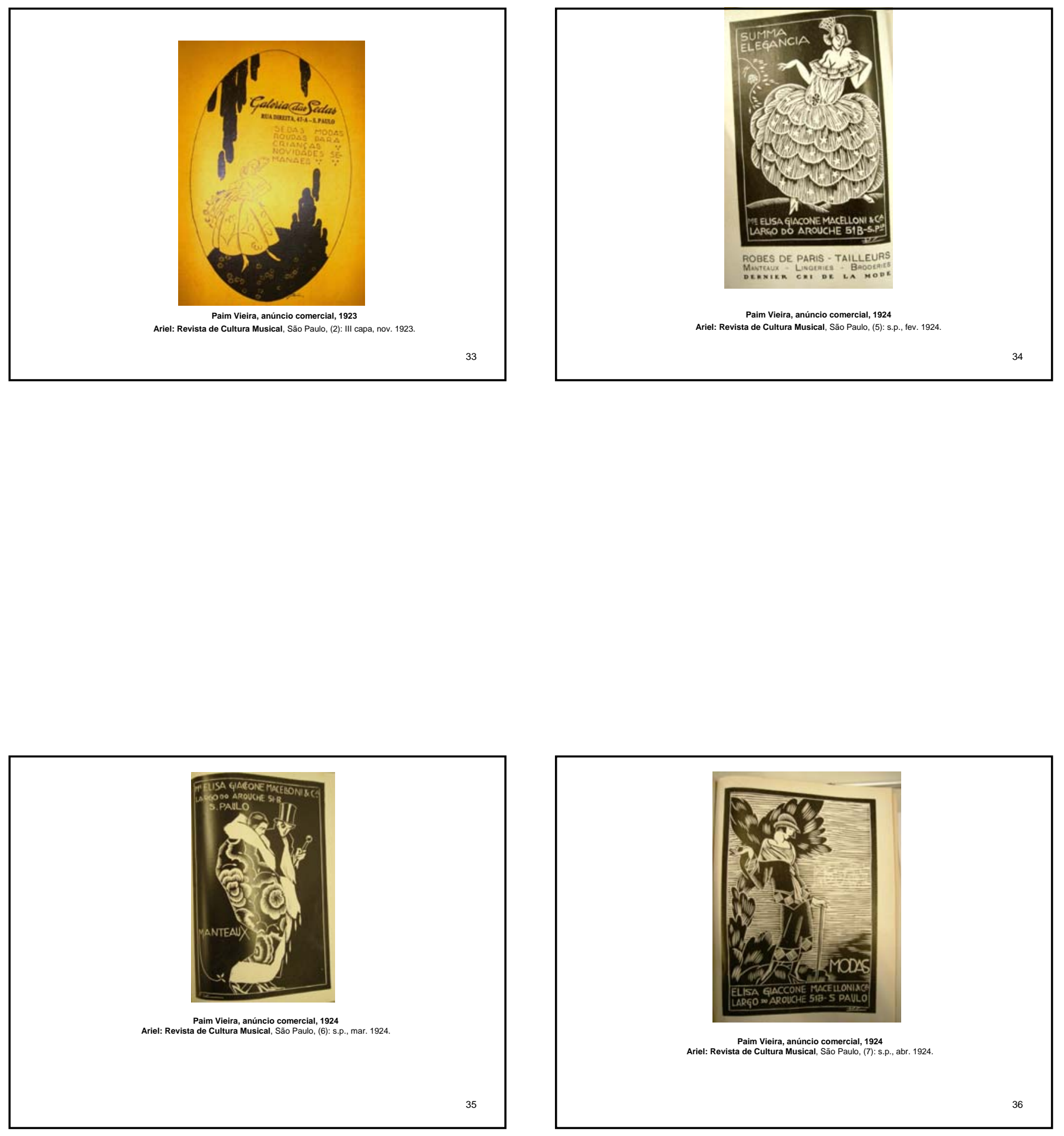

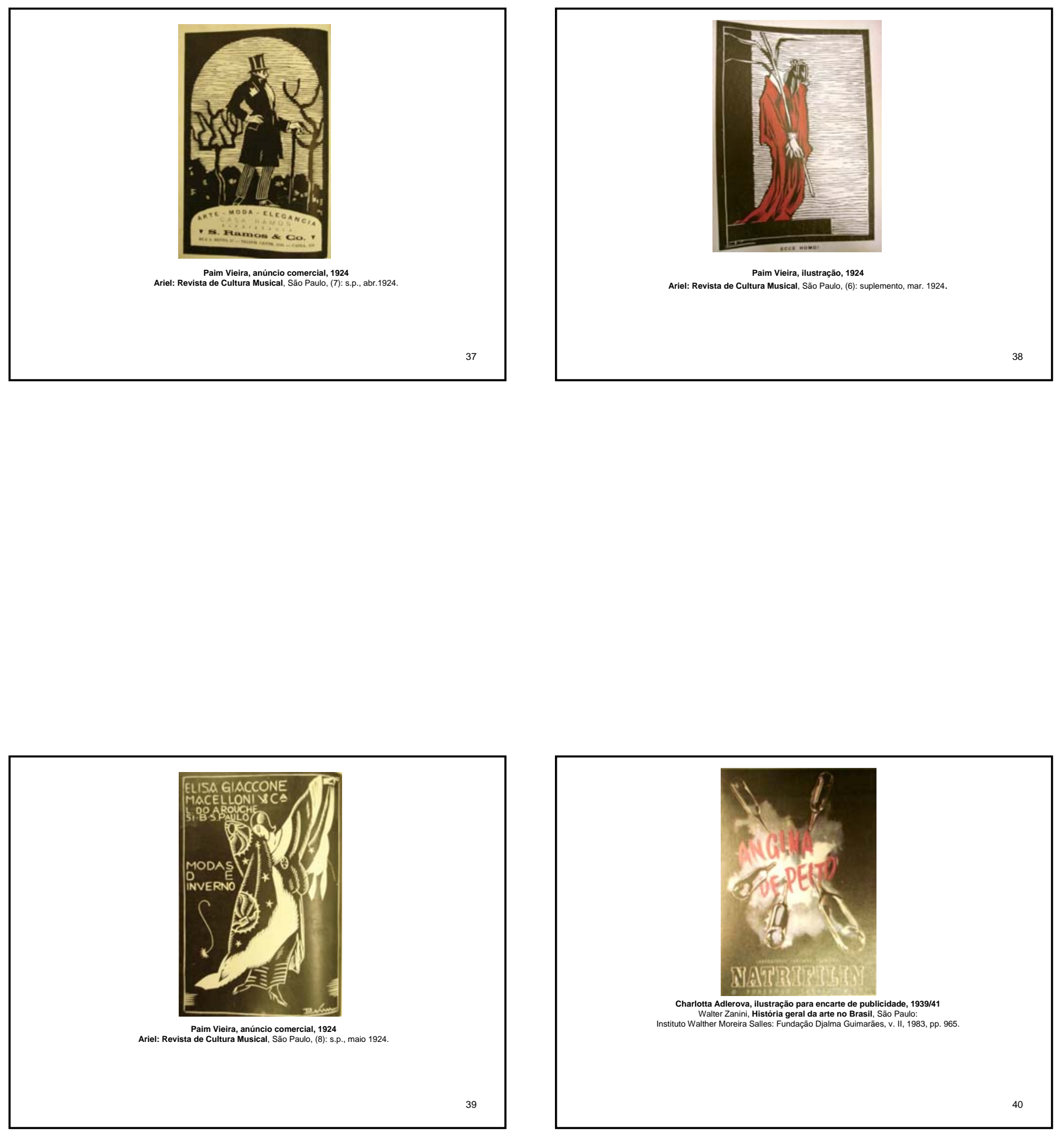

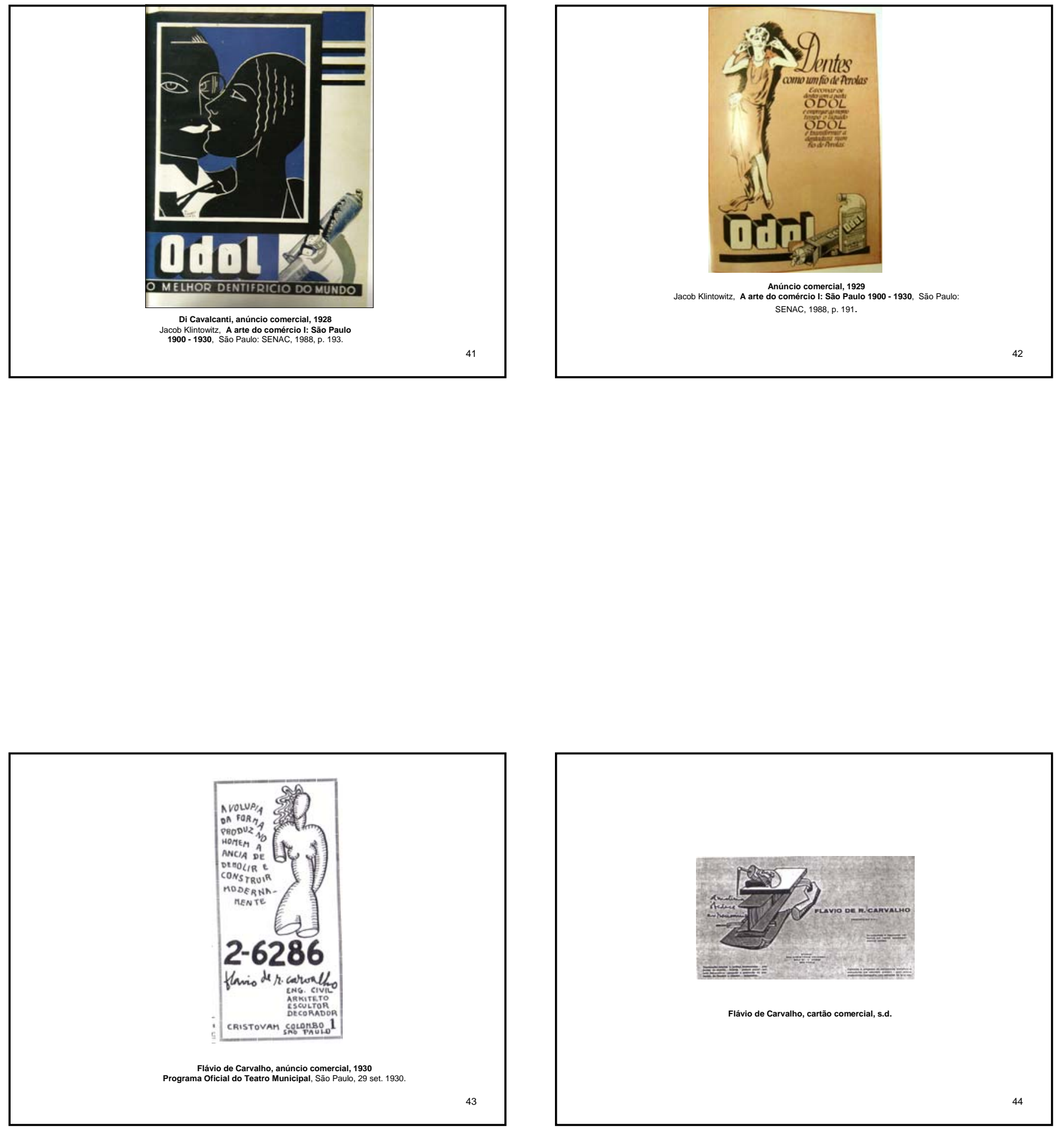

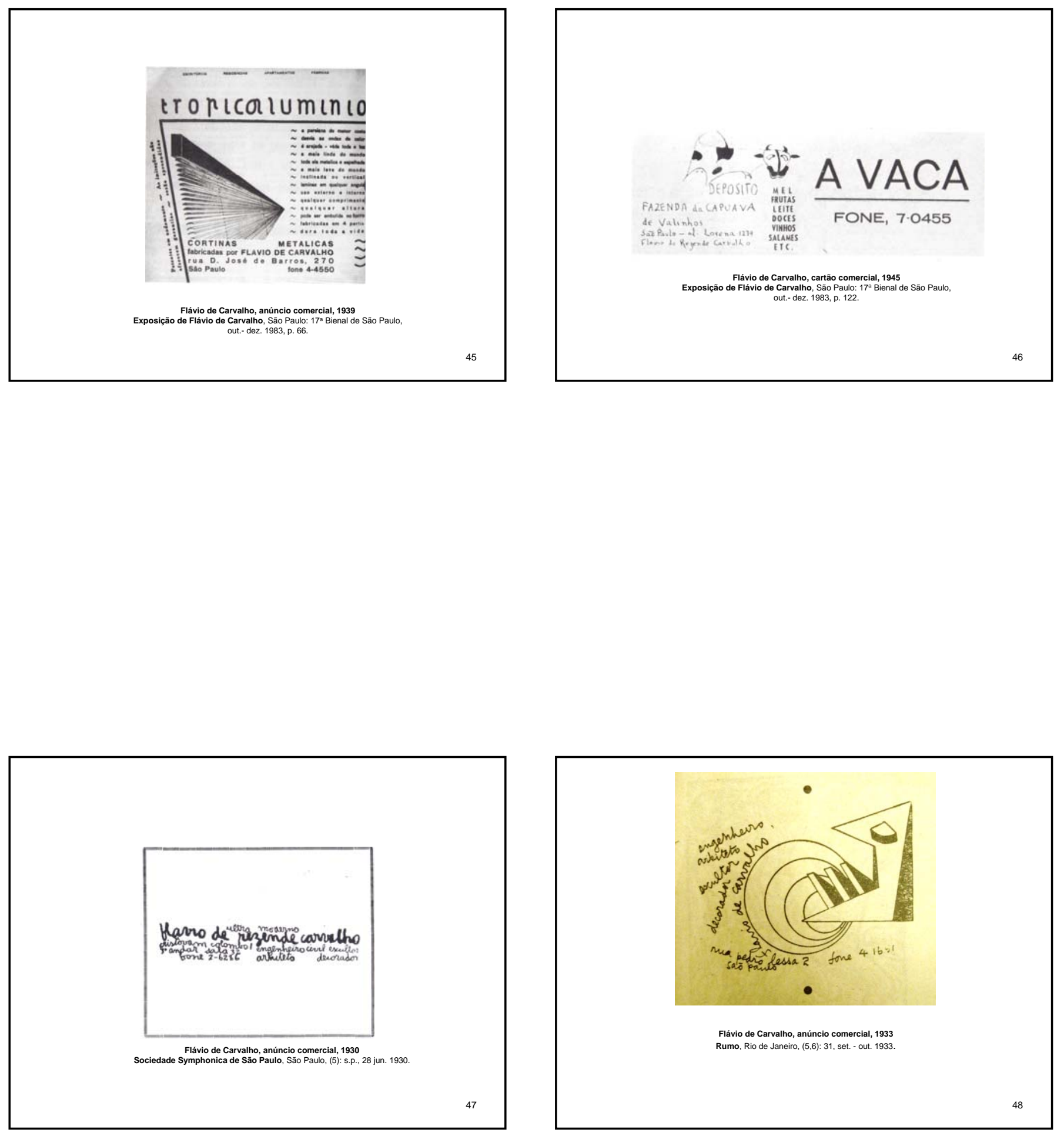

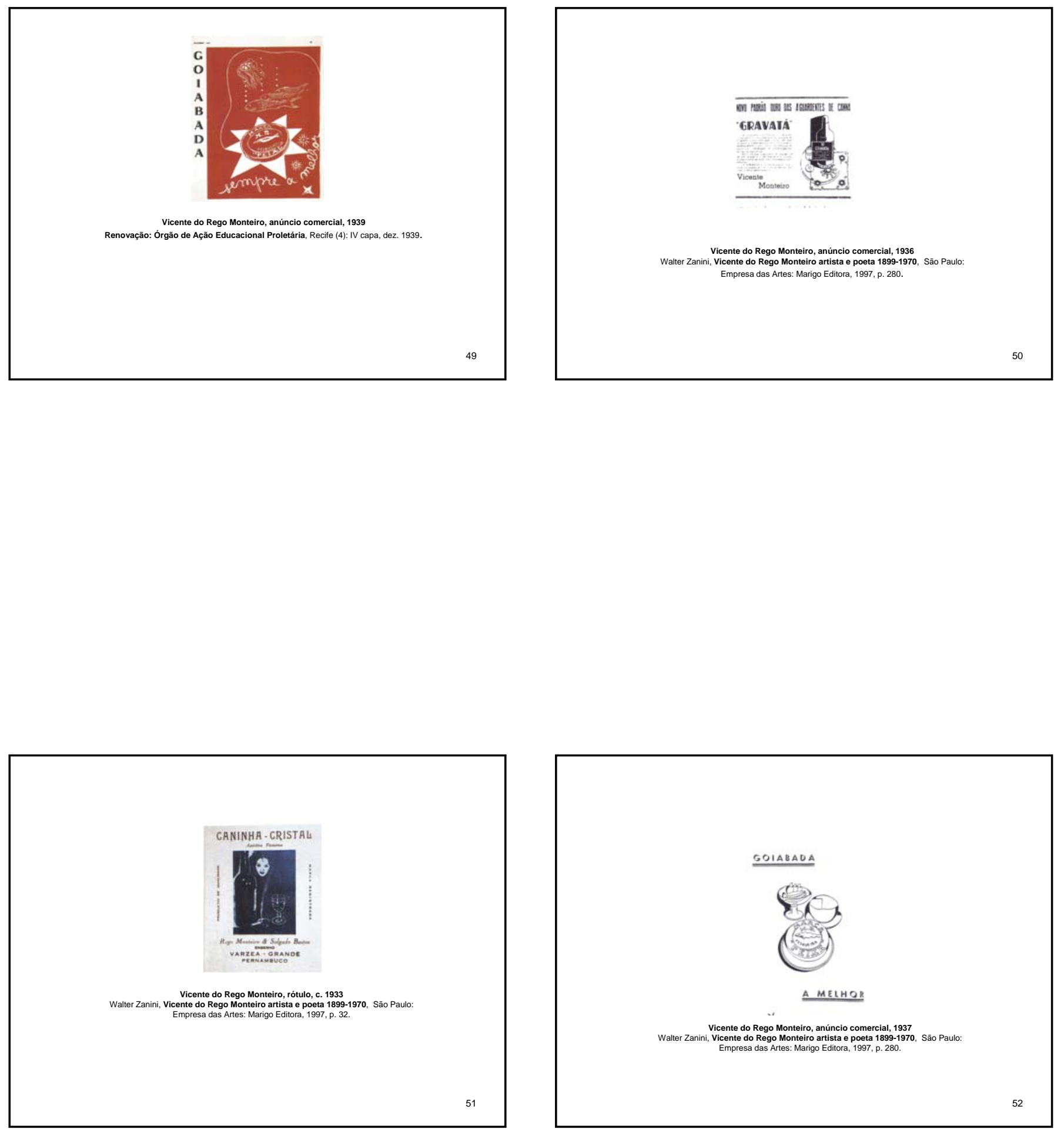

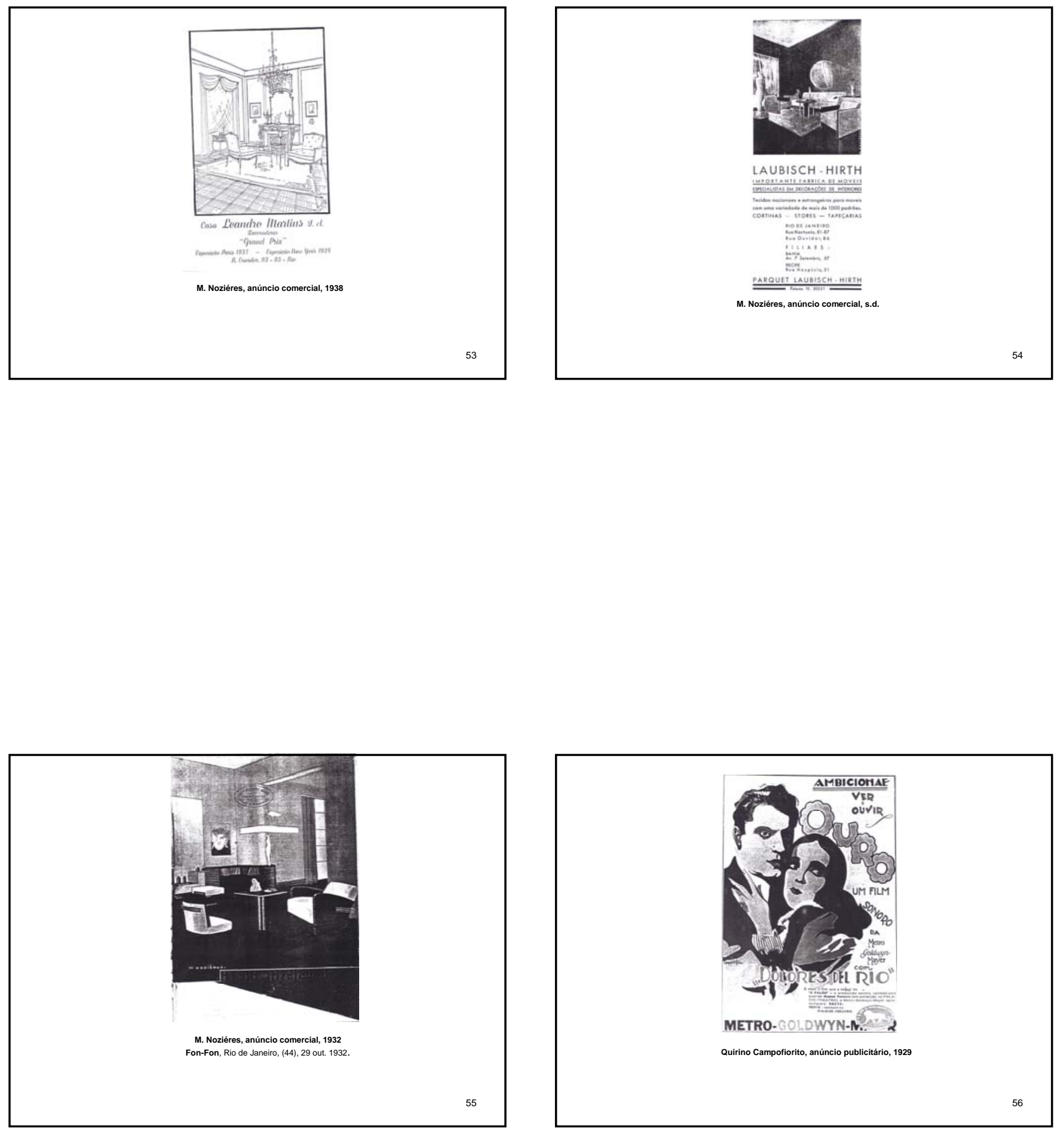

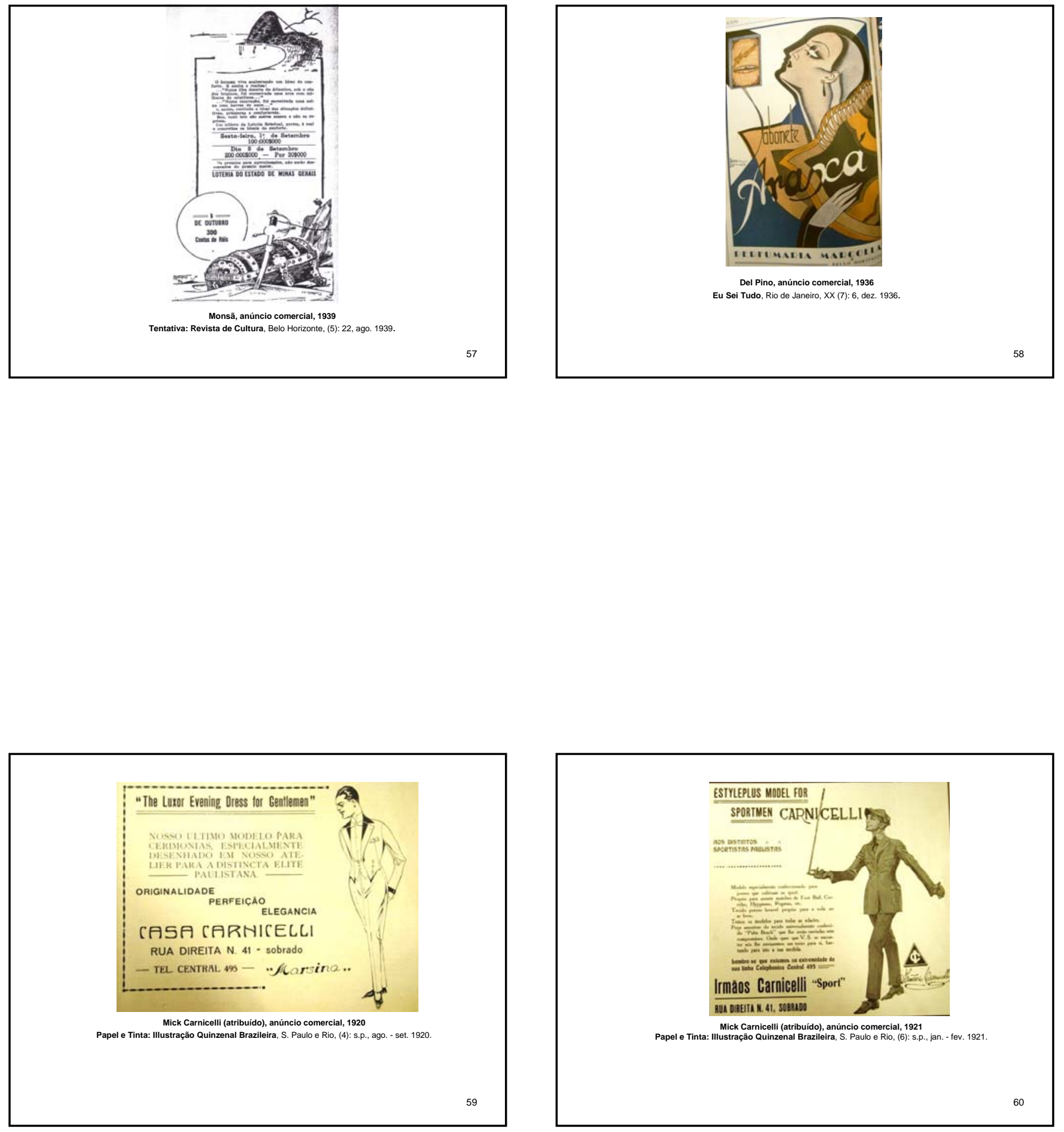

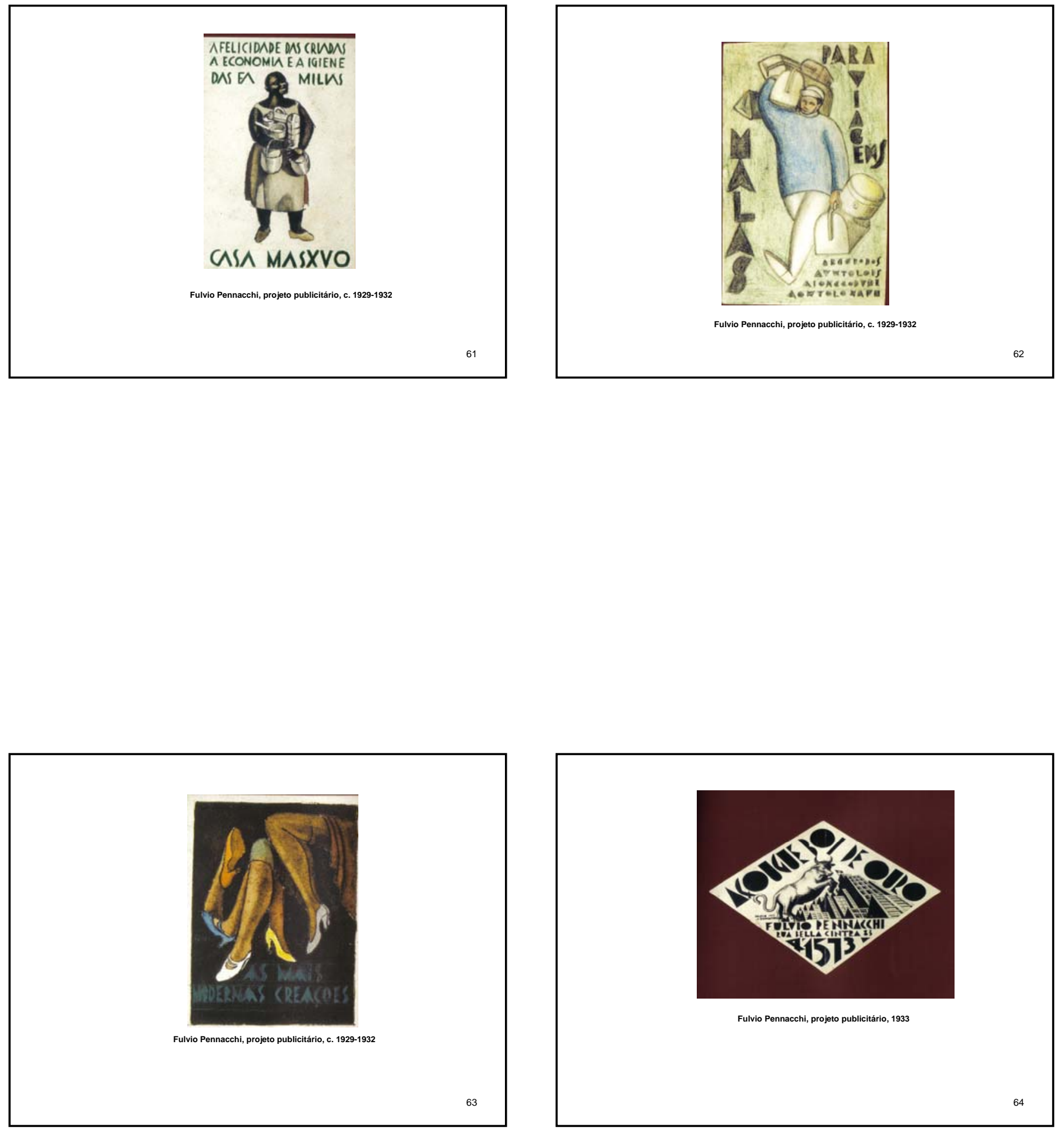

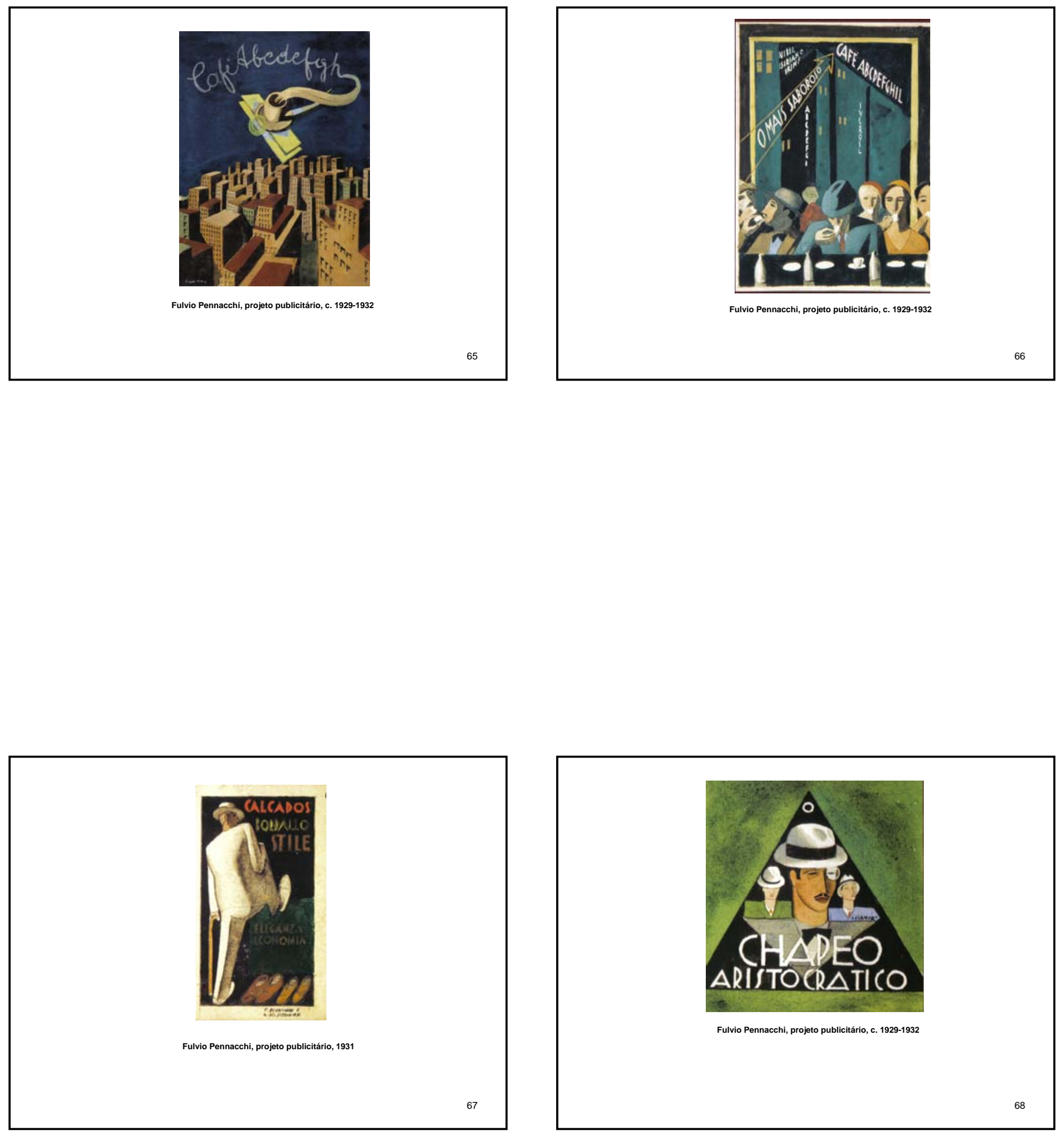

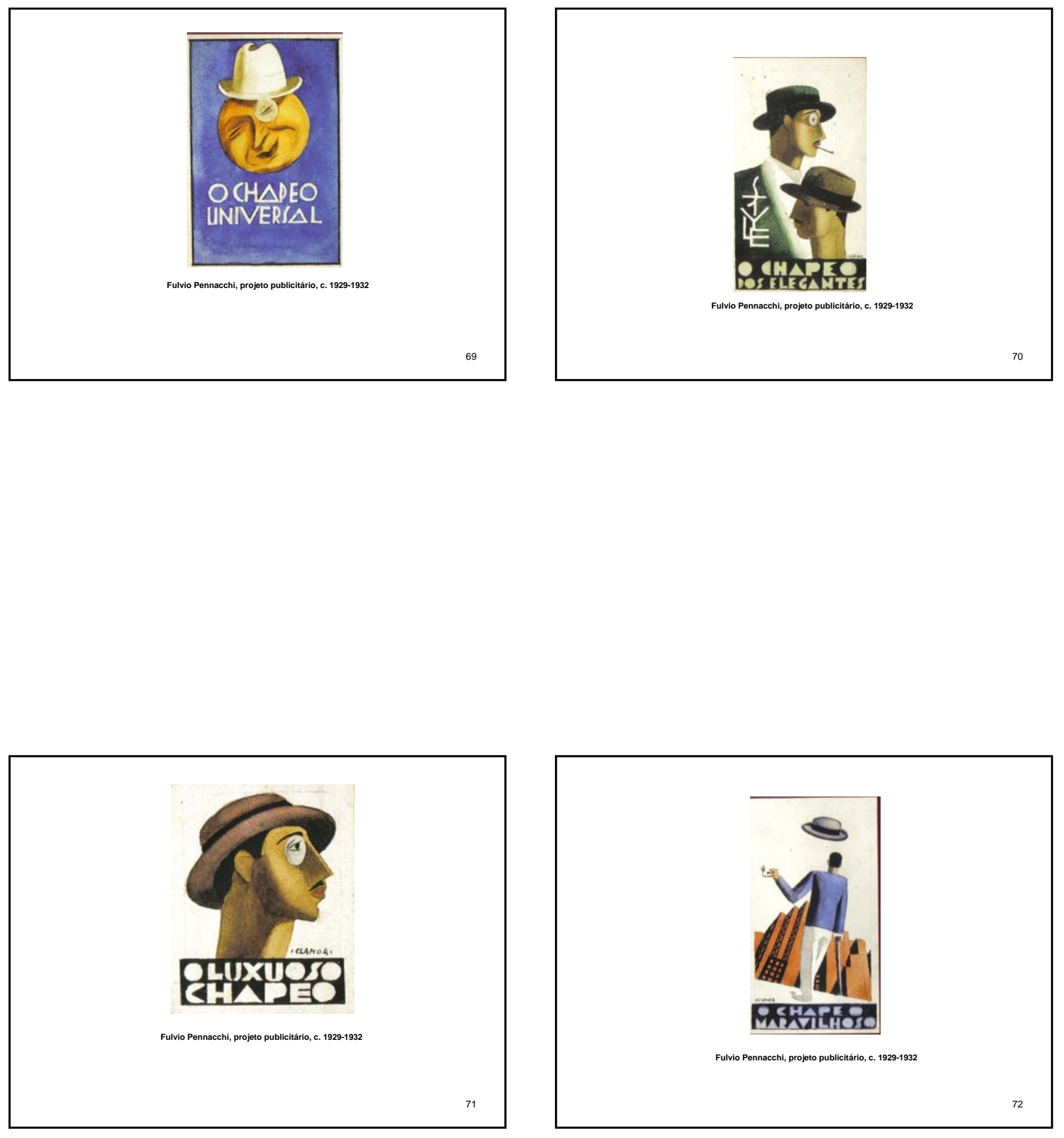

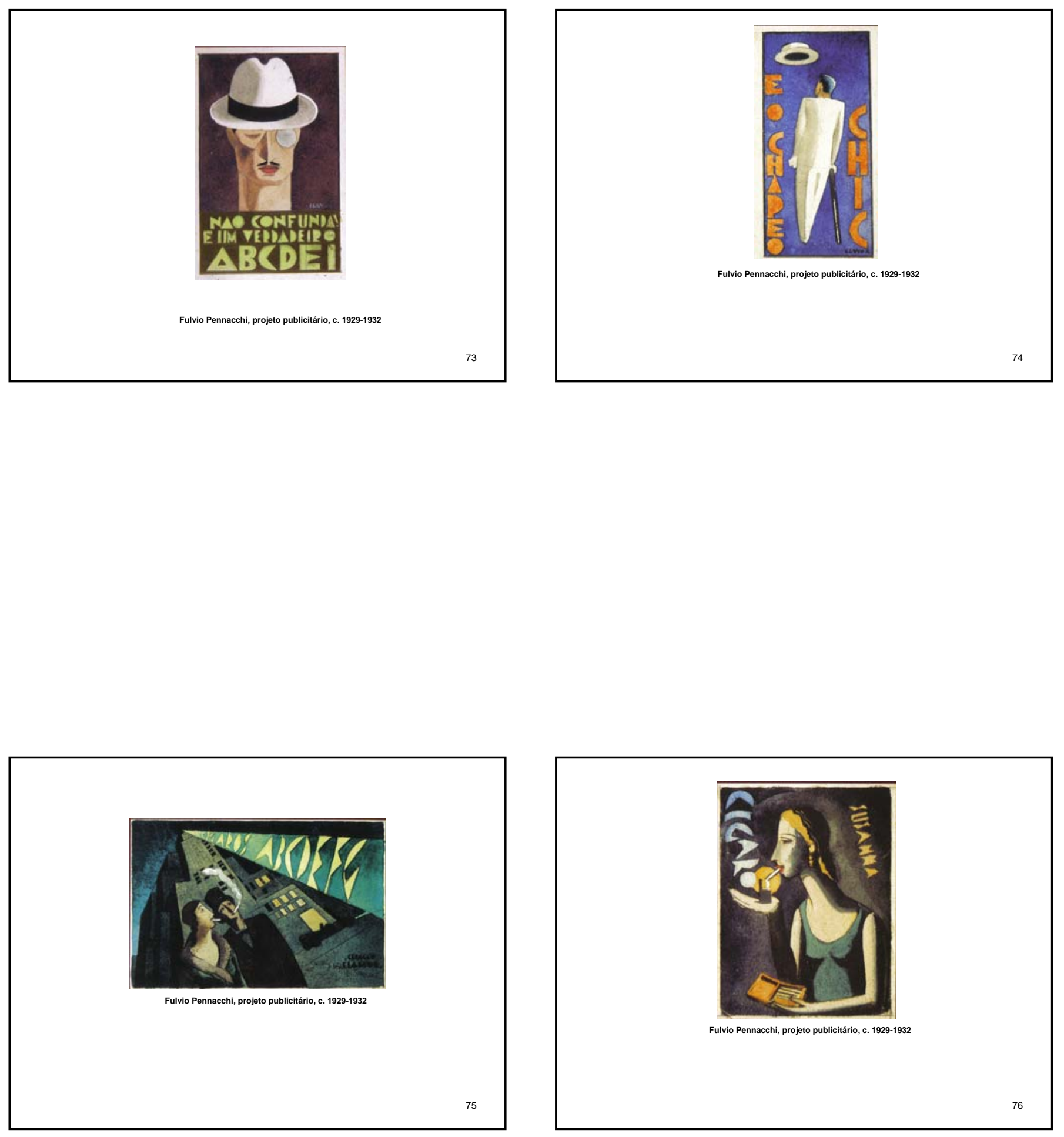

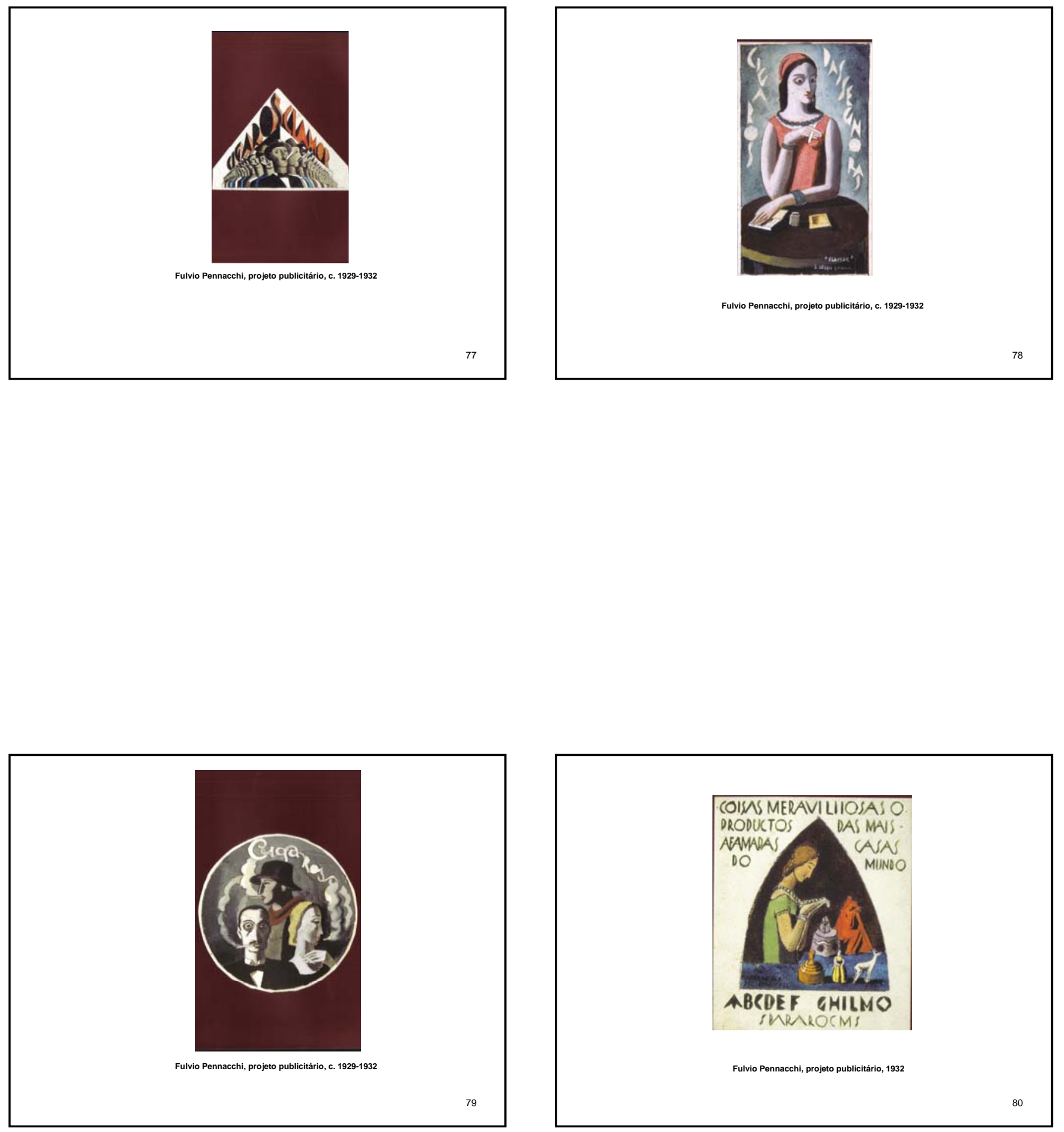

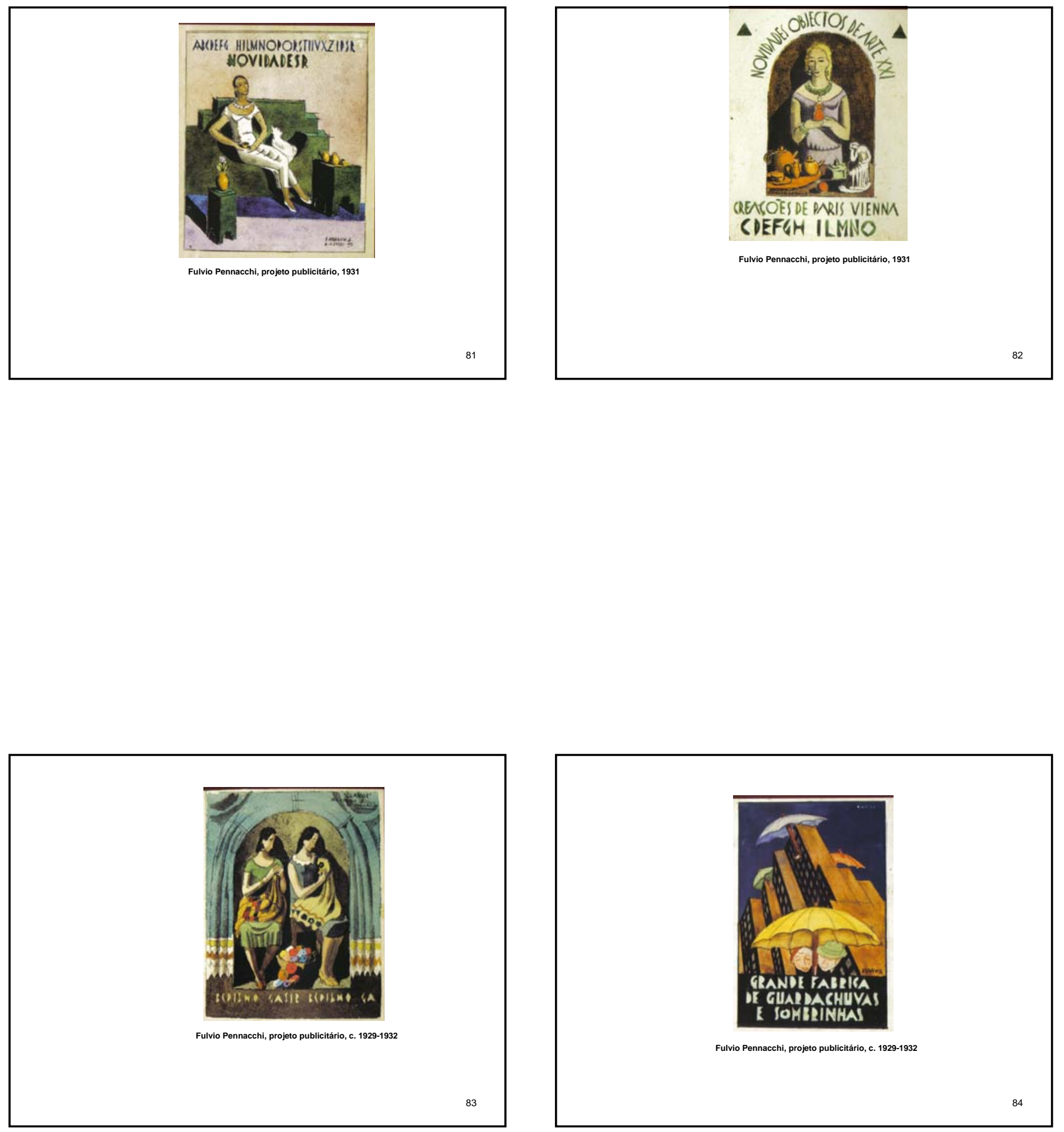

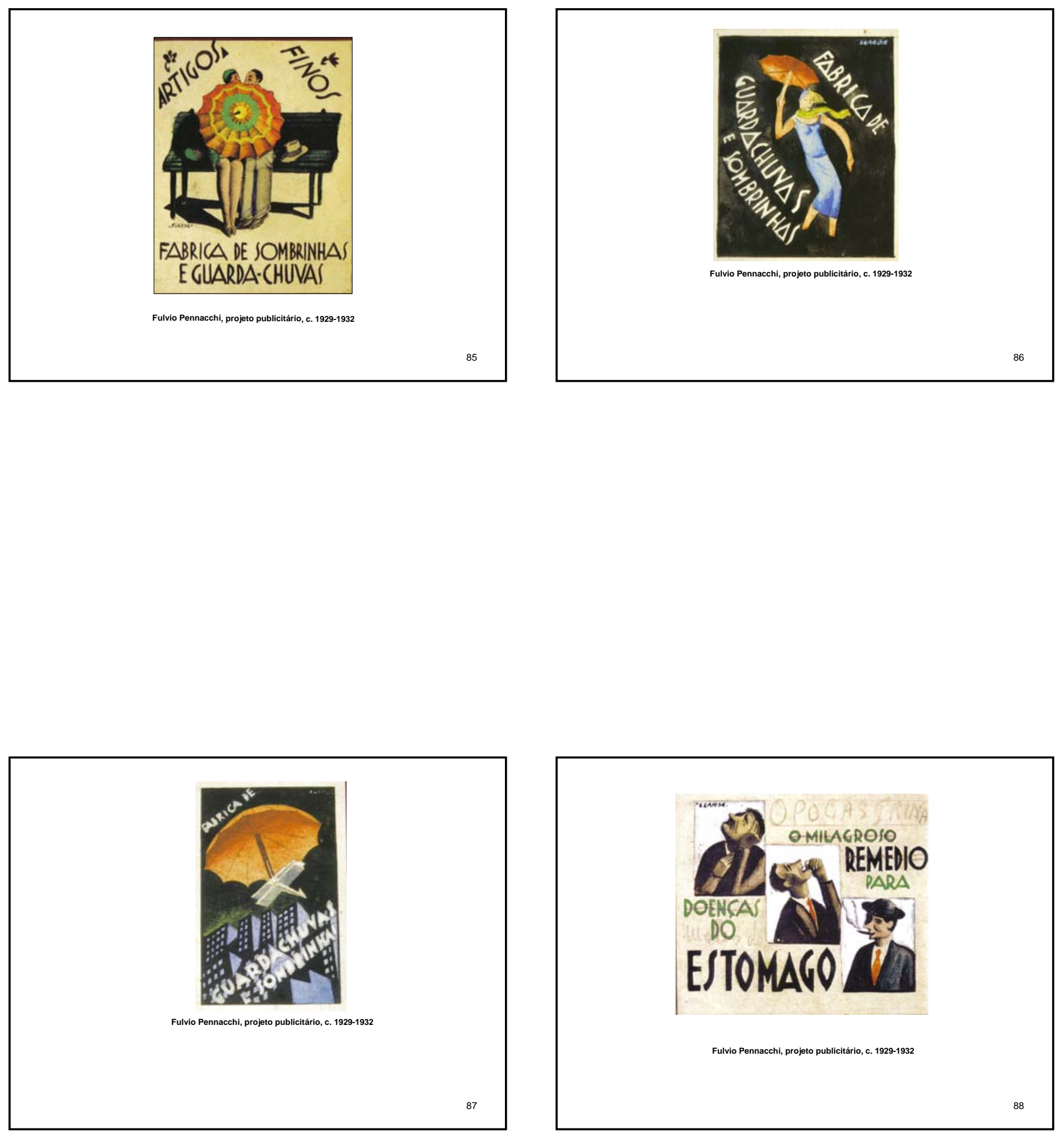

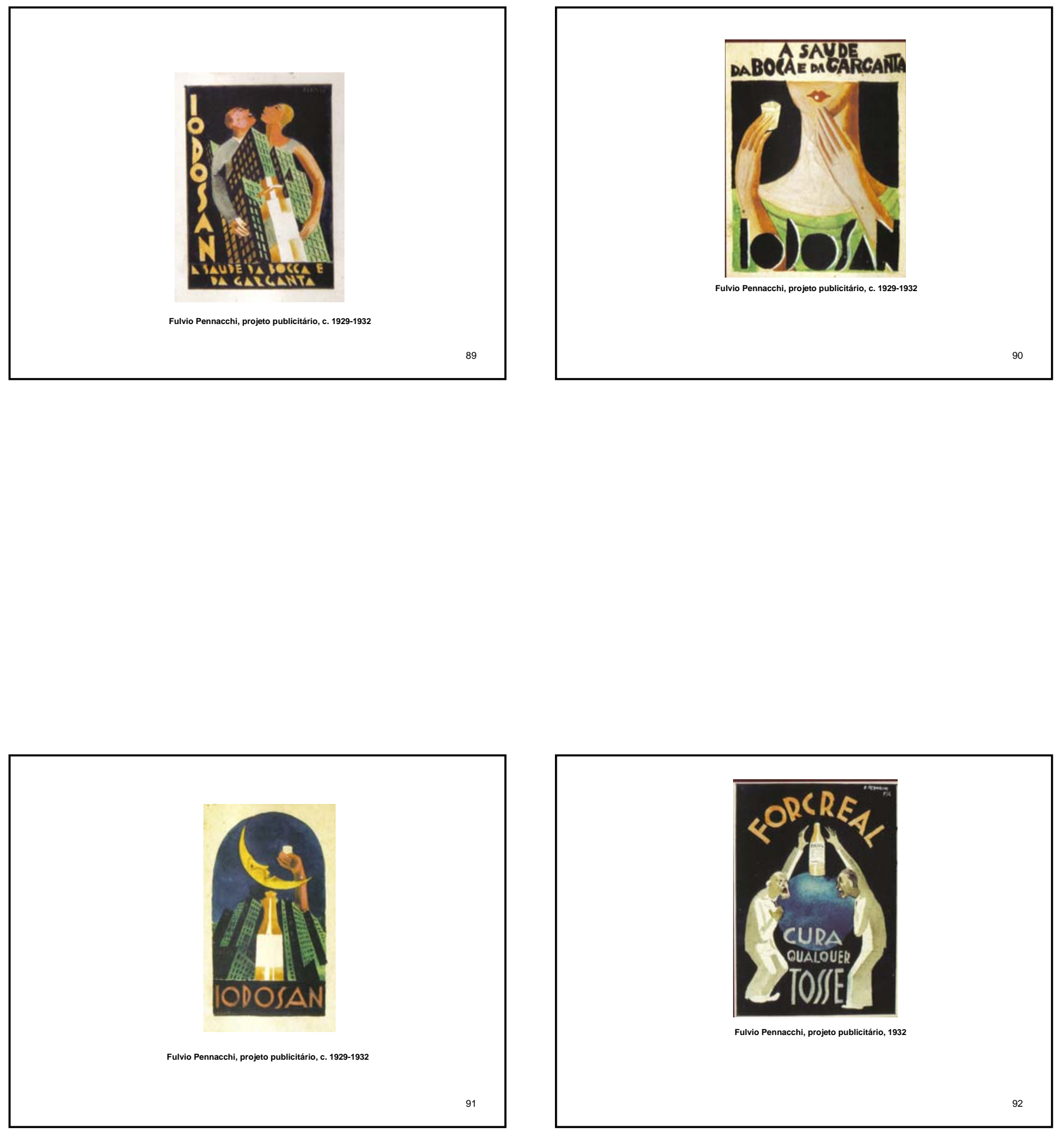

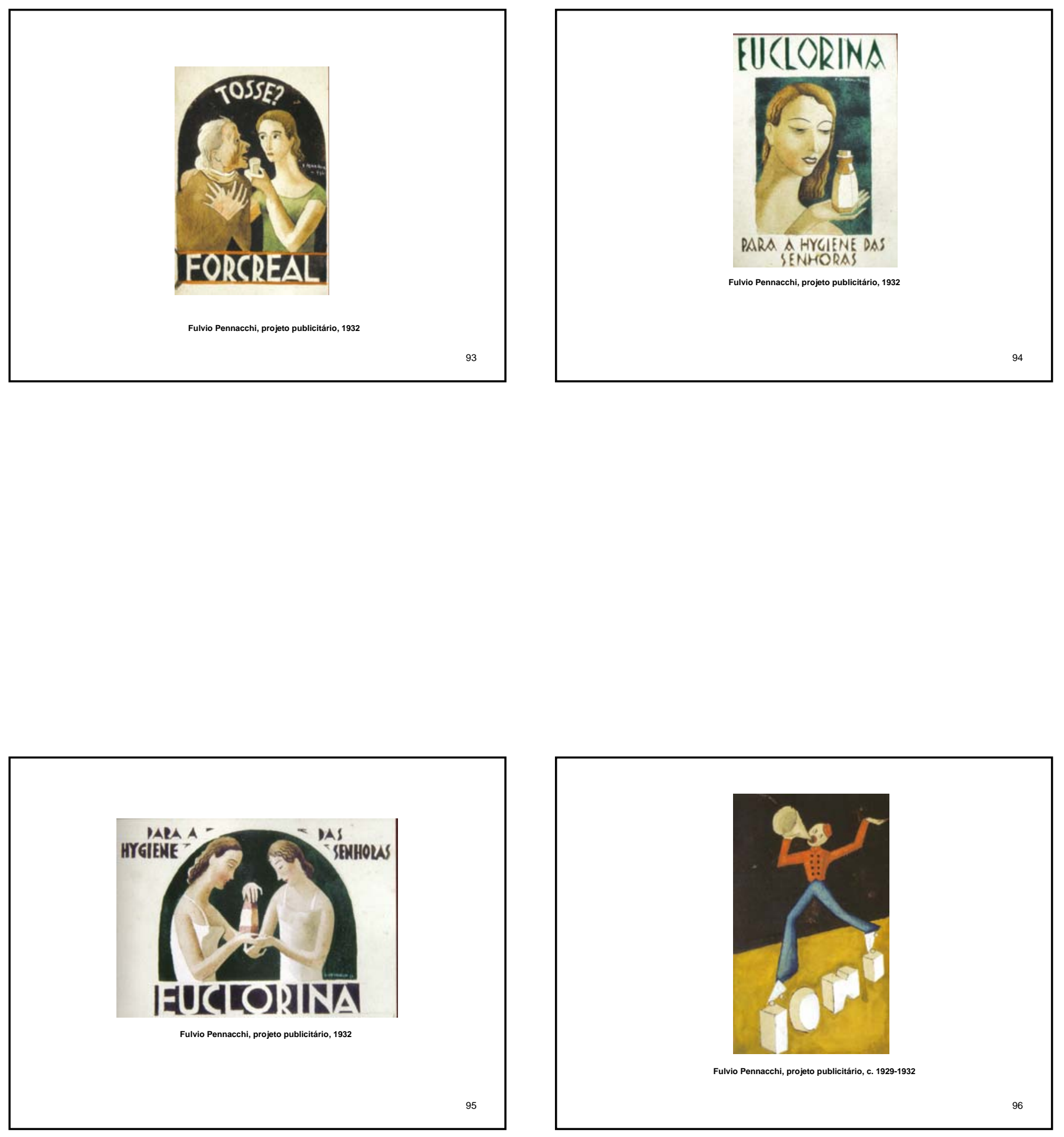

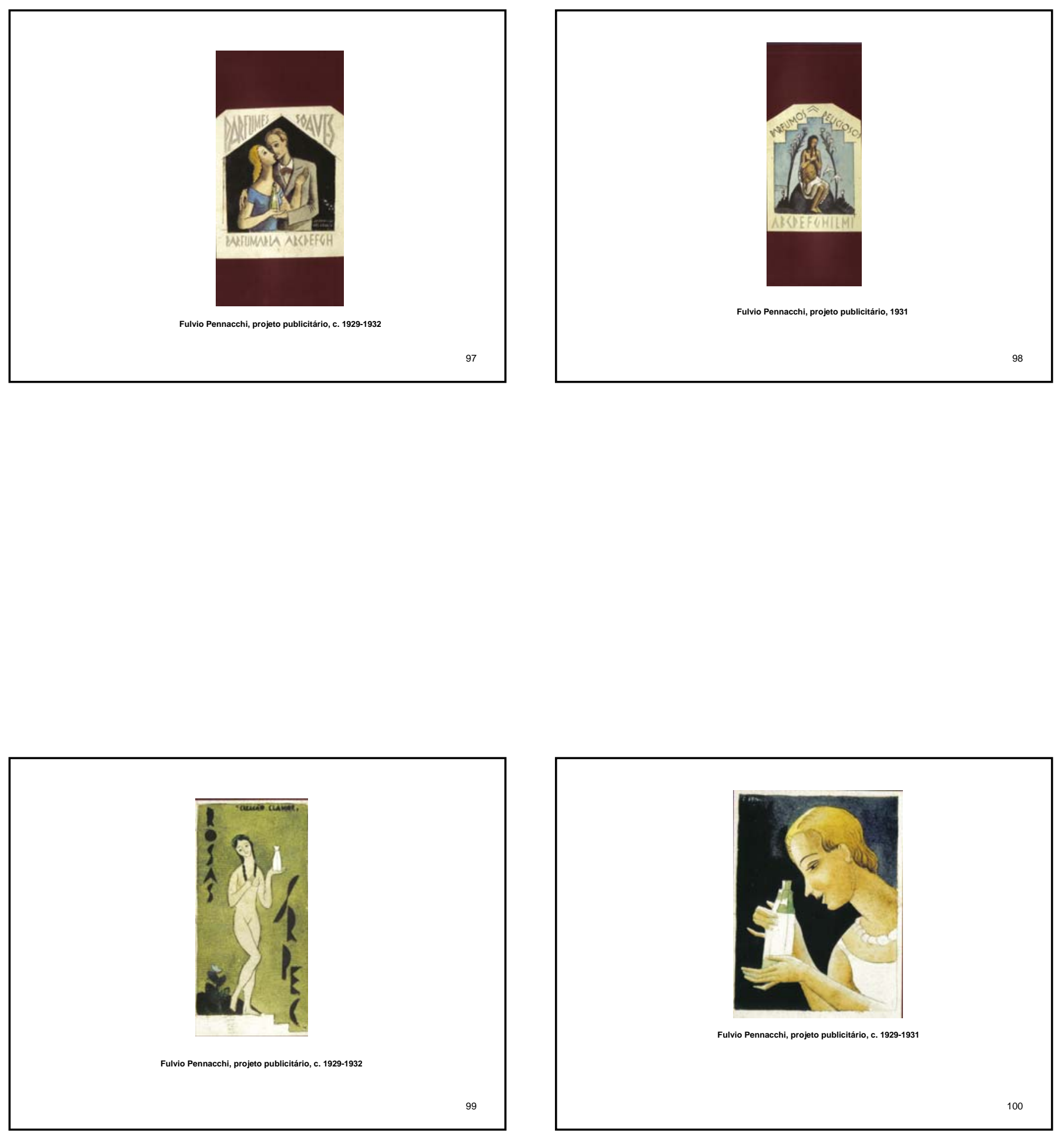

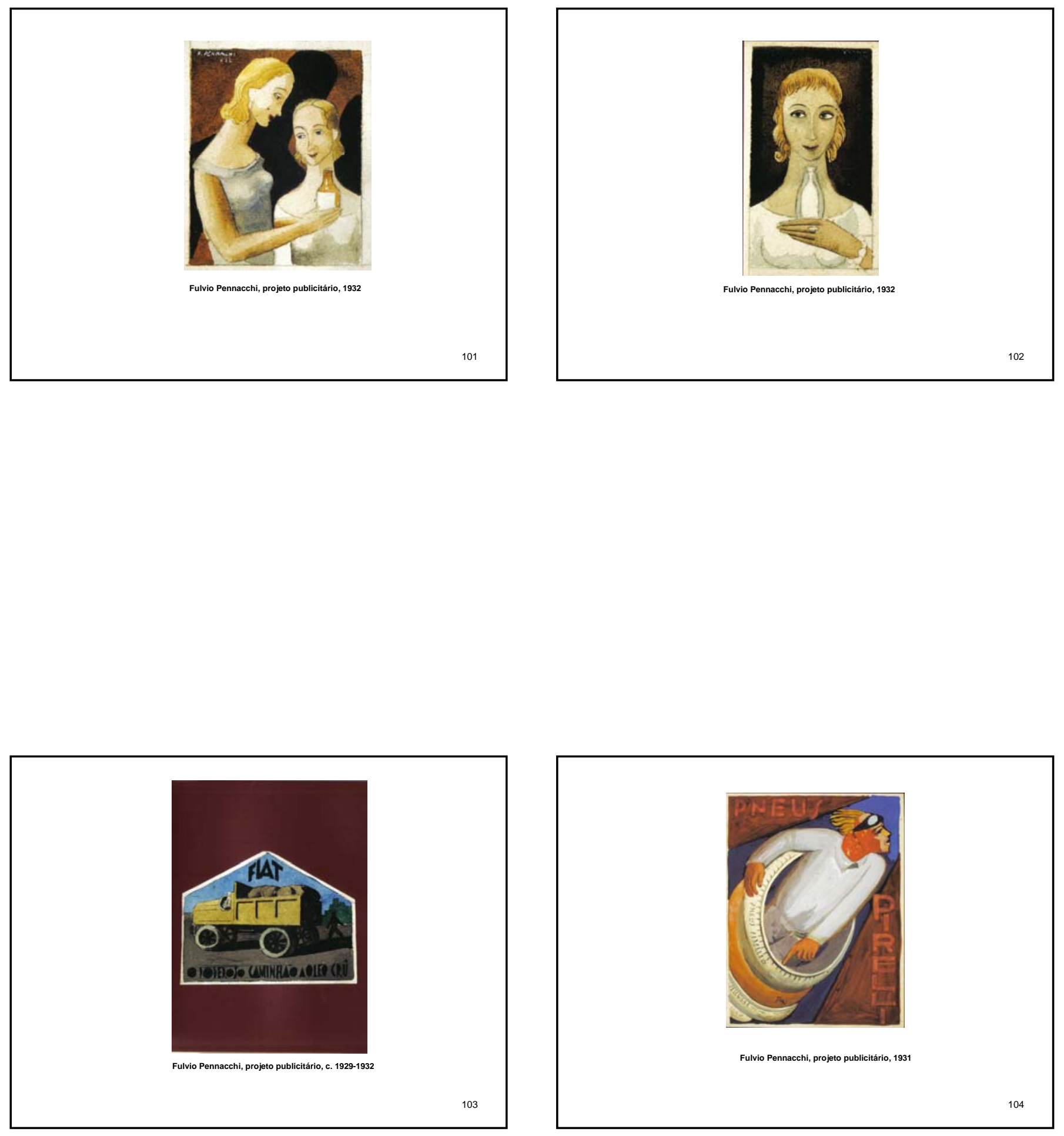

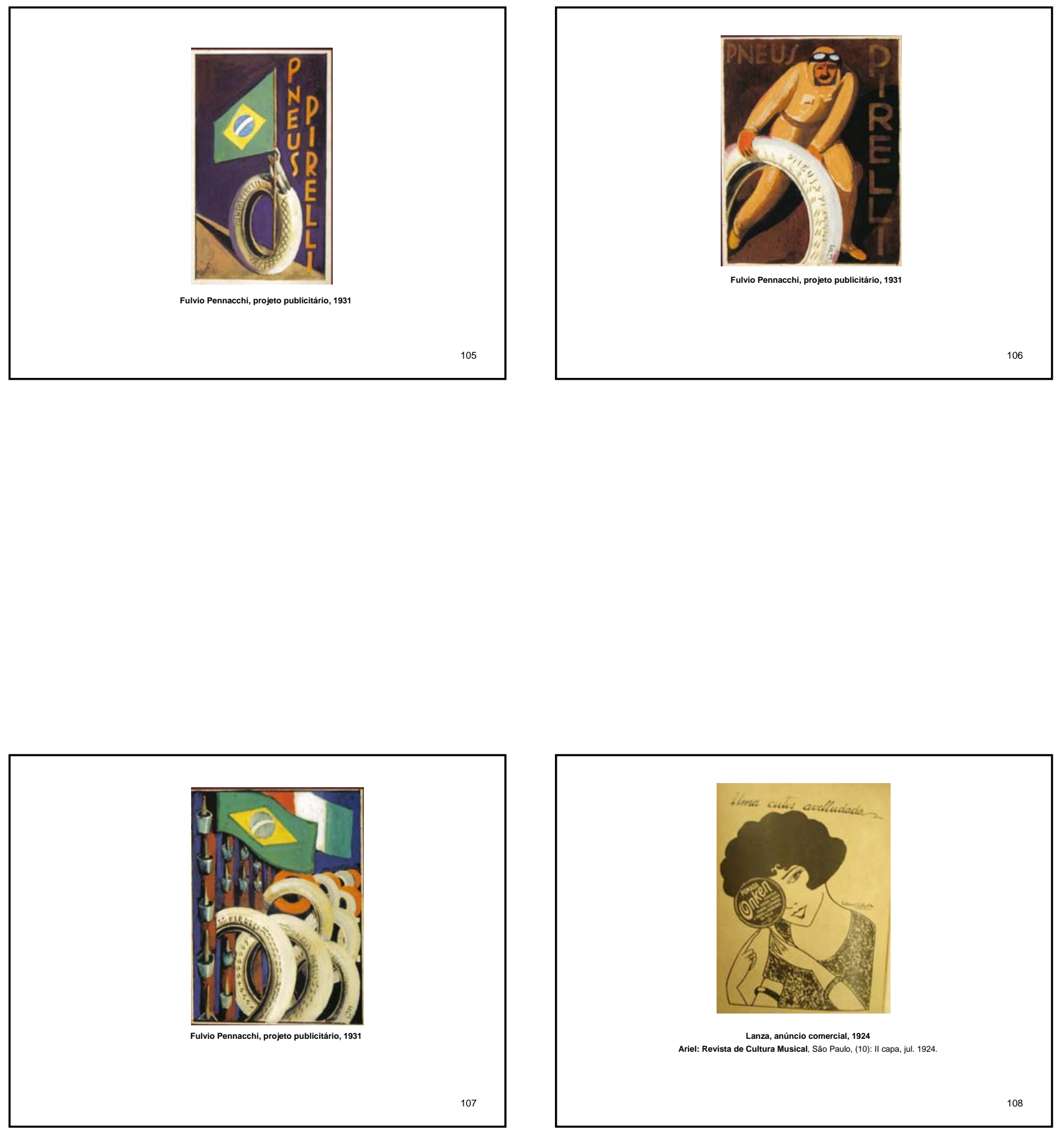

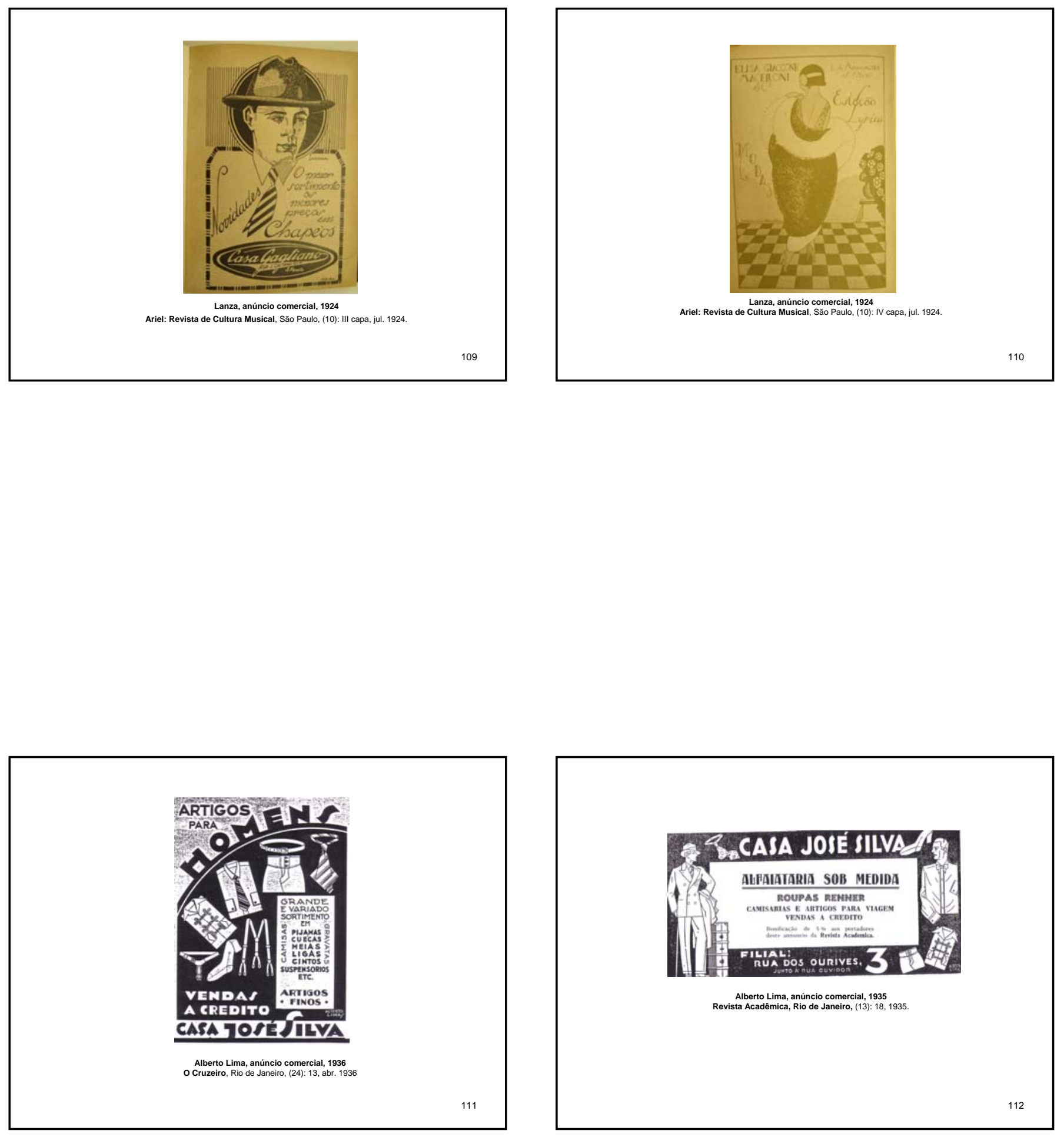

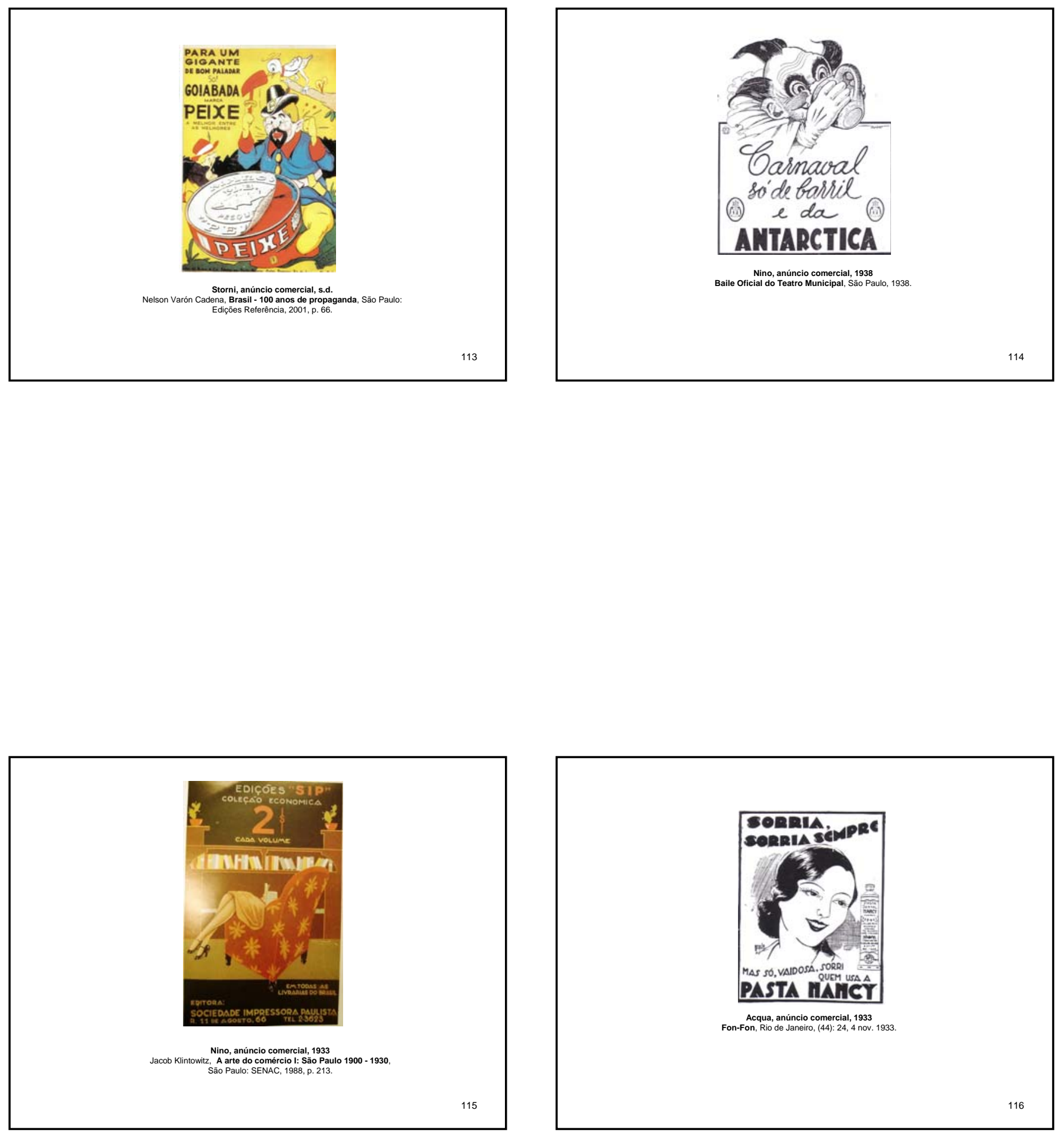

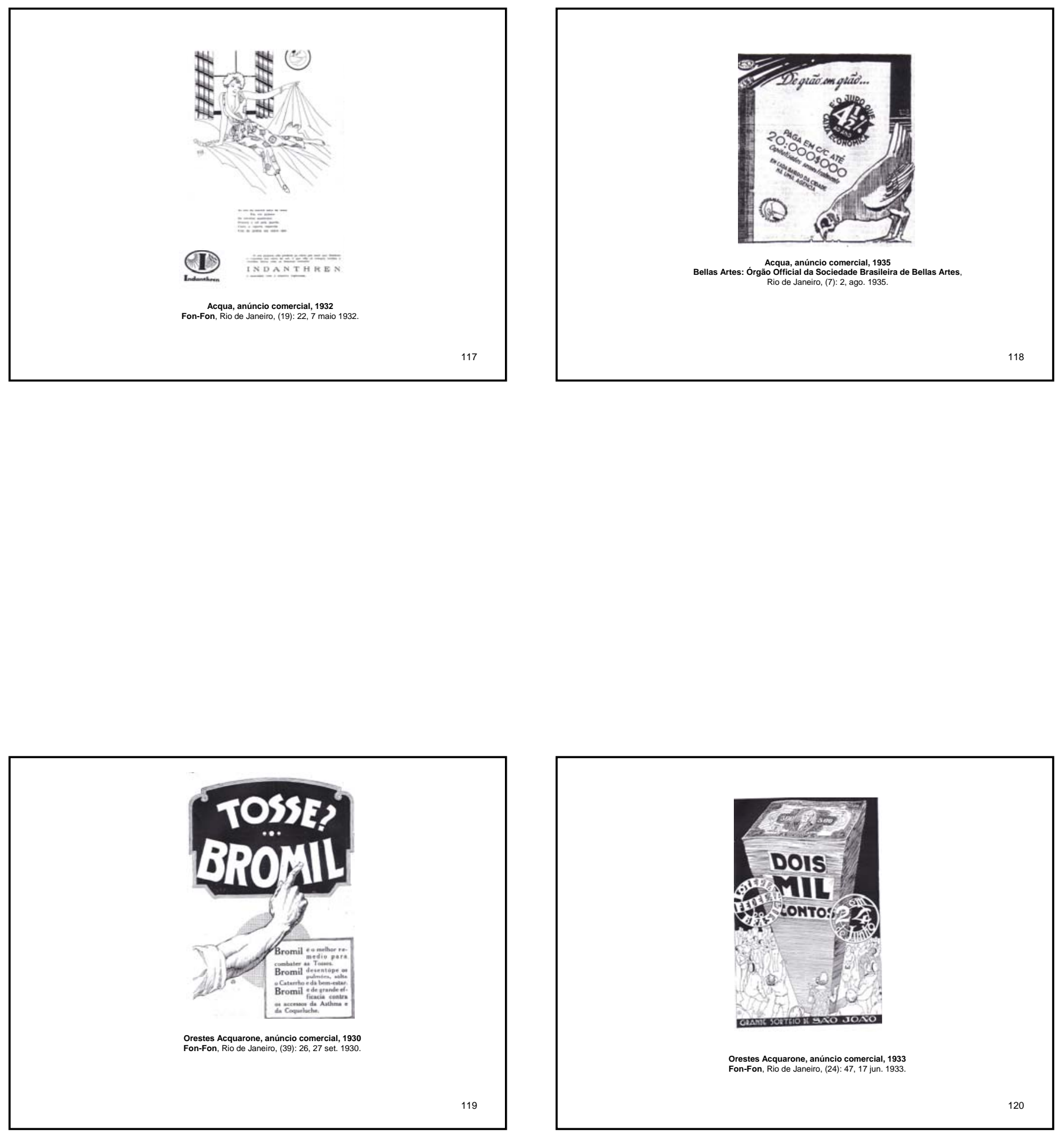

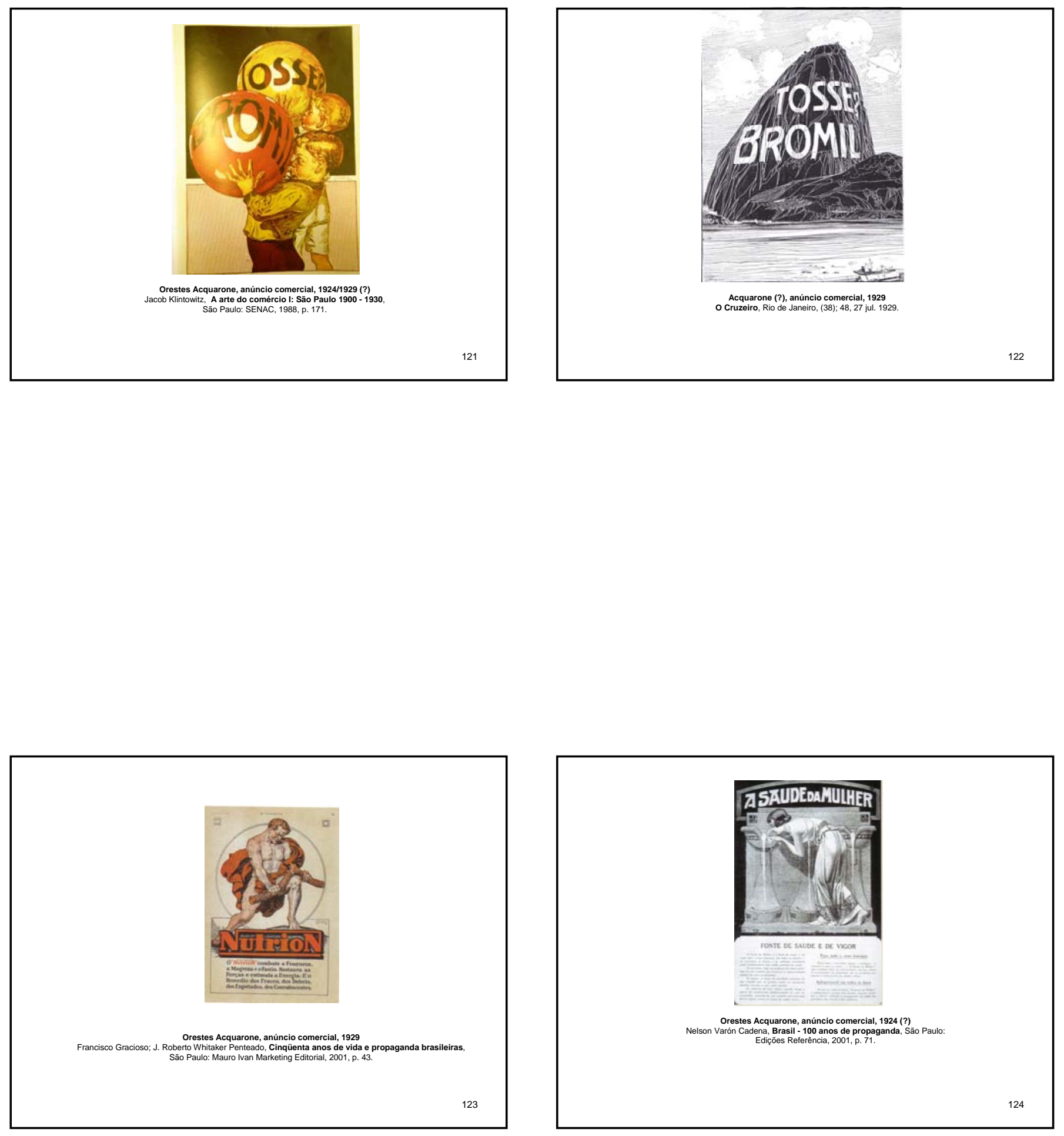

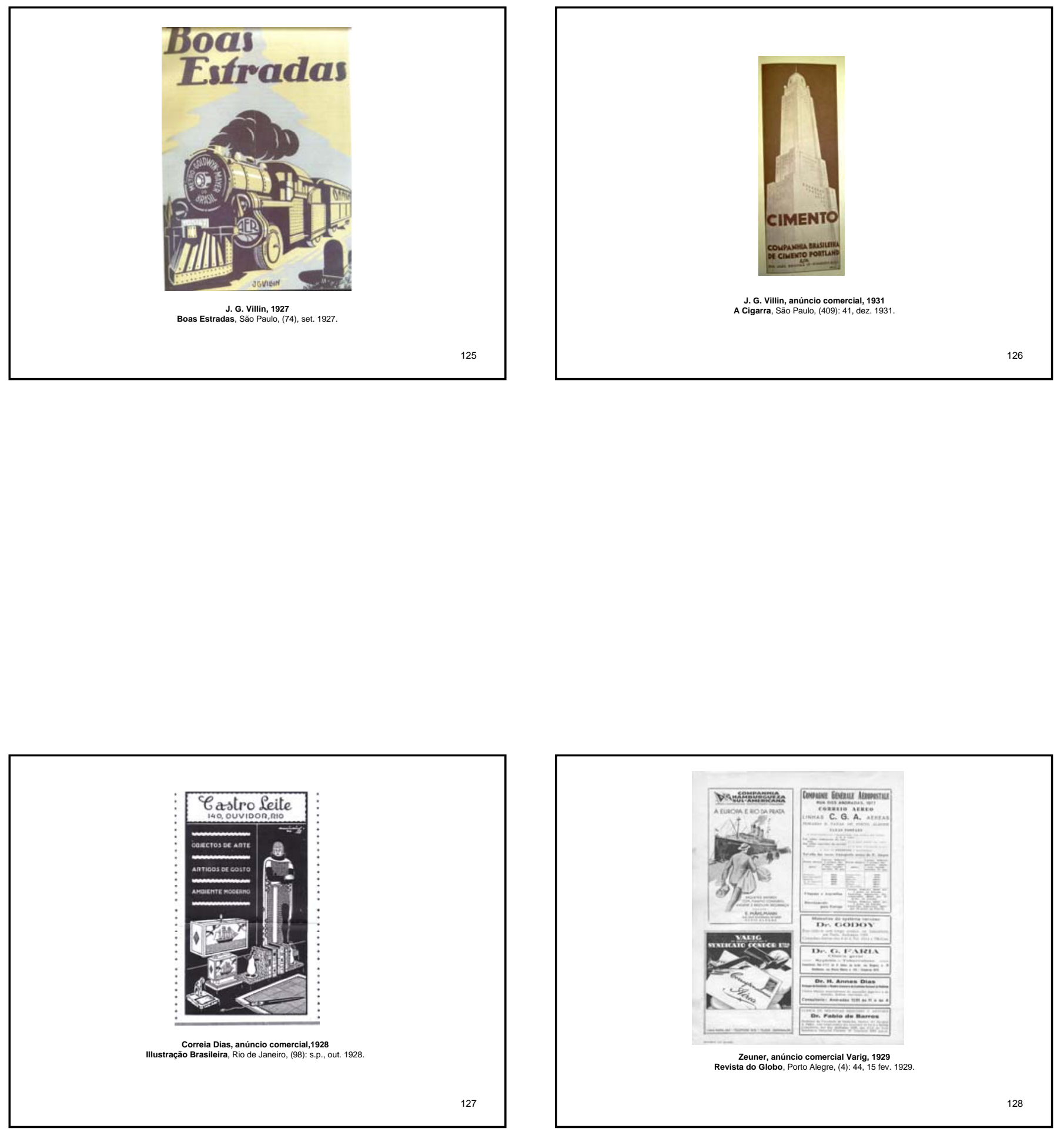

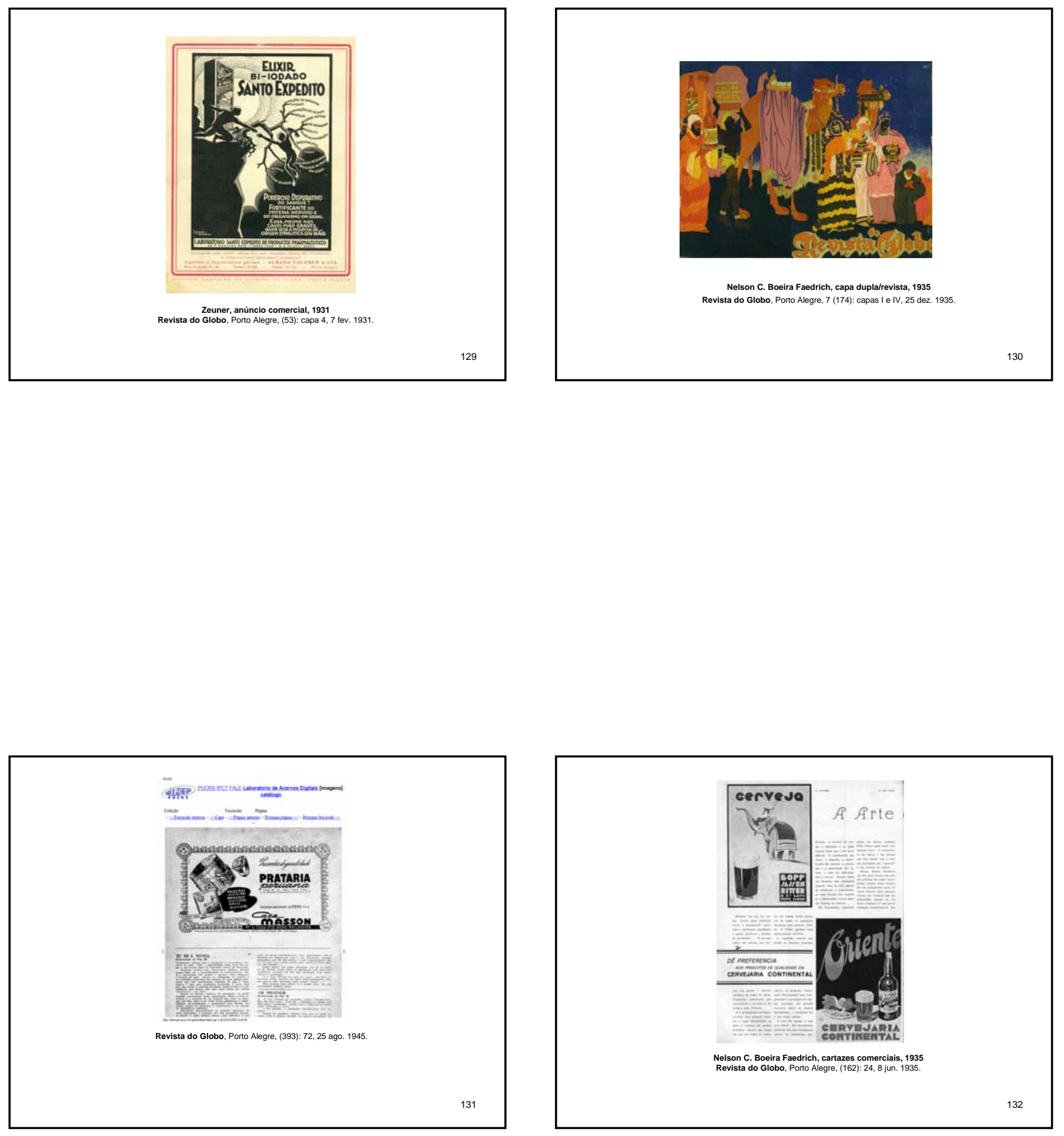

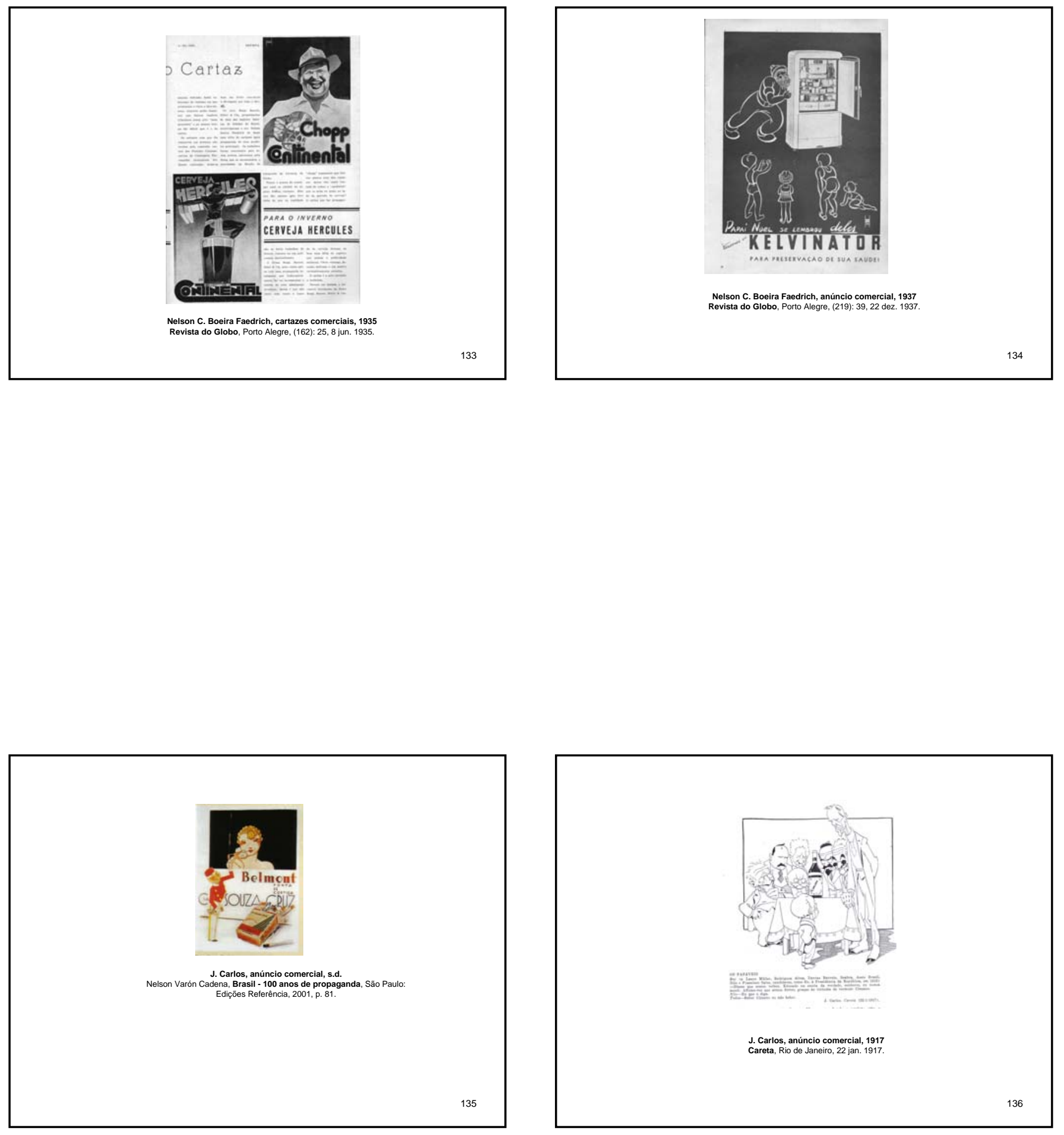

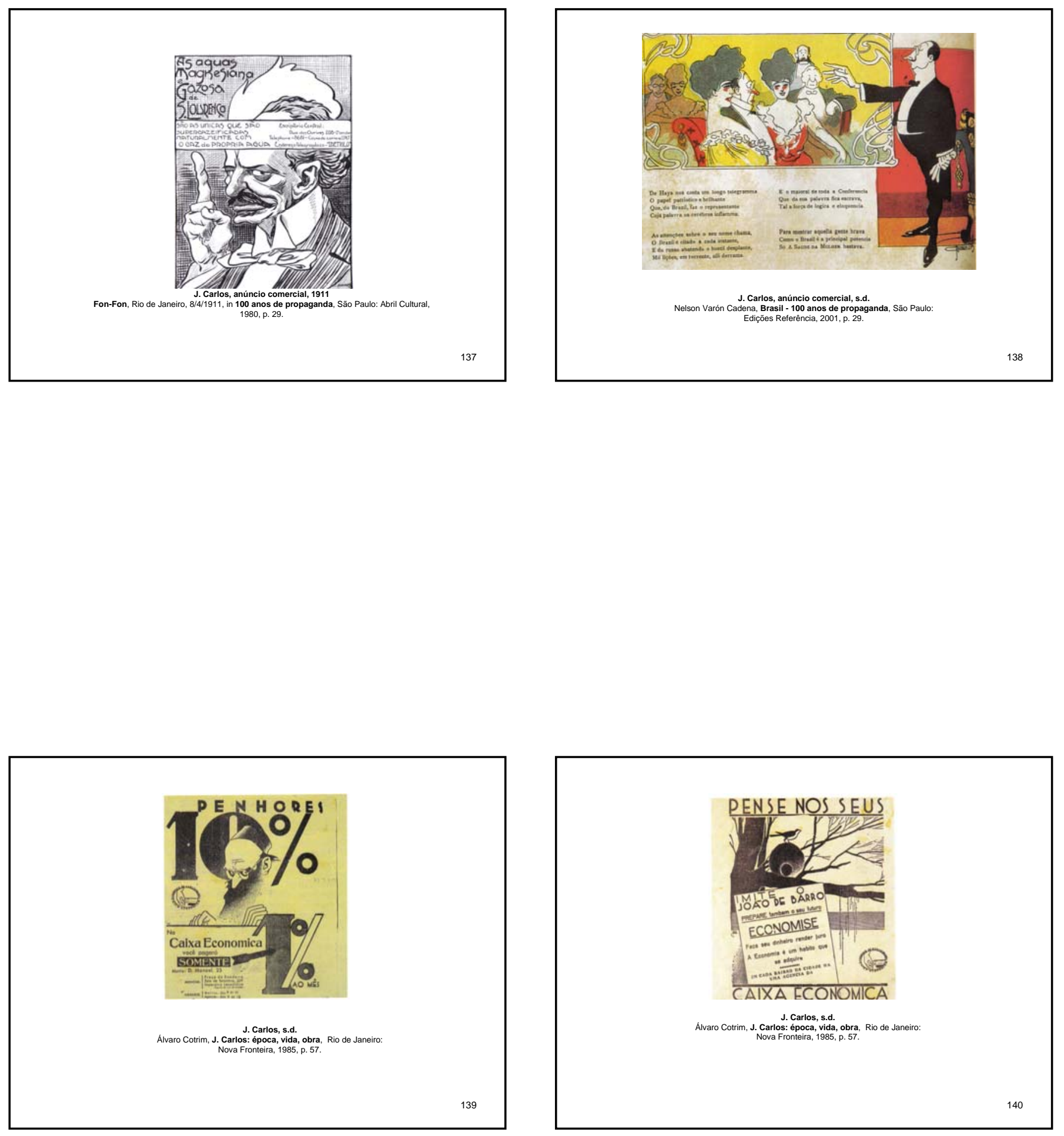

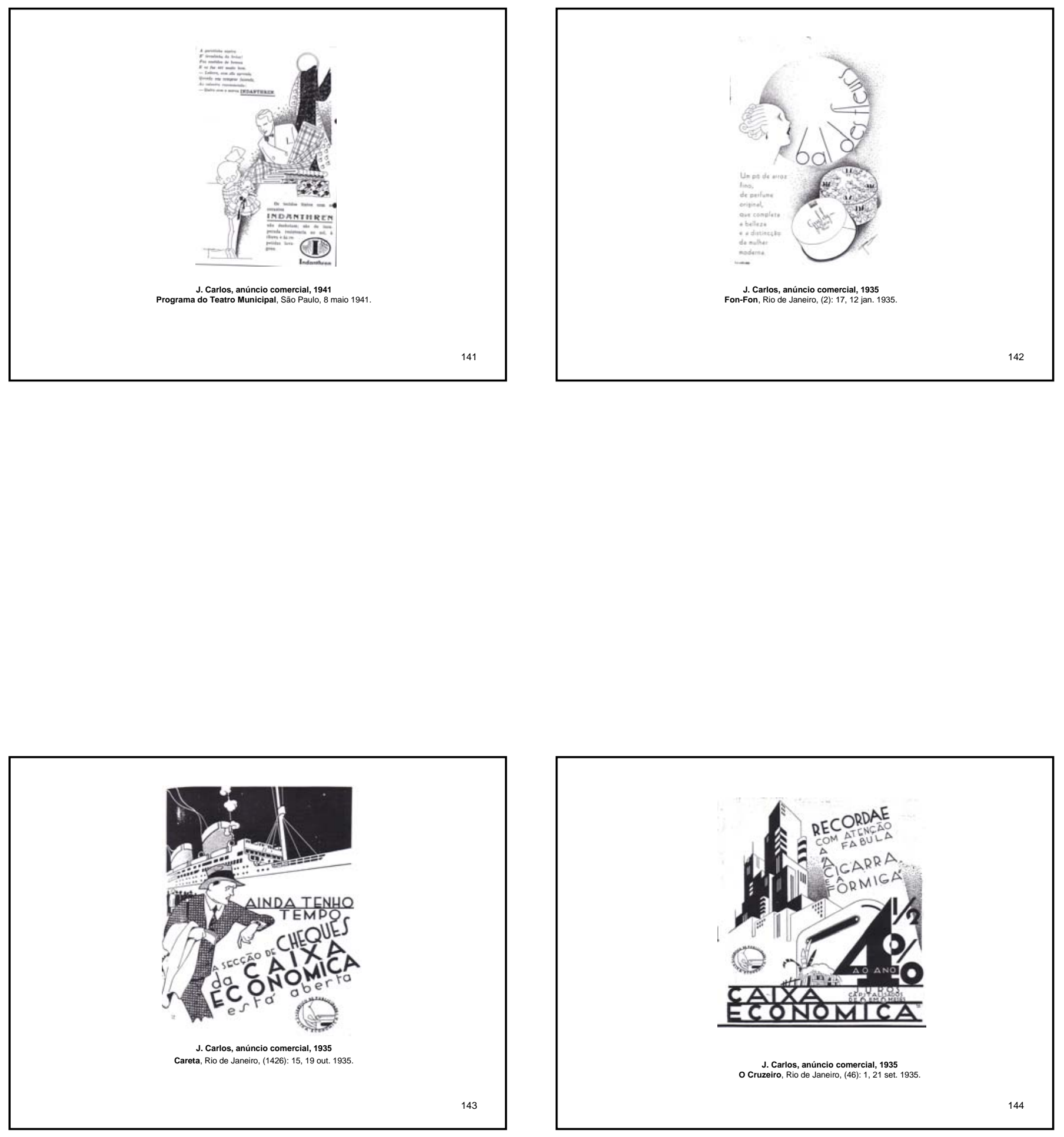

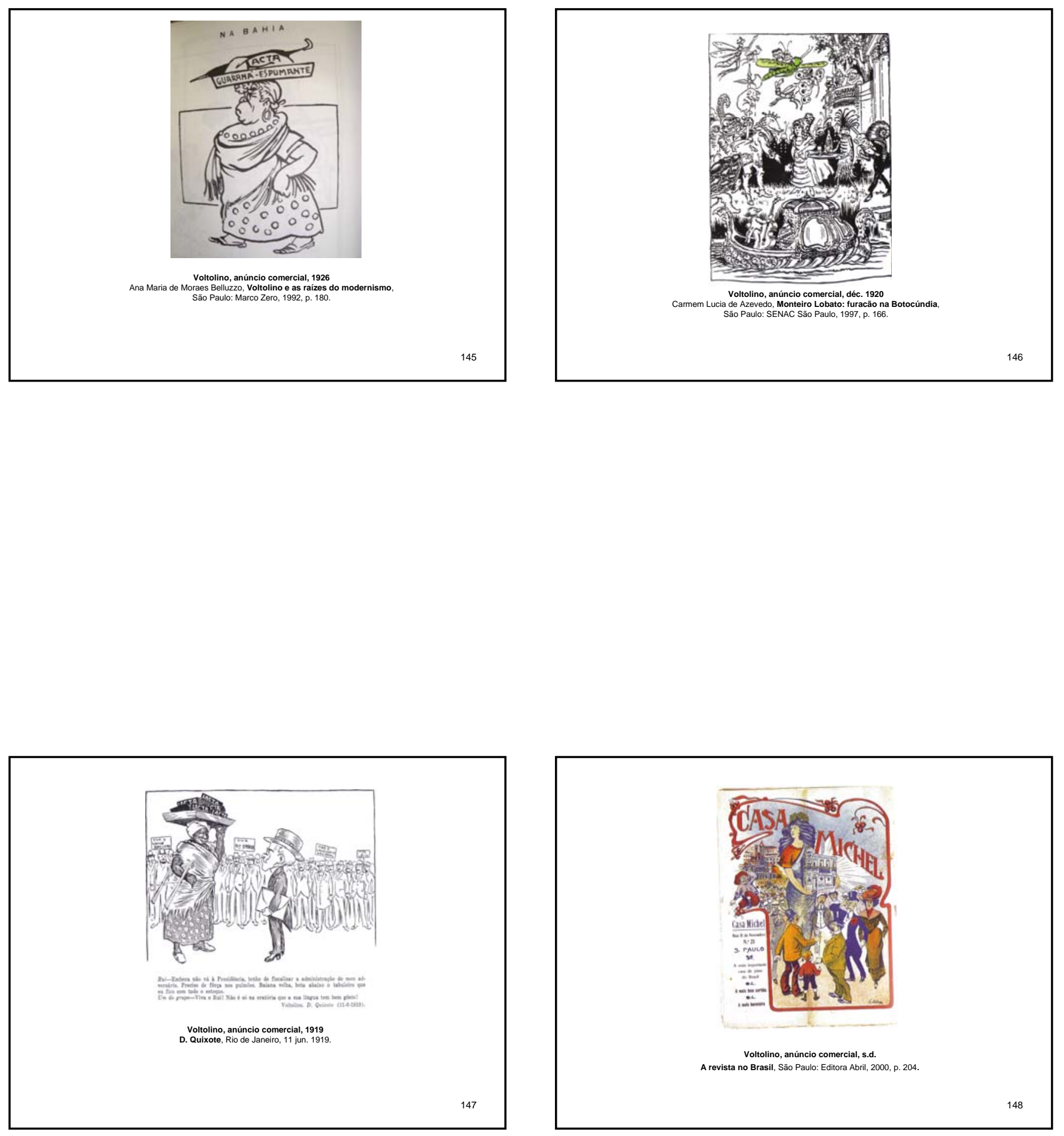

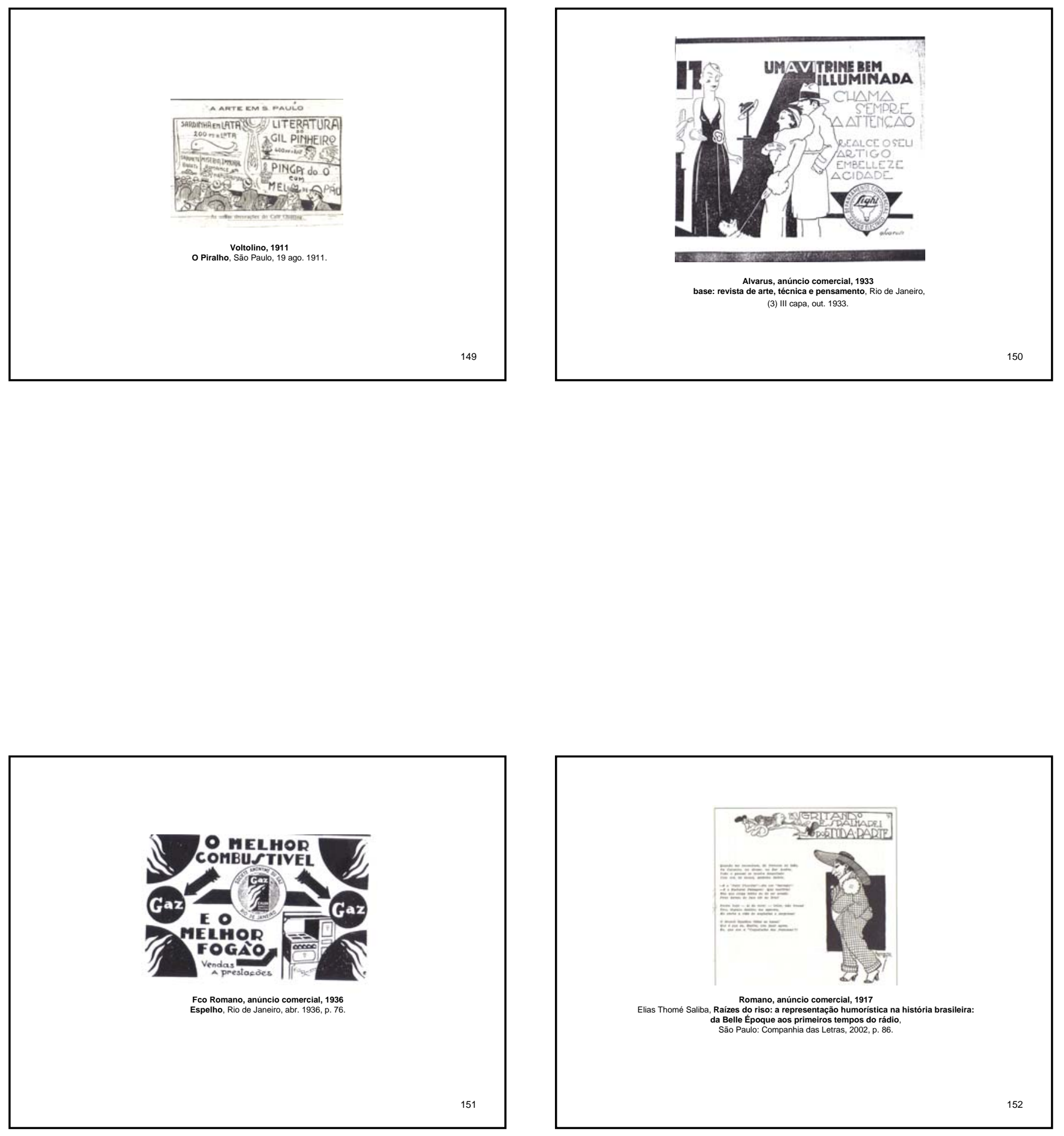

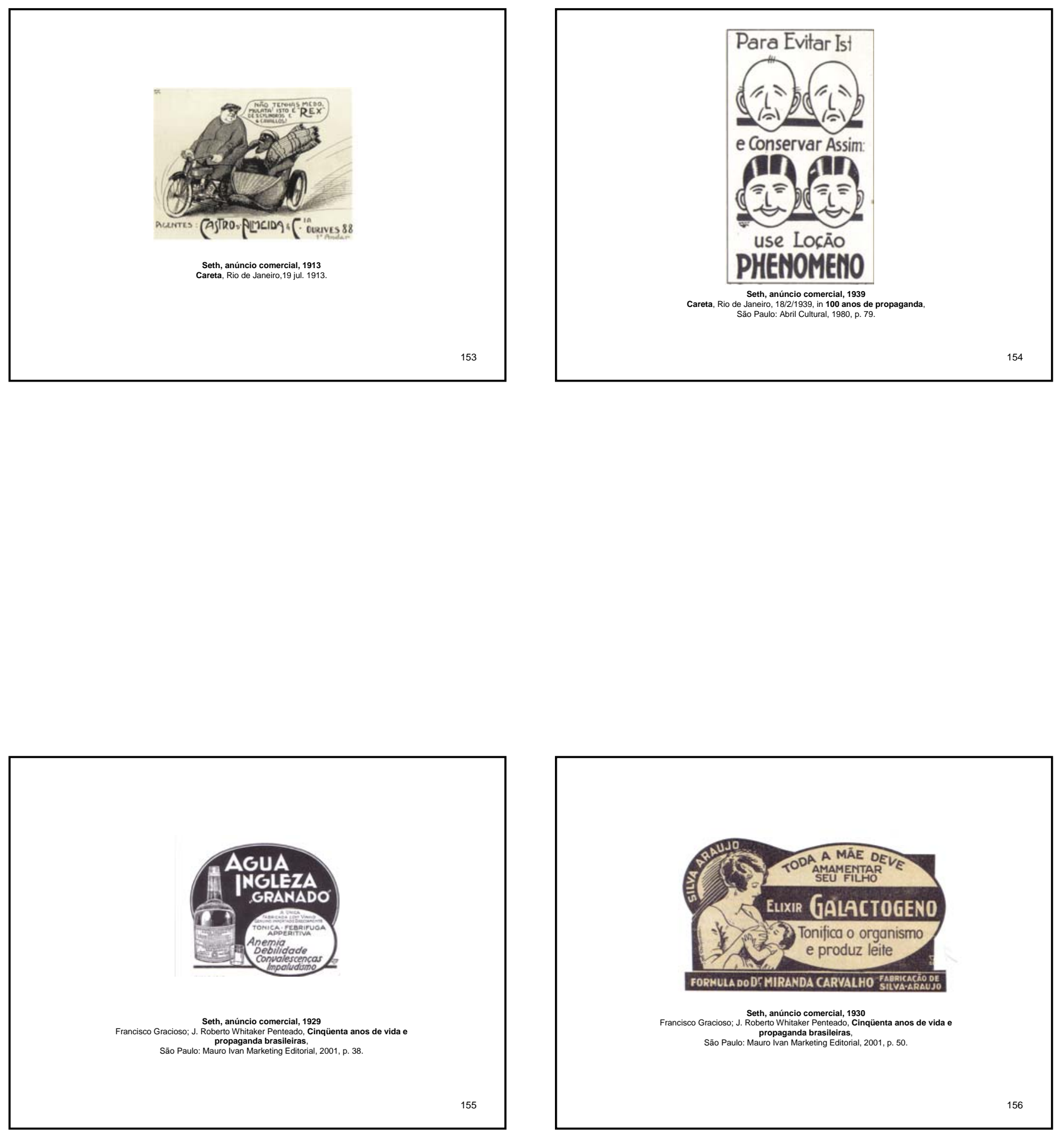

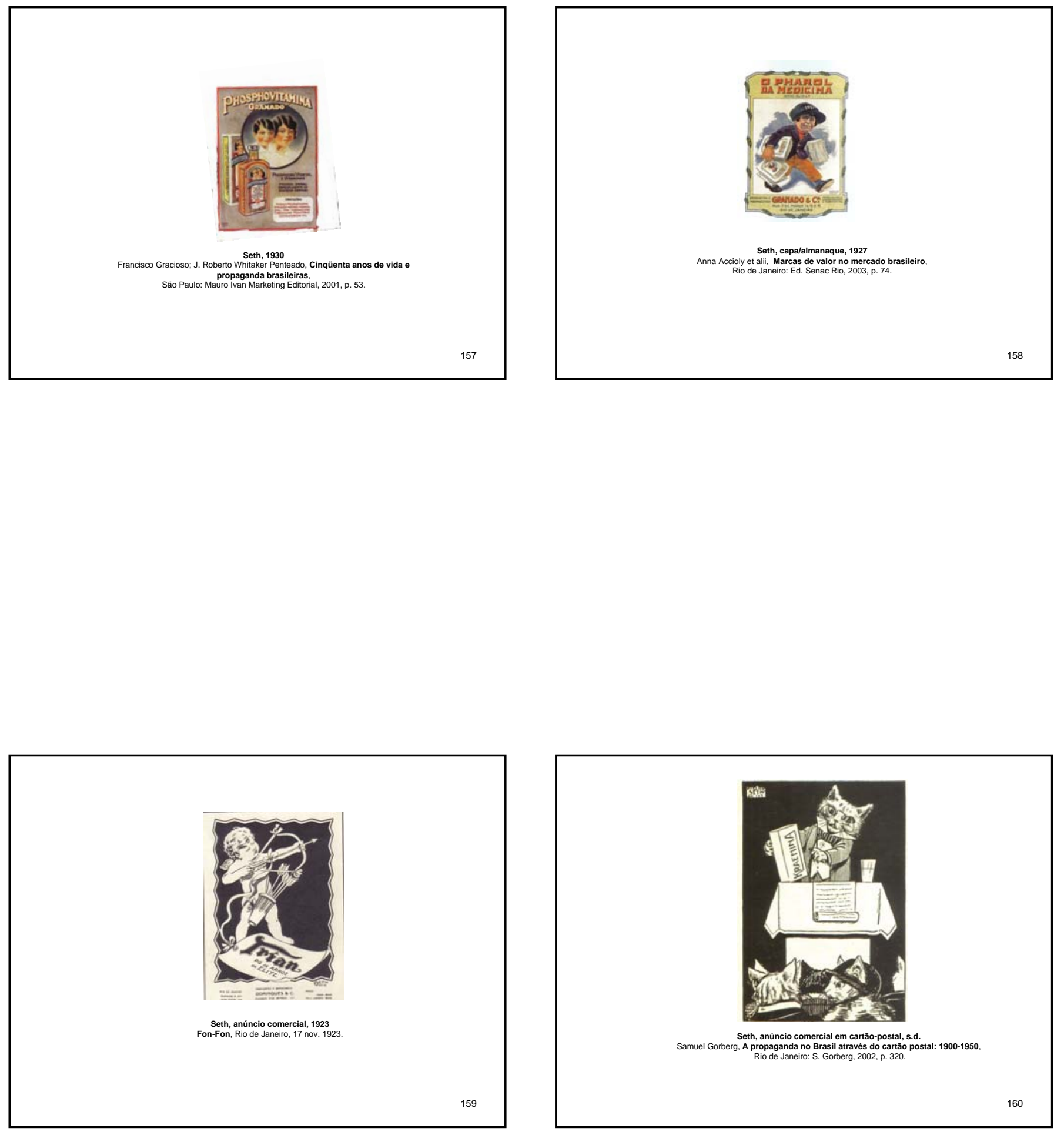

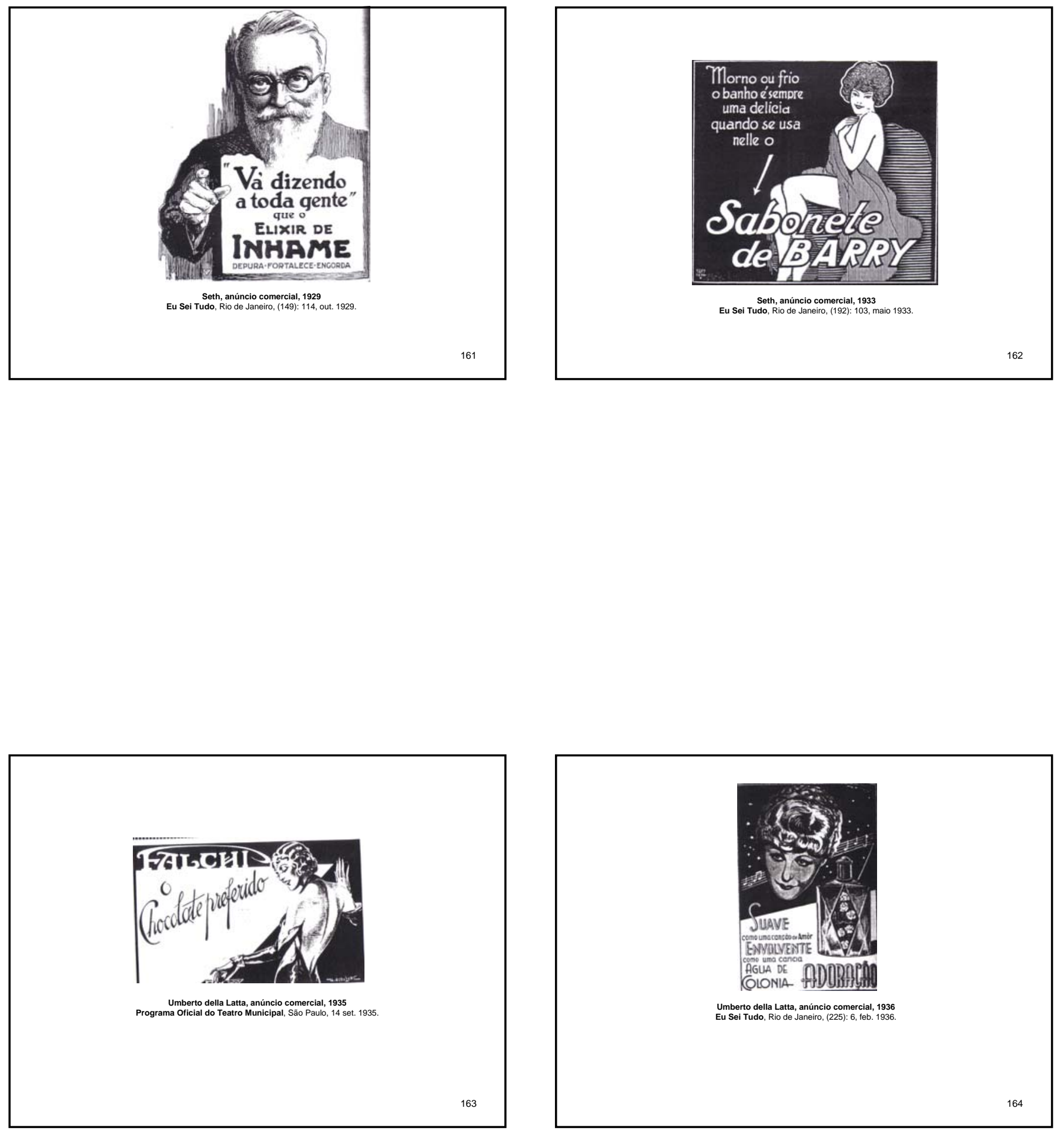

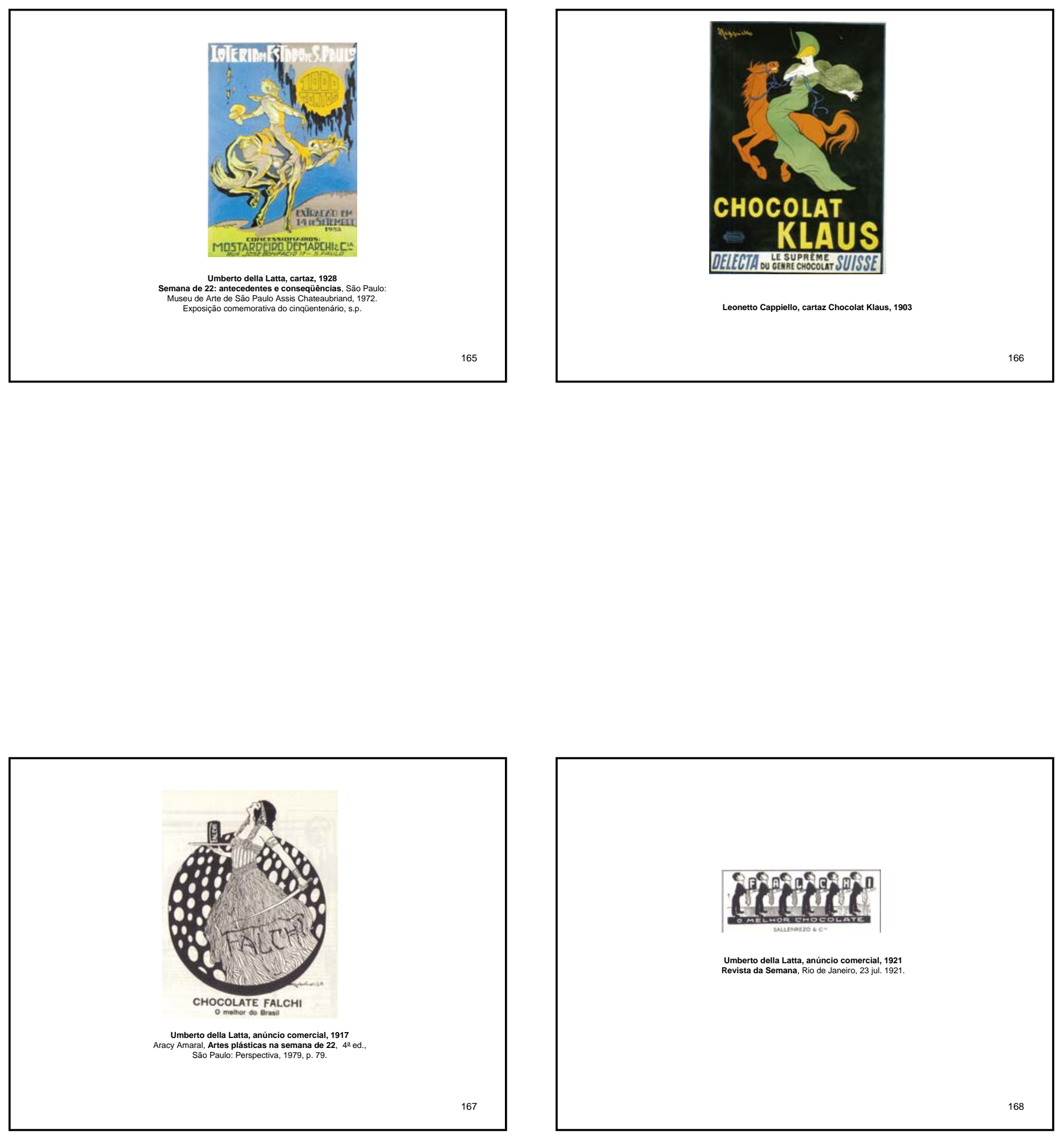

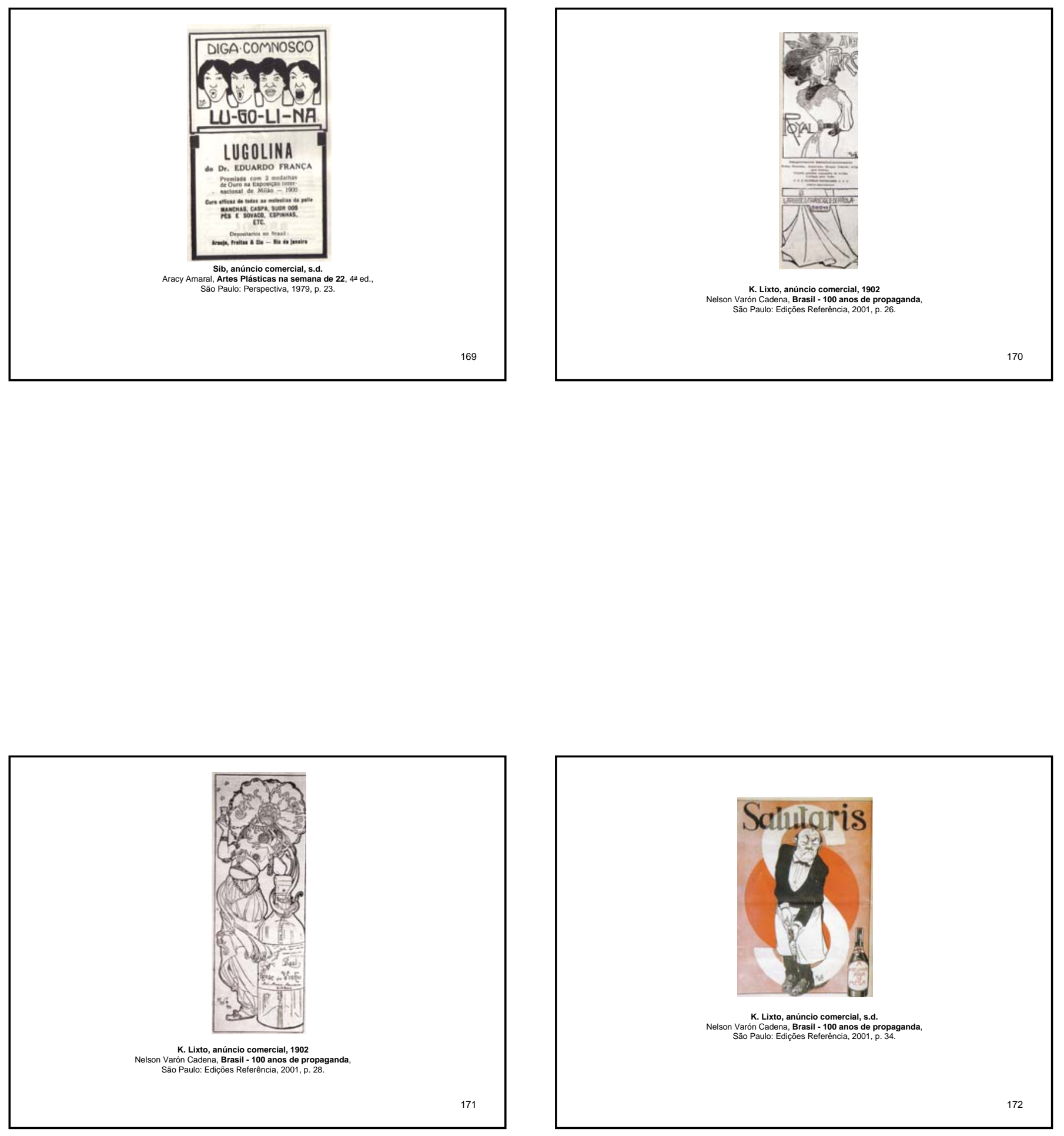

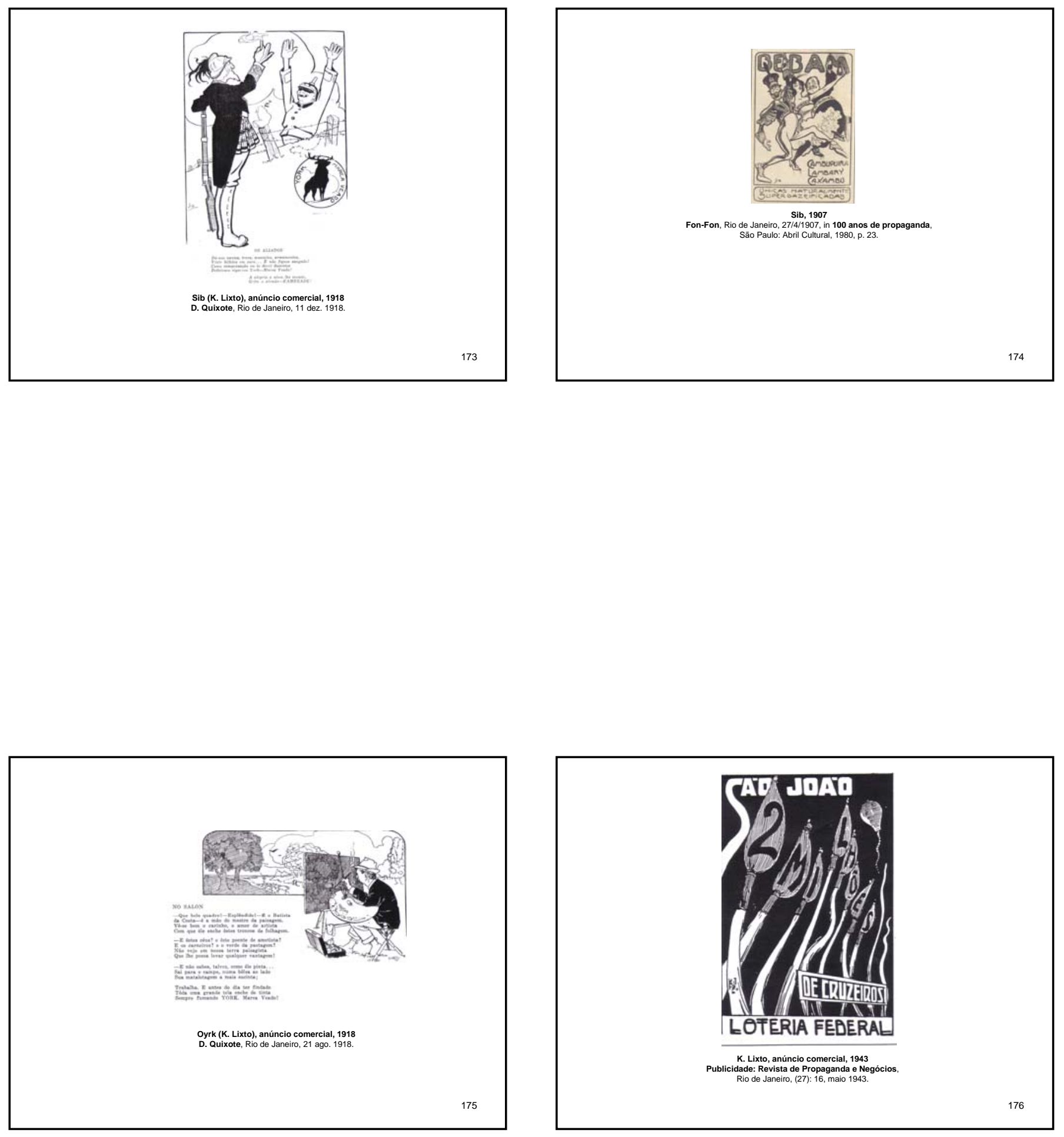

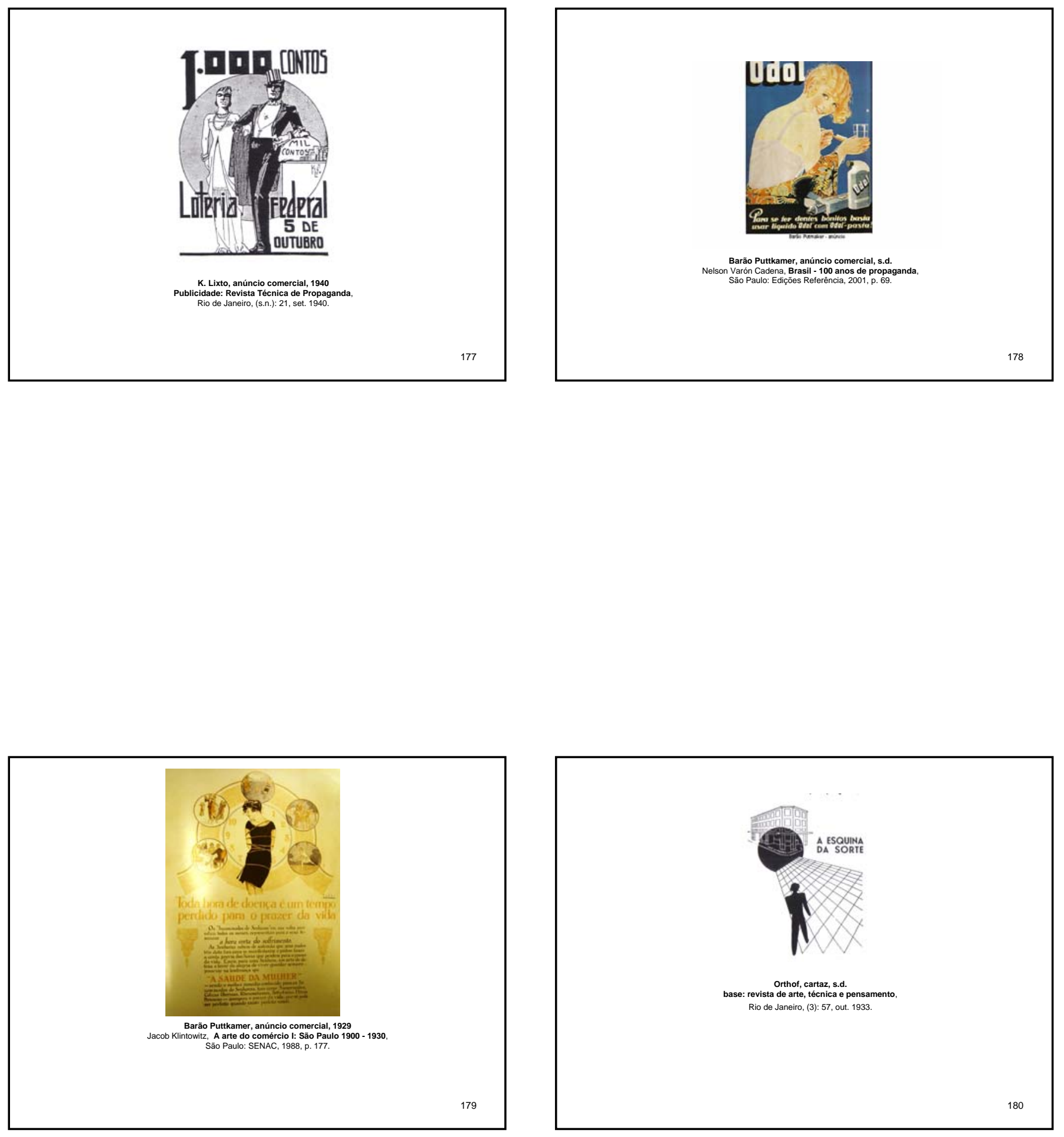

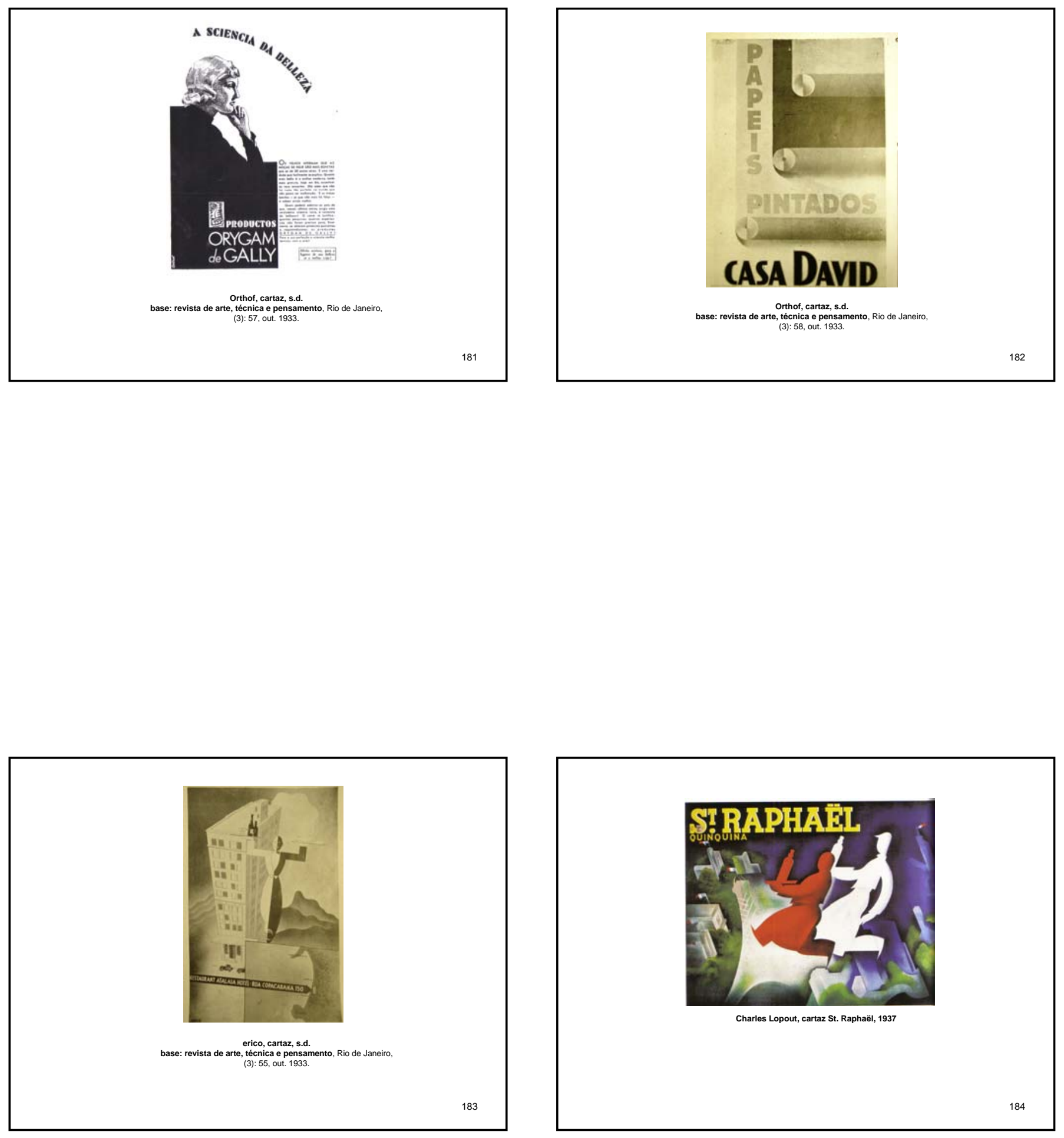

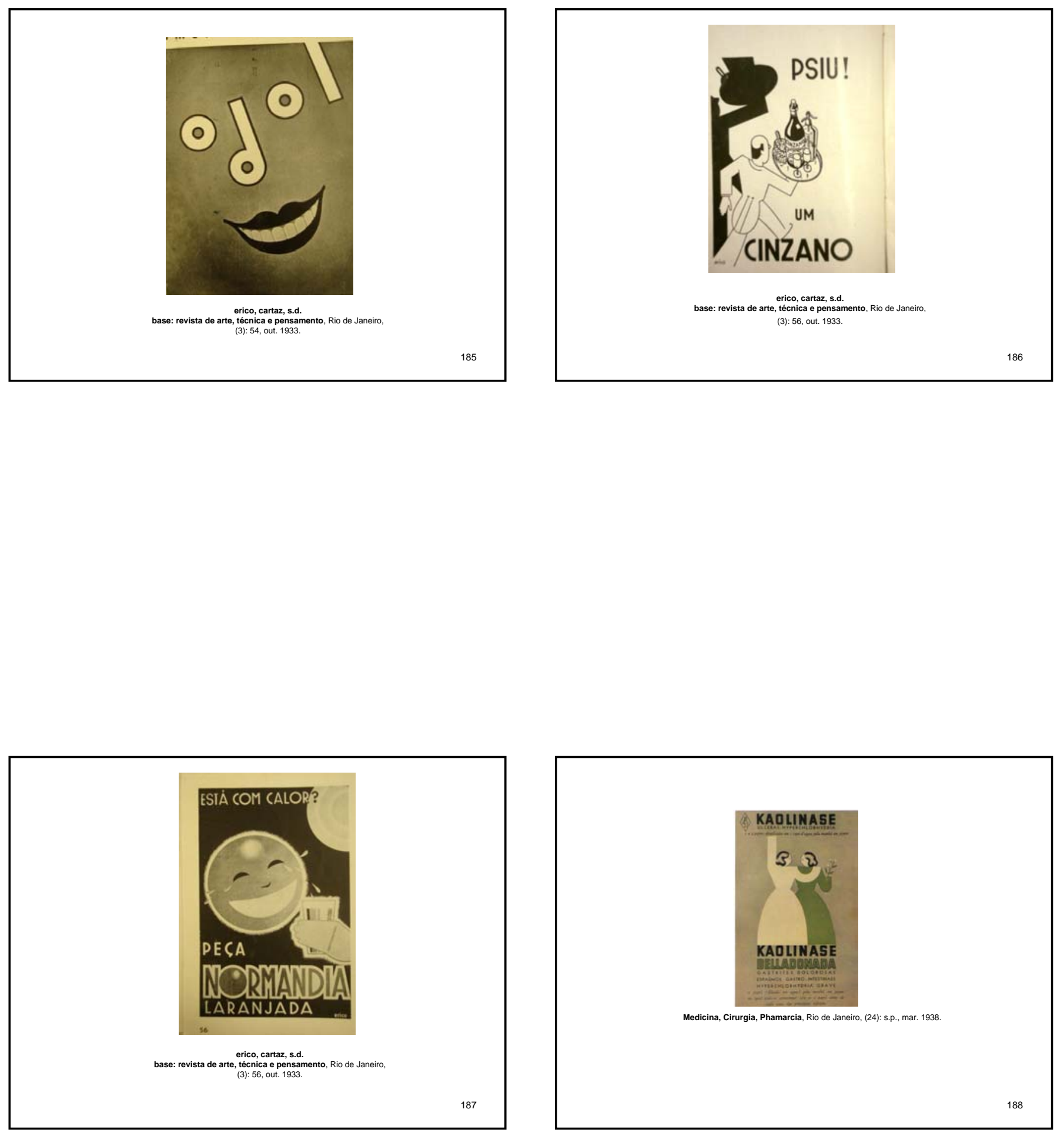

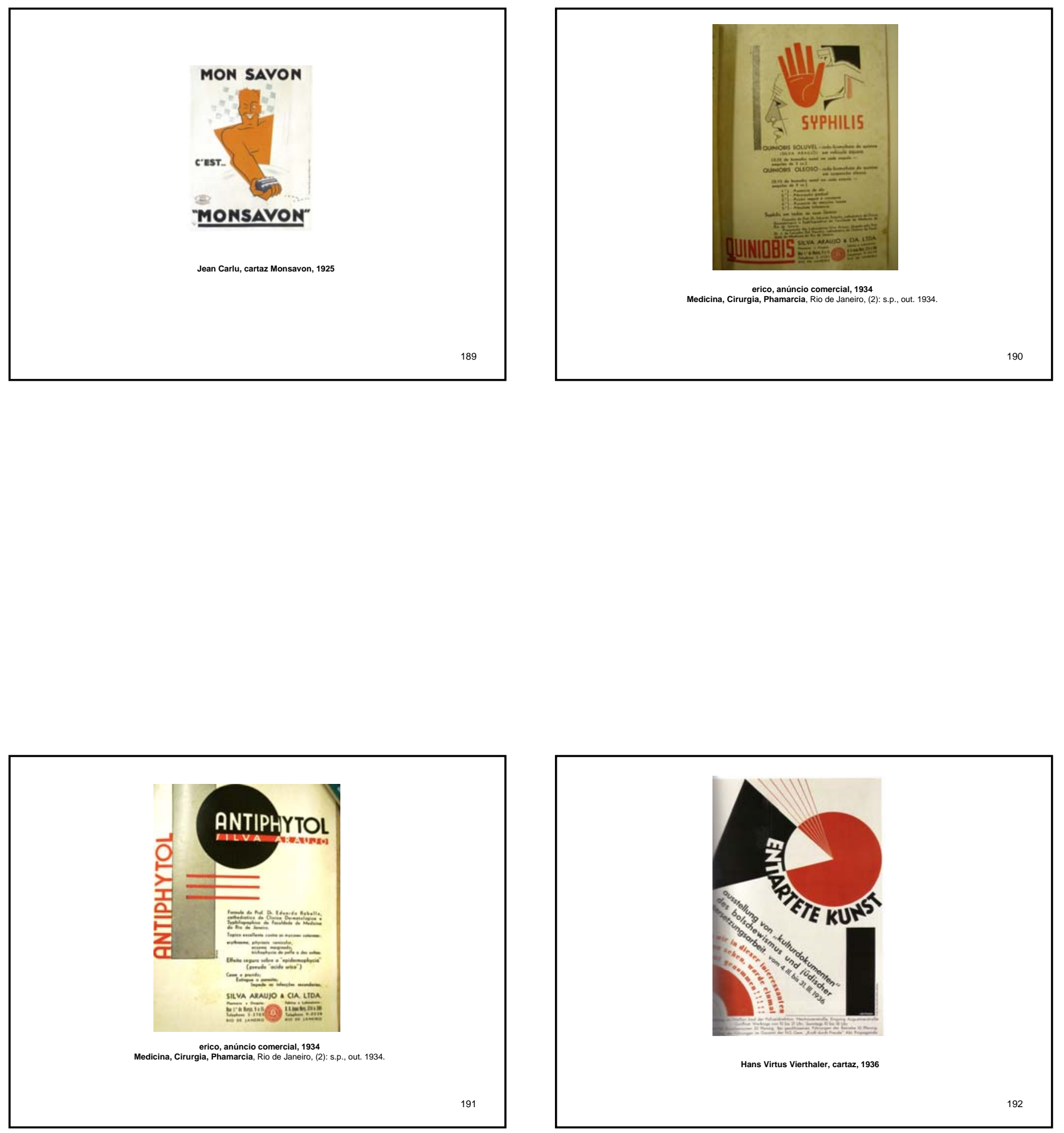

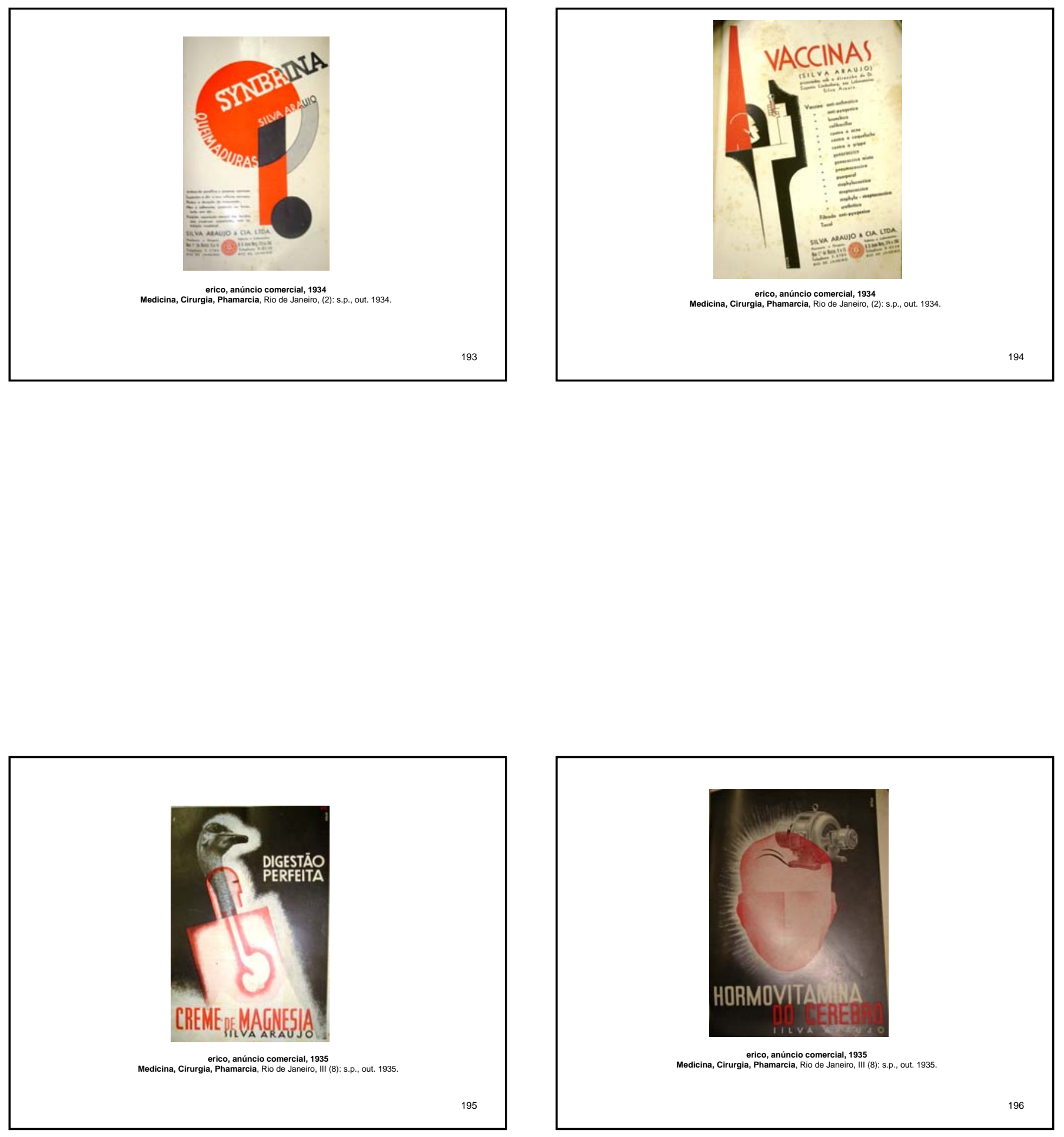

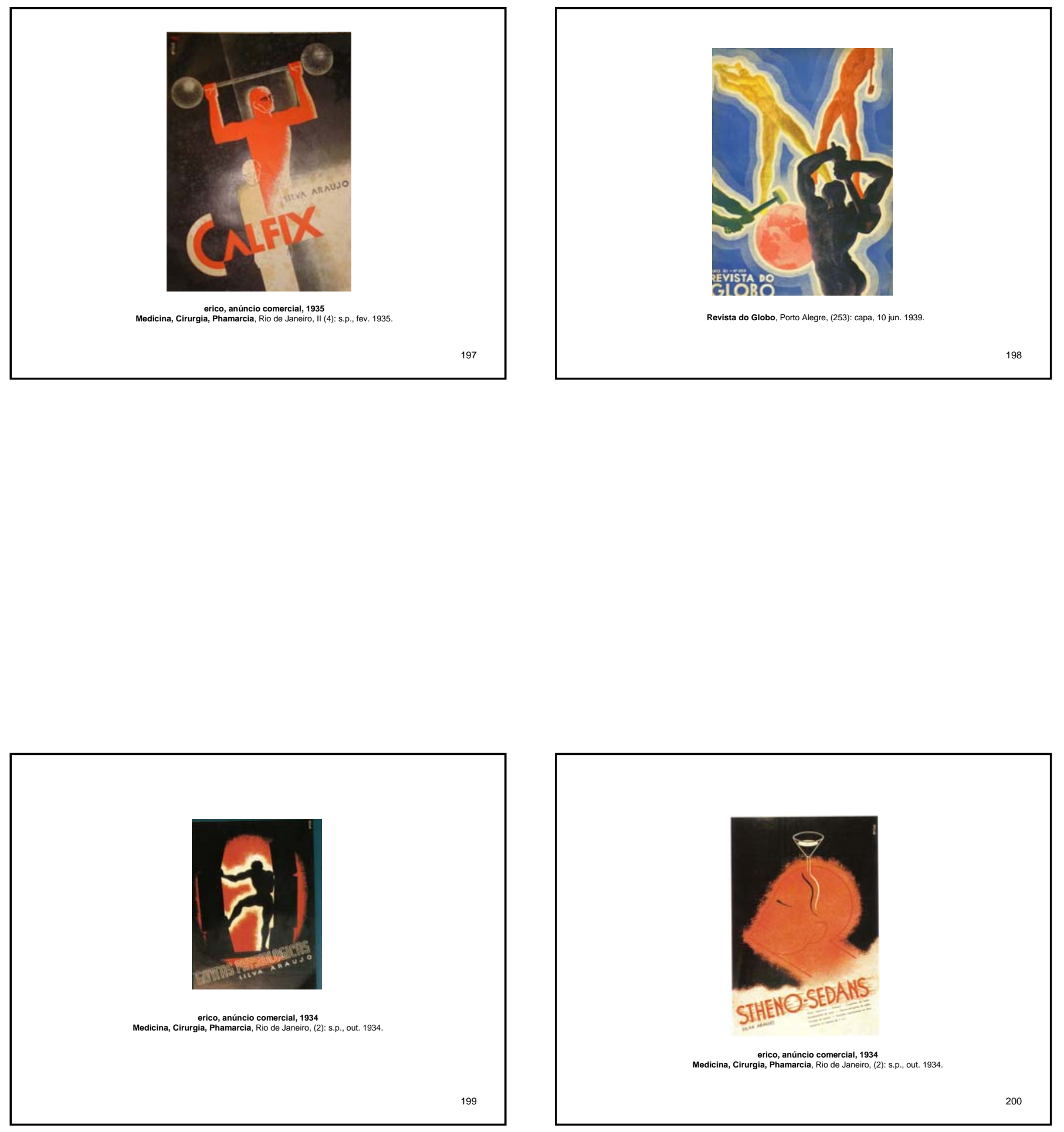

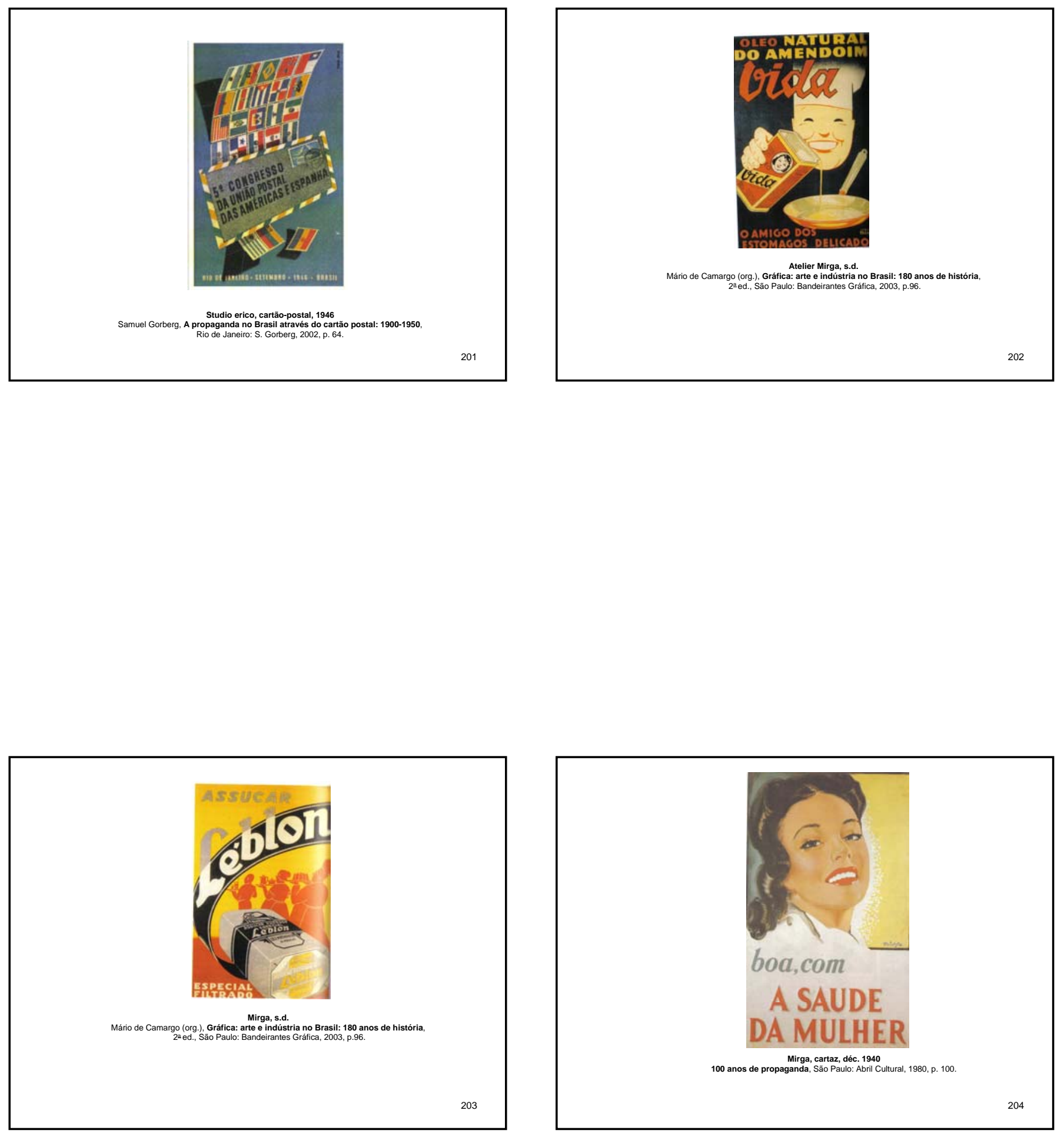

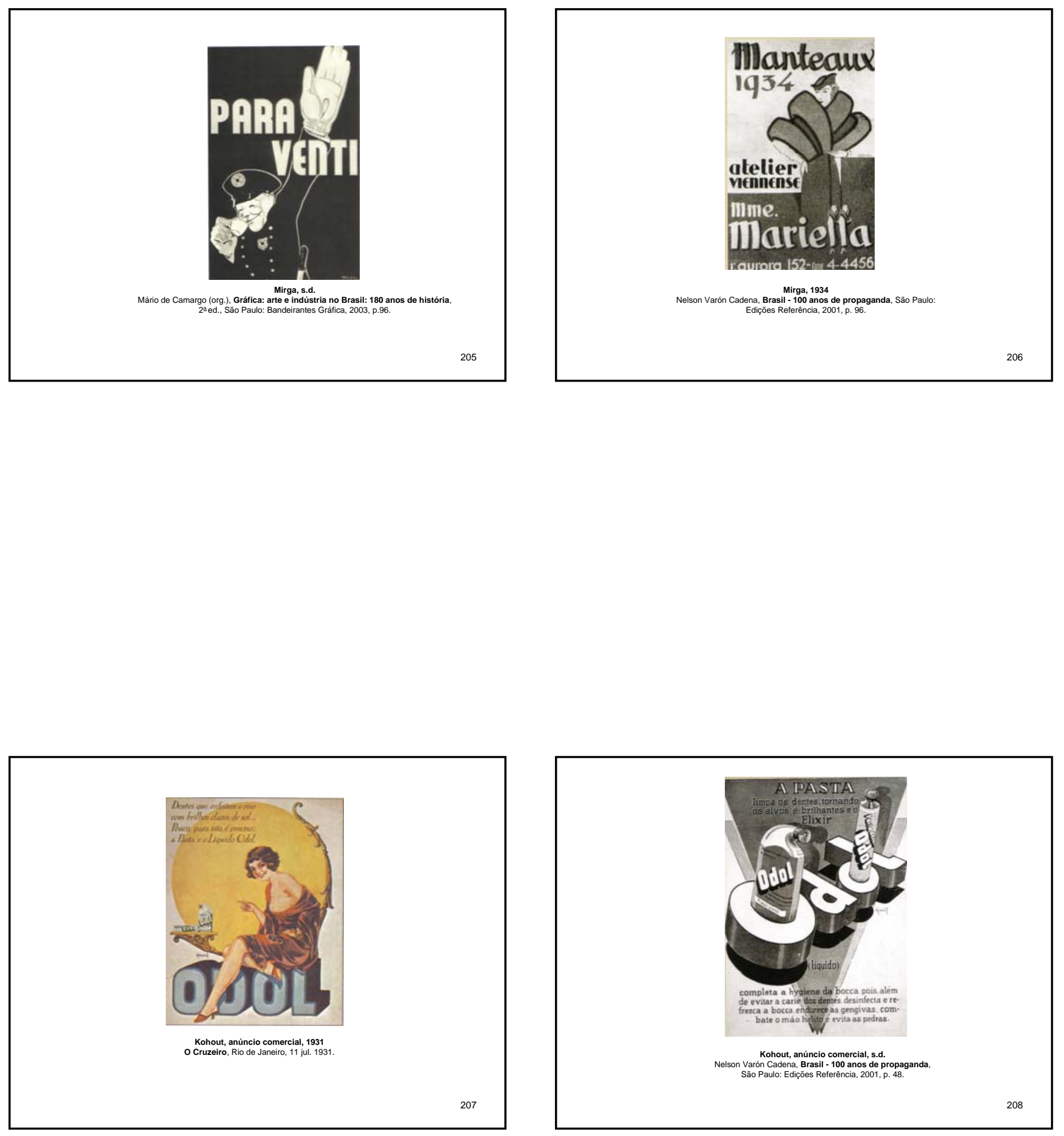

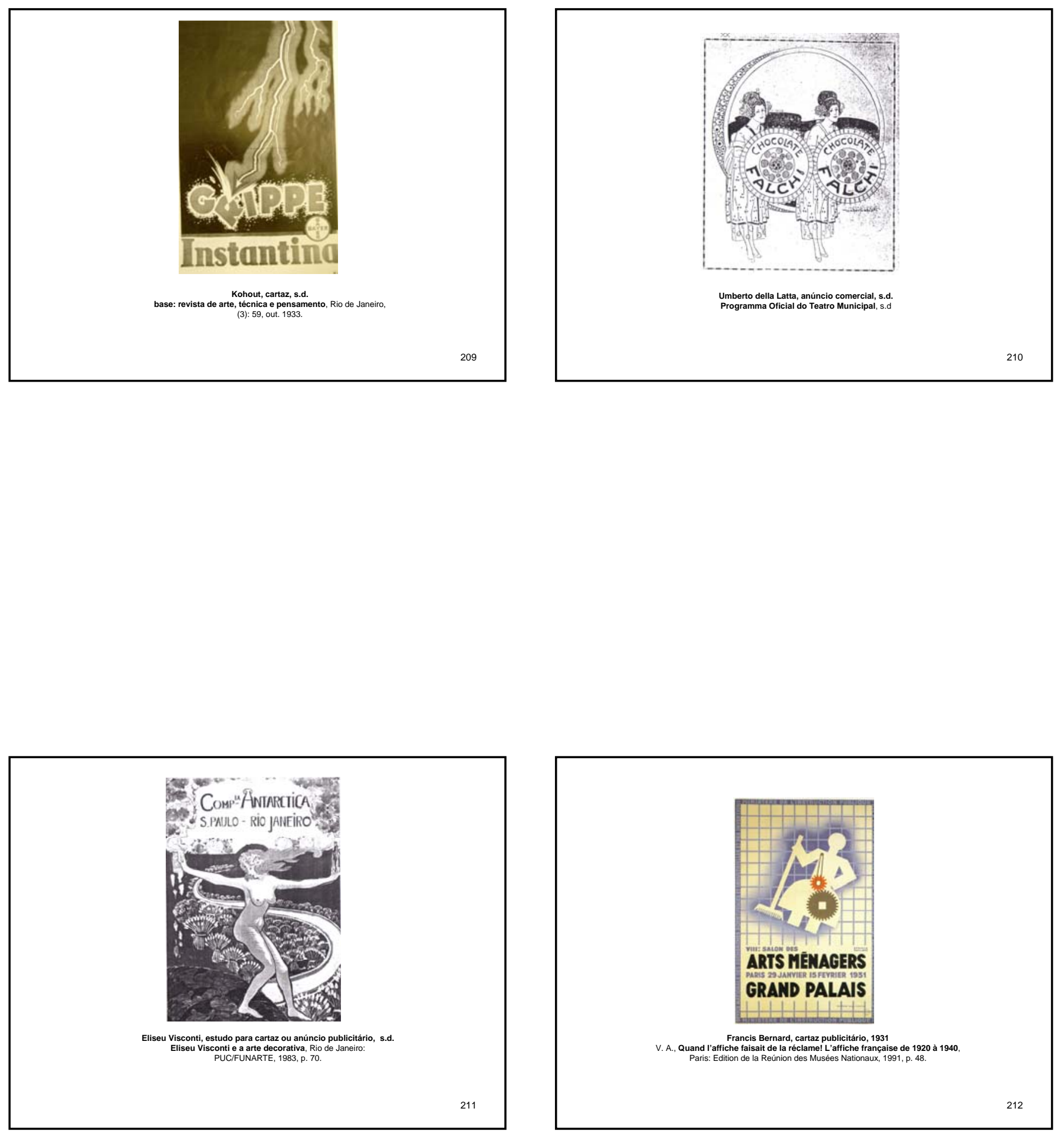

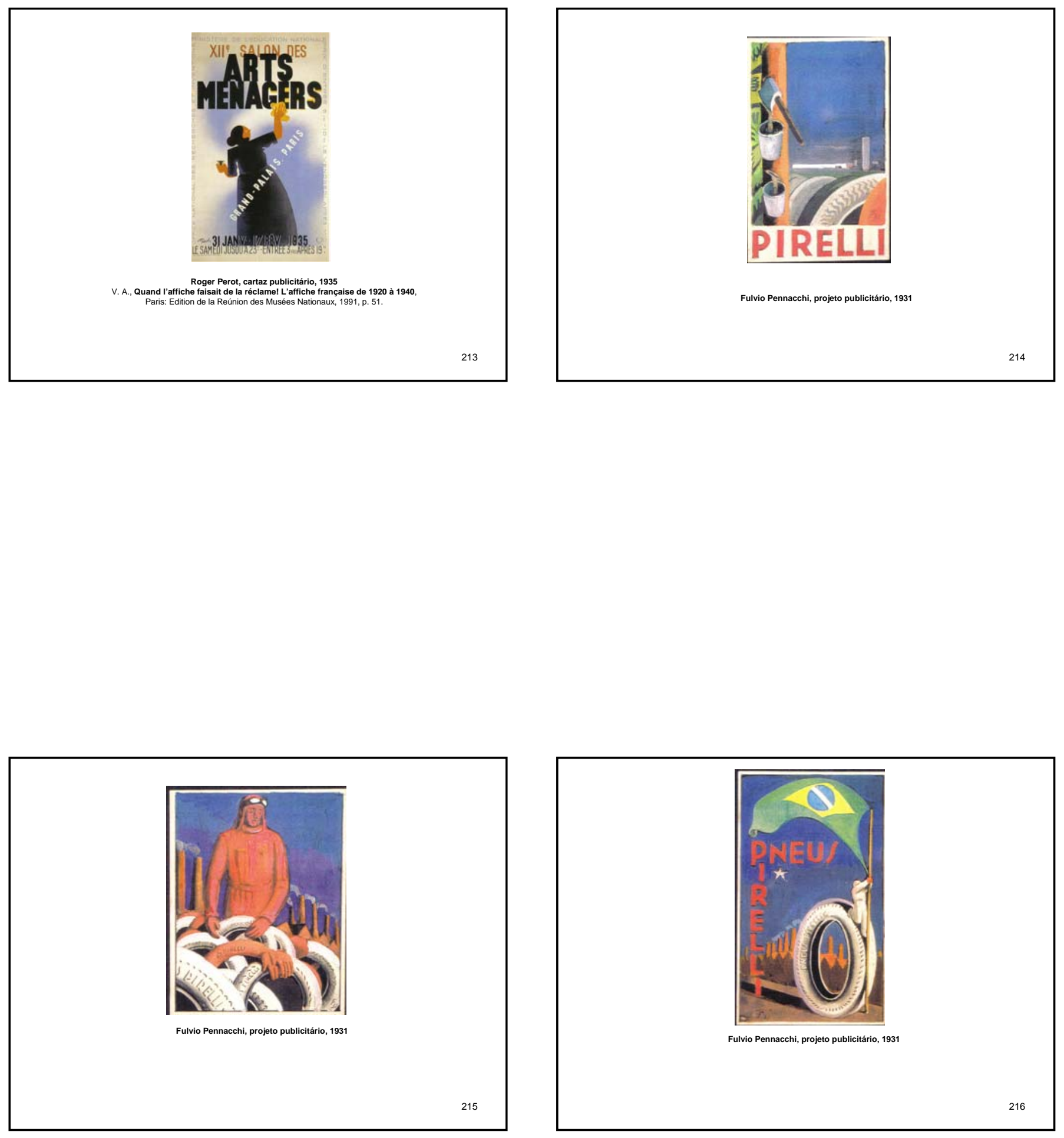


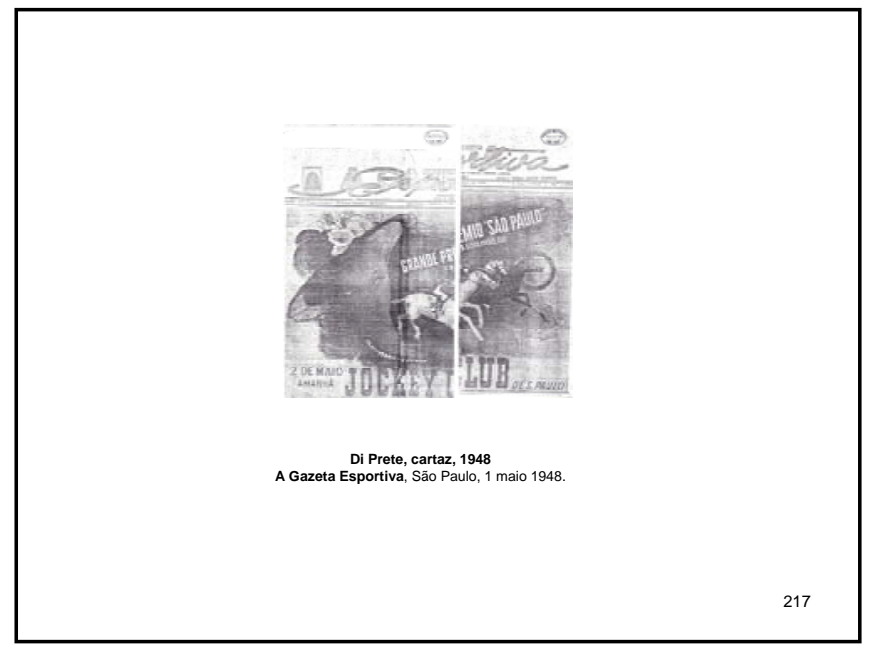

